
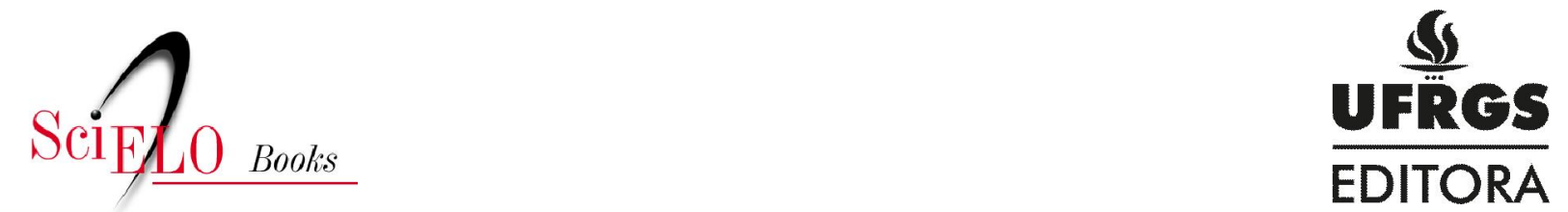

\title{
A pluriatividade na agricultura familiar
}

\author{
Sergio Schneider
}

SciELO Books / SciELO Livros / SciELO Libros

SCHNEIDER, S. A pluriatividade na agricultura familiar [online]. 2nd ed. Porto Alegre: Editora da UFRGS, 2003. Estudos Rurais series, 252 p. ISBN 978-85-386-0389-4. Available from doi: 10.7476/9788538603894. Also available in ePUB from: http://books.scielo.org/id/b7spy/epub/schneider-9788538603894.epub.

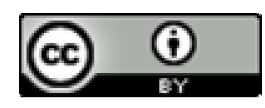

All the contents of this work, except where otherwise noted, is licensed under a Creative Commons Attribution 4.0 International license.

Todo o conteúdo deste trabalho, exceto quando houver ressalva, é publicado sob a licença Creative Commons Atribição $\underline{4.0}$.

Todo el contenido de esta obra, excepto donde se indique lo contrario, está bajo licencia de la licencia $\underline{\text { Creative Commons }}$ $\underline{\text { Reconocimento 4.0. }}$. 
A Pluriatividade

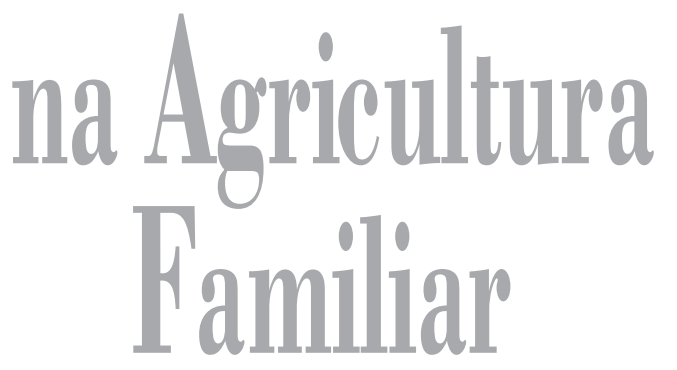




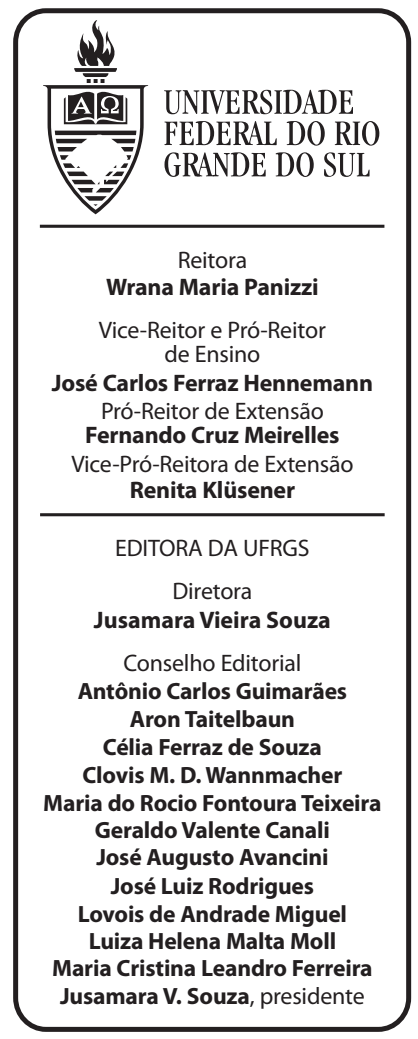


A Pluriatividade

na Agricultura Familiar

Sergio Schneider

Segunda Edição 
(C) dos autores

$1^{\mathrm{a}}$ edição: 2003

Direitos reservados desta edição:

Universidade Federal do Rio Grande do Sul

\section{Capa: Carla M. Luzzatto}

Ilustração da capa: Flávio Scholles, A colheita, 1999. Coleção do artista.

Revisão: Luciane Leipnitz

Editoração eletrônica: Fernando Piccinini Schmitt

Tales Gubes Vaz

Sergio Schneider é professor de Sociologia no Departamento de Sociologia da Universidade Federal do Rio Grande do Sul e membro dos programas de Pós-Graduação em Sociologia (PPGS) e em Desenvolvimento Rural (PGDR), bacharel e licenciado em Ciências Sociais, em 1990, pela UFRGS, mestre em Sociologia, em 1994, pela Unicamp e doutor em Sociologia, em 1999, pela UFRGS, é pós-doutorado em Planejamento Regional e Urbano, 2007-2008, pelo CPAN da Cardiff University/UK.

\section{S359p Schneider, Sergio}

A pluriatividade na agricultura familiar / Sergio Schneider. - 2. ed. - Porto Alegre: Editora da UFRGS, 2009.

258 p.; il.; $16 \times 23 \mathrm{~cm}$

(Série Estudos Rurais)

Inclui referências.

Inclui lista de siglas e abreviaturas.

Inclui gráficos, quadros e tabelas.

1. Sociologia. 2. Sociologia rural. 3. Agricultura. 4. Agricultura familiar - Produção agrícola - Brasil. 5. Economia agrícola. 6. Pluriatividade. 7. Teoria social - Capitalismo - Agricultura familiar. 8. Mercado de trabalho rural. I. Schneider, Sergio. II. Título. III. Série.

CDU 301.35:613.115

CIP-Brasil. Dados Internacionais de Catalogação na Publicação.

(Ana Lucia Wagner - Bibliotecária responsável CRB10/1396)

ISBN 978-85-386-0040-4 
Este livro é dedicado aos meus avós maternos, Edmundo Becker e Paulina Agnes Becker (in memorium), que viveram como colonos simples, honestos e muito felizes, ensinando-me que o respeito e a humildade são valores universais, que valem tanto em Picada dos Nabos como em Paris.

Para Camila Elis e Martina Louise, minhas filhas. 


\section{Agradecimentos}

No momento da primeira reedição deste livro, gostaria de aproveitar a oportunidade para reparar um esquecimento que, desde a sua publicação, não me saiu da cabeça: preciso agradecer e reconhecer a ajuda que recebi de colegas, amigos e instituições! Embora seja uma versão bastante modificada, a base deste livro ainda é a tese de doutorado defendida em 1999 no Programa de Pós-Graduação em Sociologia da UFRGS, que me acolheu como aluno da primeira turma do Curso de Doutorado.

Inicialmente, dedico um agradecimento formal a CAPES, que me concedeu bolsa entre agosto de 1994 e julho de 1995, e ao CNPq, que financiou meu estágio no Laboratoire Dynamiques Sociales et Recompositions des Espaces na França, entre setembro de 1997 e abril de 1998, com uma bolsa. Também sou grato aos auxílios financeiros que obtive da FAPERGS, da Fundação FORD (Concurso FORD/ANPOCS, 1997) e da Pró-Reitoria de Pesquisa da UFRGS, que muito me auxiliaram nas viagens e pesquisas de campo.

Agradeço ao professor Hugues Lamarche, diretor do LADYSS na Université Paris-X-Nanterre, que me acolheu durante o estágio sanduíche. Na França, também foram importantes as discussões com os professores Afrânio Garcia (EHESS), Bernard Roux (INA/Paris-Grignon), André Brun (INRA/Orléans) e com Ademir Cazella. No Brasil, sou agradecido ao professor José Graziano da Silva e a toda equipe do Projeto Rurbano, especialmente as colegas Mauro Del Grossi, Lauro Mattei, Flávio Sacco dos Anjos e Marcelino de Souza. Agradeço a Cláudia Schimitt, colega e amiga de longa data, e ao pintor Flávio Scholles, conterrâneo de Dois Irmãos, cuja pintura ilustra a capa do livro.

Um reconhecimento especial dedico aos auxiliares de pesquisa que ajudaram na coleta de dados, na transcrição de materiais, na organização do banco de dados e na revisão final do livro. Aos agricultores e suas famílias, que permitiram acesso a informações sobre sua forma de viver a vida, só tenho a dizer: muito obrigado! 
Entre todos, a Zander Navarro ofereço um agradecimento especial, não apenas por ter sido meu orientador durante o doutoramento mas, sobretudo, por ser um colega respeitoso, um amigo valoroso, um professor perfeccionista e inteligente e um ser humano íntegro e de extraordinária sensibilidade. Ao longo de 20 anos de convivência tenho sido agraciado com sua companhia e me beneficiado de sua generosidade, o que faz do meu local de trabalho, a UFRGS, um privilegiado campo de renovação do saber. 


\section{Prefácio}

Nos últimos 5 anos, a Secretaria da Agricultura Familiar - Ministério do Desenvolvimento Agrário - tem melhorado e, principalmente, criado, várias políticas públicas que podem beneficiar os 4,1 milhões de estabelecimentos familiares em nosso país. São políticas de crédito, seguros (risco climático e preços), extensão rural, acesso a mercados, inovação tecnológica, diversificação produtiva, e outras. Isto se deve ao claro entendimento que nenhum país deu o "salto para o futuro" sem o apoio e fortalecimento da sua classe média rural. Trata-se do conhecido dilema do crescimento com distribuição.

Historicamente e com fortes entrelaçamentos aos processos de criação e execução das políticas públicas, muitos intelectuais brasileiros têm chamado a atenção para a insuficiência, embora importantes, da mera existência das políticas agrícolas clássicas. Afirmam a necessidade da articulação destas em favor de uma conceituação mais ampla do desenvolvimento rural, onde as responsabilidades ambientais, econômicas, sociais e culturais são necessárias e devem estar imputadas nas práticas rurais. Trata-se da responsabilização de uma agricultura pluriativa e versátil no bojo do desenvolvimento rural sustentável.

Assim entendido, os pequenos e médios empreendimentos familiares rurais têm uma vantagem comparativa nesta nova agricultura de futuro. A pluriatividade na agricultura familiar é uma característica historicamente construída e apresenta-se na essência dos seus sistemas de produção. Ao longo das últimas quatro décadas as famílias rurais construíram dinâmicas diferenciadas para se manterem em seus estabelecimentos, fazendo frente ao modelo de produção estabelecido pela chamada agricultura moderna.

A diversificação da produção e noções claras de iniciativas pluriativas são fatores de substantivo valor para o alcance do desenvolvimento sustentável. A disponibilização estável e a articulação de políticas públicas jogam importante fator na implementação destes projetos. 
A leitura desta obra possibilitará estabelecer inúmeras reflexões e debates à cerca das alternativas de vida no rural, com cidadania, saúde, renda e sustentabilidade. Boa leitura!

Adoniram Sanches Peraci

Secretário de Agricultura Familiar do Ministério do Desenvolvimento Agrário 


\section{Sumário}

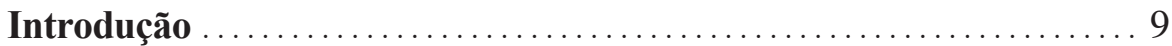

\section{Capítulo 1}

Teoria social, capitalismo e agricultura familiar ............. 21

1.1 Teorias da agricultura familiar ........................ 24

1.2 O debate brasileiro sobre a agricultura familiar ............ 28

1.3 A contribuição da Sociologia da Agricultura ................ 42

1.4 Análises teóricas recentes sobre a agricultura familiar:

O modelo de Lamarche e o de Gasson e Errignton ........... 62

1.5 Críticas e limites das abordagens neomarxistas sobre a agricultura familiar $\ldots \ldots \ldots \ldots \ldots \ldots \ldots \ldots \ldots, 68$

\section{Capítulo 2}

Agricultura familiar e pluriatividade $\ldots \ldots \ldots \ldots \ldots \ldots \ldots \ldots \ldots$

2.1 Da agricultura de tempo parcial à pluriatividade ............ 74

2.2 Teoria social e pluriatividade: uma revisão do debate recente. ... 80

2.3 Agricultura familiar e pluriatividade: elementos teóricos ...... 91

2.4. Esboço de uma proposta teórica para o estudo da pluriatividade.. 96

2.5 A família pluriativa: em busca de uma unidade de análise ..... 100

\section{Capítulo 3}

As transformações estruturais da agricultura e os impactos sobre os mercados de trabalho rurais: a emergência das ocupações não-agrícolas

3.1 Tendências recentes das ocupações agrícolas e não-agrícolas nos países desenvolvidos .................. 116

3.2 A evolução das ocupações rurais não-agrícolas na América Latina . 128

3.3 As ocupações agrícolas e não-agrícolas no Brasil:

o Projeto Rurbano 


\section{Capítulo 4}

Pluriatividade e agricultura familiar no sul do Brasil:

Rio Grande do Sul e Santa Catarina em perspectiva comparada ..... 143

4.1 A dinâmica das atividades agrícolas e não-agrícolas no Rio Grande do Sul

4.2 A dinâmica das atividades agrícolas e não-agrícolas em Santa Catarina

4.3 Agricultura familiar, descentralização industrial e pluriatividade

4.4 A dinâmica local da pluriatividade:

Padre Eterno Ilges/RS e Vila Itoupava/SC

4.5 O estudo da pluriatividade em perspectiva comparada . ...... 170

4.6 Para uma definição operacional da pluriatividade ........... 173

\section{Capítulo 5}

A pluriatividade como estratégia de reprodução da agricultura familiar

5.1 Pluriatividade e agricultura: acesso à terra, transformações nos processos produtivos e impactos na organização do trabalho familiar

5.2 Mercado de trabalho não-agrícola, pluriatividade e agricultura familiar

5.3 O papel da pluriatividade na reprodução social das famílias rurais: uma comparação entre as rendas agrícolas e não-agrícolas

5.4 Pluriatividade: uma opção individual em busca de um estilo de vida?

Considerações finais

Referências bibliográficas 


\section{Introdução}

Este livro é o resultado de um trabalho de pesquisa que se iniciou em meados da década de 1990, primeiramente confinado a um estudo de caso no Rio Grande do Sul e, depois, estendido à comparação com outro caso no Estado de Santa Catarina. Seu tema, as atividades rurais não-agrícolas e o crescimento da pluriatividade das famílias de agricultores, é relativamente recente na literatura brasileira, tendo gerado, nos últimos anos, uma interessante controvérsia que vem alimentando os debates em eventos científicos e gerando profícuas pesquisas acadêmicas sobre o caráter da ruralidade brasileira. Entre os estudiosos, de um lado, há os que justificam seu desinteresse pelo tema respaldados em argumentos que sustentam que a combinação de múltiplas atividades no seio de uma família de agricultores seria uma característica antiga, praticada desde os tempos do fim do feudalismo, quando passaram a existir as formas familiares autônomas assentadas nas pequenas propriedades de terra, em condições que, mais ou menos, perduram até os dias de hoje. Os proponentes dessa tese argumentam que a novidade da ruralidade brasileira consiste no reconhecimento social e político do chamado "setor de subsistência", formado por milhares de pequenos agricultores que teriam sua origem histórica como remanescentes do regime colonial e do escravismo, não tendo sido eliminados nem mesmo pela industrialização e modernização conservadora da agricultura, que, na década de 1990, foram contemplados com a universalização dos direitos previdenciários. De outro lado, há os que argumentam que a pluriatividade seria uma característica passageira ou transitória, que tenderia a desaparecer na proporção em que avançasse o processo de subordinação da agricultura e do mundo rural à dinâmica urbana e industrial da sociedade contemporânea. Argumentam que, no Brasil, ao contrário do que teria ocorrido na Europa, o recurso das famílias às atividades não-agrícolas representaria a busca de "empregos de refúgio", dada a sua fragilidade social e econômica como agricultores e às melhores condições de remuneração oferecidas pelos setores não-agrícolas. Propugnam, por isto, maior esforço ao fortalecimento das atividades agrícolas como meio de inserção dos pequenos agricultores na economia. 
Mas há também aqueles que se encantaram com as potencialidades da pluriatividade e das atividades não-agrícolas e seu papel no desenvolvimento rural, esquecendo-se de situar os lugares e os contextos em que estes processos puderam emergir e se desenvolver. Em geral, esses analistas cometem o pecado da generalização apressada e da associação sem mediações como o que transcorre nos chamados países capitalistas avançados ou desenvolvidos. Observando certas dinâmicas regionais ou territoriais, muitos pesquisadores acabaram salientando a capacidade empreendedora dos agricultores familiares pluriativos vis-à-vis aos demais.

Neste livro pretende-se contribuir com esse debate mais geral, procurando demonstrar que a pluriatividade não é um fenômeno marginal ou transitório, confinado a determinadas situações particulares, como também não representa um processo com tendência à generalização das atividades nãoagrícolas para todos os grotões rurais do País. O que se pretende demonstrar é que a pluriatividade é uma característica típica dos processos de desenvolvimento em que a integração dos agricultores familiares à divisão social do trabalho passa a ocorrer não mais exclusivamente através de sua inserção nos circuitos mercantis via processos de produção agropecuários ou mesmo pelas relações de trabalho (assalariamento) em atividades exclusivamente agrícolas. A pluriatividade tende a se desenvolver como uma característica ou uma estratégia de reprodução das famílias de agricultores que residem em áreas rurais situadas em contextos nos quais a sua articulação com o mercado se dá através de atividades não-agrícolas ou para-agrícolas. Objetivamente, a pluriatividade refere-se a um fenômeno que pressupõe a combinação de duas ou mais atividades, sendo uma delas a agricultura. Essa interação entre atividades agrícolas e não-agrícolas tende a ser mais intensa à medida que mais complexas e diversificadas forem as relações entre os agricultores e o ambiente social e econômico em que estiverem situados. Isto faz com a pluriatividade seja um fenômeno heterogêneo e diversificado que está ligado, de um lado, às estratégias sociais e produtivas que forem adotadas pela família e por seus membros e, de outro, dependerá das características do contexto em que estiverem inseridas.

Nos anos recentes, difundiu-se entre os cientistas sociais brasileiros a percepção da necessidade de repensar os temas agrários e o mundo rural, esforço este simbolizado pelo uso cada vez mais recorrente do termo ruralidade. Diversas razões informariam essa nova agenda de análise sociológica. Por um lado, o intenso processo migratório, que apenas nos últimos quarenta anos deslocou mais de 40 milhões de pessoas do campo para cidade, reduzindo a participação da população rural de 54,6\%, em 1960, para 24,5\%, em 1991, e para apenas 18,8\%, em 2000. Por outro lado, argumenta-se igualmente que as próprias alterações produtivas da agricultura, decorrentes de 
sua inserção plena na economia capitalista através da consolidação dos chamados complexos agroindustriais, teriam transformado os agricultores, em muitas regiões agrárias, em um grupo profissional como outro qualquer. Muitos pesquisadores perceberam nessas mudanças o fim da dicotomia rural-urbano e a unificação das relações campo-cidade como inequívoco sinal de esvanecimento do objeto de estudo da chamada "sociologia rural", em virtude da rápida mudança das suas peculiaridades ou mesmo devido à perda de autonomia da agricultura, enquanto um setor produtivo específico. Portanto, o próprio desenvolvimento do capitalismo na agricultura estaria operando também um processo de homogeneização social e econômica dos espaços agrários, sendo citados como exemplos dessa superação a influência crescente dos meios de comunicação de massa e os novos padrões de consumo, que chegam aos rincões mais remotos do interior brasileiro. Em oposição a essa leitura, muitas vezes linear e esquemática, chegou-se a propor a instauração de uma sociologia dos processos sociais agrários, cuja proposta inicial, no entanto, também não teve maiores conseqüências práticas, até porque, nos anos recentes, muitos sociólogos brasileiros abandonaram essa perspectiva.

Assim, malgrado vários esforços, as novas possibilidades teóricas e metodológicas de interpretação sociológica do "rural brasileiro" não parecem ter sido inteiramente bem-sucedidas e suas proposições não se materializaram em rearranjos institucionais e reorientações para retomar o antigo vigor dos estudos rurais-agrários no Brasil, sendo notória a diminuição do número de centros de pesquisa que se dedicam a esses temas. Além disso, no terreno das abordagens teóricas, também não se descortinaram as ferramentas analíticas que, assim se esperava, surgissem ao longo da década de 1990. Em parte, talvez essa situação possa estar relacionada às mudanças estruturais que vêm ocorrendo no sistema nacional de ensino e pesquisa de pós-graduação, mas é provável que estes condicionantes institucionais não sejam suficientes para explicar a relativa paralisia de posicionamento das Ciências Sociais, no período recente, em relação às transformações que afetam as populações que vivem fora dos centros urbanos de alta densidade demográfica.

Todavia, evidenciar uma determinada situação, que, em larga medida, decorre de uma percepção relativamente subjetiva do estado da arte nesse campo do conhecimento, não implica um diagnóstico rigorosamente preciso e, tampouco, a indicação de alternativas fáceis ou proposições seguras de mudança. Na verdade, verifica-se que, na atualidade, o desafio intelectual exige reflexões não apenas sobre objetos de pesquisa e investigação dos cientistas, mas também sobre o próprio itinerário metodológico e o projeto teórico das 
Ciências Sociais, que têm como alvo as sociedades rurais e suas transformações.

O esforço de pesquisa, materializado neste livro, não se arroga, por certo, à tarefa de indicar caminhos ou atalhos fáceis para essas reflexões mais gerais, mas pretende contribuir no sentido de reafirmar a necessidade de manutenção de um espaço próprio a uma tradição do pensamento social, brasileiro que se ocupa do estudo das relações sociais e produtivas do meio rural e da agricultura e das transformações políticas, culturais e simbólicas daí decorrentes. Nesse sentido, talvez seja coerente admitir uma certa dificuldade na definição do que seja a ruralidade atual e do modo de proceder para recortar ou construir os objetos próprios aos estudos rurais e agrários. Essa atitude, por certo, não implica um retorno às soluções apresentadas pela Sociologia Rural de extração funcionalista ou mesmo sua substituição por uma eventual "Sociologia do Rural" ou outra expressão qualquer que venha a ser utilizada apenas para demarcar terreno.

Como saída a esses impasses, parece ser válida a sugestão de Marcel Jollivet (1997), que aliás corrobora uma antiga, porém atual, sugestão de José de Souza Martins (1986), quando ressalta que o sociólogo que estuda "o rural" precisa compreender que o seu objeto não é delimitado pelo adjetivo de lugar, nem delimitado por um determinado espaço físico ou uma atividade produtiva (o espaço rural como lugar da produção agrícola), mas pelo próprio referencial epistemológico da Sociologia, como ciência que estuda as relações e interações sociais e suas transformações. Esse entendimento implica admitir que o rural constitui-se em um espaço onde transcorre uma teia de relações sociais, políticas, econômicas e culturais que precisa ser escrutinado por análises multidisciplinares que consigam responder à diversidade de formas e modos pelos quais se operam as transformações e as mudanças. Essa postura demanda a ampliação do diálogo da Sociologia com as outras tradições do pensamento social que estudam as sociedades rurais, como a Geografia e a Economia entre outras, o que pode auxiliá-la a romper com seu arraigado corporativismo disciplinar.

A partir desse esforço, talvez seja possível demonstrar que o mero fato do Brasil observar a rápida redução de sua população majoritariamente rural e ocupada em atividades agrícolas não implica que a Sociologia tenha perdido seu valor interpretativo. Mais do que isso, que, frente a esses processos, a Sociologia que se ocupa dos temas e objetos rurais e agrários teria perdido seu sentido. O fracasso analítico da Sociologia Rural somente poderia ser decretado se, como ciência social, tivesse sido incapaz de revelar e explicar as causas desse processo, sua natureza, seus mecanismos de evolução e suas características mais salientes. Como isso parece não ter ocorrido, sua pertinência e atualidade não podem ser desconsideradas. 
Embora os objetivos deste livro sejam confinados a uma delimitação bem mais restrita e definida, que não avança pela seara da problematização epistemológica,é inegável que pretende aportar alguma contribuição, por modesta que seja, aos estudos sociológicos brasileiros que enfocam as sociedades agrárias e as populações rurais. Para tal, pretende-se construir essa contribuição à luz do debate atual e das reflexões centradas na diversidade e na complexidade da agricultura familiar nas sociedades contemporâneas.

Nesses termos, a reflexão se propõe a examinar as relações da agricultura familiar com a emergência e a consolidação das atividades nãoagrícolas no espaço rural e a formação de unidades produtivas crescentemente identificadas com a pluriatividade das famílias rurais. Este trabalho agrega-se, portanto, às pesquisas que vêm sendo realizadas para aprofundar os conhecimentos sobre a agricultura familiar e suas possibilidades de desenvolvimento social e econômico no espaço rural. Nos anos recentes, vários cientistas sociais vêm dedicando seus estudos e análises às formas familiares (Newby, 1987, 1980). Esse trabalho intelectual tem sido desenvolvido sob variados focos, podendo-se extrair pelos menos dois ensinamentos. O primeiro indica a existência de diferentes estratégias sociais e econômicas através das quais as populações, grupos e indivíduos identificados com a agricultura familiar vêm viabilizando sua reprodução social e sobrevivência econômica nas sociedades contemporâneas (Fuller, 1990; Marsden, 1992). O segundo e maior aprendizado demonstra que, pelo menos nas nações mais desenvolvidas, o Estado tem sido o maior responsável pela manutenção de políticas públicas e formas de apoio à expansão e à consolidação das unidades que se organizam e estruturam com base no trabalho familiar (Abramovay, 1992).

Este livro situa-se no primeiro veio citado, alinhando-se às pesquisas cujo objetivo tem sido o de demonstrar os mecanismos e as estratégias que viabilizam, e em certos casos até ampliam e fortalecem, as formas familiares no campo. Como terreno empírico para o estudo dessas unidades familiares escolheu-se as regiões da Colônia Velha alemã, no Rio Grande do Sul (hoje composta pelas microrregiões do Vale do Sinos, Encosta da Serra, Vale do Caí e Vale do Taquari) e a região do Médio Vale do Itajaí, em Santa Catarina. Nestas regiões, parte significativa das unidades familiares não depende mais exclusivamente do trabalho agrícola para garantir o atendimento às suas necessidades e viabilizar sua reprodução social, pois ampliam o orçamento doméstico através do recurso às atividades realizadas fora da propriedade. Na maioria das vezes, são unidades que diversificaram suas fontes de renda e, além da agricultura, os membros da família exercem várias outras atividades, algumas inclusive em tempo parcial. Se anos atrás, os colonos recorriam esporadicamente aos trabalhos não-agrícolas, visando complementar as receitas da 
propriedade, atualmente este fenômeno é permanente e representa muito mais do que uma mera suplementação de rendas.

Essa combinação permanente de atividades agrícolas e não-agrícolas, em uma mesma família, é que caracteriza e define o fenômeno denominado de pluriatividade, que tanto pode ser um recurso do qual a família faz uso para garantir a reprodução social do grupo ou do coletivo que lhe corresponde, como também pode representar uma estratégia individual dos membros que constituem a unidade doméstica. A pluriatividade também pode adquirir significados diversos e servir para satisfazer projetos coletivos ou como resposta às decisões individuais. Além disso, as características da pluriatividade variam de acordo com o indivíduo-membro que a exerce, pois tal processo social acarreta efeitos distintos sobre o grupo doméstico e sobre a unidade produtiva, de acordo com variáveis como o sexo ou a posição na hierarquia familiar de quem a pratica. $\mathrm{O}$ mesmo pode-se dizer das condições sociais e econômicas locais, do ambiente ou do contexto, em que ocorre a pluriatividade. Nesse caso, variáveis exógenas à unidade familiar, como o mercado de trabalho e a infra-estrutura disponível, entre outros, são fatores determinantes da evolução e tendências de tais fenômenos.

Essa delimitação da problemática social investigada, bem como as hipóteses que orientaram o itinerário da pesquisa realizada originalmente para a tese de doutoramento, defendida na UFRGS em 1999, fornecem o escopo da discussão teórica sobre o significado da pluriatividade. Na perspectiva aqui perseguida, a pluriatividade deve ser entendida como uma estratégia de reprodução social de unidades que se utilizam fundamentalmente do trabalho da família, em contextos nos quais sua integração à divisão social do trabalho não decorre exclusivamente dos resultados da produção agrícola, mas, sobretudo, através do recurso às atividades não-agrícolas e mediante a articulação com o mercado de trabalho. Nesse sentido, assim argumenta-se, embora integradas ao ordenamento social e econômico hegemônico, as formas familiares encontram espaços e mecanismos não apenas para subsistir, mas muitas vezes para se afirmar como uma forma social de características variadas e diversas em um regime capitalista.

A partir dessa compreensão, buscou-se verificar por que, no Brasil, os estudos sobre a agricultura familiar são ainda recentes, pois se iniciaram somente a partir de meados da década de 1990. É bem verdade que, muito antes desse período, haviam sido realizados estudos sobre diversas categorias sociais que operam segundo a natureza das formas familiares de produção e organização social. Contudo, uma leitura desses trabalhos indica que raramente os autores se referem a estas categorias como de agricultores familiares, expressão que passou a se generalizar nos últimos quinze anos no País. A chegada tardia das discussões e pesquisas sobre a agricultura familiar no Brasil pode ser entendida com base na identificação dos referenciais teóricos que inspira- 
ram boa parte dos estudiosos, fortemente influenciados por aportes analíticos que mantiveram um excessivo apego às formulações clássicas em torno do problema agrário nacional e dos processos de formação e luta de classes sociais no campo.

Fora do ambiente acadêmico brasileiro, ao contrário, produziu-se, nos últimos vinte anos, uma vasta bibliografia a partir de diferentes correntes do pensamento social, que superaram esses limites e propuseram um profícuo debate sobre as razões e o sentido da persistência das formas familiares, estabelecendo, sobretudo, reflexões acerca das condições e dos obstáculos ao processo de desenvolvimento do capitalismo no campo. Essas discussões não permitiram apenas avançar na compreensão da inserção da agricultura familiar nas transformações capitalistas da segunda metade do século XX, mas também produziram uma crítica teórica e epistemológica à Sociologia $\mathrm{Ru}$ ral de inspiração funcionalista, da qual resultou a emergência da chamada Sociologia da Agricultura, a partir de meados da década de 1980.

No primeiro capítulo deste livro, empreendeu-se um esforço de síntese dessa trajetória, que pode ser entendida como uma tentativa de introduzir (embora alguns autores tratados e citados já sejam conhecidos no País) esse debate internacional no cenário brasileiro, ainda insuficientemente conhecido do público brasileiro. Embora seja uma revisão orientada pela contribuição de diferentes autores, o foco da análise concentrou-se nas formulações sobre o tema específico da agricultura familiar e, quando possível, sobre o papel e o significado da pluriatividade. A partir dessa leitura, são apontadas algumas críticas e limites à utilização desse arcabouço conceitual ao estudo da agricultura familiar em situações em que predomina a pluriatividade e o recurso às atividades não-agrícolas é de fundamental importância à reprodução social das unidades familiares.

Do ponto de vista teórico, este trabalho sustenta-se no pressuposto de que, para explicar e tentar compreender sociologicamente como operam as formas familiares nas sociedades modernas, deve-se entender os mecanismos e as estratégias pelas quais os indivíduos e as famílias que se organizam social e economicamente sob a égide da organização produtiva e social de caráter familiar viabilizam sua inserção na divisão social do trabalho. Nesse sentido, acredita-se que este esforço é significativamente distinto daqueles estudos que buscaram entender as formas familiares exclusivamente pelo papel ou função que exerciam no processo de acumulação de capital. Assim posta, a perspectiva analítica proposta revela sua afinidade com um certo enfoque proposto a partir da teoria social marxista. Nesse sentido, o esforço recai sobre a possibilidade de utilização da dialética como ferramenta teórica e metodológica que permite entender os processos de articulação, integração e exclusão das formas sociais que não assumiram as características 
arquetípicas das relações capitalistas clássicas e que não apenas continuam a existir, mas parecem até mesmo estar em profusão em certos contextos, tal como é o caso das formas familiares na agricultura. Assim, a abordagem teórica que informa o estudo da agricultura familiar e da pluriatividade orienta-se pela análise dos processos sociais e econômicos que têm levado à articulação ou superação das formas familiares de organização do trabalho e da produção nas sociedades contemporâneas. Essas formas familiares incluem os agricultores do Rio Grande do Sul e de Santa Catarina que, no período recente, vêm vislumbrando novas estratégias de garantia de sua reprodução social e econômica sem que se tenha alterado sua característica fundamental, qual seja, seu funcionamento com base no trabalho da família. A questão que se apresenta, portanto, do ponto de vista da contribuição teórica deste estudo ao conhecimento sociológico, refere-se à elucidação dos mecanismos e das estratégias que explicam como essas unidades se relacionam com a sociedade e de que modo tais relações afetam e alteram a sua própria existência.

Como se percebe, embora seja um trabalho empiricamente delimitado sobre a pluriatividade das unidades familiares, pretende-se participar do debate sobre as questões que desafiam o pensamento sociológico contemporâneo, mormente as discussões em torno do modo como os indivíduos se relacionam com estruturas e processos societários, tão bem reportados no chamado debate micro versus macro referenciais sociológicos. $\mathrm{Na}$ verdade, pretende-se contribuir com a discussão travada pela sociologia crítica, na tentativa de explicar as mudanças que afetam as sociedades contemporâneas. Essa tentativa é ensaiada no segundo capítulo do livro, no qual são apresentadas as possibilidades analíticas oferecidas por autores da chamada Sociologia da Agricultura, como Terry Marsden, e o resgate de aspectos do modelo analítico proposto por Alexander Chayanov para estudar as unidades que se organizam com base no trabalho familiar.

Acredita-se que o próprio tema da pluriatividade e da agricultura familiar, conforme ressaltado por Fuller (1990) requer, por si só, alguns deslocamentos analíticos e a introdução de conceitos e unidades de análise multidisciplinares. Por essa razão, propõe-se utilizar a família rural como unidade de análise, separando-a, para fins heurísticos, em unidade de produção e grupo doméstico. Essa flexibilização da unidade de análise fornece uma solução analítica útil que permite explicar, comparativamente, o comportamento e as estratégias das famílias rurais e dos indivíduos-membros que as integram. Essa manobra heurística ou reconstrução sintética foi construída para que os conceitos analíticos e as perspectivas teóricas possam interagir sobre as instâncias empíricas observadas (o modo de ser e agir das famílias e dos indivíduos), desembocando naquilo que Florestan Fernandes (1980, p. 39) definiu como a fase final do processo de re- 
construção da realidade nas Ciências Sociais: produzir “em primeiro lugar, uma representação analítica, uma reconstituição empírica pura dos caracteres e propriedades da realidade social [e], em segundo lugar, encará-la como representação sintética, como explanação descritiva e interpretativa da realidade social, mediante categorias universais do pensamento científico".

A partir dessas orientações, a agricultura familiar e a pluriatividade serão analisadas, comparativamente, com base em dois estudos de caso, um deles focalizando a localidade de Padre Eterno Ilges (município de Santa Maria do Herval), no Rio Grande do Sul, e o outro a localidade de Braço do Sul, situada no distrito de Vila Itoupava (município de Blumenau), em Santa Catarina. O método é utilizado de duas maneiras: comparando-se os dois casos estudados diretamente, um em cada Estado, e comparando-se as famílias de agricultores com as famílias pluriativas, o que permitiu comparar não apenas as famílias entre os dois Estados, mas também em uma mesma localidade, entre famílias de agricultores e famílias pluriativas.

A organização final do livro divide-se em três eixos de análise e discussão da agricultura familiar e da pluriatividade. O primeiro deles, que é explicitado nos dois primeiros capítulos, ocupa-se do debate teórico e metodológico, cujo objetivo não é apenas uma revisão do estado da arte desses temas, mas também a apresentação de uma proposta de enfoque para a investigação empírica. O segundo eixo, desenvolvido no terceiro capítulo, tem como objetivo fundamental apresentar a relevância que vêm adquirindo as atividades não-agrícolas no espaço rural, nos países capitalistas mais avançados ou na América Latina e no Brasil, especificamente. Nesse capítulo, empreendeu-se uma pesquisa detalhada em fontes secundárias, especialmente a partir da consulta a dados estatísticos sobre o emprego rural (agrícola e não-agrícola) e sobre a pluriatividade, discutindose as transformações recentes da agricultura e da estrutura da ocupação da força de trabalho rural. No terceiro eixo, que abrange os capítulos 4 e 5 , estão expostos os estudos de caso realizados no Rio Grande do Sul e em Santa Catarina. Os resultados da pesquisa de campo são apresentados sob o foco de variáveis-chave, tais como a composição demográfica das famílias, a forma de uso da propriedade, os processos produtivos adotados, as rendas, entre outros ângulos possíveis, e são interpretadas a partir da utilização do método comparativo.

Além desses eixos gerais que permitem uma amarração interna ao trabalho, cada capítulo possui uma rationale particular, que pode ser expressa nos seguintes termos. No capítulo primeiro são discutidas algumas das principais abordagens da teoria social sobre a agricultura familiar e seu papel ou função no desenvolvimento do capitalismo. A indagação fundamental que se pretende responder nessa parte está relacionada à análise dos referenciais 
analíticos que levaram autores como Mann, Goodman, Servolin, Friedmann, Lamarche, Gasson e outros, a oferecer respostas tão diversas acerca do significado, da racionalidade e do lugar social da agricultura familiar nas sociedades modernas.

No segundo capítulo, discutem-se as relações entre a pluriatividade e a agricultura familiar sob o ponto de vista teórico e conceitual. Inicialmente retoma-se o debate sobre o estatuto heurístico da pluriatividade e da agricultura em tempo-parcial. Apresentam-se os limites à utilização da noção de pluriatividade como um conceito, pois trata-se de noção que se refere mais a um conjunto de fenômenos ou formas de combinação de atividades agrícolas e não-agrícolas, que podem variar segundo o contexto e a situação histórica. Para operacionalizar esse deslocamento teórico e torná-lo útil à interpretação das situações concretas investigadas, sugere-se a eleição da família como a unidade de análise e a utilização do conceito de estratégia para analisar a pluriatividade e a agricultura familiar.

No terceiro capítulo, são apresentadas as transformações recentes da estrutura agrária contemporânea, dedicando-se atenção especial ao processo denominado de reestruturação capitalista e seus impactos sobre o espaço rural e agrário. Informa-se que uma das consequiências da reestruturação é a emergência das atividades não-agrícolas na estrutura agrária das nações capitalistas desenvolvidas bem como da América Latina. Nesse capítulo, também são apresentados os dados sobre a dinâmica do mercado de trabalho rural e as ocupações em atividades agrícolas e não-agrícolas no Brasil e na região Sul. Esses dados resultam da participação do autor no Projeto Rurbano, iniciado em 1996 e coordenado pelo professor José Graziano da Silva, da Unicamp. Este projeto de pesquisa vem apresentando profícuos resultados sobre a dinâmica do mercado de trabalho rural brasileiro através da utilização das informações da Pesquisa Nacional de Amostragem por Domicílios (PNAD), realizada pelo IBGE.

A partir dos dados produzidos pelo Projeto Rurbano, no quarto capítulo do livro são analisadas as informações sobre a ocupação e a dinâmica das atividades agrícolas e não-agrícolas da população economicamente ativa do Rio Grande do Sul e de Santa Catarina. Além dos dados secundários, também é apresentada uma análise das principais transformações da agricultura familiar nas microrregiões da Colônia Velha alemã, no Rio Grande do Sul, e do Vale do Itajaí, em Santa Catarina, onde se realizou uma pesquisa de campo. Nas seções finais desse capítulo também são indicados os passos metodológicos, os procedimentos e as definições operacionais seguidos para o levantamento dos dados empíricos sobre a pluriatividade nos dois estudos de caso, localizados nas comunidades de Padre Eterno Ilges, no Rio Grande do Sul, e Braço do Sul, em Santa Catarina. 
No capítulo final, são apresentados os resultados da pesquisa de campo sobre as famílias de agricultores e famílias pluriativas no Rio Grande do Sul e em Santa Catarina. Optou-se por uma forma de exposição dos resultados consoante os marcos teóricos e analíticos sugeridos nos capítulos anteriores, especialmente o segundo. Assim, foram selecionadas variáveischave, expressas na divisão por itens, tais como a caracterização das famílias (ou o grupo doméstico), a caracterização da unidade produtiva (a propriedade, a forma de uso da terra e o processo produtivo), a forma de ocupação e alocação da força de trabalho e os rendimentos auferidos pelas unidades familiares de agricultores e pluriativas. Além disso, também se discute o modo de reação dos indivíduos que efetivamente exercem a combinação de atividades agrícolas e não-agrícolas frente à sua condição de pluriativos. Esse capítulo constitui-se em uma tentativa de demonstração empírica de como a pluriatividade opera no interior das famílias rurais e como as características demográficas dos indivíduos que formam essas unidades, bem como o contexto em que estão inseridos, influenciam nessa estratégia de reprodução familiar.

Ao leitor não escapará, por certo, que este livro representa a continuidade de um trabalho de investigação que se iniciou no final da década de 1980, quando se estudou a articulação promovida pelo processo de "industrialização difusa" do setor coureiro-calçadista gaúcho com a agricultura familiar (Schneider, 1994, 1999). Originalmente, este livro foi apresentado como uma Tese de Doutorado, defendida no final de 1999, junto ao Programa de Pós-Graduação em Sociologia da UFRGS. No ano de 2000, a tese foi agraciada com o Prêmio José Gomes da Silva de Melhor Tese de Doutorado em Sociologia Rural, conferido pela Sociedade Brasileira de Economia e Sociologia Rural (SOBER) e, no ano de 2001, obteve o $2^{\circ} 1 \mathrm{lu}-$ gar no Prêmio Mérito Agrário, conferido pelo Núcleo de Estudos Agrários e Desenvolvimento Rural (NEAD), órgão ligado ao Ministério do Desenvolvimento Agrário do Governo Federal. Este livro constitui-se em versão modificada e reescrita da tese original. Tendo em vista o decurso do tempo, algumas partes foram inteiramente suprimidas e outras acrescentadas, procurando adequar o livro ao pensamento atual de seu autor sem, no entanto, descaracterizar o trabalho original. 


\section{CAPÍTULO 1 \\ Teoria social, capitalismo e agricultura familiar}

No período recente, a expressão "agricultura familiar" vem ganhando legitimidade social e científica no Brasil, passando a ser utilizada com crescente frequiência nos discursos dos movimentos sociais rurais, pelos órgãos governamentais e por segmentos do pensamento acadêmico, especialmente pelos estudiosos das Ciências Sociais que se ocupam da agricultura e do mundo rural.

Ao contrário do que imaginavam muitos cientistas sociais brasileiros, a década de 1990 foi pródiga em recolocar em cena temas e questões que pareciam ter sido sepultados pelo curso dos acontecimentos históricos recentes. Assim tem sido com o debate e as ações sociais em relação à reforma agrária, talvez o mais emblemático desses temas, que havia conquistado grande projeção nos ambientes acadêmicos, intelectuais e políticos a partir do final da década de 1950, silenciado durante o ciclo militar e tendo retornado posteriormente à pauta dos debates. Após o golpe militar de 1964, somente se voltou a falar em reforma agrária a partir de meados da década de 1980 com o início da abertura democrática, ainda que, nesse período, as discussões e expectativas tenham sido rapidamente mitigadas pela aprovação de dispositivos anti-reformistas durante a Constituinte de 1988. Mas, nos anos noventa, a luta pela terra e o Movimento dos Trabalhadores Rurais Sem-Terra (MST) voltaram a ocupar expressivos espaços no cenário político nacional, cujos contornos não cabe aqui aprofundar, pois além de serem relativamente conhecidos encontram-se fora dos domínios deste trabalho. Algo semelhante vem ocorrendo com os estudos sobre as relações de trabalho e os sistemas produtivos na agricultura, ou melhor, com as análises acerca de qual modelo de uso da terra e forma de propriedade pode garantir ao País a resolução de seus problemas com o abastecimento alimentar e os processos redistributivos.

Para diversos autores que imaginavam que a chamada "questão agrária" brasileira estava resolvida e que também não fazia mais qualquer sentido uma aposta intelectual para estudar os grupos sociais que vivem fora dos espaços urbanos e industrializados, esses dois exemplos, além de tantos outros, parecem indicar que o estudo das sociedades agrárias, do espa- 
ço rural e da economia agrícola ainda requer um olhar e uma contribuição das Ciências Sociais.

Todavia, o resgate analítico do sentido acadêmico, político e social da questão agrária e do estudo das sociedades e grupos que hoje vivem fora das cidades não se assenta mais sobre as mesmas bases do passado, quando abordar esse tema implicava usualmente discutir a produção agropecuária, os sistemas produtivos, o comércio e as trocas agrícolas, os padrões tecnológicos, a estrutura fundiária, a inversão de capital, entre outros focos então privilegiados, e buscar saber quais eram os mecanismos que levariam (ou não) os agricultores e os habitantes do mundo rural a se inserir na economia de mercado, ou até mesmo a desenvolver processos sociais que negavam a ordem capitalista. O debate sobre as famílias rurais e seu papel ou lugar na estrutura agrária constituiu-se, durante um longo período, no objeto central dos estudos sobre o mundo rural.

$\mathrm{Na}$ verdade, aquele foi um debate fortemente marcado por um viés econômico e urbano, no qual estudar as formas sociais de trabalho e produção no campo fazia sentido à medida que produzisse explicações e interpretações sobre os rumos do desenvolvimento do capitalismo em geral e o papel da agricultura nesse processo. Assim posta, a discussão da questão agrária (ou do agrarismo) era eminentemente uma "questão política", que atraía seguidores de toda ordem, tanto à esquerda como à direita. Para estudiosos à esquerda, estava em questão a luta de classes e o papel dos grupos sociais rurais, ao passo que para aqueles situados à direita, tratavase de um problema de adequação de políticas econômicas para alavancar o desenvolvimento rural e, assim, fazer com que a agricultura cumprisse seu papel no processo de acumulação capitalista.

Contudo, embora a questão agrária brasileira ainda não tenha sido superada, é preciso ter claro que, nos dias atuais, a dicotomia campo-cidade não se resume à diferença de classes e tampouco a meros problemas de política econômica. Atualmente, não se fala apenas da agricultura e da produção agrícola, mas do rural lato sensu. Como destacou Jollivet (1997, p.24), "passamos de uma terminologia que acentuava o conteúdo (o mundo rural) para uma outra que acentua o contido (o espaço rural), o adjetivo é transformado em substantivo, mas para denominar, sempre, o espaço e o ambiente social no qual ele vive". Por certo, a agricultura como atividade produtiva não perdeu sua importância e não deixou de ser parte integrante do mundo rural. O que está acontecendo, no entanto, é que o rural não mais se resume à atividade econômica agrícola, pois a ele passaram a incorporar-se, nas leituras analíticas e nas representações sociais, outras dimensões como a natureza, as famílias rurais, as paisagens, o patrimônio cultural e as tradições, entre outras. 
Embora a agricultura guarde um lugar de destaque no espaço rural,é errôneo imaginar que ela própria não tenha sido modificada ao longo dessa trajetória. Em vários países, conforme se verá, a dinâmica da própria agricultura no espaço rural é condicionada e determinada pelas outras atividades ali praticadas e é percebida como $u m$ dos agentes das relações que se estabelecem entre a sociedade e o espaço. Talvez o exemplo emblemático, entre outros, dessa mudança na "forma de ser" do rural seja a emergência e a expansão das "unidades familiares pluriativas", pois é cada vez mais frequiente que uma parte dos membros das famílias residentes no meio rural se dedique às atividades não-agrícolas, dentro ou fora das propriedades. A pluriatividade refere-se à emergência de situações sociais em que os indivíduos que compõem uma família com domicílio rural passam a dedicar-se ao exercício de um conjunto variado de atividades econômicas e produtivas, não necessariamente ligadas à agricultura e ao cultivo da terra, e cada vez menos executadas dentro da unidade de produção.

Neste capítulo pretende-se introduzir o debate acadêmico realizado no período recente no Brasil, inspirado na tradição marxista. Como se verá, trata-se de produção teórica que representa um ingente esforço de reflexão sobre as razões que permitem a sobrevivência e a reprodução da agricultura familiar sob o capitalismo. Essa revisão inicia-se com a retomada do debate brasileiro, cujo objetivo é tentar desvendar os motivos que justificam a ausência dessa temática entre as discussões das Ciências Sociais brasileiras, até, pelo menos, a década de 1990. A seguir, são expostos os argumentos e as bases teóricas sobre as quais se assentam alguns dos principais trabalhos sobre a agricultura familiar publicados recentemente no Brasil. Na seqüência, apresenta-se a proposta teórica da corrente que Buttel, Larson e Gillespie Jr. (1990) passaram a chamar de Sociologia da Agricultura e as diferentes vertentes, ainda no campo da tradição marxista, que buscaram explicar a persistência da forma familiar no regime capitalista. A primeira oferece argumentos baseados na idéia dos obstáculos estruturais, impostos pela própria natureza, para que a agricultura se tornasse uma atividade "interessante" ao capital. A segunda, no entanto, indica que a manutenção da agricultura familiar deve-se a razões endógenas, próprias das unidades baseadas na utilização de trabalho não-assalariado. Além dessas duas, também se apresentam, en passant, os esforços recentes de alguns autores na elaboração de modelos de análise da agricultura familiar. Na seção final, discutem-se os principais avanços realizados no interior da tradição marxista, mas também seus limites e lacunas, o que permite, no último item, retomar o conjunto de argumentos apresentados. 


\subsection{TEORIAS DAAGRICULTURAFAMILIAR}

Uma revisão das principais contribuições teóricas do pensamento social que têm sido influentes no período recente para a abordagem dos temas relacionados às sociedades rurais e à agricultura certamente apontaria o marxismo como uma das vertentes analíticas que mais se dedicou a esses objetos. ${ }^{1}$ O predomínio do instrumental analítico marxista é ainda mais significativo em relação às análises mais específicas sobre a agricultura familiar e as formas sociais de trabalho vigentes no mundo rural. Entre as hipóteses que justificam essa hegemonia pode-se apontar, provavelmente, o próprio referencial epistemológico com o qual opera a teoria social crítica, situado no campo dos aportes holísticos e nomológicos, que privilegiam o estudo das relações sociais e econômicas, a ação social e/ou os comportamentos e as representações dos indivíduos. Já com relação a outros temas, como é o caso dos processos de difusão e adoção do progresso tecnológico pelos agricultores, a contribuição da Sociologia Rural de orientação funcionalista (especialmente a norte-americana) certamente registra maior acúmulo de trabalhos. No entanto, as opções teóricas e metodológicas não devem ser feitas de acordo com a variação dos temas a serem estudados, mas, ao contrário, orientadas pelas convicções epistemológicas e científicas do investigador.

Não constitui propósito deste livro elaborar um quadro exaustivo de revisão da bibliografia e do estado da arte que cada uma das principais escolas do pensamento social elaborou sobre as sociedades agrárias e o mundo rural. O tema aqui proposto e o enfoque escolhido integram uma trajetória de pesquisa iniciada há vários anos, cuja preocupação central tem sido a reflexão sobre as formas sociais de organização do trabalho, da produção e da sociabilidade de grupos sociais rurais. Do ponto de vista teórico, o trabalho não representa apenas uma tentativa de explicar determinado objeto sociológico a partir de uma perspectiva crítica, mas, igualmente, o amadurecimento de determinada perspectiva epistemológica que se sedimenta em torno da herança do método histórico e dialético. Trata-se, também, de uma tentativa de testar a capacidade explicativa de um método informado pelo referencial holístico e nomológico (o marxismo) de situações, fenômenos e comportamentos microssociológicos, como é o caso dos indivíduos pluriativos e das famílias rurais investigadas.

\footnotetext{
${ }^{1}$ Entre outras abordagens, podem ser citadas a teoria do continuum rural-urbano, forjada no seio dos estudos de comunidade de Redfield e outros, das teorias da modernização, da contribuição inequívoca da Rural Sociology norte-americana, com suas abordagens behavioristas e empiricistas, além, é claro, da contribuição da Sociologia Rural funcionalista francesa de Henry Mendras (Schneider, 1997).
} 
Antes de adentrar nas questões de natureza substantiva ligadas a esse debate, cabe enfatizar que a sua retomada está relacionada, ao mesmo tempo, aos referenciais teóricos que guiam este estudo e ao próprio objeto aqui apurado. Ao interpretar a pluriatividade como uma das características da agricultura familiar contemporânea, faz-se mister apresentar os argumentos que sustentam essa proposição e guiam essa perspectiva analítica. O que se apresenta a seguir tem, portanto, um duplo objetivo: primeiro, mostrar como a insuficiência (e apontar quais as razões) do debate brasileiro sobre a agricultura familiar impôs estreitos limites para que se estabelecesse uma relação entre compreensões analíticas sobre o debate da agricultura familiar e o emergente tema da pluriatividade e, em segundo lugar, buscar evidenciar esses mesmos limites a partir da bibliografia específica sobre a agricultura familiar, no caso, a produção dos "neomarxistas", enfoque que, em determinado momento, passou a perceber a pluriatividade ou a opção pelas atividades nãoagrícolas como uma das possibilidades de afirmar essa forma social na estrutura agrária do capitalismo contemporâneo.

Seguindo-se aos escritos fundadores de Marx, com a exceção notável das contribuições de Lênin e Kautsky (este último escassamente difundido no Ocidente até meados da década de 1960), o debate marxista sobre a agricultura e as relações sociais por ela engendradas permaneceram circunscritos ao seu papel econômico no interior do processo de desenvolvimento do capitalismo. Ou seja, a principal questão perseguida pela maioria dos autores consistia em investigar se a instauração do modo de produção capitalista acarretava ou não determinadas formas de propriedade (que, assim acreditava-se, seriam necessariamente semelhantes àquelas estudadas por Marx em relação ao caso inglês) e, em consequiência, um certo tipo de estrutura de classes. Por esta razão, entre a década de 1920 e meados dos anos sessenta, a maior parte dos estudos propriamente sociológicos sobre as sociedades agrárias e o mundo rural foi realizada por outras tradições teóricas do pensamento social que não o marxismo, como é o caso, em particular, do estrutural-funcionalismo (Newby, 1987).

Nesse sentido, é sintomático o fato de que, para o marxismo, no período mencionado, a agricultura e o mundo rural tivessem sido tratados como "questão agrária", expressão que rotulou o debate acerca dos rumos e especificidades da penetração do capitalismo na agricultura, sob o ponto de vista do processo de acumulação de capital e de formação da estrutura de classes. As relações sociais e as categorias agrárias eram tratadas sob tal enfoque a partir da perspectiva do desenvolvimento do capitalismo. Embora tenha havido alguns impasses críticos em relação a certos aspectos dessa tradição, é preciso reconhecer que a abordagem marxista, ao contrário das outras vertentes sociológicas, teve o mérito de mostrar como determinadas formas sociais são superadas ou elimi- 
nadas, à medida que avança o processo de divisão social do trabalho na sociedade capitalista e indicar como aparecem novas categorias em seu lugar. As ressalvas, como se verá mais adiante, referem-se, sobretudo, a um evidente grau de reducionismo conceitual, fruto de interpretações dedutivistas em relação à contribuição original de Marx, que acabou privilegiando excessivamente os aspectos econômicos das relações sociais do campo, relegando a plano secundário as demais dimensões que conformam os arranjos societários. Apesar disso, nenhuma outra tradição teórica do pensamento social foi capaz de produzir interpretações tão vigorosas e abrangentes sobre o desenvolvimento do capitalismo na agricultura e as transformações das sociedades rurais e agrárias.

Contudo, a partir de meados da década de 1970, a literatura marxista sobre a agricultura e o mundo rural ganhou novo impulso e passou a ser difundida nos principais centros universitários. Essa mudança parece estar fortemente relacionada, naqueles anos, à própria ascensão acadêmica do marxismo enquanto um método científico de análise do social. ${ }^{2}$ Em razão disso, houve um deslocamento da questão agrária original, tal como enfatizado nas obras de Marx, Lênin e Kautsky (aqui entendida como uma questão política de acumulação de forças a favor da luta de classes), para uma reflexão acerca das características e particularidades do processo de desenvolvimento do capitalismo no campo (Buttel,Larson, Gillespie, 1990). Um dos principais temas desse debate foi, e em larga medida ainda continua a ser, a reflexão acerca da estrutura social e das formas da organização produtiva que vigorariam na agricultura capitalista. Nesse sentido, em razão do predomínio da agricultura familiar na estrutura agrária dos países desenvolvidos, que se ampliou fortemente a partir do final da Segunda Guerra Mundial e durante o ciclo expansionário dos "anos dourados" (1945-1973), o debate passou a concentrar-se em torno da persistência das unidades agrícolas baseadas no trabalho dafamília. ${ }^{3}$ Por este motivo, quando se opta pelo estudo da agricultura familiar, deve-se ter consciência de que se trata de um tema umbilicalmente arraigado no pensamento social marxista, embora não seja, evidentemente, de seu domínio exclusivo.

Pela sua complexidade e magnitude, uma revisão abrangente e detalhada da literatura marxista acerca da agricultura familiar certamente não é tarefa simples. Para que esse repto seja menos ardiloso, esta revisão se apoiará em outros trabalhos acadêmicos. Nesse sentido, é preciso reconhecer o extraordinário avanço que trabalhos como os de Hussain e Tribe (1983), em um primeiro momento, e, no caso brasileiro, o referencial estudo de Abramovay (1992) propor-

\footnotetext{
${ }^{2}$ Há quem credite essa chegada do marxismo às universidades e aos centros acadêmicos dos países do capitalismo avançado à contribuição da obra de Louis Althusser e sua extremada ênfase no rigor lógico e conceitual.

${ }^{3}$ Para uma visão histórica da presença da agricultura familiar nos principais países ocidentais, consultar Veiga (1991), Abramovay (1992), Gervais, Jollivet e Tavernier (1977).
} 
cionaram à análise dos principais paradigmas teóricos utilizados pelas Ciências Sociais rurais nas últimas décadas, particularmente quando ressaltaram os limites das formulações clássicas. Abramovay, particularmente, situou corretamente tais limites epistemológicos de cada uma das vertentes teóricas e indicou que os clássicos se interessavam pelos desígnios do que hoje se denomina "agricultura familiar" à medida que esses tinham um papel político a desempenhar como classe no processo de desenvolvimento do capitalismo, argumento que, igualmente, Hussain e Tribe já haviam enfaticamente ressaltado, anos antes. ${ }^{4}$ Isso não quer dizer, evidentemente, que ao se analisar as contribuições mais recentes do pensamento social crítico sobre a forma familiar não se façam referências aos fundadores, que expuseram de modo pioneiro problemas e contradições que, mesmo no presente quadro da História, ainda mantêm surpreendente atualidade.

Entretanto, cabe ainda outra ressalva. Embora se considere que a consulta a outros autores abrevie o desafio de retomar a contribuição do pensamento social marxista sobre a forma familiar de produção na agricultura, isso não quer dizer que se subscrevam todas as conclusões desses autores no que se refere aos limites explicativos do método dialético enquanto teoria social. Esta postura também não implica concordância integral com as análises de algumas vertentes do marxismo sobre as relações sociais na agricultura e no mundo rural. Ao contrário, se pretende resgatar o núcleo metodológico dessa tradição do pensamento sociológico e tentar demonstrar, a partir do estudo da agricultura familiar e da pluriatividade, que essa perspectiva teórica ainda pode ser utilizada como instrumento analítico para fazer avançar o conhecimento sociológico sobre o espaço rural e as relações sociais que nele ocorrem.

Portanto, não cabe aqui um escrutínio dos erros e acertos do marxismo em relação aos desígnios do desenvolvimento do capitalismo no campo e tampouco um esforço comparativo de avaliação em relação às vertentes teóricas concorrentes. O que se pretende demonstrar é que a teoria marxista ainda guarda potencialidades explicativas quando se pretende discutir, como é o caso da presente tese, o trabalho e suas formas de materialização, quer sejam familiares ou sociais, em determinados ambientes econômicos e produtivos, como é o caso das famílias rurais que possuem pequenas propriedades de terra. Sem se fixar exclusivamente nas dimensões econômicas e materiais das unidades familiares, o que se busca é perceber como determinados grupos sociais (famílias de agri-

\footnotetext{
${ }^{4}$ Para Marx eram "produtores parcelários”, para Lênin e Engels eram “camponeses” e Kautsky os designava "pequenos proprietários". Abramovay mostrou em seu estudo que os clássicos jamais chegaram a formular uma "teoria" específica para os agricultores ou camponeses. Os três, indistintamente, acreditavam que a presença dessas categorias poderia ser explicada no escopo de uma teoria geral sobre o próprio desenvolvimento do capitalismo.
} 
cultores e famílias pluriativas) são integrados ou excluídos da divisão social do trabalho. Mais do que isso, pretende-se avaliar de que maneira se produzem essas situações e se são decorrentes de iniciativas individuais e/ou familiares ou decorrentes de condicionantes estruturais, como a pressão do mercado de trabalho, por exemplo.

Nesse sentido, a opção pela análise da pluriatividade a partir do ambiente familiar, focalizando aspectos como a organização do processo produtivo, as formas de uso e alocação da força de trabalho familiar, o investimento e o destino das rendas e as relações de gênero, representa um esforço para demonstrar que, embora a forma familiar seja afetada e de certo modo condicionada pelo mercado e pela dinâmica capitalista de produção, ela tem revelado capacidade de se adaptar e estabelecer estratégias que vêm garantindo sua reprodução social. Trata-se, portanto, de estudar a pluriatividade a partir da perspectiva da agricultura familiar ou, dito de outra forma, buscar compreender e explicar se o recurso crescente à diversificação das atividades econômicas dos indivíduos e das famílias que residem no espaço rural é uma característica estrutural dessas unidades ou, então, se trata-se de uma estratégia de reprodução frente a um determinado contexto ou a um conjunto de oportunidades.

\subsection{ODEBATEBRASILEIRO SOBREAAGRICULTURAFAMILIAR}

No Brasil, permanecem muitas dúvidas e mesmo divergências entre os estudiosos em relação à utilização da noção de agricultura familiar, bem como de pluriatividade. Talvez ainda haja pouca clareza analítica ou consenso em relação ao objeto que se pretende caracterizar ou aos processos sociais e fenômenos empíricos que se quer referenciar quando se utilizam essas noções. Por se tratarem de noções recentes, essa ambivalência conceitual não deve surpreender. No entanto, ao observar-se que essas noções referem-se aos mesmos grupos sociais que a Sociologia e as demais Ciências Sociais brasileiras vêm estudando desde os anos cinqüenta, pode-se perceber seu curso histórico e indagar se tais noções vêm em substituição a outros conceitos e idéias que marcaram a produção científica das últimas décadas, como o campesinato ou a pequena produção.

Neste capítulo, não se pretende fazer uma revisão dos estudos agrários e rurais, realizados nas últimas décadas, com o objetivo específico de responder se a agricultura familiar está se tornando uma noção que vem para substituir conceitos anteriormente utilizados, mas que focalizavam os mesmos grupos sociais. Mesmo sem este objetivo, deve-se reconhecer que, ao se propor um estu- 
do das atividades não-agrícolas e da pluriatividade de indivíduos e famílias que residem no espaço rural e são proprietárias de pequenos lotes de terra-sendo por estas características chamados de "agricultores familiares"-,é mister que se faça uma avaliação da trajetória que levou ao aparecimento dessas denominações e a que grupos sociais se referem.

No Brasil, o debate sobre a agricultura familiar ainda é recente e não possui contornos definidos. Entre os estudos publicados em português que deram impulso decisivo merecem ser citados os trabalhos de Veiga (1991), Abramovay (1992) e de Lamarche (1993, 1999). O maior mérito desses estudos talvez tenha sido o fato de terem revelado que a agricultura familiar é uma forma social reconhecida e legitimada na maioria dos países desenvolvidos, nos quais a estrutura agrária é majoritariamente composta por explorações nas quais o trabalho da família assume uma importância decisiva. Essa "descoberta" foi fundamental não apenas por ter difundido entre os estudiosos brasileiros a noção de agricultura familiar, mas, sobretudo, por ter operado um deslocamento teórico e analítico decisivo na sociologia dos estudos rurais e agrários, cujas preocupações, até então, giravam em torno da discussão do caráter capitalista, tradicional ou moderno, das relações sociais predominantes na agricultura. ${ }^{5}$

O que importa ressaltar, contudo, não é o caráter e as interpretações que esses fenômenos vêm recebendo, mas o próprio reconhecimento da temática da agricultura familiar e dos temas ligados a ela, como é o caso da pluriatividade. Embora incipientes, os estudos específicos sobre a pluriatividade das famílias rurais e do crescimento das atividades não-agrícolas no espaço rural parecem estar descortinando dimensões sociais, econômicas e culturais que ganham proeminência na estrutura agrária brasileira. Ao mesmo tempo, alguns desses trabalhos estão postulando a hipótese de que a pluriatividade e as atividades não-agrícolas que ocorrem no meio rural podem estar contribuindo para que a forma familiar de organização do trabalho e da produção vislumbre novos mecanismos de garantia de sua reprodução material e, até mesmo, a ampliação de sua importância na estrutura social.

Ao se retomar a bibliografia brasileira recente sobre os processos sociais rurais e agrários percebe-se que a incorporação da expressão agricultura familiar ganhou projeção somente a partir do final dos anos oitenta e, sobretudo, a partir da primeira metade da década de 1990. A emergência da expressão agricultura familiar na literatura brasileira parece ocorrer, quase simultaneamente, em duas esferas distintas, no início da década de 1990. De um lado, no campo

\footnotetext{
${ }^{5}$ Prova disso é que a tradução de family farm, durante muito tempo, esteve incorporada no vocabulário dos estudiosos da Sociologia Rural como sinônimo de uma determinada categoria de agricultores, definidos como farmers. Para maiores detalhes, ver Loureiro (1987) e Lovisolo (1989), entre outros.
} 
político, a adoção da expressão parece estar relacionada aos embates que os movimentos sociais, especialmente o sindicalismo rural ligado à Central Única dos Trabalhadores (CUT), tiveram nas discussões acerca do espaço e o papel dos pequenos produtores rurais, especialmente os da região Sul do Brasil, no processo de integração comercial e econômica dos países que formam o Mercosul e, de outro, por intermédio de alguns trabalhos acadêmicos que passaram a buscar novos referenciais teóricos e analíticos, no referido período, e que introduziram a expressão.

O processo de integração dos países da região do cone sul da América Latina iniciou-se ainda no final da década de 1980 e culminou com a assinatura do Tratado de Assunción, em 1991. A partir deste tratado, foram estabelecidos vários acordos multilaterais, com o objetivo de ampliar a integração econômica e comercial entre o Brasil, a Argentina, o Uruguai e o Paraguai. Em razão das feições aparentemente excludentes desse processo, pois a real participação das organizações de pequenos agricultores estava virtualmente vedada, a expressão agricultura familiar surge como uma noção de convergência e unificadora dos interesses dos pequenos proprietários rurais que se julgavam não apenas preteridos politicamente da integração, mas afetados economicamente, uma vez que a abertura comercial ameaçava determinados setores da agricultura brasileira em razão das diferenças de competitividade de seus produtos. Além disso, a consolidação do Mercosul forçou as organizações de pequenos produtores a buscarem inspiração na formação de outros blocos (sobretudo o processo que levou à formação da União Européia), o que trouxe à tona um grande conjunto de informações sobre políticas para os agricultores familiares.

Como forma de unificar o discurso oposicionista, as entidades de representação dos agricultores que poderiam ser afetados pelas conseqüências da integração comercial e econômica, na época ainda desconhecidas, lançaram um discurso político que propugnava a proteção social, política e econômica dos agricultores familiares. ${ }^{6}$ Embora as ações empreendidas pelo movimento sindical tenham produzido resultados bastante fragmentados e de pouca repercussão política, pode-se afirmar que esse movimento constitui-se em marco decisivo para unificação do discurso em defesa dos interesses dos agricul-

\footnotetext{
${ }^{6}$ Durante esse período as principais propostas dos movimentos sociais de agricultores giravam em torno da idéia de "reconversão e reestruturação". Segundo Ilgenfritz da Silva e Braatz (1993, p. 4), a reconversão implica “[...]um processo de reestruturação competitiva de uma economia, de um setor, de um ramo de atividade, ou de uma unidade de produção, tornada mais vulnerável devido à integração ou à abertura de mercados. O termo reconversão está relacionado a modificações e redirecionamentos induzidos e/ou conseqüentes das mudanças estruturais dos mercados. Estas mudanças são originárias de três situações básicas: a) a abertura crescente e gradativa do mercado; b) a formação de blocos econômicos e; c) a modificação das relações de produção/mercados".
} 
tores familiares. Formou-se, portanto, uma nova categoria política que passou a congregar o conjunto dos pequenos proprietários rurais, os assentados, os arrendatários e os agricultores integrados às agroindústrias, entre outros. Através da noção de agricultura familiar, esses agricultores passaram a constituir uma nova identidade política e a orientar, de maneira distinta, as lutas sociais do movimento sindical rural, tal como expresso nos documentos mais recentes dessas entidades.

A partir da unificação do discurso político, os sindicatos e movimentos sociais do campo passaram a se identificar com a noção de agricultura familiar que, na verdade, congregava uma miríade de categorias sociais unificadas sob uma mesma denominação. Assim, as entidades de representação política dos pequenos agricultores vislumbraram a demarcação de uma base social numericamente bem mais extensa, o que ofereceria a possibilidade concreta de afirmação e ampliação de sua legitimidade política. Além disso, a legitimação crescente da noção agricultura familiar junto aos movimentos sociais também pode ser atribuída ao próprio enfraquecimento de outras denominações que eram usadas até então, como a de "trabalhador rural" ou "pequenos proprietários".

Assim, a adoção da expressão "agricultor familiar" parece ter sido encaminhada como uma nova categoria-síntese pelos movimentos sociais do campo, capitaneados pelo sindicalismo rural ligado à Confederação Nacional dos Trabalhadores da Agricultura (CONTAG), cuja expressão política havia se fragilizado ao longo da década de 1980. Em meados dos anos noventa assistiu-se a uma verdadeira efervescência desses movimentos, que produziram, inclusive, formas de manifestação política que perduram até hoje, como é o caso dos eventos anuais em torno do "Grito da Terra". Em face dos desafios que o sindicalismo rural enfrentava nessa época, tais como os impactos da abertura comercial, a falta de crédito agrícola e a queda dos preços dos principais produtos agrícolas de exportação, a incorporação e afirmação da noção de agricultura familiar mostrou-se capaz de oferecer guarida a um conjunto de categorias sociais, como os assentados, arrendatários, parceiros, integrados à agroindústrias, entre outros, que não mais podiam ser confortavelmente identificados com as noções de pequenos produtores ou simplesmente trabalhadores rurais.

Além disso, a afirmação da agricultura familiar no cenário social e político brasileiro está relacionada à legitimação que o Estado lhe emprestou ao criar o Programa Nacional de Fortalecimento da Agricultura Familiar (PRONAF), em 1996. Este programa, que em larga medida foi formulado como resposta às pressões do movimento sindical rural realizadas desde o início da década de 1990, nasceu com a finalidade de prover crédito agrícola e apoio institucional às categorias de pequenos produtores rurais que vinham sendo alijados das políticas 
públicas ao longo da década de 1980 e encontravam sérias dificuldades de se manter na atividade. A partir do surgimento do PRONAF, o sindicalismo rural brasileiro, sobretudo aquele localizado nas regiões Sul e Nordeste, passou a reforçar a defesa de propostas que vislumbram o compromisso cada vez mais sólido do Estado com uma categoria social considerada especifica e que necessitava de políticas públicas diferenciadas (juros menores, apoio institucional, etc.).

A segunda esfera, decisiva para consolidação da expressão agricultura familiar, refere-se ao pensamento acadêmico, especialmente das Ciências Sociais. Nesse caso, não se trata apenas de citar os autores e trabalhos que mais contribuíram para afirmação da agricultura familiar. Em primeiro lugar,é preciso indagar-se sobre as razões desse retardamento ou resistência à utilização da noção de agricultura familiar para caracterizar os grupos sociais com pequenas extensões de terra e que utilizam fundamentalmente o trabalho da família na execução dos processos produtivos.

Mesmo sem querer alongar em demasia uma resposta a esse questionamento, é preciso retornar à tradição dos estudos rurais produzidos pelas Ciências Sociais brasileiras nas últimas décadas. Esse parece ser o caso da noção de agricultura familiar, pois, embora alguns autores tenham utilizado a expressão em seus trabalhos, essa categoria jamais teve estatuto e significado semelhante à noção de family farming como nos Estados Unidos ou de exploitation familialle como na França. No Brasil, o que parece ter retardado e até mesmo impedido que a noção agricultura familiar ganhasse espaço no pensamento intelectual até o início da década de 1990 foi, de fato, o peso que as interpretações marxistas clássicas exerceiam sobre os estudiosos do mundo rural, desde as últimas três décadas.

Excetuando-se os trabalhos realizados no âmbito dos "estudos de comunidade" (aí incluindo-se os trabalhos sobre o messianismo) e daqueles inspirados pela diffusion research (difusão das inovações, migrações, adaptação de tecnologias, etc.) conduzidos por autores referenciais como Maria Isaura Pereira de Queiroz, no primeiro caso, e as pesquisas desenvolvidas em Programas de Pós-Graduação de orientação funcionalista da década de 1970 (IEPE/UFRGS, ESALQ/USP-Piracicaba, etc.), torna-se difícil arrolar uma produção sociológica sobre o rural que não tenha comungado com aquelas fontes teóricas. Não se trata aqui de diminuir a relevância da produção sociológica brasileira realizada fora do escopo do marxismo clássico, como, por exemplo, aquela inspirada no funcionalismo e na Rural Sociology norte-americana. O fato é que a contribuição dessas vertentes teóricas foi pouco profícua e influente no contexto brasileiro e significativamente inferior àquela de inspiração marxista.

Consultando-se algumas das principais revisões dos estudos rurais realizados no escopo das Ciências Sociais (e não apenas da Sociologia ou da Econo- 
mia), como Wanderley (1994), Tavares dos Santos (1990), Porto e Siqueira (1994), Gnacarini e Moura (1983),Asesp/Cebrap (1983) e Leite (1989/90), não é difícil perceber a ausência da categoria agricultura familiar como conceito. Essas revisões mostram que, de meados dos anos cinqüenta até o final da década de 1960, os estudiosos concentravam suas análises sobre a natureza das relações de produção no campo, reproduzindo, em grande parte, os argumentos clássicos do debate que, no marxismo, passou a ser a "questão agrária". Não é nosso objetivo retomar as posições de Caio Prado Júnior,Alberto Passos Guimarães e Inácio Rangel, mas apenas lembrar que, embora seguidores de diferentes enfoques teóricos, para estes autores, os pequenos proprietários, os arrendatários, os parceiros e outras categorias sociais estavam abarcados na noção de campesinato. Os camponeses eram identificados com os diferentes tipos de minifúndios, uma categoria que expressava a oposição aos latifúndios e que podia ser encontrada na estrutura agrária brasileira. Portanto, antes de ser uma categoria analítica, a noção de campesinato estava fortemente impregnada de um conteúdo político e ideológico. As características que os camponeses assumiam em cada situação social, bem como sua explicação teórica, variavam desde a idéia de que eram "resquícios feudais" até a proposição de serem formas de "assalariamento disfarçado". Tanto em um caso como no outro, restava apenas saber qual seria seu papel em uma sociedade com as feições do capitalismo brasileiro.

Na década de 1970, houve um deslocamento nesse debate e os proprietários de pequenos lotes de terra deixaram de ser identificados como "minifundiários" para tornarem-se "pequenos produtores", denominação esta ressaltada à medida que crescia a capacidade do Estado, naqueles anos, de propor e executar políticas para essas categorias, então também chamadas de "produtores de baixa renda". Esse redirecionamento, segundo Porto e Siqueira (1994), deveu-se às tentativas do Estado de fazer frente à proliferação de movimentos políticos identificados com o campesinato, como no caso das ligas camponesas do Nordeste e, ao mesmo tempo, à emergência de uma ideologia que pregava a modernização tecnológica desses estratos sociais, integrando-os ao processo de desenvolvimento do capitalismo na agricultura. Autilização do termo "pequena produção" contribuiu, portanto, para criar uma outra conotação, menos politizada e estigmatizada do que a de campesinato.

Entretanto, a utilização do conceito de pequena produção não provocou o abandono da noção de campesinato. Nesse sentido, seguindo a interpretação de Porto e Siqueira (1994), pode-se afirmar que o conceito de pequena produção tinha um caráter operacional, sendo diretamente associado aos grupos estudados, ao passo que o de campesinato ainda guardava um sentido teórico, indicando as suas características genéricas, como a forma de funcionamento, o uso da força de trabalho e as formas de gestão das unidades focalizadas. Em razão disso, em muitos estudos, observa-se uma superposição entre essas duas noções. Mas, o que me- 
rece ser ressaltado é que, nesse debate sobre a pequena produção e o campesinato, a influência do marxismo clássico revelou-se absolutamente dominante. Esseé particularmente o caso dos estudos sobre a "funcionalidade da pequena produção" no interior do capitalismo como Oliveira (1988), Martins (1975) e Graziano da Silva (1978), entre outros.

Certamente não se pode ignorar também que, a partir da segunda metade da década de 1970, surgiram no Brasil os primeiros estudos sobre camponeses e pequenos agricultores inspirados na "teoria da economia camponesa" proposta por Alexander Chayanov $(1974,1981)$. É o caso de trabalhos como os de Tavares dos Santos (1978), Heredia (1979) e Garcia Jr. (1983), entre outros. Contudo, embora esses trabalhos tivessem sido inovadores no sentido de transgredir de modo pioneiro as acomodadas fronteiras do marxismo clássico, sobretudo a sua vertente leninista, eles não romperam inteiramente com essa tradição. Assim, os camponeses analisados por Garcia Jr. e Heredia são descritos por sua relativa autonomia na forma de gestão da força de trabalho e do processo produtivo que se articula com o sistema econômico dominante. Por outro lado, o trabalho de Tavares dos Santos, além de demonstrar os mecanismos internos de gestão e funcionamento da economia camponesa, mostrou como esta se subordinava ao capital. Partilhando da idéia de que a relação dos pequenos produtores com o capital ocorria de forma subordinada, surgiram também outros trabalhos de referência obrigatória, como o de Wanderley (1985), embora deva-se enfatizar que esses autores não concordavam com a idéia de que os camponeses possuíam uma racionalidade particular ou caracterizavam-se por algum tipo de "especificidade".

Já na década de 1980, frente ao rápido processo de transformação tecnológica da agricultura brasileira, acrescentaram-se ao conceito de "pequena produção" as noções de "integração" e "exclusão" (Porto e Siqueira, 1994). Integrados seriam aqueles produtores que conquistaram elos de ligação com as agroindústrias e os mercados consumidores. Pequenos produtores excluídos, por sua vez, eram aqueles que haviam sido alijados do processo de modernização conservadora, como os sem-terra, posseiros, atingidos por barragens, etc. Do ponto de vista teórico, essas novas categorias acabaram reforçando a matriz teórica marxista clássica, que explicava esses processos a partir da idéia de que o capitalismo expandia-se para o campo de modo indireto, subordinando os pequenos produtores à sua lógica econômica e provocando um intenso processo de diferenciação social. Nesse sentido, os complexos agroindustriais representariam o processo de integração e subordinação da agricultura à indústria.

Além desses trabalhos mencionados, merece igual destaque o estudo realizado por Kageyama e Bergamasco (1989, p.55-73), que utilizaram como critério de classificação das categorias sociais presentes na estrutura fundiária bra- 
sileira a existência e magnitude do trabalho assalariado utilizado pelos estabelecimentos rurais. Esse trabalho representou um avanço significativo para as Ciências Sociais, porque apresentou, de forma pioneira, uma classificação da estrutura agrária brasileira, utilizando como critério a utilização de força de trabalho contratada ou, pelo contrário, a predominância do familiar. Dessa separação resultou a oposição entre estabelecimentos empresariais e familiares, idéia que se distanciou significativamente da polarização dos estabelecimentos rurais entre pequenos e grandes ou entre minifúndios e latifúndios, como na bibliografia mais antiga. Entre outras conclusões, o trabalho das autoras demonstrou que, na década de 1970, havia se formado na estrutura agrária brasileira um conjunto de estabelecimentos que eram pequenos em tamanho de área, mas que podiam ser classificados como empresariais, porque a maior parte da força de trabalho utilizada na propriedade era contratada. O que levou a afirmarem, textualmente, que "[...]as empresas familiares têm mais características comuns com as empresas capitalistas do que com os demais grupos familiares" (p. 63).

A partir desse trabalho, surgiram outras pesquisas cujo objetivo principal foi o de conhecer, de modo mais aprofundado, o caráter familiar dos estabelecimentos agrícolas e as formas de funcionamento dessas unidades (Lamarche, 1993, 1994-recentemente traduzido, 1999). ${ }^{7}$ Mais recentemente, já na década de 1990, uma pesquisa realizada pela Organização das Nações Unidas para Agricultura e Alimentação (FAO) e pelo Instituto Nacional de Colonização e Reforma Agrária (INCRA), cujo objetivo principal era estabelecer as diretrizes para um "modelo de desenvolvimento sustentável", sugeriu uma outra forma de classificação dos estabelecimentos agropecuários brasileiros, separando-os entre dois modelos: "patronal" e "familiar". Os primeiros teriam como característica a completa separação entre gestão e trabalho, a organização descentralizada, a ênfase na especialização produtiva e em práticas agrícolas padronizáveis, o uso predominante do trabalho assalariado e a adoção de tecnologias dirigidas à eliminação das decisões "de terreno" e "de momento" (intuitivas ou de senso comum). Já o modelo familiar teria como característica a relação íntima entre trabalho e gestão, a direção do processo produtivo conduzido pelos proprietários, a ênfase na diversificação produtiva e na durabilidade dos recursos e na qualidade de vida, a utilização do trabalho assalariado em caráter complementar e a tomada de decisões imediatas, ligadas ao alto grau de previsibilidade do processo produtivo (FAO/INCRA, 1994,p.2). Os estabelecimentos familiares foram ainda separados em três subcategorias: famili-

\footnotetext{
${ }^{7}$ A pesquisa coordenada por Hugues Lamarche constitui-se em um estudo internacional comparado, no qual o Brasil era apenas um dos países investigados (os outros foram Canadá, França, Tunísia e Polônia). Pelo lado brasileiro, participaram do projeto os pesquisadores Anita Brumer (UFRGS), Maria de Nazareth Wanderley e Fernando Lourenço (Unicamp) e Ghislene Duqué (UFPb).
} 
ar consolidada, familiar em transição e familiar periférica. Essa tipologia constituiu-se em suporte fundamental à principal política pública do Estado brasileiro de apoio direto aos chamados agricultores familiares e inspirou, posteriormente, vários trabalhos e estudos, entre os quais pode-se destacar Veiga $(1995,1996)$ e Bittencourte Bianchini (1995).

A partir dessa breve revisão, é possível, portanto, indicar algumas das razões que talvez expliquem por que a noção de agricultura familiar não encontrou espaço para desenvolver-se no ambiente acadêmico brasileiro, senão apenas a partir de meados da década de 1990. No Brasil, ao contrário do que ocorreu com a Sociologia de inspiração marxista nos países desenvolvidos, os estudiosos do mundo rural permaneceram, até recentemente, apegados à discussão sobre o sentido e o significado da "questão agrária brasileira". Entre as razões que podem ajudar a compreender essa trajetória está a hipótese apresentada por Konder (1988), que argumenta que no Brasil o marxismo somente foi incorporado ao pensamento acadêmico e sociológico a partir da década de 1950, depois de seu longo flerte com militantes e partidos políticos de esquerda, particularmente o PCB (também chamado carinhosamente de "partidão" pelos seus militantes). Esse itinerário pode, provavelmente, contribuir para se entender o forte apego de autores marxistas, identificados com a esquerda, como Alberto Passos Guimarães e Caio Prado Júnior (somente para citar os mais conhecidos), que são referência obrigatória nos estudos agrários nacionais, ao debate em torno do tema das características feudais ou capitalistas das relações sociais vigentes no campo. ${ }^{8}$

Conforme ressaltado em outro trabalho (Asesp/Cebrap, 1983), para esses estudiosos a questão agrária brasileira era tratada como um tema exclusivamente político e ideológico, no qual conhecer a natureza e as características das relações sociais de produção tinha por objetivo prioritário entender o "potencial revolucionário" dos grupos sociais rurais e de seu papel na luta de classes. Nesse sentido, o enfoque teórico perseguido pelos pesquisadores brasileiros inspirou-se fortemente em textos como "O Dezoito de Brumário de Luís Bonaparte", de Marx, "O Problema Camponês na França e na Alemanha", de Engels, e, sobretudo, os textos de Lênin e Kautsky. Conforme já mencionado por Abramovay (1992), uma leitura cuidadosa desses textos revela que a preocupação fundamental de seus autores era política e não acadêmica. No geral, tentavam responder a questão se era ou não importante aos partidos de

\footnotetext{
${ }^{8}$ Os recentes "artigos-depoimento" de Schwartz (1998) e Giannotti (1998) situam os temas em debate e o ambiente intelectual em que as discussões sobre a obra de Marx eram travadas em meados da década de 1950. Para maiores detalhes acerca do debate marxista brasileiro sobre a questão agrária, consultar Asesp/Cebrap (1983) e Kageyama (1993).
} 
esquerda de então apostar nas alianças políticas e na capacidade revolucionária do campesinato.

Em razão disso, as categorias sociais que hoje são denominadas de agricultores familiares eram descritas na época por uma miríade de nomes, como sitiantes, colonos, parceiros, meeiros, foreiros, etc.; interpretados à luz de conceitos como "resquícios feudais", "semi-proletários", "assalariados a domicílio", entre outros. Essa forma de compreender e explicar a natureza das relações sociais do campo, embora herdeira da tradição marxista clássica, impediu que o debate brasileiro sobre a questão agrária evoluísse e deslocasse seu enfoque para a contribuição propriamente epistemológica do marxismo à análise das transformações sociais, econômicas e culturais do mundo rural.

Afora essas limitações teóricas, impostas por uma determinada "leitura do marxismo" e do problema agrário, um dos raros estudiosos brasileiros que produziu uma crítica de natureza teórica às possibilidades de utilização do marxismo como referencial analítico para estudar o campesinato foi Abramovay (1992). A crítica deste autor ressalta um aspecto até então não considerado, afirmando que o problema do marxismo em relação à utilização dos conceitos de campesinato e mesmo de agricultura familiar é de natureza epistemológica. Por esta razão, vale a pena uma apreciação mais minuciosa de sua interpretação.

Ao demonstrar que a suposta dicotomia entre campesinato e agricultura familiar decorre muito mais das imposições teóricas dos paradigmas adotados pelos pesquisadores do que do ambiente empírico no qual essas formas sociais podem ser encontradas, Abramovay não apenas deu maior clareza ao objeto sociológico em questão (na forma de definir o objeto sociológico) como contribuiu decisivamente para sepultar, no interior das Ciências Sociais do Brasil, a falaciosa dicotomia em torno do caráter moderno/tradicional ou capitalista/camponês dos indivíduos que habitam e trabalham no espaço rural. Trazer ao conhecimento do público brasileiro a centralidade da forma familiar de produção, como característica principal da estrutura agrária dos países desenvolvidos, especialmente a partir do final da Segunda Guerra é, seguramente, um mérito inequívoco desse estudo.

A partir de cuidadosa análise, fundada em ampla bibliografia, sobre as contribuições teóricas dos "clássicos" do marxismo (Marx, Lênin e Kautsky), Abramovay ressalta que, para explicar a persistência do campesinato ou da agricultura familiar, no escopo desses referenciais, seria preciso recorrer não apenas à situação concreta em que esses analistas construíram suas obras como, também, entender seus referenciais epistemológicos. Assim, o autor concluiu que é um equívoco buscar uma explicação para essas categorias a partir de sua inserção na sociedade regida pela "lógica do capital", porque, para o marxismo, sua existência 
e reprodução sob o capitalismo seria impossível devido a uma incongruência de ordem conceitual e epistemológica:

É impossível encontrar na estrutura d'O Capital um conceito de camponês. Se, do ponto de vista marxista, é possível falar conceitualmente em classe operária e burguesia, campesinato é um expressão que não encontra lugar definido no corpo de categorias que formam as leis básicas de desenvolvimento do capitalismo [...] A impossibilidade de definir claramente a natureza e a origem de seus rendimentos demonstra que o conceito de camponês n'O Capital é logicamente impossível. A atividade produtiva que dá origem a sua reprodução não tem o estatuto de trabalho social e é neste sentido que o campesinato só pode se constituir naquele grupo de bárbaros de que falava Marx. As duas únicas classes que possuem a universalidade de incorporar nelas mesmas os elementos básicos de organização da socialidade contemporânea são a burguesia e o proletariado. (Abramovay, 1992, p. 35-36. Grifos no original)

Em face dessa limitação epistemológica do marxismo, Abramovay indicará que a compreensão teórica do campesinato reside na utilização do arcabouço analítico legado pelos estudos que a antropologia fez sobre as "sociedades camponesas". Já na introdução de seu trabalho, o autor aponta que a matriz analítica que julga pertinente à análise da produção familiar na agricultura pressupõe uma distinção entre o que é o campesinato e o que é a agricultura familiar. Somente com base nesta distinção é que se poderiam compreender as variadas formas de adaptação e inserção das unidades produtivas baseadas no trabalho familiar, tanto nas situações pretéritas como nas atuais:

A agricultura familiar é um fenômeno tão generalizado que não pode ser explicada pela herança histórica camponesa, de fato, em alguns casos existente: na verdade, o Estado foi determinante na moldagem da atual estrutura social do capitalismo agrário das nações centrais [...] Uma agricultura familiar, altamente integrada ao mercado, capaz de incorporar os principais avanços técnicos e de responder às políticas governamentais não pode ser nem de longe caracterizada como camponesa. (Abramovay, 1992, p. 19 e 21 - grifos no original)

Na opinião do autor, os camponeses podem ser entendidos como sociedades parciais com uma cultura parcial, integrados de modo incompleto a mercados imperfeitos, representando um modo de vida caracterizado pela personalização dos vínculos sociais e pela ausência de uma contabilidade nas operações produtivas. Já os agricultores familiares, são altamente integra- 
dos ao mercado, capazes de incorporar os principais avanços técnicos e de responder às políticas governamentais. Aquilo que era, antes de tudo, um modo de vida converteu-se numa profissão, numa forma de trabalho (Abramovay, 1992, p.22 e 127). Portanto, o que define o agricultor familiar moderno é o fato de ele estar inserido em uma sociedade na qual predominam relações capitalistas de produção e de troca. Assim, para Abramovay, a agricultura familiar, ao contrário do que pensavam os marxistas clássicos, ao invés de se decompor no processo de desenvolvimento do capitalismo, revela-se, na verdade, uma de suas características mais salientes.

Na segunda parte de seu livro, Abramovay apresenta farta argumentação para demonstrar as vantagens da agricultura familiar em cumprir o papel do abastecimento alimentar nas sociedades desenvolvidas. Seu objetivo principal é demonstrar que a produção familiar que se afirmou nesses países em nada se assemelha ao campesinato e tampouco à chamada pequena produção. ${ }^{9}$ Contudo, surge aí a interrogação maior, o que são estes agricultores familiares, a partir de que referencial teórico pode-se entender e explicar seu modo de reprodução?

A resposta de Abramovay a essas interrogações será relativamente paradoxal. De um lado, afirmará que a consolidação e a reprodução da agricultura familiar na estrutura agrária dos países desenvolvidos decorre fundamentalmente da intervenção do Estado e, de outro, que esta intervenção foi absolutamente indispensável, tendo em vista o caráter estratégico da segurança alimentar e, sobretudo, a base natural da qual continua a depender a produção agrícola. Essa resposta pode ser considerada paradoxal porque o próprio Abramovay utiliza-se de um recurso analítico do marxismo (que ele mesmo julgara incapaz para tal feito) para explicar a presença e sobrevivência dos agricultores familiares sob o capitalismo avançado. Esse recurso se sustenta na idéia de que as razões que explicam a persistência e o amplo predomínio da agricultura familiar na estrutura agrária dos países desenvolvidos devem-se ao fato de existir, nessas nações, um processo contínuo e estimulado de transferência das rendas da agricultura para o restante da sociedade através dos mecanismos de sustentação governamental dos preços. Esse procedimento interpretativo,

\footnotetext{
9 "O que se escamoteia sob o nome de pequena produção é o abismo social que separa camponeses de agricultores familiares - que vêm-se mostrando capazes não de sobreviver (porque não são resquícios de um passado em via mais ou menos de extinção), mas de forma a base fundamental do progresso técnico e do desenvolvimento do capitalismo na agricultura contemporânea [...]. Não se trata aqui, então, de explicar nada que se assemelhe à pequena produção, seja como sobrevivência do passado, seja enquanto setor capaz de realizar o jogo pelo qual o atraso técnico é supostamente compensado pelo fornecimento de trabalho abundante e sub-remunerado" (Abramovay, 1992, p. 211 e p. 213).
} 
como se sabe, é tributário das análises do próprio Marx para explicar as razões da persistência dos pequenos proprietários parcelários no Livro III de $O$ Capital..$^{10}$

Para Abramovay, a consolidação da agricultura familiar na estrutura agrária dos países desenvolvidos, após a Segunda Guerra Mundial, pode ser atribuída à opção do Estado por uma forma social que apresentava as melhores condições de cumprir uma função estrutural importante no modelo fordista, que era auxiliar no barateamento do custo de reprodução social da força de trabalho.

Antes de fazer do produto agrícola base imediata de acumulação capitalista e extração de mais-valia, os países centrais imprimiram ao setor um papel ainda mais importante: o de permitir que, pela redução dos custos de reprodução da força de trabalho, os orçamentos domésticos dos assalariados pudessem consagrar-se crescentemente a bens não-alimentares e sobretudo duráveis. (Abramovay, 1992, p. 227)

Nesse sentido, para esse autor, a persistência e a afirmação da agricultura familiar nos países desenvolvidos não deve ser atribuída às suas especificidades endógenas ou à sua herança camponesa. Além do papel do Estado, o outro fator determinante para alavancar e afirmar a agricultura familiar (e que justifica e reforça a intervenção estatal) nos países desenvolvidos deriva das próprias "particularidades naturais da agricultura", pois:

Operando com base em elementos vivos, a agricultura opõe obstáculos intransponíveis ao avanço da divisão do trabalho e por aí impede que o setor trilhe o rumo de outros segmentos econômicos no mundo contemporâneo. Enquanto depender de sua base biológica, a agricultura jamais será uma indústria. Esta limitação está na raiz da dificuldade que aí encontra a atuação de empreendimentos baseados no trabalho assalariado: o que é particular à agricultura não é a superioridade da produção familiar, mas, diferentemente dos outros setores da vida econômica, a inexistência nítida de vantagens decorrentes de tamanho das empresas repousando sobre o uso de assalariados. Isso não resulta de qualquer virtude da família enquanto agregado econômico e social, mas dos limites

\footnotetext{
10 "Embora pequeno capitalista, o único limite absoluto para ele é o salário que paga a si mesmo após deduzir os custos propriamente ditos. Enquanto o preço do produto o cobrir, cultivará a terra, e freqüentes vezes submetendo-se a salário reduzido, ao mínimo vital [...] Parte do trabalho excedente dos camponeses que lidam nas condições mais desfavoráveis é dada de graça à sociedade e não contribui para regular os preços de produção, nem para formar o valor em geral. Esse preço mais baixo, portanto, resulta da pobreza dos produtores e não da produtividade do trabalho" (Marx, 1890/1982, Livro III, Cap.47, p. 924).
} 
que a natureza impõe ao avanço da divisão do trabalho e, portanto, da inexistência de industrialização na agricultura. (Abramovay, 1992 p. 247)

O que se pode extrair, como conclusão da obra Paradigmas do capitalismo agrário em questão, que marca uma inflexão importante no debate sociológico brasileiro, é que a agricultura familiar, embora em alguns casos possa resultar da evolução das formas camponesas, se distingue dessa forma social pela sua inserção em um ambiente marcadamente capitalista. Em lhe sendo favorável esse ambiente, a agricultura familiar alcançará o cumprimento de uma série de requisitos, entre os quais fornecer alimentos baratos e de boa qualidade para a sociedade e reproduzir-se como uma forma social autônoma: nem capitalista, nem camponesa. Desse modo, para se saber quais as chances de sobrevivência dos agricultores familiares em sociedades capitalistas, é preciso compreender qual o seu papel e a posição que ocupam no "ambiente social e econômico" em que estão inseridos. Essa explicação, contudo, desconhece qualquer elemento endógeno, como, por exemplo, o papel da família ou do parentesco, como variável analítica para entender o funcionamento e a reprodução da agricultura familiar.

Em trabalho posterior, Abramovay parece ter percebido a necessidade de estabelecer uma definição conceitual mais objetiva da agricultura familiar, na qual reconhece a necessidade de considerar os elementos endógenos de funcionamento das unidades familiares, atribuindo-lhes, portanto, um papel muito mais destacado. Assim, em um trabalho de 1997, encontra-se a seguinte definição de agricultura familiar:

A agricultura familiar é aquela em que a gestão, a propriedade e a maior parte do trabalho vêm de indivíduos que mantêm entre si laços de sangue ou de casamento. Que esta definição não seja unânime e muitas vezes tampouco operacional é perfeitamente compreensível, já que os diferentes setores sociais e suas representações constroem categorias científicas que servirão a certas finalidades práticas: a definição de agricultura familiar, para fins de atribuição de crédito, pode não ser exatamente a mesma daquela estabelecida com finalidades de quantificação estatística num estudo acadêmico. O importante é que estes três atributos básicos (gestão, propriedade e trabalho familiares) estão presentes em todas elas. (Abramovay, 1997, p. 3)

À exceção do conjunto da obra de Abramovay, pode-se dizer que no Brasil as Ciências Sociais ainda não trataram o tema da agricultura familiar com suficiente amadurecimento para que se possa extrair um referencial analítico 
capaz de ajudar a elucidar, por exemplo, se a pluriatividade representa uma nova forma de agricultura familiar ou uma maneira diferenciada de garantia da reprodução social e econômica desses agricultores. Assim, em razão do interesse em estudar a pluriatividade sob a perspectiva da agricultura familiar e tentar colocar à prova as possibilidades de uso do referencial histórico e dialético na abordagem desse tema, acredita-se ser útil recorrer a outros autores e vertentes analíticas para mapear o estado da arte no que se refere ao debate contemporâneo em torno da agricultura familiar. Essa revisão se justifica no sentido de que a pluriatividade vem sendo apontada por vários estudiosos como uma das possíveis formas pelas quais as unidades familiares têm conseguido se reproduzir no campo.

\subsection{A CONTRIBUIÇÃODASOCIOLOGIADAAGRICULTURA}

Para demonstrar como o debate brasileiro sobre a agricultura familiar permaneceu fortemente conformado por uma determinada vertente do pensamento marxista, especialmente aquela apegada à noção de diferenciação social, nesta seção são introduzidos alguns autores informados pelo pensamento social crítico que, no entanto, produziram um conjunto de interpretações distintas sobre a permanência das formas familiares na agricultura contemporânea.

A partir de um conjunto selecionado de trabalhos dos autores que retomaram o aporte marxista para estudar a agricultura e as relações sociais no campo a partir de meados da década de 1970, tentar-se-á demonstrar quais foram as interpretações que lançaram acerca da persistência da agricultura familiar no desenvolvimento capitalista. Entre tais autores, aqui denominados "neomarxistas", encontramos os trabalhos de Susan Mann, Harriet Friedman, David Goodman, Claude Servolim e Henry Bernstein. Embora estes autores comunguem de uma mesma fonte de inspiração, os aportes teóricos propostos para analisar as formas familiares de produção na agricultura revelaram-se, por vezes, tão antagônicos que se torna difícil acreditar que todos foram influenciados pela mesma vertente teórica. Contudo, o que une essas diferentes perspectivas em torno de um mesmo enfoque teórico é a preocupação com a análise dos processos pelos quais o capitalismo penetra nas economias rurais, reestruturando a vida social e econômica dos indivíduos.

Antes de serem apresentados os principais argumentos teóricos e analíticos de cada autor sobre a agricultura familiar, cabe um breve comentário sobre o período histórico em que esses trabalhos foram escritos, o que talvez possa ajudar a explicar seu extraordinário impacto entre os estudiosos do mundo rural. Conforme se destacou em outro trabalho (Schneider, 1997), o debate sobre a 
agricultura familiar no desenvolvimento capitalista do pós-guerra está relacionado à crise da Rural Sociology de inspiração estrutural-funcionalista, cujos impasses surgiram a partir de meados da década de 1970. Nos Estados Unidos, onde esse paradigma teórico ocupava o posto de principal ferramenta dos estudos de comunidades rurais, esta crise parece ter sido mais intensa do que na França, onde os estudos realizados sob os auspícios dessa abordagem das collectivités villageoises, lideradas por Henri Mendras, somente perderam a vitalidade a partir do final da década de 1970.

Nos Estados Unidos, a crise da Rural Sociology impulsionou a aglutinação institucional de pesquisadores alheios ao funcionalismo e abriu espaços para novas vertentes do pensamento sociológico. Nesse contexto, a abordagem marxista passou a receber inúmeras contribuições com o objetivo de produzir avanços teóricos que fossem capazes tanto de sair do escopo das análises inspiradas no Livro III de $O$ Capital de Marx (e do "Dezoito de Brumário") e da abordagem leninista quanto de apresentar alternativas ao funcionalismo. Nos Estados Unidos, esse processo resultou, mais tarde, na emergência da Sociology of Agriculture, da qual alguns dos autores anteriormente citados tornaram-se seus principais expoentes.

Em segundo lugar, na década de 1960 e boa parte dos anos setenta, a teoria social de inspiração marxista, pelo menos no âmbito acadêmico, sofria forte influência da concepção estruturalista, da qual Louis Althusser, Nicos Poulantzas, entre outros, eram expoentes. Embora a influência dessa escola francesa possa ser relativizada, pelo menos no que tange à sua recepção nos países de origem anglo-americana, não há como desconhecer sua incidência sobre os estudiosos marxistas que se dedicavam ao estudo de temas relacionados aos países do Terceiro Mundo. A vertente estruturalista do marxismo influenciou autores como André Gunder Frank, Samir Amin, Immanuel Wallerstein e outros, cujas análises sobre a expansão do capitalismo e das relações entre países e regiões desenvolvidas e subdesenvolvidas constituíram-se no referencial analítico que passou a orientar a reflexão e as análises dos marxistas sobre o desenvolvimento capitalista. Esse arcabouço analítico inspirou vários estudiosos da agricultura e do mundo rural, que passaram a analisar de que modo determinadas formações sociais e econômicas, tais como os camponeses latino-americanos ou os agricultores familiares, apenas para citar duas, se inseriam na divisão social do trabalho e no modo capitalista de produção.

Nesse sentido, os trabalhos de Wallerstein sobre a internacionalização das relações econômicas, baseada na análise da dinâmica centro-periferia, influenciaram diretamente os trabalhos de Harriet Friedmann sobre a inserção dos agricultores familiares da América do Norte no sistema agro-alimentar internacional. Gunder Frank e Amin, por sua vez, defendiam a idéia de que havia uma re- 
lação estrutural de dependência entre os países e regiões capitalistas desenvolvidas e as subdesenvolvidas. Essa leitura influenciou uma série de estudos que buscavam caracterizar essa dependência entre formações sociais diferentes que operavam dentro de um mesmo modo de produção. Muitos estudiosos da agricultura e do mundo rural de inspiração marxista se utilizaram dessa moldura analítica para mostrar como determinadas categorias sociais (camponeses, por exemplo) se inseriam de modo dependente, desigual, articulado e subordinado à dinâmica do modo de produção capitalista.

Em terceiro lugar, a partir de meados da década de 1960 os estudiosos da agricultura de inspiração marxista passaram a ser confrontados com uma abordagem inteiramente nova das formas familiares de organização da produção agrícola. A partir da primeira tradução para língua inglesa da obra de Alexander Chayanov, The theory of peasant economics, em 1966, os marxistas, especialmente os de inspiração leninista, passaram a ser fortemente questionados em relação às suas explicações acerca da persistência da agricultura familiar sob o capitalismo. Os efeitos da publicação da obra de Chayanov em inglês sobre os autores marxistas podem ser acompanhados pelo intenso debate que então se instaurou, cujos principais trabalhos foram publicados entre 1975 e 1980 na revista inglesa Journal of Peasants Studies. Frente a isso, alguns autores como Mann, Friedmann e Goodman, para citar alguns dos mais influentes, produziram vários trabalhos que se constituíram em avanços significativos para o estudo das formas familiares e das razões de sua persistência sob o capitalismo, sem fazer apelo ao reducionismo teórico vigente.

\subsubsection{Os obstáculos ao desenvolvimento do capitalismo na agricultura e a persistência das unidades familiares de produção: as teses de Mann e Goodman}

Entre os estudiosos de tradição marxista que produziram inovações analíticas para explicar a persistência e a reprodução das formas de trabalho não tipicamente capitalistas na agricultura encontram-se as contribuições de Susan Mann e David Goodman. É claro que muitos de seus trabalhos foram produzidos em parceria com outros autores, mas uma análise mais aprofundada dessas contribuições logo revela o papel proeminente desses dois autores. Nos comentários que se seguem, serão apresentados seus pontos de concordância e de divergência e tentar-se-á demonstrar quais são os argumentos teóricos que permitem que ambos situem-se em um mesmo terreno metodológico que, no entanto, se desdobra em explicações distintas. 
Para Mann e Goodman, as razões que explicam a persistência de formas sociais não-capitalistas ou familiares na agricultura devem ser buscadas nas especificidades que caracterizam a agricultura, sobretudo pelo fato de que a terra e a produção agrícola impõem obstáculos naturais (de ordem biológica), que acabam limitando a exploração capitalista dos recursos naturais. Em razão disso, argumentam os autores, o processo de produção agrícola distingue-se radicalmente dos demais processos produtivos nos quais os fatores e os meios de produção podem facilmente ser recriados de modo artificial (a comparação, nesse caso, é com as atividades industriais). Ou seja, Mann e Goodman concordam que todas as tentativas teóricas de explicar a dinâmica do desenvolvimento do capitalismo na agricultura a partir do estudo das relações sociais (isto é, mostrar se são do tipo assalariadas, camponesas, etc.) não foram bem-sucedidas porque partiram de um pressuposto equivocado de que a atividade agrícola e a atividade industrial (assim como as demais) possuiriam processos de produção semelhantes.

Susan Mann, em trabalho assinado em co-autoria com James Dickinson, foi a primeira a apresentar uma argumentação teórica para mostrar que a persistência das unidades familiares no capitalismo não se devia nem ao equívoco da teoria de Marx, nem à capacidade de auto-exploração do trabalho familiar, nem à aplicação da tecnologia per se, mas "[...] esta anomalia explica-se pela lógica e pela natureza do próprio capitalismo" (grifo no original). ${ }^{11}$

A argumentação de Mann e Dickinson (1978, p. 471, grifo no original) se apoia diretamente em quatro aspectos da teoria de Marx: a) todos os argumentos estão ligados a teoria do valor; b) para Marx, segundo Mann e Dickinson, a "agricultura não é um todo monolítico" e ele próprio teria "chamado a atenção para a natureza peculiar de certas esferas da produção agrícola"; c) segundo os autores, Marx ressaltou que "o capitalismo é o modo de produção dominante, e, assim, é determinante"; d) conseqüentemente, a persistência da pequena produção agrícola deve ser desvendada não na dinâmica interna do trabalho familiar, mas nas necessidades da própria produção capitalista.

A partir da premissa, estabelecida por Marx, de que no capitalismo o valor de uma mercadoria é determinado pelo tempo de trabalho socialmente necessário para produzi-la, Mann e Dickinson enfatizam que a composição orgânica do capital ( $c=c c+c v$, onde "c" simboliza o capital; "cc", o capital constante e "cv", o capital variável) indica que somente o trabalho vivo cria valor. O trabalho vivo, que é dado pela utilização da força de trabalho em um pro-

\footnotetext{
${ }^{11}$ Em seu livro mais recente, Mann (1990,Cap. 2) enfatiza seu débito com Ariel Contreras (1977), que teria sido o autor pioneiro a retomar a análise de Marx, exposta nos Grundrisse, sobre as barreiras naturais ao desenvolvimento do capitalismo na agricultura.
} 
cesso produtivo, é essencialmente o tempo de trabalho necessário para produzir uma mercadoria qualquer. Entretanto, Mann e Dickinson destacam que o próprio Marx mostrou que esse tempo de trabalho pode ser diferente do tempo total necessário para a produção de uma mercadoria, porque " [...] nem todo o tempo em que o trabalho é mantido no processo de produção é necessariamente tempo de trabalho" (Marx citado por Mann e Dickinson, 1978, p. 471). Dessa premissa se depreende o núcleo da argumentação teórica dos autores, ao afirmarem que:

[...] a não-identidade entre o tempo de produção e o tempo de trabalho estabelece uma série de obstáculos à penetração capitalista em certas esferas da agricultura. Tal fato se torna claro quando observamos seu efeito na taxa de lucro, na utilização de capital constante e variável e nos processos de circulação e realização de valor. (p.473)

Segundo Mann e Dickinson, a diferença entre o tempo de trabalho e o tempo de produção das mercadorias na agricultura é facilmente observável em qualquer produto cultivado, pois em cada ciclo produtivo existe o período de preparo do solo, de plantio, de manejo e, por fim, de colheita, que são as fases da produção agrícola que requerem o uso de trabalho humano (ou por meio de equipamentos operados). Entretanto, esse tempo de trabalho efetivo é muito inferior ao tempo que cada cultivo necessita para seu desenvolvimento natural. O período em que as plantas e os animais estão sob os desígnios da própria natureza é um tempo de produção que o capital tem dificuldade de controlar integralmente, ainda que em certos cultivos ou criações ele tenha sido drasticamente reduzido, destacando-se os exemplos da criação de aves, suínos e hortifrutigrangeiros, entre outros.

Uma vez que o capital não consegue dominar integralmente o tempo de produção de uma determinada mercadoria, ele terá limitada a obtenção do lucro que achar aceitável por sua atuação naquela atividade, pois o fato de haver um gap entre o tempo de trabalho (capital variável) e o tempo de produção limitará a apropriação do valor-trabalho, que somente é gerado quando o trabalho vivo "entra em atividade". Esses obstáculos naturais à redução do tempo de produção ao tempo de trabalho, conforme destacado por Mann, vão estabelecer limites à velocidade de apropriação de valor, pois o objetivo de obter a maior taxa de lucro em menor tempo possível estará entravado pelo tempo em que a natureza estiver realizando o seu papel no desenvolvimento de plantas e animais.

Além de não conseguir controlar ou sincronizar essas diferenças de tempo, na agricultura o capital também se defronta com a dificuldade de dominar 
a circulação de mercadorias. Essa dificuldade reside no fato de que, após produzida, uma mercadoria agrícola qualquer entra no circuito comercial para ser trocada ou transformada de sua condição de "capital-mercadoria" em "capital-dinheiro", que é a fase final da produção de mercadorias e sem a qual não há a realização do valor. Na agricultura, o que dificulta esse processo e lhe impõe limites é o fato de que muitas mercadorias agrícolas são perecíveis ou possuem um prazo determinado para seu consumo, período de tempo que, em alguns casos, é bastante restrito. Também nesse caso, o capital encontra-se perante um obstáculo, pois os custos de circulação das mercadorias ficam ao encargo do capitalista, seu proprietário até o momento da troca, e, uma vez que a mercadoria se deteriore ou se torne imprópria para o consumo antes que entre em circulação (via troca), o prejuízo é integralmente de quem detem sua propriedade.

Em razão disso, Mann e Dickinson afirmam que várias atividades agrícolas se tornam um empreendimento de alto risco para o capital, fazendo com que determinadas atividades que possuem um tempo de produção extremamente longo, tais como os empreendimentos florestais, por exemplo, venham a ser atividades que o Estado passa a assumir ou a estimular mediante subsídios aos produtores. Outro aspecto destacado como uma consequiência desses obstáculos é o fato de que a presença de formas de trabalho temporário ou sazonal na agricultura podem ser igualmente explicadas por esses limites que a produção agrícola impõe à presença do capital.

Todas essas particularidades, segundo os autores, constituem-se em fatores que oferecem barreiras ao processo de rotação do capital (tanto na esfera da produção como da circulação) na agricultura, o que terá efeitos diretos sobre a obtenção da taxa de lucro. Em razão disso, o lucro obtido poderá ser menor que o esperado pelo capitalista, e até mesmo inferior que aquele que poderia ser obtido se investisse seus recursos em outra atividade. Portanto, a ausência das formas capitalistas usuais de produção na agricultura pode ser explicada pela pouca atratividade do capital por uma atividade em que a taxa de lucro tende a ser inferior àquela que poderia obter em outros domínios da produção capitalista. Nas palavras de Mann e Dickinson (p.478),

Ao contrário da indústria propriamente dita, onde o tempo de trabalho e o tempo de produção são mais ou menos coincidentes, em algumas áreas da agricultura a habilidade para manipular e variar o tempo de produção e o período de rotação é circunscrita pelas características naturais do objeto sendo produzido. Do ponto de vista do capitalismo, assim, tais considerações fazem com que certas áreas da produção agrícola sejam desestimulantes. Enquanto existirem constrangimentos objetivos, naturais, para a mani- 
pulação social do tempo de produção, o capitalismo avaliará tais áreas como de alto risco e de alto custo de produção. ${ }^{12}$

Entretanto, conforme foi frisado pela própria autora em trabalhos posteriores (1987a, 1987b, 1990), essa abordagem necessita ser utilizada no escopo de uma "análise social e histórica". O cerne da questão teórica de Mann não está na afirmação de que a responsabilidade pela persistência ou reprodução de formas não-capitalistas de trabalho na agricultura, especialmente as unidades familiares, deve-se aos obstáculos naturais impostos pela agricultura. Essa visão, segundo a autora, seria errônea, pois condicionaria o desenvolvimento do capitalismo a um determinismo natural. Para Mann e Dickinson,

[...] uma explicação baseada apenas na natureza não explica porque algumas esferas da agricultura se tornam capitalistas com relativa rapidez, enquanto outras esferas são caracterizadas por formas não-capitalistas. Em termos gerais, a inabilidade para controlar fatores naturais afeta todas as formas de produção agrícola, sejam empresas capitalistas, pequenas unidades de produção ou fazendas coletivas socialistas. Basear-se apenas na natureza é um argumento não histórico. Em contraste, Marx apresenta seus argumentos em termos da relação destes fatores naturais para as condições historicamente específicas exigidas pela produção capitalista. O que surge então como barreira natural é somente uma barreira às formas capitalistas de produção. (p.479, grifos nossos).

Assim, a persistência das formas familiares e não-capitalistas de produção na agricultura é explicada não pela sua dependência a formas mais complexas de exploração, mas, ao contrário, pela incapacidade do próprio capitalismo em superar, pelo menos até o presente, os limites naturais impostos pela produção agrícola (Mann, 1990, p. 33). ${ }^{13}$

Outro autor a apoiar-se no princípio de que no capitalismo a agricultura segue um rumo diferente do desenvolvimento industrial foi David Goodman.A questão central respondida por Goodman refere-se à forma pela qual o capitalismo se desenvolve na agricultura. Ao oferecer uma resposta a essa inda-

\footnotetext{
${ }^{12}$ No Brasil, os limites apontados por Mann e Dickinson para presença e expansão do capital na agricultura serviram de argumentos para Aidar e Perosa (1981), que demonstraram por que as unidades familiares seriam mais vantajosas para o capital agroindustrial. Nessa mesma linha, Nakano (1981) também enfatizou a debilidade do desenvolvimento capitalista da agricultura brasileira devido ao caráter oligopolizado dos capitais agroindustriais.

${ }^{13}$ Após a publicação do artigo seminal, de 1978, pelo qual Susan Mann e James Dickinson tornaram-se conhecidos, houve inúmeras críticas à sua tese original. Entre essas, cabe destacar a crítica persistente que Patrick Mooney $(1983,1988)$ dirigiu à "tese de Mann-Dickinson". Na opinião de Mooney, tal tese tinha basicamente dois problemas : um teórico e o outro de verificação empírica.
} 
gação, Goodman também considera responder ao aparente enigma acerca das razões que explicam a persistência da agricultura familiar na estrutura agrária contemporânea.

Em seus diversos trabalhos, Goodman rejeita a crítica de que a permanência e a reprodução das formas não-capitalistas ou familiares na agricultura seja a prova definitiva de que a economia política marxista não serve para explicar os caminhos seguidos pelo desenvolvimento do capitalismo na agricultura. Entre os autores neomarxistas, Goodman figura como um dos principais seguidores das teses desenvolvidas por Karl Kautsky, apresentadas no seu célebre livro intitulado A questão agrária.

Em mais de duas décadas de profícua e reconhecida produção acadêmica sobre a agricultura contemporânea e suas transformações, pode-se dizer que o cerne da abordagem teórica de Goodman está condensada no livro From farming to biotecnology, publicado originalmente em 1987 e traduzido no Brasil sob o título de Da lavoura às biotecnologias, em 1990. A tese defendida por Goodman tem a colaboração de John Wilkinson e Bernardo Sorj, dois renomados pesquisadores radicados no Brasil com os quais estabeleceu co-autoria em vários outros trabalhos (Goodman, Sorj e Wilkinson, 1985). Além desses, Goodman compartilhou vários de seus trabalhos com o cientista social inglês Michael Redclift, talvez seu principal colaborador, com vários trabalhos anteriores e posteriores à obra seminal de $1987 .{ }^{14}$

Na opinião de Goodman, Sorje Wilkinson (1990, p.1), portanto, “[...] a chave para compreender o caráter único da agricultura não está nem na sua estrutura social nem na dotação de fatores. Ao contrário, a agricultura confronta o capitalismo com um processo de produção natural, que não permite a sua transformação em um ramo da produção industrial" Em razão da incapacidade de remover diretamente essas limitações através da criação de um processo de produção unificado, "os capitalistas industriais reagiram adaptando-se às especificidades da natureza na produção agrícola. Dentro dos limites mutáveis definidos pelo progresso técnico, elementos discretos do processo de produção têm sido conquistados pela indústria” (p.1). Essa conquista, segundo Goodman, Sorj e Wilkinson, se dá pela apropriação, que é um “[...] processo descontínuo porém persistente de eliminação de elementos discretos da produção agrícola, sua transformação em atividades agrícolas e sua reincorporação na agricultura sob a forma de insumos" e pela substituição dos alimentos agrícolas por produtos industriais, o que é "[...] igualmente um processo descontínuo, mas permanente, de alcançar a produção industrial de ali-

\footnotetext{
${ }^{14}$ Entre esses trabalhos, cabe destacar Goodman e Redclift (1981, 1985, 1987, 1989 e 1991). Consulte-se também os recentes Goodman e Watts $(1994,1997)$.
} 
mentos via, primeiro, a redução do produto agrícola a um insumo industrial e, depois, sua própria substituição por componentes não-agrícolas" (p.2). ${ }^{15}$

A partir desses dois conceitos básicos, os autores estabelecem uma linha de raciocínio que os coloca próximo aos pressupostos apresentados por Mann, pois seu argumento central está baseado na idéia de que a persistência das formas de produção familiares ou não-capitalistas se deve a um problema estrutural relacionado à própria natureza da produção capitalista. Segundo os mesmos,

Para o capital, a limitação principal não é a autonomia (limitada) do fazendeiro, ou proprietário/operador, mas sim a sua incapacidade de eliminar os riscos, incertezas e descontinuidades intrínsecos a um processo natural ou biológico de produção. O corolário é que o grau de controle sobre o produtor direto (e, portanto, sobre a "forma" de produção) é secundário, em relação à falta de controle sobre a base orgânica do processo produtivo. É esse obstáculo intravável à produção capitalista, essencialmente técnico, e não a existência do arrendamento e da moderna propriedade de terras, o que explica a dinâmica de longo prazo da substituição industrial. Portanto, a tendência não é a eliminação do arrendamento pelo enfraquecimento de sua base material. É, pelo contrário, a de se eliminar a base material da agricultura em si porque ela à incompatível com o processo de produção capitalista. (p. 140)

Nessa passagem, são apresentados com clareza os argumentos contrários às teses de Marx, apresentadas no Livro III de $O$ Capital, no qual enfaticamente se afirma que a propriedade privada e a renda da terra que é cobrada para auferi-la é que se constituem em obstáculos ao desenvolvimento do capitalismo na agricultura. Nesse sentido, resgata-se assim a formulação original de Kautsky que afirmava que o capitalismo transformaria a agricultura através do progresso tecnológico, assim superando a própria barreira física da produção rural.

Essa avaliação do percurso seguido pelo capitalismo na agricultura, segundo Goodman e seus colegas, tem o objetivo de apresentar uma explicação histórica e dinâmica do processo de expansão das relações de produção capitalistas na agricultura. Ela permite que o debate marxista escape das infindáveis confusões decorrentes da utilização de noções como "formas de produ-

\footnotetext{
${ }^{15}$ Em trabalho anterior, Goodman e Redclift (1981 e 1987) utilizaram-se dos conceitos de "subsunção formal e subsunção real", retirados de Marx, para descrever as dificuldades do capital em apropriar-se integralmente do processo de produção capitalista e permitir a formação do valor. Em seu livro de 1987, os autores abandonaram essa perspectiva.
} 
ção" e "relações de produção" para explicar a presença das categorias sociais que compõem o mundo rural (camponeses, pequenos proprietários e outros). A argumentação desses autores distancia-se dessa perspectiva e é crítica de outras interpretações de origem marxista que buscaram explicar a natureza do desenvolvimento capitalista no campo a partir da análise das relações sociais engendradas por esse processo. Para Goodman, Sorj e Wilkinson (1990,p. 137, aspas no original),

[...] a questão das relações sociais específicas nos campos não atinge o "coração" da matéria. O problema central, ao contrário disso, é a corrosão industrial do rural, sendo variáveis-chaves a natureza e o grau pelos quais os sistemas biológicos de produção são reproduzidos no contexto industrial [...] a "agricultura" representa atividades crescentemente residuais que resistiram à sua transformação em processos industriais. À medida que a apropriação e a substituição prosseguem, mudanças nas relações sociais na agricultura dependerão do grau com que as atividades rurais remanescentes poderiam ser organizadas para manter e reproduzir grupos sociais diferentes. As relações sociais rurais, mesmo reproduzidas pelo capitalismo, são permanentemente erodidas e reconstituídas a medida em que a tecnologia reproduz a natureza em um quadro industrial.

Nessas circunstâncias, são desenhados dois cenários futuros em torno dos quais se acredita que avançará o processo de desenvolvimento capitalista na agricultura e as estruturas sociais que lhe dão sustentação. O primeiro refere-se a um movimento acelerado em direção a sistemas de produção contínuos, com um declínio paralelo no número de produtores à medida que cresce a especialização, intensidade de capital e escala de produção. No segundo cenário, a dinâmica principal surge dos métodos modernos de processamento de alimentos e de matérias-primas, os quais serão reforçados pelos avanços da biotecnologia (p.158-159).

É nesse contexto que Goodman prevê a possibilidade de que a agricultura em tempo parcial venha a desenvolver-se mais intensamente, fazendo com que os agricultores sejam transformados em "arrendatários virtuais ou reais", uma vez que boa parte das tarefas produtivas passe a ser realizada fora da propriedade por algum tipo de fornecedor. Segundo Goodman, “[...] o agricultor dará lugar ao 'bioadministrador' e a observação será substituída por software. A biotecnologia e as tecnologias da informação, portanto, andam de mãos dadas para criar um novo processo produtivo na agricultura" (p.163).

Embora se possa criticar a visão excessivamente fundamentada nos componentes tecnológicos do avanço dos processos produtivos agrícolas, não restam 
dúvidas de que os argumentos apresentados possuem o rigor analítico necessário para instrumentalizar uma determinada explicação para os rumos que o desenvolvimento do capitalismo seguiu na agricultura e, especialmente, para o papel secundário que, na visão dos autores, desempenham as relações sociais, sobretudo aquelas relacionadas à forma familiar de produção.

\subsubsection{As especificidades da agricultura familiar e a produção simples de mercadorias: as contribuições de Servolin e Friedmann}

Na maior parte das nações em que o capitalismo alcançou um elevado grau de desenvolvimento social e econômico, a agricultura repousa sobre a base de unidades produtivas nas quais a maior parte do trabalho provém da família. De modo geral, embora não por um mesmo caminho, foi a essa surpreendente constatação que chegaram vários marxistas a partir década de 1970. Esse fato, revelado à luz do próprio processo de desenvolvimento das forças produtivas ao longo do século XX, constituiu-se em grande desafio para a Sociologia da Agricultura, pois não apenas estava em contradição com a generalização das relações de assalariamento no campo, à semelhança do que se passava na indústria, esboçada por Marx em vários escritos, como também não revelava indícios de que os prognósticos de Lênin sobre a diferenciação social se instaurariam nos campos da Europa Ocidental.A questão com a qual passaram a se defrontar os marxistas, portanto, foi a seguinte: como o marxismo poderia retomar seu poder analítico e explicar o fato de que justamente nos países capitalistas mais avançados a agricultura permanecia sob a base do trabalho familiar?

Foi essa preocupação central que motivou alguns autores neomarxistas a buscar novos enfoques para demonstrar a pertinência do marxismo em responder a essas formulações. Esses autores acreditam que a análise das relações sociais (de trabalho e de produção) constitui-se no aspecto central para compreender os processos de "mercantilização" (commoditization) que se estabelecem em ambientes sociais e econômicos nos quais predominam as relações capitalistas. ${ }^{16}$ Em razão disso, alteram-se as formas usuais de reprodução social, que passam a ser mediadas pelo mercado, fazendo com que esses grupos sociais sejam submetidos a mudanças profundas. Outra característica desse grupo de autores é seu afastamento da abordagem de Lênin, que exercia forte influência nesse período. Por outro lado,

\footnotetext{
${ }^{16} \mathrm{Na}$ literatura internacional, a coletânea organizada por Long, Van der Ploeg, Curtin e Box (1986) tornou-se a principal obra de referência. Entretanto, uma análise detalhada desse trabalho revela que as idéias principais desse "debate" são inspiradas por Bernstein e Friedmann, que serão analisadas logo a seguir.
} 
não se pode esquecer que fatores alheios à vontade individual desses autores pioneiros, típicos de uma era, também influenciaram um ambiente mais aberto ao debate, com a "desestalinização", o relaxamento do antigo controle dos partidos comunistas sobre o pensamento científico e a sedução que o ambiente acadêmico tinha pelas idéias contestatórias. Maio de 1968, em Paris, ou as lutas pelos direitos civis nos Estados Unidos, entre tantos outros eventos da época, formaram o contexto privilegiado para inovações e deslocamentos teóricos no interior da tradição marxista.

É neste contexto que, em 1972, surge o trabalho L'absortion de l'agriculture dans le mode de production capitaliste, de Claude Servolin. Foi o primeiro autor a formular com pretensão analítica o conceito de produção simples de mercadorias, a partir da idéia de que no capitalismo a agricultura comportava-se como um "modo de produção específico". Talvez não seja possível estabelecer uma relação direta dos trabalhos de Servolin com aqueles produzidos na literatura neomarxista de língua inglesa, como os de Henry Bernstein e Harriet Friedmann. Servolin apoia suas principais formulações teóricas nas idéias de Althusser e rejeita a abordagem funcional-estrutural dos estudos do campesinato francês, liderados por Henry Mendras. Para ele, a produção mercantil simples deveria ser entendida como um modo de produção pré-capitalista que se articulava com o modo de produção capitalista mais amplo. Essa articulação entre modos de produção ocorreria através das trocas de mercadorias entre os pequenos agricultores e a economia de mercado, intermediadas pelas agroindústrias (Servolin, 1972,p.55). Essa coexistência interessaria ao capital, especialmente o de base urbano-industrial, porque os preços dos alimentos que abasteciam a classe trabalhadora tenderiam a permanecer baixos, o que permitiria a estabilização dos preços dos bens de consumo e a manutenção do poder de compra dos salários. Por outro lado, essa situação também interessaria ao Estado porque garantiria estabilidade econômica e progresso material à sociedade, além de dividendos políticos à classe dirigente. Por fim, esse modelo interessava, obviamente, aos agricultores, que passariam a garantir rendas cada vez maiores, em grande parte devido aos ganhos de produtividade obtidos, graças aos incrementos tecnológicos constantes.

Para Servolin (1989), a produção simples de mercadorias possuía vantagens comparativas em relação à produção capitalista, porque o agricultor familiar utiliza gratuitamente a força de trabalho de sua família, pois não se autoatribui salário fixo e não contabiliza seu tempo de trabalho com a precisão de um capitalista, o que faz com que o preço de seu produto seja infinitamente inferior ao praticado por uma empresa capitalista. Em um contex to no qual o Estado investe e subsidia o progresso tecnológico dos agricultores, a produtividade tende a aumentar e um número cada vez menor de agricultores produz 
volumes proporcionalmente maiores de alimentos. Nesse caso, os agricultores menos competitivos acabam sendo forçados a sair da atividade agrícola e absorvidos pelo modo de produção dominante, em outros setores econômicos.

Embora pioneiro, o debate sociológico marxista na França, em torno da explicação das razões da persistência da agricultura familiar sob o capitalismo não parece ter sido tão profícuo quanto o que foi praticado entre os pesquisadores de língua inglesa, especialmente britânicos. A partir da década de 1970, na Inglaterra e nos Estados Unidos, observa-se a emergência de várias abordagens novas, embora ligadas ao tronco comum do marxismo. Em parte, isso pode ser atribuído à reação de muitos estudiosos à tradução da obra fundamental de Chayanov, em 1966, para o inglês. Boa parte dos neomarxistas permaneceu fiel aos clássicos e rejeitou qualquer estatuto teórico e conceitual específico do campesinato (Ennew, Hirst e Tribe, 1977). Entretanto, outros não se limitaram a repetir os argumentos usuais e buscaram avançar teoricamente e responder ao desafio da persistência das formas familiares na agricultura. Esse foi o caso, por exemplo, de Harriet Friedmann (1978a, 1978b), que além de rejeitar a noção de campesinato, sugeriu a utilização do conceito de produção simples de mercadorias para explicar a dinâmica de reprodução das formas familiares sob o regime capitalista.

A contribuição de Harriet Friedmann é referência obrigatória no debate neomarxista acerca do desenvolvimento do capitalismo na agricultura e do papel das formas familiares de trabalho. O principal mérito de sua contribuição reside no fato de ter (re)colocado no centro do debate teórico o conceito marxista de "produção simples de mercadorias", utilizado originalmente por Marx para caracterizar as formas sociais que estão integradas apenas de modo parcial à divisão social do trabalho e aos circuitos de produção de valor, pois não conseguem realizar integralmente sua reprodução ampliada. Friedmann ganhou reconhecimento acadêmico pelo seu rigor teórico e metodológico, e especialmente por ter enfatizado que suas análises aplicavam-se à compreensão das formas familiares de produção que marcavam presença nas sociedades capitalistas avançadas. ${ }^{17}$

Ao contrário das teses que sustentam que a permanência das formas familiares de produção na agricultura devem-se às condições e aos obstáculos que a natureza impõe à penetração e desenvolvimento pleno do capitalismo na agricultura, Harriet Friedmann (1978a, 1978b) apresenta uma outra

\footnotetext{
${ }^{17}$ Não se pode esquecer que no mesmo período em que Friedmann buscava compreender o que se passava nas sociedades desenvolvidas, um outro grupo de pesquisadores se propunha a entender como o capitalismo se relacionava com as formas sociais não capitalistas como as camponesas, em países subdesenvolvidos. Neste grupo pode-se destacar os trabalhos de De Janvry (1981) e Vergopoulos (1977), seguidos, no Brasil, por Wanderley (1985), entre outros.
} 
interpretação sobre a presença e a reprodução das formas familiares de organização do trabalho e da produção na agricultura. A autora sustenta que a persistência das formas familiares de organização da produção e do trabalho não podem ser explicadas por sua associação à atividade agrícola (1986, p. 44). O que deve ser ressaltado, na sua opinião, não é o fato da agricultura ser uma atividade específica, mas porque em determinadas atividades econômicas, como no caso da agricultura, os processos produtivos se organizam com base em relações sociais específicas.

Para Friedmann, o que distingue a forma de atuação das empresas capitalistas na agricultura daquelas unidades produtivas que se organizam com base em trabalho familiar é a forma de organização do processo produtivo e as relações de parentesco. Nas unidades familiares, o trabalho é organizado com base em relações de parentesco e de gênero, porque é a própria família que trabalha, e a posse dos meios de produção não está separada de quem executa o trabalho. Nas unidades de produção capitalista, ao contrário, a força de trabalho é recrutada através do mercado de trabalho, via contrato de trabalho, à semelhança do que acontece com a aquisição das demais mercadorias necessárias ao processo produtivo. Já na produção mercantil simples os proprietários da força de trabalho e dos meios de produção encontram-se reunidos em uma única unidade e possuem relações de parentesco entre si, sendo, portanto, um tipo de combinação das formas anteriores. ${ }^{18}$ Contudo, além dessa diferença fundamental em relação à posse dos meios de produção (que no fundo diz respeito à situação de classe), o que faz a produção mercantil simples se diferenciar da produção mercantil capitalista lato sensu é o fato de que a última implica a obtenção de mais-valia e, portanto, a acumulação de capital, ao passo que a produção mercantil simples busca atender, prioritariamente, aos interesses de reprodução do núcleo familiar. Nos termos da autora,

\footnotetext{
${ }^{18}$ Para um entendimento sobre os termos utilizados pela autora reproduz-se, a seguir, as definições para: Forma de produção, utilizado como unidade mínima de organização da produção, sendo que na agricultura corresponde à unidade produtiva. Cada forma de produção é caracterizada por relações sociais determinadas e por um conjunto próprio de técnicas, estabelecendo relações específicas com unidades mais abrangentes de organização social, tanto com a formação social na qual se encontram inseridas quanto, naqueles casos em que estas relações são mais amplas ou mais restritas do que a formação social, com mercados específicos. Modo de produção, em seu sentido mais amplo, caracteriza complexos institucionais dotados de especificidade histórica, abarcando aspectos políticos, ideológicos, bem como estritamente econômicos da organização social. Reprodução ocorre quando o ato de produção não apenas resulta em um produto, como o trigo, mas também recria a estrutura original de relações sociais de forma que o ato de produção possa ser repetido da mesma forma (Friedmann, 1978b, p. 555).
} 
A condição básica para a reprodução da produção simples, portanto, é a contínua recriação da integridade da unidade familiar como uma unidade de produção e de consumo pessoal. As unidades familiares especializadas na produção de mercadorias são diferentes da produção capitalista na sua demanda interna de trabalho e na sua ausência estrutural de busca da maisvalia da produção. Essas diferenças estruturais afetam o significado da categoria renda no capitalismo, quando aplicadas às unidades familiares. A análise da produção familiar depende sobretudo da compreensão destas relações para se utilizar as categorias de renda de salários e lucro, que são, na perspectiva da reprodução, também categorias de custo. (1978b, p.559)

Para demonstrar empiricamente a validade desses pressupostos, Friedmann se propôs a aplicar em uma situação concreta a suposição que, segundo ela, deriva do próprio Marx, de que em determinadas situações o capitalismo poderia "coexistir" com formas sociais que realizam apenas a sua reprodução simples, o que não implicaria a formação de valor nem a acumulação de capital (especialmente a partir das discussões de Marx com Vera Zasulitch sobre os desígnios da "comuna rural" e as especificidades da transição para o capitalismo na Rússia). Segundo Friedmann (1978a, p.72), Marx teria utilizado o conceito de produção simples de mercadorias "puramente como um constructo lógico" para explicar as situações históricas em que formas sociais de trabalho conseguiam garantir a sua reprodução social (ou em termos marxistas, obtinham o necessário para reproduzir-se enquanto força de trabalho) sem, no entanto, contribuir socialmente para a formação de valor. Essa forma de utilizar o conceito de reprodução simples de mercadorias foi considerada por Friedmann excessivamente abstrata e destituída de conteúdo histórico real. Para corroborar essa opinião, Friedmann afirma que em $O$ Capital Marx teria utilizado o conceito de produção simples apenas com sentido heurístico para caracterizar uma fase hipotética e anterior à produção mercantil ampliada. Em razão disso, segundo a autora, era necessário empreender um esforço no sentido de que o conceito de produção simples de mercadorias permitisse abordar situações concretas em que não se verificava a inserção plena de determinadas formações sociais nos mecanismos de reprodução ampliada, tal como no caso dos agricultores familiares:

Este conceito deveria dar conta da lógica de reprodução da produção doméstica de mercadorias, analisando-a em seu contexto histórico. A reprodução de unidades mercantis familiares envolve a contínua reconstituição de uma conjunção aparentemente anômala de relações mercantis plenas que se estabelecem entre empresas, e de relações de parentesco desenvolvidas no interior destas empresas. Isto ocorre historicamente em mercados ple- 
namente desenvolvidos, não apenas no que diz respeito à produção de mercadorias pela força de trabalho familiar, mas, também, no que se refere à terra, aos meios de produção, artigos de consumo pessoal, dinheiro e, o que é mais importante, à própria força de trabalho. (1978a, p.73)

Nesse sentido, Friedmann propõem uma releitura com base na observação das transformações da produção mundial de trigo entre o período de 1873 e 1935, analisando as formas de produção e reprodução das estruturas produtivas, das condições diferenciadas de produção entre países e o papel das intervenções do Estado que afetavam essas condições. ${ }^{19}$ Nesse período, ressalta a autora, não obstante as diferenças geográficas entre as várias regiões produtoras de trigo no mundo, ocorreu uma transformação fundamental na organização social da produção de trigo: as empresas que produziam trigo com base nas relações capitalistas, de assalariamento, foram suplantadas pelas empresas que produziam com base em relações familiares e de parentesco (1978b, p.548) ${ }^{20}$ Friedmann verificou que no período posterior à Segunda Guerra Mundial a proporção de trabalhadores assalariados havia diminuído expressivamente na cultura do trigo, e em vários outros ramos agrícolas.

A autora ressaltou que, em uma situação em que os agricultores familiares operam como produtores simples de mercadorias, o recurso ao trabalho assalariado estaria diretamente associado ao ciclo de vida dos membros dessas unidades. Os agricultores contratam assalariados quando os membros ativos de suas famílias são em quantidade insuficiente (contribuindo para a reprodução geral da classe assalariada) ou podem eles mesmos se assalariarem fora de sua unidade para fazer frente a uma situação de dificuldade ou mesmo de ociosidade de força de trabalho (contribuindo, assim, para reproduzir as unidades familiares de produção mercantil simples). Por essa razão, para se compreender porque a integração aos mercados não implica o desaparecimento das unidades familiares é preciso considerar que esses agricultores atuam como produtores simples de mercadorias; ou seja, uma situação em que a propriedade dos meios de pro-

\footnotetext{
${ }^{19}$ Seu estudo é ilustrado com a análise do caso de "Cass County", localizado no Estado de North Dakota, definido por Friedmann (1978a, p. 73) como: "the heart of the specialized wheat production area of Nort American plains [...]".

20 "A emergência e a reprodução da produção simples de mercadorias de trigo nas últimas décadas do século XIX, e sua sobrevivência durante a crise de 1930, indica sua superioridade conjuntural sobre a produção capitalista. Esta superioridade deriva das condições técnicas que dirigem (governam) as taxas de terra e trabalho e das condições sociais que conduzem (governing) os custos de cada forma de produção dentro das formações sociais relevantes. As condições técnicas tornam a produção familiar viável. As condições sociais fazem sua competitividade ser superior em cada caso particular, mas a competição no mercado mundial faz estas condições serem sentidas pelo produtores mercantis de trigo em toda a parte" (1978b, p. 564).
} 
dução continua intimamente relacionada às relações de parentesco. Ao contrário dos assalariados permanentes, que dificilmente conseguem reunir recursos suficientes para se tornarem proprietários de um pedaço de terra ou mesmo de máquinas e equipamentos, os agricultores familiares que atuam na condição de produtores simples de mercadorias têm acesso aos meios de produção e sua condição de proprietários pode ser modificada em decorrência das relações de parentesco, como no caso do casamento ou da herança.

A formulação teórica de Friedmann está assentada no pressuposto de que, no capitalismo, é preciso distinguir a produção mercantil em geral (capitalist production) da produção mercantil familiar ou produção doméstica (household production). Ambas podem conviver em um mesmo sistema social e econômico, mas não estão assentadas nos mesmos princípios e mecanismos de operação. Segundo Friedmann, embora diferentes em sua forma interna e estrutural de funcionamento, tanto a produção capitalista quanto a produção mercantil simples só podem operar em um ambiente em que estejam totalmente integradas ao mercado de produtos, de preços e de custos de produção (1978b, p. 549). ${ }^{21}$ Segundo a autora,

Desde que a produção capitalista e a produção simples de mercadorias estejam plenamente integradas aos mercados de produtos, eles formam as condições de reprodução que derivam do próprio comércio [...] Para além destas similaridades, bastante gerais, as condições específicas de reprodução dependem, inteiramente, das relações de produção. Empreendimentos organizados com base no trabalho assalariado ou com base no trabalho familiar possuem custos de produção estruturalmente diferenciados. Cada tipo de custo é determinado de uma maneira específica. Estas distintas fontes de determinação prestam-se, por sua vez, a níveis diferenciados de manipulação por parte do empreendimento [...] A reprodução de relações assalariadas ou de uma unidade doméstica mercantil depende, portanto, de conjuntos diferenciados de condições objetivas e subjetivas que são estruturalmente determinadas (p. 556).

\footnotetext{
${ }^{21}$ Para Friedmann (p.548), "Produção capitalista, no sentido clássico em que é aqui utilizado, envolve duas classes, uma proprietária dos meios de produção e a outra de trabalhadores, ligadas por relações sociais de assalariamento, onde os primeiros compram a força de trabalho para operar seus meios de produção. Produção familiar (household production) envolve uma classe, que é ao mesmo tempo proprietária dos meios de produção e fornece a força de trabalho para operá-los. As relações que se estabelecem entre os membros não são de assalariamento, mas de parentesco. Quando a produção familiar é especializada e competitiva e os meios de produção e os recursos para subsistência precisam ser comprados, configura-se a produção simples de mercadorias."
} 
Os mecanismos de relacionamento entre as "formas de produção" (familiar) e o "modo de produção" (capitalista) podem levar à reprodução ou à transformação social. A reprodução, segundo Friedmann, ocorre quando os resultados do ato de produção permitem recriar a estrutura original das relações sociais para repetir a produção de forma idêntica à anterior. Uma vez que essas condições estiverem comprometidas, ocorrerá a transformação para uma nova forma de produção, que reterá aspectos socais e técnicos da forma anterior. O que importa reter, nesse resumo dos argumentos da autora, é o fato de que ao comparar a produção mercantil com a forma familiar de produzir, ela assenta nas relações sociais de produção o centro de seus argumentos para explicar as razões da persistência da agricultura familiar. Ou seja,

Como eu a defino, a produção simples de mercadorias refere-se à unidade entre propriedade e trabalho em uma economia caracterizada pela circulação geral de mercadorias e, portanto, pela separação entre capital e trabalho. Isto não se aplica a propriedades de trabalho familiar em formação sem o desenvolvimento de mercados de trabalho, de direito de propriedade e de capital, bem como de produtos. A característica principal da produção mercantil simples na agricultura é tipicamente o alto nível de tecnologia e investimento e um grande plano de concorrência, combinado com a divisão familiar do trabalho. (Friedmann, 1988, p.248)

Embora Friedmann considere que a abordagem de Chayanov seja equivocada e baseada em princípios neoclássicos, reconhece a pertinência de suas críticas acerca do uso inadequado de categorias da produção mercantil capitalista para tentar explicar as formas de produção familiares (1978b, p. 561; 1988,p.248). ${ }^{22}$ Além disso, embora não de modo explícito, apoia-se nas formulações chayanovianas para demonstrar que o processo de diferenciação intrafamiliar é uma variável-chave para compreender-se a dinâmica do funcionamento das unidades agrícolas familiares. Nesse sentido, o esforço de Friedmann pode ser considerado pioneiro, pois até então poucos autores de extração marxistas haviam ousado incorporar as relações de gênero, de poder patriarcal e o próprio ciclo de diferenciação etária das famílias como elemen-

\footnotetext{
${ }^{22}$ Pode-se resumir a crítica de Friedmann (1988, p. 248) a Chayanov com a citação da seguinte passagem: "[...] seu enfoque na inter-relação econômica e demográfica nas unidades familiares, tanto entre e através das gerações, é indispensável. O argumento chayanoviano é consistente com a produção simples de mercadorias na definição das dimensões internas da unidade de produção como ausências da categoria de lucro e a flexibilidade dos custos do trabalho [...] Para usar suas idéias de modo crítico, é preciso ir além de Chayanov para compreender a família como um locus de desigualdade e dominação e uma arena de lutas".
} 
tos explicativos de sua maior capacidade de competição, em relação a outras formas sociais (1986, p.46-47).

Com efeito, Friedmann reconhece a existência dos fatores naturais que dificultam a presença do capitalismo na agricultura, mas está convencida de que eles não oferecem obstáculos capazes de impedir que as relações capitalistas de produção se desenvolvessem no setor agrícola. Segundo ela, a verdadeira razão para a persistência das formas familiares se deve ao fato de que, no modo de produção capitalista, existem formas sociais de produção que, por razões históricas, o capital não conseguiu subordinar inteiramente à sua dinâmica. Esse é particularmente o caso das formações sociais nas quais ainda não ocorreu a dissociação entre a propriedade dos meios de produção e a força de trabalho, como a agricultura familiar.

Em trabalhos mais recentes $(1986,1988)$, a autora pondera que é exatamente a capacidade da família adaptar-se a um conjunto diversificado de situações que lhe são impostas pelo ambiente no qual se encontram inseridas que permite sua flexibilidade de adaptação ou reação. Como exemplo, Friedmann cita o crescimento do número de unidades agrícolas familiares nas quais as mulheres passaram a trabalhar em tempo parcial ou integral fora da propriedade (fenômeno denominado de pluriatividade), quer seja para atender demandas econômicas da família e da propriedade ou para buscar atender outros objetivos, como o reconhecimento social, o acesso a seguridade previdenciária, etc. Independente de quais sejam os objetivos que movem as decisões familiares ou dos seus membros individualmente, segundo a autora, o que permite que esses indivíduos possam optar entre uma ou outra alternativa é o fato de serem proprietários dos seus meios de produção e serem governados por relações de parentesco.

Sobre essa característica repousaria a chave para explicar os mecanismos que sustentam a competição intercapitalista e conduzem à busca de escalas cada vez mais intensas para elevar a produtividade agrícola. Friedmann não desconhece o papel do progresso técnico nessa relação, que pode elevar a taxa de lucro e a forma de garantir a reprodução social. No entanto, ela se apóia em seu estudo de caso para afirmar que os produtores simples de mercadorias tendem a optar com maior frequiência pela reprodução ampliada quando possuem filhos aos quais pretendem prestar ajuda para que se estabeleçam economicamente (1978a, p.88). Ou seja, as relações familiares e de parentesco são variáveis importantes a serem consideradas no processo de tomada de decisões dos agricultores, pois elas dão sentido e racionalidade às estratégias que os pais adotam visando ampliar os recursos e os bens disponíveis para deixar a seus filhos ou àqueles que seguirão com a propriedade.

Entre as críticas que foram dirigidas à perspectiva analítica de Friedmann, pode-se se destacar a de Goodman e Redclift (1985), a qual gerou uma rápi- 
da, porém interessante, polêmica entre os neomarxistas (Friedmann, 1986). As críticas de Goodman são ao mesmo tempo de cunho teórico e epistemológico. Em primeiro lugar, Goodman e Redclift rejeitaram o procedimento metodológico de Friedmann e afirmam que a autora substituiu a dialética pela utilização de tipos-ideais na sua análise da produção simples de mercadorias nos países avançados. Em segundo lugar, Goodman e Redclift discordam do conteúdo analítico do conceito de produção simples de mercadorias, afirmando que sua validade é apenas histórica e descritiva. Em razão disso, afirmam que há limites teóricos e empíricos para a utilização do conceito de produção simples de mercadorias.

Além disso, Goodman e Redclift apontaram outros três problemas na análise de Friedmann: o trabalho assalariado, a natureza da produção de mais-valia e as relações de classe. Primeiro, o confronto entre a base técnica e social da propriedade seria conjuntural, pois o uso de força de trabalho da família em lugar do trabalho assalariado somente ocorreria em certos momentos do ciclo demográfico da unidade familiar (quando os filhos já estão em idade de trabalhar e fazem parte da família). Para Goodman e Redclift, essa situação é excepcional, porque nos demais períodos as famílias seriam estruturalmente levadas a contratar assalariados para garantir sua reprodução, aspecto que teria sido negligenciado por Friedmann em razão de sua opção pelo uso heurístico do tipo-ideal. A segunda crítica relaciona-se à ausência de mais-valia na produção simples de mercadorias. Para Goodman e Redclift, é impossível que as famílias busquem somente a reprodução simples como seu principal objetivo (para Friedmann a reprodução ampliada se dá por motivações demográficas e culturais), porque esse pressuposto desconsidera a depreciação técnico-produtiva dos meios de produção e o próprio nível socialmente aceitável de renda das famílias que vivem em um ambiente da competição intercapitalista. Em decorrência dos dois problemas anteriores, Goodman e Redclift rejeitam a especificidade das formas sociais chamadas de produção simples de mercadorias, porque em um ambiente onde predomina a competição capitalista o uso do trabalho assalariado regular seria condição sine qua non para obter uma taxa de lucro e gerar as condições de reprodução da atividade (sobretudo para acompanhar o progresso tecnológico). Nessa situação, o uso permanente de trabalho contratado torna-se um pré-requisito estrutural, levando à separação entre trabalho e capital e permitindo, portanto, a exploração da mais-valia, esvanecendo-se, portanto, a especificidade da produção simples de mercadorias defendida por Friedmann. Para Goodman e Redclift, a questão central não está no fato do agricultor ser dono dos meios de produção e trabalhador ao mesmo tempo, mas na forma como ele usa o trabalho. Assim, a relação entre o dono dos meios de produção e 
os empregados pode ser de paternalismo, escondendo o que de fato é uma relação de exploração, portanto de classe.

Essas críticas reproduzem não apenas o debate entre esses dois autores, mas o confronto de perspectivas analíticas que serviram de instrumental de análise para os estudiosos da agricultura e do mundo rural nas décadas recentes, razão pela qual parece justificar-se sua apresentação nesse traba1ho. A reação de Friedmann às críticas de Goodman e Redclift é bastante objetiva e caracteriza-se por sua rejeição in totum aos argumentos dos oponentes. Para Friedmann (1986, p.189), “[...] a principal divergência com Goodman e Redclift é se é o setor produtivo ou a estrutura familiar a chave para compreender as relações sociais da agricultura". A autora opõe-se ao que chama de reducionismo de seus críticos que, segundo ela, restringem a complexidade da sociedade capitalista a uma falsa homogeneidade: a dependência ou não das relações de assalariamento. Além disso, rejeita a crítica de que falta conteúdo analítico ao conceito de produção simples de mercadorias e que tenha cometido equívocos na sua referência a casos empíricos. Entretanto, ressalta que não considera o progresso tecnológico como acidental, mas que, ao contrário de seus críticos, apenas o percebe como uma das características e "[...] não concorda que a agricultura está ligada unicamente à natureza, terra e espaço” (p.190).

\subsection{ANÁLISES TEÓRICAS RECENTES SOBREAAGRICULTURAFAMILIAR: O MODELO DE LAMARCHE EO DE GASSON E ERRINGTON}

Além dos referenciais claramente identificados com a abordagem da Sociologia da Agricultura neomarxista, o estudo da agricultura familiar e das suas estratégias de reprodução social sob o capitalismo também foi analisado por outras perspectivas teóricas, cuja importância para o conhecimento sociológico não pode ser ignorada. Em razão do reconhecimento que alcançaram entre os estudiosos, a seguir são tecidas algumas considerações meramente introdutórias sobre duas dessas abordagens alternativas, cuja principal característica é operar com base na construção de modelos de análise para interpretar a agricultura familiar.

Uma dessas interpretações alternativas que exerce considerável influência sobre os estudiosos brasileiros das formas familiares na agricultura é a proposta analítica desenvolvida por Hugues Lamarche $(1993,1999)$. Lamarche é atualmente um influente pesquisador das temáticas ligadas à agricultura familiar e suas transformações em sociedades européias, inclusive do Leste Europeu. Também não é demais lembrar que se trata de um dos seguidores da 
tradição iniciada por Henry Mendras, sendo, talvez o principal herdeiro de seu modelo de análise das sociedades camponesas e dos agricultores familiares na França.

Ao contrário das monografias de village, utilizadas por Mendras para descrever o funcionamento das sociedades camponesas nas décadas de 1950 e 1960, Lamarche sugere que o elemento essencial para análise da exploitation familiale agricole é o "enfoque tipológico", cujo objetivo deve ser o de "[...] analisar essas unidades familiares em seu conjunto, tendo em vista as diversas entidades que a estruturam. Compreender seu funcionamento significa colocar em evidência as diferentes lógicas em função das quais o agricultor determina suas escolhas individuais" (1993, p. 23) ${ }^{23}$ Esse enfoque se apoia na construção de um modelo heurístico de análise que é "[...] um eixo escalonado segundo o grau de integração no mercado, em cujas extremidades se encontram, de um lado, 'o modelo original' e, de outro, 'o modelo ideal' de unidade familiar. $\mathrm{O}$ 'modelo original'é o ponto de partida da análise, que se fundamenta no relato dos agricultores, mais ou menos conscientemente, sobre o tipo de unidade familiar a que pertenciam no passado: é o referencial do modo de funcionamento da exploração familiar" (p. 17). O "modelo ideal" é aquele que todo agricultor projeta para o seu futuro, em função dele organiza estratégias e toma decisões. Assim, a agricultura familiar moderna, como um modelo de organização das unidades familiares, constitui-se no resultado das transformações históricas por que passaram as formas camponesas.

Lamarche insiste que o eixo definido em torno dos modelos heurísticos de propriedades não segue uma trajetória linear, que se inicia em um ponto de partida até um ponto de chegada, pressupondo a evolução obrigatória das propriedades familiares: "não há qualquer determinismo em nosso propósito", chega a afirmar (p.20). Nesse sentido, podem coexistir diversos tipos de unidades de produção familiares, como as de tipo camponês ou as exploitations familiales modernes, cada uma com características próprias que dependem, em larga medida, dos "bloqueios" e das "rupturas" a que forem submetidas. Estas são duas noções-chave nesta abordagem: a situação de bloqueioé utilizada para compreender porque algumas unidades obtêm sucesso em suas trajetórias e outras não conseguem colocar em prática suas estratégias e alcançar o modelo ideal. As situações de ruptura ocorrem quando se verifica um antagonismo profundo entre o modelo ideal e o modelo dominante, preconizado pela sociedade, o que conduz à inviabilidade das unidades familiares. Assim, segundo Lamarche (p. 19), “[...] os agricultores organizam suas estratégias, vivem suas lutas e fazem suas alianças em função destes

\footnotetext{
${ }^{23}$ Para uma exposição dos elementos analíticos do modelo de Mendras, consultar o excelente trabalho de Wanderley (1990).
} 
dois domínios: a memória que guardam de sua história e as ambições que têm para o futuro. Suas chances de atingir o modelo ideal, ou simplesmente de se aproximar dele, dependerão da complementariedade de seu projeto junto ao que a sociedade elaborou para eles". Em síntese, o modelo tipológico de análise proposto por Lamarche (1994b, p. 2) se define da seguinte maneira:

A tipologia leva em consideração, ao mesmo tempo, as realidades estruturais e funcionais da unidade produtiva e suas dimensões sócio-culturais e ideológicas. Somente uma abordagem simbiótica destes dois aspectos da realidade permitirá uma análise dos modos de funcionamento destas unidades e uma avaliação de sua capacidade para gerir as dificuldades e dos diversos imprevistos que deverão afrontar [...] Uma vez determinados os tipos de unidades de produção, resta ainda avaliar sua capacidade de reprodução. Isto consiste em colocar em relação, num contexto local e global determinado, a situação concreta já descrita de cada tipo de agricultor e os projetos formulados por ele e sua família. Se um grupo de agricultores estima que o futuro de sua propriedade (ou seja, a continuação por pelo menos um de seus herdeiros) depende acima de tudo de uma melhora sensível de sua área de exploração, a possibilidade de realizar este objetivo dependerá, primeiramente, da aceitação de um de seus sucessores de seguir a mesma atividade do pai, e, após, da situação do mercado fundiário local (da possibilidade de compra, de locação, dos preços praticados, da obtenção de crédito, etc). O mesmo é válido para as outras condições exigidas [...] Todo estudo sociológico deve levar em conta estes diferentes níveis de observação e de análise, os quais são indissociáveis.

Para Lamarche, as propriedades familiares são unidades de produção agrícola nas quais a propriedade e o trabalho estão intimamente ligados à família. A principal característica dessas unidades é a sua diversidade, o que decorre, segundo o autor, "sem dúvida, da sua excepcional capacidade de adaptação" (1993, p. 15 e 21). Nesse sentido, a pluriatividade é interpretada como uma forma genérica de adaptação dos agricultores à sociedade englobante, pois constitui-se como "[...] um dos elementos das estratégias familiares, permitindo a sobrevivência ou a manutenção da propriedade em determinados casos, seu desenvolvimento ou a modernização em outros" (p. 109).

Essa proposta analítica de Lamarche parece atualizar o modelo teórico estrutural-funcionalista proposto por Mendras (1978). ${ }^{24}$ A diferença é que no modelo de Lamarche a estrutura social na qual se inserem os agriculto-

\footnotetext{
${ }^{24}$ Para um análise didática desse modelo, consultar Robert (1986). Uma avaliação crítica pode ser encontrada em Jollivet (1974).
} 
res familiares da atualidade não corresponde ao village ou às coletividades locais e a função decisiva dos mediadores (que era desempenhada, segundo Mendras, pelos notáveis do village) cedeu lugar a um conjunto de "lógicas" ou subsistemas, a saber: sistema de produção, sistema fundiário, sistema familiar, sistema de valores e sistema de representação, cada qual descrito pelo autor em uma segunda publicação da pesquisa, recentemente traduzida e publicada no Brasil (Lamarche, 1999) ${ }^{25}$ Nessa pesquisa, foram identificados dois mecanismos de funcionamento das unidades, as lógicas familiares e o grau de dependência, "[...] a partir dos quais diferentes modelos teóricos de funcionamento das exploitation foram definidos" (1994a, p. 55). ${ }^{26}$ De um lado, no que se refere às dimensões internas, existem as lógicas familiares que podem ser apreendidas pelo tipo de relação dos agricultores com a terra (fundiária), com o trabalho e com a reprodução da propriedade (herança) e, de outro, na esfera da relação das unidades com a sociedade global, existem os vários graus ou níveis de dependência, que podem ser tecnológicos, financeiros (crédito) ou de mercado, dos quais “[...] depende, em boa medida, a capacidade de adaptação das propriedades face as diferentes escolhas suscetíveis de comprometer seu desenvolvimento" (p.52). Portanto, a reprodução ou o sucesso dos agricultores dependerá, em larga medida, do grau de dependência e das escolhas da família em face às possibilidades e constrangimentos que a ela se apresentarem. ${ }^{27}$

Desse arcabouço analítico deriva uma compreensão das unidades familiares que funcionam como um grupo específico no interior da sociedade global (que é a estrutura), cujo futuro está fortemente condicionado pelas políticas agrícolas e as decisões do Estado. Como resultado geral da pesquisa internacional realizada em cinco países diferentes, inclusive no Brasil, Lamarche e os demais autores (p. 284) concluíram que um modelo ideal da agricultura familiar moderna reuniria as seguintes características fundamentais:

[...] a exploitation familiale moderne aparece claramente como um modelo que se situa, conforme nós imaginamos no nosso quadro de definição

\footnotetext{
${ }^{25}$ Segundo Lamarche (1993, p. 24), “A exploração familiar deve ser analisada em seu conjunto, ou seja: tendo em conta diversas entidades que a estruturam. Compreender seu funcionamento significa colocar em evidência as diferentes lógicas em função das quais o agricultor determina suas escolhas fundamentais. Estas lógicas se definem em relação a um determinado número de sistemas [...]".

${ }^{26}$ Os quatro tipos ou modelos teóricos que explicam o funcionamento das propriedades são: a unidade familiar moderna, a unidade empresa, a unidade camponesa ou de subsistência e a unidade empresarial familiar (1994a, p. 55).

${ }^{27}$ Segundo Lamarche (1993, p. 21), "atualmente, alguns agricultores estão em dificuldades, diríamos até na falência, porque não são mais capazes de pensar de outra maneira o seu modo de produzir e de viver".
} 
teórica de análise, entre o modelo paysan e o modelo entreprise, entre a tradição e a modernidade, entre o "modelo original" e o "modelo ideal". É então um modelo que, por definição, encontra a justificação de sua existência na lógica de integração das exploitations à economia de mercado e de adaptação permanente em função destas escolhas..$^{28}$

Outro modelo de análise das unidades familiares que gerou um expressivo reconhecimento foi aquele elaborado por Gasson e Errington, que ainda é pouco difundido nos círculos acadêmicos especializados do Brasil. Esse modelo parte do pressuposto de que as unidades produtivas agrícolas modernas possuem, ao mesmo tempo, características familiares e empresariais. O modelo proposto por Gasson e Errington (1993, p.18) busca evidenciar as relações entre a propriedade (farm) e o grupo doméstico (household) e possui seis características fundamentais:

1) a propriedade do empreendimento encontra-se combinada com o controle gerencial da mesma, que se encontra nas mãos de gerentes (business principals);

2) esses gerentes encontram-se vinculados por relações de parentesco ou casamento;

3) os membros da família (incluindo esses gerentes) costumam prover capital para o empreendimento;

4) os membros da família, incluindo esses gerentes, trabalham na agricultura;

5) a propriedade do empreendimento e seu controle gerencial são transferidos de geração para geração, ao longo do tempo;

6) a família vive na unidade produtiva).

Esse modelo representa, como os próprios autores salientam, um tipoideal da farm family business e não apenas uma definição operacional. Seu escopo privilegia as relações de parentesco, o controle administrativo e a transferência intergeracional das propriedades, relegando os aspectos da gestão do trabalho da família a um plano dependente dessas variáveis. As unidades familiares não se definem pelo tamanho ou exclusivamente pelo tipo de ocupação da força de trabalho, o que implica em uma ampliação de

\footnotetext{
${ }^{28}$ Esse modelo ideal de unidade familiar se conforma a partir de oito critérios de funcionamento, sendo quatro relacionados às lógicas familiares: a relação com a terra (entendida como patrimônio ou como fator de produção), o grau de utilização de trabalho familiar ou assalariado, a estrutura da família e seu papel para agricultura e a reprodução familiar da propriedade. Além disso, há quatro outros critérios para análise do grau de dependência, a saber: o grau de intensificação do sistema de produção, os aspectos financeiros, o grau de integração ao mercado e, por fim, o grau de dependência alimentar do exterior (Lamarche, 1994a, p. 265).
} 
enfoque, pois as unidades familiares não são necessariamente agrícolas ou de pequeno tamanho. Assim, o "negócio agrícola familiar" se sustenta sobre duas dimensões fundamentais: a família e o negócio agrícola (farm business). Para os autores, em uma situação em que terra e força de trabalho são cada vez menos os principais fatores da produção agrícola, torna-se necessário romper com a associação rígida entre família e agricultura. Nesse caso, para se compreender a produção moderna torna-se cada vez mais indispensável entender os mecanismos comerciais e administrativos das propriedades em face aos complexos agroindustriais.

Para Errington e Gasson (1994,p. 296, ênfase no original), o elemento central para caracterizar as unidades familiares não é apenas a alocação do trabalho, mas

[...] a combinação da propriedade comercial, o controle administrativo e a força de trabalho de uma família. A propriedade familiar e o controle mercantil podem ter implicações totalmente diferentes dessas que usam somente a força de trabalho da família. O conceito de unidade familiar mercantil (farm family business) é, portanto, muito mais amplo do que o de unidade familiar de trabalho (family-worked farm). A expansão mercantil não é restringida pelo trabalho que a família pode disponibilizar. Nesta nova definição, a família passa a ser vista como uma importante fonte de capital e de capacidade administrativa, bem como de trabalho.

Entretanto, a forma de utilização da força de trabalho é um aspecto central nesse modelo de análise. A questão crucial, como dizem Gasson e Errington (1993, p. 125) não é a presença ou não de trabalho assalariado, mas o fato de que pelo menos parte das relações de trabalho que ocorrem no interior da unidade são também relações familiares. Assim, a alocação da força de trabalho não vai depender apenas das demandas objetivas das tarefas a serem realizadas no processo produtivo, mas igualmente do ciclo demográfico em que se encontrar a família, que será responsável por uma certa flexibilidade que permita a ocorrência de períodos de maior ou menor capacidade de produção. Contudo, a influência desses elementos sobre o funcionamento da produção familiar está diminuindo na proporção em que essas recorrem à contratação de trabalhadores ou, o que é mais freqüente, à busca de atividades não-agrícolas fora da propriedade, como é o caso da pluriatividade.

Um dos objetivos desse modelo de análise, segundo seus autores, é colocar em evidência as possibilidades e os limites das unidades familiares no que se refere ao seu comportamento frente às situações distintas do cotidiano, bem como às decisões sobre as estratégias de longo termo. 
Para operacionalizar analiticamente esse seu modelo, é observada a relação com os capitais mercantis, os objetivos pretendidos com a venda de produtos e a utilização da moradia (como residência ou como local de trabalho), que são comparadas às formas não-familiares para se compreender suas vantagens ou restrições. Em todas essas situações, o que se analisa é a reação das famílias e suas atitudes perante os problemas e desafios que se impõem à sua reprodução.

Embora não seja o objetivo principal desta exposição, cabe salientar que o modelo proposto por Gasson e Errington vem recebendo críticas sobre a ênfase que confere ao papel da força de trabalho e sua alocação segundo os critérios antes já mencionados. Entre seus críticos, encontra-se o artigo de Djurfeldt (1996), que salienta as dificuldades de aplicação empírica da definição proposta por Gasson e Errington. Segundo Djurfeldt, esses limites decorrem do fato de que o modelo apresentado é formal e sua aplicação para o estudo de situações concretas se restringe ao caso da agricultura britânica contemporânea. ${ }^{29}$

Com a apresentação desses dois modelos de análise e interpretação da agricultura familiar pretende-se demonstrar que o estudo desse tema ainda se constitui em objeto importante para as Ciências Sociais (particularmente a Sociologia Rural), independente da matriz teórica a que se filiam seus autores. Além disso, acredita-se que os modelos apresentados poderão ser úteis aos estudiosos brasileiros das unidades familiares que, por alguma razão, preferirem utilizar abordagens distintas daquelas propostas pela Sociologia da Agricultura.

\subsection{CRÍTICAS E LIMITES DAS ABORDAGENS NEOMARXISTAS SOBREAGRICULTURAFAMILIAR}

A exposição das principais contribuições dos neomarxistas à compreensão das formas familiares e da estrutura agrária revela não somente o vigor analítico dessa abordagem como também sua relevância para a teoria social. De fato, conforme apontado, os neomarxistas norte-americanos e europeus foram bem mais além do que o debate brasileiro, que permaneceu fortemente "amarrado" à discussão da diferenciação social no campo. Seu esforço se expressa não apenas na revisão de aspectos centrais da teoria marxista mas,

\footnotetext{
${ }^{29}$ Nesse sentido, Djurfeldt (1996, p. 341) propõe um modelo que seja context free e capaz de incorporar outras noções para definir a agricultura familiar. Esse modelo se apoia em dois princípios: primeiro, deve-se separar as unidades familiares em unidade de produção (farm), unidade de consumo (household) e grupo doméstico ou familiar (family) e, depois, acrescentar como elemento-chave a noção de trabalho familiar para compreensão da reprodução dessas unidades.
} 
sobretudo, no aprofundamento e revelação de novos conceitos analíticos como, por exemplo, o de produção simples de mercadorias. Sob esse prisma, devese reconhecer que as abordagens neomarxistas conseguiram responder a um duplo desafio. Em primeiro lugar, lograram atualizar e mostrar a vitalidade e pertinência do marxismo para explicar e compreender os processos sociais e econômicos engendrados pelo capitalismo do século XX. Em segundo lugar, seu esforço recolocou o debate marxista sobre as relações sociais no mundo rural e na agricultura em um novo patamar, obtendo considerável sucesso na batalha contra as teorias rivais. Esse empenho, sobretudo a partir da década de 1970, trouxe uma contribuição significativa para o avanço do conhecimento científico das Ciências Sociais que se ocupam do estudo da agricultura e das populações que vivem nos espaços rurais.

Malgrado esse sucesso, o revigoramento da teoria social crítica, iniciado na década de 1970 pelos neomarxistas, ainda mantém deficiências e até mesmo limites que impedem avanços ainda mais significativos no estudo dos processos sociais agrários. É claro que essa avaliação possui um conteúdo subjetivo e varia em relação aos autores e enfoques, o que, aliás, parece salutar para assegurar a vitalidade deste aporte. Entre os limites desta abordagem, contudo, pode-se destacar o apego, por vezes excessivo, a um certo tipo de dedutivismo teórico, muitas vezes utilizado de modo dissimulado, que privilegia o papel dos elementos teóricos e conceituais em detrimento da pesquisa empírica e do trabalho de campo. Em alguns casos, essa proeminência assumiu um caráter essencialmente econômico, prejudicando a compreensão e identificação de outros aspectos das sociedades investigadas como a cultura, a religião, as tradições, etc. Segundo Buttel, Larson e Gillespie Jr. (1990), de certo modo, essa concepção dos neomarxistas se relaciona ao fato de terem insistido em perceber as formas familiares a partir do referencial da teoria do valor de Marx. Tanto as teses dos "obstáculos naturais" como da "produção simples de mercadorias" têm como núcleo central de sua argumentação o papel que as formas familiares desempenham no processo de formação do valor e acumulação de capital. Assim, para Mann e Goodman, as formas familiares persistem no capitalismo pela impossibilidade do capital tornar a agricultura um setor em que a taxa de lucro lhe seja satisfatória e atraente. Já para Friedmann, a persistência das formas familiares se deve à incapacidade histórica do capitalismo em separar os meios de produção da propriedade da terra em determinados grupos sociais. Em razão disso, muitos estudiosos rurais afastaram-se da Economia Política, buscando aportes teóricos que conferissem maior destaque a temas como os padrões de herança e transferência do patrimônio e as relações de gênero e de poder no interior das famílias. 
Além disso, os neomarxistas continuam a ser acusados de operar com conceitos excessivamente abstratos e orientados por uma pretensão generalista de universalizar explicações sobre diferentes grupos sociais (Llambi, 1990). A crítica que recebem fundamenta-se na idéia de que conceitoschave, como o de produção simples de mercadorias, utilizados por alguns de seus expoentes, não fogem à característica de serem recursos heurísticos formulados ex ante, que guardam semelhança com o procedimento hegeliano tão criticado por Marx, de "fazer descer do céu à terra" as abstrações do pensamento que são utilizadas para explicar a realidade.

Em segundo lugar, as análises neomarxistas são criticadas pelo fato de que suas explicações acerca da persistência ou transformação da agricultura familiar no capitalismo se produzem "de fora para dentro", pois afirmam que a possibilidade da agricultura familiar de se reproduzir não se deve à sua dinâmica interna de funcionamento, mas aos condicionantes da estrutura macro-econômica e social na qual está inserida. Nesse sentido, a agricultura familiar é entendida por alguns neomarxistas ora como uma anomalia, isto é, algo anacrônico em relação à divisão social do trabalho, que o capitalismo "tolera", em razão dos obstáculos que a natureza impõe ao seu pleno desenvolvimento na agricultura, ora como uma forma social que se "articula" ou consegue "coexistir" no interior de outras formações sociais e modos de produção. O que só acontece porque sua persistência beneficia o processo global de acumulação de capital, uma vez que a agricultura familiar produz alimentos a custos inferiores aos empreendimentos capitalistas dada sua condição de uso da força de trabalho nãoremunerada da família. Esse dedutivismo ainda hoje está presente nas abordagens sobre as estratégias de reprodução dos agricultores familiares, como a pluriatividade, que é interpretada como se fosse exclusivamente uma "estratégia de adaptação" das famílias e dos indivíduos ao mercado de trabalho rural não-agrícola.

Em terceiro lugar, os neomarxistas são alvejados pelas mesmas críticas dirigidas a Marx, que são expressas pela formulação de síntese apresentada por Abramovay (1992, p.34-35), de que, nessa abordagem, não há espaço lógico para categorias sociais, como a de campesinato ou a agricultura familiar, que não se inserem nas "leis básicas de desenvolvimento do capitalismo" Segundo essa formulação, o marxismo seria epistemologicamente incapaz de conferir estatuto conceitual a essas categorias, porque parte da premissa lógico-teórica que elas não encontram espaço para sua reprodução toda vez que a divisão social do trabalho passa a se orientar segundo as relações capitalistas de produção e reprodução. Segundo Marx, o agricultor familiar (ou os chamados "proprietários parcelários"), mantinha um caráter contraditório, pois era ao mesmo tempo dono de meios de produção e trabalhador sem, no entan- 
to, assumir a condição de capitalista. ${ }^{30}$ Para Abramovay, as reservas de Marx a essas categorias sociais não se resumiam à sua aversão política ou ideológica (expressa na famosa afirmação de que seriam "um saco de batatas"), mas, sobretudo, devido ao fato de que epistemologicamente, do ponto de vista da dialética, as categorias sociais que não podiam ser conhecidas por sua antítese (ou superação) e, portanto, não tinham raison d'être lógica. Pelo fato do camponês sintetizar a dupla condição de proprietário dos meios de produção e trabalhador, sua negação ou transformação era impossível de ser pensada a partir das categorias básicas da teoria marxiana.

Não obstante essas críticas, é possível afirmar que, do ponto de vista econômico, a teoria social crítica parece ter respondido satisfatoriamente a indagação acerca das razões que explicariam a persistência das formas familiares ao longo do século XX. Contudo, a excessiva preocupação dos neomarxistas com esses aspectos acabou tornando essa perspectiva analítica cada vez menos atraente aos cientistas sociais. Além disso, frente às mudanças que afetam o mundo rural e a agricultura familiar, em particular no período mais recente, com o crescimento das atividades não-agrícolas, a própria validade das proposições da Economia Política marxista passou a ser questionada.

A conclusão mais geral é de que a inserção econômica e produtiva dos agricultores já não é mais a única (e, em certos casos, nem mesmo a mais importante) forma de acesso dos indivíduos e das famílias rurais à divisão social do trabalho. Com isso, complexificam-se as relações sociais cuja natureza e dinâmica não podem mais ser explicadas apenas a partir das dimensões estritamente ligadas à produção material ou agropastoril. O que não significa, de modo algum, que deixe de existir a apropriação de valor na sociedade capitalista. Ao contrário, esse processo se diversifica e assume novas feições que perpassam as fronteiras espaciais e setoriais. A emergência da pluriatividade e das atividades não-agrícolas no espaço rural, como se verá mais adiante, parece se constituir em uma expressão desse processo.

Em termos analíticos, essa situação coloca em xeque o argumento de que, no capitalismo, a divisão social do trabalho se processa, par excellen$c e$, através do processo de acumulação de valor via extração do sobretrabalho, do qual decorre uma divisão espacial (rural versus urbano) e setorial (indústria, agricultura, comércio) da sociedade. Por essa via, pode-se questionar

\footnotetext{
30 “[...]duas pessoas: como proprietário dos meios de produção é um capitalista; como trabalhador, é seu próprio assalariado. Como capitalista ele paga a si mesmo salários e extrai seu lucro de seu capital; isto quer dizer que ele explora seu próprio valor-trabalho, e paga a si uma mais-valia, o tributo de seu trabalho para o próprio capital” (Marx, 1976, p. 408).
} 
a idéia, tão corrente entre enfoques mais ortodoxos, de que a expansão do capitalismo se reduz à instauração de um certo tipo de relação de produção, que provoca, inexoravelmente, a separação entre o trabalho e o capital (a separação de classes) e entre o campo e a cidade.

A perspectiva adotada neste livro parte do pressuposto de que, para se explicar por que as formas familiares sobrevivem nas sociedades modernas, não se requer, necessariamente, entendê-las pelo papel ou função que exercem no processo geral de acumulação de capital. É claro que isso não implica dizer que essas formas sociais permanecem isoladas, estranhas ou situadas à margem da divisão social do trabalho. Ao contrário, as formas familiares existem no interior das sociedades mais amplas, interagem com elas e sofrem diretamente seus efeitos e pressões. O que não ocorre, no entanto, senão em situações cada vez menos freqüentes, é a sua identificação com as posições de classe típicas do capitalismo, como assalariados ou burgueses, identificadas por Marx. Na sociedade contemporânea (por alguns chamada de pós-industrial ou pós-moderna), o processo de estratificação social tornou-se mais complexo, especialmente pelas novas formas que o trabalho vem assumindo, e uma explicação baseada na polarização de classes parece não ser mais suficiente, embora ainda seja fundamental para se entender as relações sobre as quais o capitalismo estabelece a regulação da sociedade contemporânea. Para o pensamento sociológico crítico, no entanto, essas transformações recolocam o poder explicativo da dialética, porque é justamente a ela que se deve recorrer para tentar entender o processo de articulação, integração e exclusão das formas sociais que não assumiram as características das relações capitalistas clássicas, que não apenas continuam a existir como parecem estar se difundindo. 


\section{CAPÍTULO 2 \\ Agricultura familiar e pluriatividade}

Neste capítulo será apresentado o referencial teórico e analítico a ser utilizado para o estudo da pluriatividade na perspectiva da agricultura familiar. Na primeira seção é descrita a trajetória da utilização das noções de part-time farming, multiple job holding e, mais recentemente, de pluriactivité. Pretende-se situar a controvérsia terminológica que ocupou a agenda dos pesquisadores nos países desenvolvidos e indicar a trajetória de alguns dos principais estudos que foram decisivos para afirmação do tema como um objeto pertinente à pesquisa social. Nessa revisão são expostos os pressupostos analíticos de autores e as razões que justificam a escolha de variáveis ou categorias de análise.

Na segunda seção discute-se a pluriatividade do ponto de vista teórico e conceitual, buscando-se absorver algumas críticas que estudiosos lançaram sobre os limites analíticos à utilização dessa noção, bem como a rejeição da idéia de que o fenômeno representava uma novidade e revelava uma face desconhecida das formas de ocupação e trabalho no meio rural. A revisão da literatura apresentada neste item, apoiada nas contribuições de autores como Marsden e Fuller, constitui-se no referencial teórico que orienta este trabalho. Assim, o estudo da pluriatividade é informado pela análise da forma de organização do trabalho e da produção em unidades familiares.

Na terceira seção do capítulo se ensaia uma definição operacional da pluriatividade e expõem-se elementos analíticos considerados importantes para compreender as características e traços principais das unidades familiares. Nessa seção, são esboçadas algumas considerações teóricas que pretendem indicar um possível diálogo da tradição marxista (na verdade, seguindo-se os avanços sugeridos pelos neomarxistas) com aspectos do enfoque microssociológico derivado do modelo proposto por Chayanov, especialmente a sua variável chamada de "diferenciação demográfica".

À luz de tais reconsiderações conceituais, na última seção do capítulo, sugere-se que o diálogo proposto deve utilizar como referencial teórico-conceitual a família rural como unidade de análise. Além disso, para fins de observação e interpretação, a família rural é dividida em unidade de produção e grupo doméstico, buscando analisar separadamente as atividades produtivas e a dinâmica da família. 


\subsection{DAAGRICULTURADETEMPO PARCIAL ÀPLURIATIVIDADE}

Até meados da década de 1980, os termos part-time farming e pluriactivité eram utilizados quase sempre como sinônimos pelos cientistas sociais. Até então, aceitava-se que a única diferença entre ambos estava relacionada ao fato de que o primeiro termo era de uso corrente entre os analistas de língua inglesa e o segundo era mais ligado à tradição acadêmica francesa. No entanto, mais do que meras diferenças etimológicas (que, em certa medida, expressam a dificuldade do diálogo intelectual entre essas duas tradições do pensamento), uma leitura mais atenta dos trabalhos que utilizam essas noções indica que elas incorporam diferentes interpretações de um fenômeno social que passou a se generalizar ainda na década de 1970, correspondente à diversificação crescente das fontes de renda e da inserção profissional dos indivíduos pertencentes a uma mesma família de agricultores.

Nos anos mais recentes, as diferenças semânticas e até mesmo as concepções teóricas acerca das noções mencionadas alteraram-se significativamente na literatura internacional, podendo-se, inclusive, perceber a emergência de um certo consenso em torno da noção de pluriatividade. No Brasil, malgrado alguns esforços, o debate sobre a pluriatividade ainda é embrionário. Embora alguns cientistas sociais tenham despertado para a relevância do tema e orientado algum esforço de pesquisa em sua direção, o que inclusive já se reflete no espaço que a temática vem ganhando em reuniões científicas, de maneira geral a pluriatividade ainda continua a ser tratada mais como uma curiosidade ou um fenômeno social inteiramente específico ou menor. Embora escassos, entre os resultados de pesquisas e publicações pioneiras no Brasil pode-se citar os trabalhos de Anjos (1995), Carneiro (1993, 1996a), Neves $(1995,1997)$ e Schneider (1994a, 1995). Mais recentemente, contudo, especialmente a partir de meados da década de 1990, José Graziano da Silva coordena um projeto temático, cujo objetivo consiste em analisar o que denominou de "novo rural brasileiro", em alusão à emergência expressiva das atividades rurais não-agrícolas no meio rural brasileiro. Após terem sido primeiramente realizados vários trabalhos sobre o Estado de São Paulo, o projeto (posteriormente apelidado sugestivamente de "Projeto Rurbano") ${ }^{31}$ assumiu proporções nacionais, englobando análises em diversos

\footnotetext{
${ }^{31}$ O Projeto Rurbano é um esforço de um grupo de pesquisadores de diversos Estados e instituições acadêmicas do Brasil, que pretende analisar as principais transformações ocorridas no meio rural brasileiro nas últimas décadas. Maiores informações estão disponíveis na home-page do projeto (www.eco.unicamp.br/projeto/rurbano).
} 
Estados. A partir dos esforços desse pesquisador, alertado inicialmente pelo surpreendente desempenho do emprego não-agrícola na Pesquisa Nacional por Amostra de Domicílios (PNAD) de 1992, o tema das atividades rurais não-agrícolas e da pluriatividade vem ganhando projeção nacional, podendo-se afirmar, inclusive, que o mérito da inclusão desse tema na agenda de pesquisas dos cientistas sociais brasileiros deve-se ao esforço do autor e de sua equipe.

Em razão do caráter ainda embrionário dos estudos brasileiros sobre a pluriatividade, considera-se oportuno o esforço de recuperar a trajetória do debate no período referido. Essa "moldura" sobre o estado da arte acerca do tema da pluriatividade orienta-se, inicialmente, pela retomada do itinerário histórico de termos, noções e conceitos para, a seguir, fixar-se no debate teórico e analítico. Esse esforço de revisão bibliográfica já foi tentado em outras oportunidades (Schneider, 1994) e seguirá fundamentalmente as pistas apontadas por outros especialistas como Fuller $(1984,1990)$, Marsden $(1990)$, Carneiro $(1993,1998)$ e Arkleton (1992).

A principal controvérsia em relação ao termo part-time farming refere-se à utilização do tempo de trabalho na propriedade por parte do indivíduo ou da família, ao passo que a noção pluriactivité refere-se à combinação de uma ou mais formas de renda ou inserção profissional dos membros de uma mesma família. No primeiro caso, é preciso estabelecer necessariamente como contraponto a noção de full time (tempo integral), utilizando-se como critério de diferenciação um determinado, embora arbitrário, corte de tempo de trabalho. Já a segunda expressão contém sua oposição na idéia de monoactivité, que se refere à forma de desempenho de uma atividade que, exatamente por ser "mono", traz implícita a idéia de que o indivíduo ou família ocupa a integralidade de seu tempo naquela atividade. Entretanto, como se verá a seguir, cada uma dessas noções tem uma trajetória analítica particular. Essencialmente, portanto, agricultura "monoativa" ou em "tempo integral", conceitualmente, são semelhantes e encerram o mesmo conteúdo e significado, mas seus opostos diferem substantivamente, como se verá a seguir.

Segundo a revisão empreendida por Fuller, acredita-se que o termo parttime farming tenha sido criado por Rozman (citado por Fuller, 1984, p.190) para diferenciar os agricultores que produziam apenas para subsistência daqueles que se ocupavam plenamente com a produção para a venda. De acordo com a periodização apresentada por Fuller (p.206), pode-se traçar uma linha divisória entre os trabalhos anteriores a 1975 e os posteriores a essa data. Antes de 1975, os estudos enfatizavam a viabilidade econômica e o caráter transitório e instável da produção em tempo parcial. Depois de 1975, os traba- 
lhos sobre o tema adquiriram estatuto sociológico e inicia-se uma fase de pesquisas marcadas pelo "enigma" em torno de conceitos e unidades de análise pertinentes ao estudo da agricultura de tempo parcial.

Essa periodização de Fuller também é reconhecida em outros trabalhos de revisão do estado da arte, como o artigo de Buttel e Larson (1982), que considerara que, até a década de 1970, o debate sobre a agricultura a parttime foi interminente e fragmentado. Em trabalho de síntese dessa trajetória, Fuller sugeriu que o termo part-time farming fosse substituído por multiple job holding farm household (MJHFH), o que permitiria reorientar a unidade de análise baseada exclusivamente no tempo de trabalho da unidade familiar. Nesse sentido, sugeria que os estudos sobre a MJHFH incorporassem três características fundamentais das famílias: a composição demográfica, o processo de tomada de decisão e as vontades e interesses dos indivíduos que compõem as famílias, considerando-se suas situações locais e históricas (Fuller, 1984, p.210).

Em trabalho mais recente, o mesmo autor indica que esse deslocamento da noção de part-time farming para MJHFH não deve ser entendido apenas em face dos limites analíticos que o primeiro termo impunha aos estudos empíricos (especialmente em razão da confusão entre a ocupação do produtor e a "função produtiva" da propriedade), mas também como uma decorrência dos novos desafios impostos nos anos mais recentes às próprias Ciências Sociais, particularmente a Sociologia (Fuller, 1990). ${ }^{32}$ Esses desafios teriam sido, inclusive, respondidos com a emergência de novos aportes teóricos para o estudo do rural e das transformações agrárias na década de 1980, como foi o caso da afirmação da Sociologia da Agricultura nos Estados Unidos (Buttel e Newby, 1980; Buttel, Larson e Gillespe, 1990) e da Economia Política na Europa (Marsden, 1992; Marsden, Munton e Ward, 1992 e Van der Ploeg, 1993).

Em outro trabalho, posterior, refletindo o debate da década passada, a diferença entre part-time farming e pluriatividade é apresentada de forma clara e objetiva por Fuller e Brun (1988), conforme as definições a seguir:

\footnotetext{
${ }^{32}$ A noção de MJHFH constituiu-se na principal inspiração analítica do Arkleton Trust Project, posteriormente substituída pela de pluriatividade.
} 


\section{Part-time farming: agricultura em tempo-parcial}

“[...] o termo 'part-time farming' em seu uso comum, até muito recentemente, tinha mais confundido do que clarificado a questão. O termo confunde a distinção existente entre a unidade produtiva enquanto uma entidade física (como um espaço) e os ocupantes desta unidade (a família ou a unidade doméstica), os quais decidem gestionar esta unidade de diferentes maneiras, inclusive combinando as tarefas agrícolas com outras atividades [...] Os termos part-time farm, part-time farmer e part-time farming têm sido utilizados de forma intercambiável, o que contribui para o surgimento de noções errôneas ou pressupostos equivocados associados a este fenômeno. É possível dizer que uma part farm é uma unidade produtiva que oferece, ou na qual é alocado, menos do que um ano completo de trabalho. O conceito de part-time farming pode ser utilizado, de forma mais precisa, para definir situações nas quais, devido ao tamanho físico ou a uma opção de gestão, a unidade produtiva é cultivada através do investimento de menos do que um ano completo de trabalho" (Fuller e Brun, 1988, p. 150, grifos no original)

\section{Pluriactivité ou pluriactivity: pluriatividade}

"[...] o termo procura focalizar as diferentes atividades e interesses dos indivíduos e famílias que vivem na unidade produtiva. Preocupa-se tanto com a reprodução social e a participação no mercado de trabalho rural como com a terra e as questões agrícolas. A pluriatividade implica uma forma de gestão do trabalho doméstico em que o trabalho agrícola encontra-se sempre incluído, podendo não ser, no entanto, uma atividade exclusiva ou mesmo a atividade mais importante. Outras atividades podem ser assumidas com o objetivo de sustentar ou de dar suporte à unidade doméstica, podendo também ser motivadas por considerações não-relacionadas à agricultura. A pluriatividade nos permite questionar o pressuposto de que a full-time farming é a norma e, portanto, algo bom, e de que a pluriatividade é um estado temporário ou um mal necessário no desenvolvimento econômico das unidades produtivas, das famílias ou das áreas rurais. A pluriatividade, entretanto, em seu sentido ideal, não é facilmente mensurável através das estatísticas oficiais disponíveis" (Fuller e Brun, 1988, p. 150, grifos no original).

Nesse contexto, o termo "agricultura em tempo parcial" foi substituído pela noção multiple job holding e este, posteriormente, pela expressão pluriatividade, numa referência analítica à disseminação do fenômeno da diversificação das atividades e das fontes de renda das unidades familiares agrícolas. Para Fuller, essa mudança ecoou na ampliação dos objetos de pesquisa das Ciências Soci- 
ais, que passaram a analisar temas como a ligação da agricultura com o sistema agroalimentar, as relações dos agricultores com os mercados de trabalho e os aspectos intrafamiliares decorrentes do novo padrão de relações sociais e econômicas entre homens e mulheres. Segundo Fuller (1990, p.362), “[...] esta reconceituação da pluriatividade da propriedade familiar também se reflete na mudança de direção dos valores nos anos oitenta: das questões econômicas para as ecológicas, das análises objetivas para as subjetivas, da pesquisa pura para aplicada, das disciplinas específicas para a multidisciplinariedade das pesquisas".

Ainda segundo o mesmo autor, foram três os fatores que contribuíram para o reconhecimento da relevância acadêmica e social da pluriatividade na década de 1980. O primeiro, de ordem conceitual, refere-se ao próprio uso da noção de part-time farming, que era impreciso e dificultava analiticamente a separação do trabalho do operador principal (chefe da propriedade) da função produtiva da propriedade. Existiam muitas propriedades nas quais o trabalho externo não tinha, de fato, relação com a redução das atividades produtivas agrícolas. Esses obstáculos levaram à substituição do termo, primeiramente pela noção de multiple job holding e, depois, pela de pluriatividade. ${ }^{33}$ Segundo, o "deslocamento etimológico" foi decisivo para a afirmação do fenômeno social como objeto de investigação acadêmica, o que ocorreu no âmbito do Arkleton Trust Project, que se constituiu numa iniciativa de pesquisadores dos países ligados à Comunidade Econômica Européia (CEE) para estudar em profundidade as unidades familiares rurais que combinavam a agricultura com outras atividades. Essa pesquisa representou, inegavelmente, um marco no estudo da pluriatividade, pois a partir dela passou-se a utilizar a unidade doméstica (farm household) como unidade de análise e não mais o chefe da propriedade ou o tempo de trabalho gasto em atividades não agrícolas. ${ }^{34}$ Finalmente, o terceiro fator que contribuiu para a consolidação da pluriatividade como tema de investigação foram os debates em torno da reforma da Política Agrícola Comum (PAC), iniciados na década de 1980, pois a crescente diversidade das ocupações do mundo rural não podia mais ser ignorada.

Esse processo de afirmação da temática no campo acadêmico culminou com a adoção da noção de pluriatividade como a melhor forma de apreender o fenômeno da multiplicidade de formas de trabalho e renda das unidades agrícolas. Segundo Fuller (p. 367) e também Newby (1987), o termo pluriatividade tem o mérito de incorporar tanto as características da noção de part-time farming (uni-

\footnotetext{
${ }^{33} \mathrm{O}$ trabalho de Cavazzani e Fuller (1982) é pioneiro na tentativa de procurar uma alternativa ao conceito de part-time farming.

${ }^{34}$ Mais adiante será retomada a definição de pluriatividade tal como é concebida nas pesquisas realizadas no escopo do Arkleton Trust.
} 
dades nas quais os membros moradores não utilizam todo seu tempo de trabalho nas atividades agrícolas) como da multiple job holding (unidades agrícolas que combinam múltiplas fontes de rendimento). Por isso, a expressão pluriatividade tem sido "[...] amplamente utilizada, porque abarca um conjunto de atividades que nem sempre são remuneradas com cash, mas com pagamentos em espécie, através da permuta de trabalho outros arranjos informais" (Fuller, 1990,p.367).Com essa definição, os estudiosos não apenas têm conseguido abarcar diferentes contextos em que o fenômeno se manifesta, desde os pequenos produtores não integrados aos mercados diversos, como também os grupos identificados com o campesinato, bem como examinar as relações entre os trabalhos formais e informais.

Desse modo, a noção de pluriatividade, apesar de polêmica, vem sendo utilizada para descrever o processo de diversificação que ocorre dentro e fora da propriedade, bem como para apontar a emergência de um conjunto de novas atividades que tomam lugar no meio rural. Nesses termos, uma das mais rigorosas definições encontra-se no trabalho de Fuller (p. 367):

A pluriatividade permite reconceituar a propriedade como uma unidade de produção e reprodução, não exclusivamente baseada em atividades agrícolas. As propriedades pluriativas são unidades que alocam trabalho em diferentes atividades, além da agricultura familiar (home-based farming). [...] A pluriatividade permite separar a alocação do trabalho dos membros da família de suas atividades principais, assim como permite separar o trabalho efetivo das rendas. Muitas propriedades possuem mais fontes de renda do que locais de trabalho, obtendo diferentes tipos de remuneração. A pluriatividade, portanto, refere-se a uma unidade produtiva multidimensional, onde se pratica a agricultura e outras atividades, tanto dentro como fora da propriedade, pelas quais são recebidos diferentes tipos de remuneração e receitas (rendimentos, rendas em espécie e transferências.

É justamente por causa dessa aparente "ubiqüidade posicional" que a noção de pluriatividade vem sendo questionada por vários autores, que reivindicam "uma delimitação mais rigorosa de um campo de observação tão difuso" (Carneiro, 1996b, p. 95). Embora essas críticas sejam pertinentes, parece ser logicamente impossível a associação direta do termo pluriatividade com seus similares "camponês" ou "pequeno produtor", que no sentido anteriormente descrito seriam quase sinônimos, tendo em vista as características históricas de cada um. Nesse caso, seguindo, aliás, uma recomendação da própria Maria José Carneiro, talvez seja mais apropriado admitir,enfim, que a pluriatividade "[...] é um termo de criação recente do vocabulário técnico, do qual o campo acadêmico se apropriou. Assim, a noção só ganha sentido se for relacionada com a política agrícola que estimulou a especialização da produção e do trabalho" (p. 10). Mais adian- 
te, contudo, ainda neste capítulo, será necessário retomar a discussão em torno da unidade analítica e conceitual que vem-se mostrando apropriada para estudar o fenômeno que até aqui definiu-se como pluriatividade.

\subsection{TEORIASOCIALEPLURIATIVIDADE: UMAREVISÃODODEBATERECENTE}

Nesta seção pretende-se discutir a bibliografia que relaciona mais diretamente a pluriatividade com os estudos sobre a agricultura familiar e o campesinato, bem como a evolução dos principais conceitos e noções que foram utilizados por pesquisadores como ferramentas interpretativas do fenômeno da combinação de atividades agrícolas e não-agrícolas pelas famílias rurais. Buscar-seá recuperar as principais fases e categorias analíticas que marcaram essa trajetória e, ao final, apresentar uma definição dos conceitos considerados adequados para estudar a pluriatividade sob a ótica do trabalho familiar, que se entende como a dimensão básica em torno da qual se organiza um determinado grupo social ligado por laços de parentesco e detentor de uma propriedade de terra em um espaço definido como rural.

\subsubsection{Atividades não-agrícolas e rendas complementares}

Uma vez que se concorda que o fenômeno atualmente denominado pluriatividade não representa uma situação inteiramente nova no modo de funcionamento das formações sociais e econômicas agrárias, pode-se recorrer a alguns estudos e examinar como seus autores interpretaram essa realidade. É nos trabalhos de Kautsky e Chayanov que se encontram algumas das primeiras referências aos "trabalhos acessórios" e às "outras atividades não-agrícolas", entendidos como formas complementares de obtenção de renda e inserção econômica de pequenos proprietários e camponeses.

Segundo Kautsky, o desenvolvimento do capitalismo na agricultura tende a seguir uma trajetória em que se dá sua "lenta e gradual" subordinação à indústria..$^{35}$ A persistência dos pequenos proprietários estaria relacionada à própria natureza do processo de desenvolvimento capitalista na agricultura, pois não obstante a superioridade técnica e empresarial da grande exploração, o que favorece a obtenção de taxas maiores de lucro pelos capitalistas, os pequenos continuariam a desempenhar o papel fundamental de for-

\footnotetext{
${ }^{35}$ Como enfatizou Kautsky (1980, p. 317 e 319), “[...] a indústria constitui a mola não apenas da sua própria evolução, mas ainda da evolução agrícola [...] A grande indústria passa agora a dominar. A agricultura deve obedecer às suas ordens, adaptar-se às suas exigências".
} 
necimento da força de trabalho para as unidades maiores. Segundo Kautsky (1980,p. 178), “[...] não devemos pensar que esteja a pequena propriedade territorial em vias de desaparecer, na sociedade moderna, ou que possa ser inteiramente substituída pela grande propriedade. A grande propriedade, por mais que repila todos os camponeses livres, sempre terá uma parte deles à sua ilharga, uma parte que ressuscita como pequenos arrendatários".

No entanto, ressalta a possibilidade de persistência das pequenas propriedades camponesas somente é admitida sob a condição de que estas venham a assumir uma função acessória e complementar à grande empresa, que exercerá seu pleno domínio no terreno da produção agrícola. Essa função acessória estaria relacionada à pouca disponibilidade de terra e às dificuldades de modernização tecnológica, o que restringe sua capacidade de concorrência e reduz a sua renda a níveis que obrigam essas pequenas unidades a buscar uma atividade complementar ou, então, a abandonar definitivamente o campo. De acordo com Kautsky (p. 194-206), existem três tipos de ocupações acessórias que podem exercer este papel:

a) o trabalho agrícola assalariado, mais conhecido como trabalho temporário, exercido nas grande propriedades em épocas de maior demanda por mão-de-obra, como nas colheitas;

b) a ocupação dos camponeses em indústrias a domicílio, o que em geral ocorre em regiões de pouca aptidão agrícola para consolidar uma agricultura competitiva, como era o caso de várias áreas na Alemanha e no restante da Europa, na ocasião de seus estudos. Apesar de ser menos eficiente do que a grande indústria urbana, a indústria a domicílio rural desfrutaria da vantagem de se apoiar na agricultura, o que lhe permite rebaixar os custos de produção, especialmente com a remuneração da força de trabalho;

c) finalmente, a própria fundação de indústrias no campo, que progride em função do avanço das comunicações (canais, estradas de ferro, telégrafos), o que também permite a emergência de trabalhos complementares para as famílias de pequenos proprietários.

Assim, afirma Kautsky (p.206), “[...] estas três espécies de trabalhos acessórios ao alcance dos pequenos camponeses não se excluem de modo algum. Podem existir simultaneamente, e freqüentemente coexistem". Portanto, pode-se dizer que a questão das atividades rurais não-agrícolas (ainda que não explicitamente nesses mesmos termos) aparece na obra de Kautsky não apenas como uma forma de reafirmação de seu argumento central, em favor da superioridade técnica da grande propriedade e do inequívoco processo de industrialização da agricultura (tornando-a um apêndice da indústria), mas, também, é possível perceber nessa análise que o autor divergia de Lênin e Engels e do próprio Marx, enxergando de modo radicalmente distinto 
os desígnios da estratificação social e econômica decorrente do processo de penetração do capitalismo no campo.

Fora do escopo do marxismo, outro autor a destacar a importância das "atividades rurais não-agrícolas" foi Alexander V. Chayanov (1974). Para se compreender a explicação chayanoviana sobre as razões que levavam os camponeses russos a buscar atividades complementares no meio rural será necessário situá-la em um quadro analítico mais amplo, que é o da "teoria da unidade econômica camponesa (UEC)". Nessa teoria, a idéia de equilíbrio entre trabalho e consumo ocupa um lugar de destaque no esquema analítico de Chayanov, embora a identificação dos elementos próprios ao comportamento da família, que é quem regula e operacionaliza a unidade de produção agrícola, seja um dos principais legados que ainda hoje permitem orientações interessantes. Segundo Chayanov, para compreender a família é preciso considerá-la sob três aspectos centrais. Primeiramente, deve-se estudar a família em seu ciclo demográfico completo, acompanhando-a desde o nascimento até a morte, o que implica relacionar a variação da utilização dos fatores produtivos (terra, trabalho e meios de produção) ao seu processo de diferenciação interna. Segundo, deve-se buscar entender o caráter teleológico do comportamento das ações da família, que organiza o funcionamento dos "mecanismos de equilíbrio internos" (Chayanov, 1974, p. 287). Essa racionalidade se orienta na direção da "utilização ótima de fatores" (terra, capital e força de trabalho), que é estabelecida a partir do tamanho da família e seu grau de auto-exploração em relação às condições objetivas dos meios de produção (p. 99). Por fim, em terceiro, a família resulta da composição e união entre a unidade doméstica (ou de consumo) e a unidade de produção, o que faz com que ela funcione como um todo indivisível e interdependente, especialmente no que se refere à gestão de suas rendas (p. 110-112).

Assim, Chayanov demonstra que o recurso às atividades não-agrícolas é variável e é determinado, primeiramente, pela variação do ciclo demográfico familiar. Nas fases em que as famílias possuem filhos pequenos ou quando resta apenas o casal de velhos (e, às vezes, um filho que se ocupa deles), a demanda por trabalhos não-agrícolas é menor vis$\grave{a}$-vis às situações em que as famílias ampliam sua capacidade de trabalho em face da maior aptidão dos filhos ao trabalho. Nesse caso, quando há subocupação da força de trabalho, o recurso às atividades não-agrícolas constitui-se em uma alternativa.

No entanto, apesar da busca às atividades não-agrícolas variar segundo o ciclo demográfico, isso não quer dizer, segundo Chayanov, que o tamanho da família seja o único critério que orienta a divisão familiar do trabalho 
entre atividades agrícolas e não-agrícolas. Nesse caso, é preciso considerar os elementos técnicos que influenciam a produção, porque a adoção de meios de produção mais eficazes poderia suprir a falta de braços antes mencionada. A divisão do trabalho familiar (entre atividades agrícolas e não-agrícolas) também se orienta "pelas condições econômicas gerais que se dão localmente" (Chayanov, 1974, p. 116). Assim, “[...] a suposição de que a busca de capital e principalmente terra induz a família camponesa a orientar parte considerável de sua mão-de-obra para as atividades não-agrícolas está perfeitamente correta na maioria dos casos. O êxodo para os ofícios nãoagrícolas se desenvolve, com efeito, de modo particular nas zonas de grande densidade de população" (p. 118). Essa afirmação, contudo, segundo o próprio Chayanov, exige que se estabeleçam dois condicionantes. Em primeiro lugar, o fato de que o desenvolvimento de atividades não-agrícolas está relacionado à irregularidade da distribuição do tempo de trabalho na agricultura, pois, em determinadas estações, como no inverno (no caso russo), a inatividade pode ser quase total; em segundo lugar, e isso é o principal, em muitas situações não é a falta de meios de produção o que origina os ganhos com atividades não-agrícolas, mas uma situação de mercado mais favorável para esse tipo de trabalho, no sentido da remuneração que se obtém pela força de trabalho camponesa, em comparação com aquela derivada da venda de produtos agrícolas (p. 118).

Trata-se [segundo o autor] de atividades artesanais e comerciais que fornecem uma remuneração muito mais elevada por unidade de trabalho. Com sua ajuda pode-se obter ganhos maiores com menores fadigas e a família prefere ajustar o equilíbrio básico entre consumo e desgaste de força de trabalho, principalmente através da ocupação em artesanato e comércio [...] Em outras palavras, podemos assegurar teoricamente que a divisão do trabalho na família camponesa entre atividades agrícolas e não-agrícolas (artesanato e comércio) é levada a cabo pela comparação da situação de mercado destes ramos da economia nacional. (p. 120)

Para Chayanov, o recurso às atividades não-agrícolas constituía-se claramente em uma estratégia de alocação da força de trabalho familiar frente aos condicionantes da unidade produtiva agrícola. Expressava, primeiramente, o sentido da racionalidade que a família imprime às suas atitudes para manter o balanço entre trabalho e consumo e garantir sua reprodução. Embora muitas vezes as atividades não-agrícolas sejam exercidas fora da propriedade, segundo Chayanov isso não compromete o caráter indivisível dos rendimentos familiares, que se organizam em um "sistema único de equilíbrio básico" que 
faz com que haja uma interdependência entre os ganhos totais da família (p. 112).

\subsubsection{Pluriatividade e dupla-atividade}

Além das abordagens teóricas que focalizaram as atividades não-agrícolas das famílias rurais como formas de buscar rendas complementares, que viabilizariam as estratégias de reprodução de tais unidades, há um segundo enfoque desse fenômeno que merece ser resgatado, dada a sua importância na literatura internacional e, até mesmo, por manter seguidores no Brasil.

Essa segunda corrente caracteriza-se por interpretar a pluriatividade ou o recurso às atividades não-agrícolas das famílias rurais como uma fase intermediária pela qual passariam as categorias sociais de agricultores que estariam imersos ou em um processo de proletarização ou de passagem de um estágio comunitário (identificado como rural e agrícola) para outro societário (identificado com o ambiente urbano e a industrialização). Embora os referenciais teóricos de ambos os enfoques sejam antagônicos (no primeiro caso, o marxismo, e, no segundo, o funcionalismo), as unidades familiares rurais que funcionam no modelo do part-time farming têm sido identificadas pelas categorias de working-peasants, ouvrier-paysans e, no Brasil, foram descritas como "colonos-operários".

Ambos os referenciais, que operam com essas categorias de análise, apoiam-se na idéia de que essas famílias encontram-se em uma situação transitória, que pode ser tanto de transformação completa (de agricultores a proletários) ou de passagem gradual e contínua (implícita aqui certamente a noção do continuum rural-urbano). No primeiro caso, a agricultura em tempo parcial é entendida como uma forma residual e transitória de categoria social na agricultura, que o processo de desenvolvimento do capitalismo no campo tenderia a remover. No caso das propriedades de tempo parcial, a transição ocorreria por dois lados: ou elas se tornariam propriedades full-time ou elas se "decomporiam", enquanto unidades produtivas, restando-lhes a venda da propriedade e o assalariamento. Mas também aparece a idéia de que a agricultura em tempo parcial poderia ser um fenômeno transitório e localizado em função das dificuldades circunstanciais (crédito e mercado), que atingem geralmente os pequenos agricultores, cujas propriedades situam-se em regiões de montanha ou em áreas agrícolas desfavorecidas. Passado o caráter conjuntural de uma dessas dificuldades, $\mathrm{o}$ produtor agrícola tenderia a se tornar um operador full-time e sair da condição de part-timer. Nesse caso, essa orientação teórica seguida pelos pesquisadores era a de que esse processo estava relacionado à crise da agricultura 
tradicional (entenda-se pequena produção) e à difusão das relações capitalistas de produção.

Nos países desenvolvidos, a abordagem da transitoriedade desenvolveu-se sobretudo a partir da década de 1950, em razão da retomada dos processos de deslocamento da população do campo para a cidade (Franklin, 1969). Nesse período, emergiu o debate em torno da double activité, que consistia na discussão das formas de combinação das atividades agrícolas com o emprego em atividades industriais pelos agricultores, em geral como assalariados. Segundo Carneiro, esta condição de "dupla-atividade" foi interpretada pelos estudiosos como uma prova de que os agricultores que operavam em tempo parcial (part-time farming) eram incapazes de se manter apenas com as rendas obtidas com a agricultura, o que fatalmente os levaria a abandonar sua atividade, tão logo novas possibilidades de saída definitiva do campo e de instalação mais segura na cidade se concretizassem (Carneiro, 1996b, p. 11). Esse debate foi particularmente intenso no caso francês, e talvez mesmo em boa parte da Europa, que ainda na década de 1960 registrava um significativo êxodo da população rural, motivado sobretudo pela expansão urbano-industrial e pelo rápido processo de modernização da agricultura.

A partir de meados da década de 1970, a noção de dupla-atividade passou a ser de uso corrente na Europa não apenas nos estudos que focalizavam os ouvrier-paysans (camponeses-operários), mas também sobre o movimento inverso, então chamado de neo-ruraux (neo-rurais), que caracterizava o movimento de "volta ao campo" de grupos de jovens que viam nessa atitude uma forma de oposição ou rebeldia ao status quo. Muitos desses "neo-rurais" sequer conheciam noções de cultivo agrícola, razão pela qual buscaram o espaço rural mais como um local de residência do que propriamente de trabalho.

No Brasil, os trabalhos sobre a dupla-atividade dos agricultores encontraram respaldo nos estudos pioneiros dos chamados "colonos-operários" realizados por Seyferth, nos anos oitenta, investigando os trabalhadores das indústrias têxteis de Santa Catarina que residem no meio rural $(1984,1987$ e 1992). A autora inspirou-se no aporte original de Franklin (1969), utilizando a tradução da expressão worker-peasant para descrever os colonos-operários como “[...] indivíduos nem bem camponeses, nem bem operários, que se identificam como colonos mas são trabalhadores da indústria - eis a realidade" (1987, p.37). Para Seyferth, seu status não é propriamente o de operários, e nem eles se consideram membros da classe operária, embora sua condição de industriário tenha reduzido bastante sua atividade agrícola. O que os distingue dos outros operários é o fato de possuírem outra ocupação - a lavoura, mesmo que voltada à subsistência 
- e, além disso, pertencerem a famílias que têm a propriedade das terras que cultivam (mesmo em pequena quantidade) e não residirem na área urbana. Paradoxalmente, são ao mesmo tempo assalariados, por um lado, e proprietários dos meios de produção, por outro (p.107).

Mais recentemente, nos anos noventa, surgiram outros estudos no Brasil, particularmente focalizando a região Sul, que utilizaram a noção de colonos-operários para caracterizar situações que hoje seriam denominadas de pluriatividade (conforme Anjos, 1995; 2001a, e Schneider, 1994a, 1999). Sobre os neo-rurais, a literatura brasileira é ainda mais escassa, podendose afirmar que os trabalhos de Giuliani (1991) e Teixeira (1998) estão entre os poucos que abordaram a presença da dupla-atividade no espaço rural. Esses trabalhos apresentam situações em que indivíduos da classe média urbana do Rio de Janeiro passaram a investir em diferentes atividades agrícolas (em geral, de alto valor agregado, como a produção de escargots) e não-agrícolas (pousadas e albergues) na região serrana fluminense. Entretanto, no caso dos estudos brasileiros, há uma especificidade que merece ser destacada. À exceção dos trabalhos de Seyferth, deve-se ressaltar que os outros autores citados não operaram com o enfoque da transitoriedade, antes mencionado. Na verdade, conforme menciona Kageyama (1998; ver também Anjos, 2001b), em sua recente revisão sobre o assunto, tratase de situações de pluriatividade das famílias rurais, ainda que seus autores nem sempre as interpretem como tal.

\subsubsection{A pluriatividade na teoria social contemporânea: a contribuição da Sociologia da Agricultura}

Após uma revisão da literatura que procura situar o debate sobre a pluriatividade no contexto das reflexões sobre o caráter e a natureza da agricultura familiar, é possível afirmar que os avanços teóricos e metodológicos mais significativos sobre tais temas localizam-se em torno de uma corrente do pensamento social denominada Sociologia da Agricultura (Newby, 1980; Buttel e Newby, 1980; Buttel, Larson e Gillespie Jr., 1990). Conforme destacado em outro trabalho, trata-se de uma abordagem relativamente recente na seara dos estudos rurais e agrários, cujas definições teórico-metodológicas são ecléticas e pluralistas, variando de enfoques neomarxistas a neoweberianos, cimentados por uma orientação genérica e relativamente vaga que seus próprios autores denominam "perspectiva crítica" (Schneider, 1997). Apesar das divergências internas de enfoques, os autores ligados à Sociologia da Agricultura tendem a concordar que a agricultura familiar encerra uma diversidade de situa- 
ções e possui múltiplas estratégias de reprodução social, conforme acentuam Buttel, Larson e Gillespie Jr. (1990, p. 110).

Algumas revisões recentes sobre a diversidade da agricultura familiar, como as de Moran, Blunden e Greenwood (1993) e de Kasimis e Papadopoulos (1997), identificaram clivagens de enfoques no interior de uma mesma abordagem teórica, como a Sociologia da Agricultura. Segundo esses autores, o debate recente experimentou três momentos. O primeiro foi marcado pelo debate centrado na natureza e no sentido da agricultura familiar, recebendo uma inflexão decisiva a partir dos estudos de Friedmann (já discutidos no primeiro capítulo). O segundo teria sido marcado pela reação a esses trabalhos, derivado das contribuições de Mann e Dickinson, Goodman, Mooney, Long, Van der Ploeg, Curtin e Box, também já analisados anteriormente. O terceiro e último momento, segundo os autores, seria o atual, com o objetivo de superar a discussão teórica, entendida como restrita, sobre a agricultura familiar, tema que dominou a literatura na década de 1980, e "[...] redefinir as abordagens da Economia Política no sentido que se tornem aplicáveis aos estudos interdisciplinares e que superem os limites das fronteiras nacionais, abrangendo as complexidades das economias rurais e superando as preocupações com as teorias dedutivas e unilineares do desenvolvimento agrário"(1993, p. 25). Já Kasimis e Papadopoulos (1997) caracterizaram o debate recente da Economia Política de forma semelhante aos argumentos principais de Buttel, Larson e Gillespie Jr., afirmando que ele foi polarizado entre aqueles que consideravam a agricultura familiar como uma característica permanente da agricultura moderna (portanto, sua persistência era estrutural) e aqueles que a consideravam como um fenômeno transitório, que antecedia ao domínio do sistema agroindustrial (1997,p. 211).

Embora sob um mesmo referencial, é inegável que há divergências notáveis entre os autores da Sociologia da Agricultura que trabalham com o tema da agricultura familiar e, mais especificamente, com a pluriatividade. Trata-se, na verdade, de distintas perspectivas analíticas no estudo de um mesmo objeto. Entretanto, conforme já frisado, apesar dessas discordâncias, acredita-se no potencial teórico-conceitual da Sociologia da Agricultura para o estudo da pluriatividade como uma das características peculiares à forma familiar de organização do trabalho e da produção na agricultura. Nesse sentido, compartilha-se amplamente da síntese de Kasimis e Papadopaoulos (1997,p. 213) acerca dos resultados e das conclusões genéricas produzidas pelo debate recente da Sociologia da Agricultura, quando interpretaram a agricultura familiar no mundo moderno: 
A unidade de produção agrícola familiar constitui-se, no sentido mais amplo do termo, enquanto um conjunto heterogêneo de relações entre o capital e o trabalho. Esta categoria pode ser melhor definida, de um modo mais específico, como uma forma de produção que combina as relações internas e externas de produção, as quais conectam a unidade produtiva familiar com circuitos mais amplos de capital. Diferentes combinações de relações internas e externas servem de base para a definição de diferentes formas de produção, representando, cada uma delas, diferentes modos de integração com o capitalismo. Estas formas de produção, no entanto, não devem ser vistas enquanto modelos pré-fabricados de explicação acerca do processo de integração da agricultura familiar ao capitalismo. Inversamente, estas formas de produção poderiam ser descritas através de diferentes processos de subordinação do trabalho ao capital.

Não obstante a importância significativa das várias contribuições teóricas que podem ser encontradas no interior da Sociologia da Agricultura, o autor que mais se aproxima das convicções analíticas aqui perseguidas é Terry Marsden. Na opinião de Marsden (1995, p.291), em razão do recuo do padrão fordista de produção (também chamado de "pós-produtivismo") na agricultura, revitalizam-se formas de produção e reprodução da força de trabalho no meio rural, sendo a pluriatividade a expressão mais eloqüente desse redirecionamento. ${ }^{36}$ Assim, o espaço rural, que durante o fordismo se limitara a cumprir suas funções produtivas agrícolas, vai ganhando novas atribuições e aparece como ambiente onde se desenvolvem múltiplas atividades produtivas.

Entre as novas funções do espaço rural, o autor destaca o papel do consumo de bens materiais e simbólicos (propriedades, festas, folclore, gastronomia, por exemplo) e serviços (ecoturismo, atividades ligadas a preservação ambiental, etc), tentando mostrar que na fase pós-fordista o espaço rural não pode mais ser associado apenas à produção agrícola e ao uso da terra para cultivos de produtos alimentares e matérias-prima. Portanto, para se compreender o rural é preciso ir além da perspectiva do agri-food system e recolocar a análise nos termos das relações de produção e consumo e da relação do espaço local com as mutações globais, a partir de uma perspectiva espacial e temporal apoiada na noção de desenvolvimento desigual. Nesse sentido, Marsden propõe que o conceito chave para explicar a nova configuração sócio-econômica e espacial do rural é a commoditization que, “...representa um amplo processo social e polí-

\footnotetext{
${ }^{36}$ O pós-produtivismo é definido por Marsden (1995, p. 294) como "uma fase que é parcialmente apoiada pela habilidade inerente dos agricultores de se integrar a agentes e setores de atividades não-agrícolas".
} 
tico pelo qual os valores mercantis são construídos e atribuídos - neste caso - a objetos rurais e agrícolas e também ao artesanato e às pessoas. Ela não representa um processo único e universal o qual transforma, por exemplo, o processo de trabalho na agricultura (tal como sugerido na literatura marxista sobre o desenvolvimento agrário). Trata-se, pelo contrário, de um fenômeno diversamente construído, em torno do qual os processos de desenvolvimento coalescem e se generalizam" (Marsden, 1995, p. 293, grifado no original). ${ }^{37}$

Com base nessas formulações, Marsden (1993) considera que a pluriatividade tende a se generalizar tanto em áreas de produção agrícola, onde o avanço tecnológico diminuiria a demanda de trabalho nas propriedades, como nas demais zonas rurais, onde o próprio Estado vêm estimulando o desenvolvimento de outras atividades econômicas, como o turismo e o artesanato. $\mathrm{O}$ autor acredita que esse processo conduzirá à revalorização do espaço rural, especialmente em razão do rápido crescimento do movimento ambientalista e dos processos de descentralização industrial, que tendem a ampliar o mercado de trabalho e, conseqüentemente, o exercício da pluriatividade pelas famílias rurais.

Nesse sentido, Marsden vê a pluriatividade como uma configuração par excellence das relações de trabalho contemporâneas, decorrente dos processos de relocalização econômica. Mesmo assim, embora Marsden insista no fato de que a pluriatividade seja uma decorrência da reconfiguração social, econômica e espacial da reestruturação capitalista, também chamada de fase pós-fordista, o autor reconhece que esses elementos "exógenos" (especialmente o mercado de trabalho de atividades não-agrícolas) não são suficientes para explicar inteiramente o fenômeno da pluriatividade. Para se compreender que tipo de impactos diferenciados essas transformações provocam nas decisões das famílias rurais, especialmente no que se refere ao recurso à pluriatividade como estratégia de reprodução social, Marsden (1990, p. 378) sugere que se analisem as relações sociais internas das propriedades e os seus processos produtivos. Nesses termos, Marsden sugere que se "abra conceitualmente" a farmhouse door a partir do estudo das relações sociais engendradas pela dinâmica do processo de trabalho.

Outro autor que se constitui em importante referência para este trabalho é Anthony Fuller. Embora não afirme explicitamente sua adesão à Sociologia da Agricultura, seu referencial analítico é notoriamente li-

\footnotetext{
${ }^{37}$ Em outro trabalho, Marsden (1989, p.314) define a mercantilização como "[...] o processo de commoditization, em linhas gerais, envolve a extensão da forma mercadoria a novas esferas de atividade ou, o que é mais usual nas economias avançadas, a superposição de novos tipos de relações mercantis".
} 
gado à "perspectiva crítica", embora integre uma corrente teórica difusa e eclética que, de modo geral, está de acordo com a interpretação da pluriatividade a partir dos mecanismos que as famílias estabelecem com o mercado (no caso o mercado de trabalho), enfatizando que a natureza da divisão interna do trabalho exerce uma influência decisiva sobre as estratégias de reprodução adotadas por essas unidades. De forma mais ou menos explícita, Fuller concorda com a idéia de que se pode explicar a pluriatividade a partir da dinâmica interna das unidades familiares e de sua relação com o ambiente social e econômico externo sendo, portanto, sua perspectiva analítica complementar à abordagem proposta por Marsden.

Em seus trabalhos mais recentes, especialmente atuando como consultor principal no âmbito do projeto sobre "Estruturas Agrárias e Pluriatividade das Famílias Agrícolas (1987-1990)", patrocinado pelo Arkleton Trust, Fuller $(1987,1990)$ tem defendido a idéia de que se deve estudar a pluriatividade a partir da dinâmica interna da família, além de perceber suas reações ao jogo das instituições e dos condicionantes do mercado no sistema local. Para Fuller a pluriatividade é um elemento de diversificação que pode se produzir no interior da família ou a partir do exterior, pois ela funciona como uma estratégia que se modifica de acordo com a dinâmica das famílias e de sua relação com a estrutura agrária existente (Brun e Fuller, 1991, p.25).

Nesse sentido, para Fuller (1990, p. 368), a pluriatividade apresenta variações muito expressivas de situações de espaço e tempo, ainda que se possa afirmar que sua característica fundamental seja a interação entre a agricultura, a unidade familiar e o mercado de trabalho. Do ponto de vista teórico e conceitual, isso implica a definição de três níveis de análise do fenômeno, que também foram utilizados no estudo realizado pelo Arkleton Trust. O primeiro toma a pluriatividade como uma expressão de determinados tipos de economias regionais ou locais. Nesse caso, trata-se da sua projeção espacial no contexto regional ou local, bem como de suas interações com a estrutura econômica e as condições socioculturais e políticas ali instauradas. Nesse caso, trata-se de saber quais os fatores regionais ou locais exercem poder de atração e estímulo ou de limitação ao desenvolvimento da pluriatividade. O segundo nível de análise refere-se à abordagem da família como o núcleo das decisões para compreender as relações entre a agricultura e a pluriatividade. As decisões de alocação dos recursos disponíveis (capital, trabalho, etc.), bem como a opção por uma determinada estratégia de investimento em atividades agrícolas ou não-agrícolas, são tomadas pelas famílias e são decisivas para a compreensão das diversas formas possíveis que assume a pluriatividade. O último nível de análise, por sua vez, refere-se à interpretação da pluriatividade como uma expressão da dinâmica das transformações socioeconômicas estruturais dos espaços rurais. Ou seja, trata- 
se do enfoque histórico e comparativo entre regiões, comunidades e até países para averiguar os fatores que podem contribuir para explicar as distintas funções da pluriatividade como, por exemplo, o tamanho e a composição das famílias e a disponibilidade de um mercado de trabalho de atividades nãoagrícolas (Brun e Fuller, 1991, p. 26 a 28).

\subsection{AGRICULTURAFAMILIAR EPLURIATIVIDADE: ELEMENTOS TEÓRICOS}

Estudar a pluriatividade como uma prática social decorrente da busca de formas alternativas para garantir a reprodução das famílias de agricultores impõe ao pesquisador explicitar o que é entendido por agricultura familiar. Isso não significa que outras formas sociais de uso da terra e do trabalho, que não as familiares, não possam ter, na prática da pluriatividade, um dos mecanismos de reprodução, ou mesmo de ampliação de fontes alternativas de renda. Mas não será essa a preocupação fundamental deste trabalho. O que aqui interessa é avaliar o significado econômico, o sentido social e a afirmação cultural da pluriatividade em famílias que residem no espaço rural e integram-se em outras atividades ocupacionais além da agricultura.

Enquanto fenômeno social e econômico presente na estrutura agrária dos países desenvolvidos e em alguns países emergentes, como no caso do Brasil, podemos definir a pluriatividade como um fenômeno através do qual membros das famílias de agricultores que habitam no meio rural optam pelo exercício de diferentes atividades, ou mais rigorosamente, optam pelo exercício de atividades não-agrícolas, mantendo a moradia no campo e uma ligação, inclusive produtiva, com a agricultura e a vida no espaço rural. Nesse sentido, ainda que se possa afirmar que a pluriatividade é decorrente de fatores que lhe são exógenos, como o mercado de trabalho não-agrícola, ela é uma prática que depende das decisões dos indivíduos ou das famílias.

Com efeito, ao situar como tema de estudo a agricultura familiar e como objeto específico a pluriatividade, delimita-se o "campo" de análise do social. Os referenciais teóricos utilizados para interpretar esse objeto se apoiam no debate sobre a natureza social e econômica da agricultura familiar a partir do pensamento social crítico. Assim, propõe-se que a discussão teórica da pluriatividade não se faça de maneira desconectada do debate mais amplo sobre a persistência da forma familiar de produção dentro do capitalismo. O que certamente introduz algumas perguntas: em que condições, por exemplo, essa persistência ou reprodução ocorre? Além disso, quais são os 
fatores aos quais se deve essa persistência ou reprodução e em que condições históricas, em que ambiente social e econômico ela encontra elementos favoráveis ou constrangimentos à sua reprodução social?

Conforme apontado no capítulo anterior, esse enfoque não se concentra apenas na análise do papel da "forma familiar de produção" no processo de acumulação de capital, pois sua preocupação central é tentar entender a sua transformação sob o capitalismo. Parte-se do pressuposto de que a forma familiar existe no interior da sociedade mais ampla e que, em determinadas situações históricas, ela certamente terá sua dinâmica e reprodução determinadas pelo regime capitalista. Mas essa não é uma "regra universal" e o modo pelo qual a forma familiar se relaciona com o capitalismo pode variar e assumir feições muito particulares. Em alguns casos históricos, essas formas sociais acabaram sucumbindo e sendo absorvidas pelo próprio capitalismo mas, em outros, como no caso de certas configurações da pluriatividade, a agricultura familiar pode desenvolver relações até relativamente estáveis e duradouras com as formas sociais e econômicas predominantes no capitalismo. Assim, as unidades familiares subsistem com uma relativa autonomia em relação ao capital e vão-se reproduzindo nessas condições. A sua transformação vai depender de sua relação com as formas distintas e heterogêneas de estruturação social, cultural e econômica do capitalismo em um certo espaço e contexto histórico.

Entre os estudiosos das unidades familiares, há uma controvérsia metodológica que, segundo Neves (1995), decorre em larga medida da "capitulação" dos pesquisadores ao raciocínio dualista, tipológico e ordenador da heterogeneidade. Nesse caso, estaria em jogo uma definição das unidades familiares que utiliza como referencial a outra forma de uma suposta polaridade, a unidade capitalista ou a empresa capitalista. Às formas familiares corresponderiam características como trabalho familiar, formas de resistência à apropriação do excedente via mercado, a propriedade de meios de produção, a busca de autonomia, etc., enquanto as formas capitalistas seriam definidas por assentarem-se no trabalho assalariado, apropriação de mais-valia, reprodução ampliada, racionalidade dirigida à obtenção de produtividade e rentabilidade, entre outros aspectos. Dessa classificação derivam qualificações empíricas, muitas vezes utilizadas para adjetivar os próprios produtores investigados, como a polarização entre produtor tecnificado ou capitalizado versus os camponeses, pobres ou tradicionais. O prejuízo desse tipo de raciocínio analítico, que, segundo a autora, deriva dos equívocos metodológicos dos pesquisadores, é que ele reduz a compreensão e a explicação das formas sociais existentes no campo à mera contraposição de dois tipos de racionalidades: uma social, ca- 
racterizada pelas unidades familiares, e a outra, econômica, consagrada à empresa capitalista.

Frente a essa controvérsia, acredita-se ser possível e adequado delinear alguns elementos para a construção de uma definição da agricultura familiar ou da forma familiar de organizar o trabalho e a produção na atividade agrícola, que podem ser úteis para compreender suas características em sociedades capitalistas. O primeiro elemento para se definir a agricultura familiar está relacionado com a forma de uso do trabalho. Unidades familiares funcionam, predominantemente, com base na utilização da força de trabalho da família e de seus membros, podendo contratar, em caráter eventual ou temporário, outros trabalhadores. No entanto, a utilização de critérios de quantificação, para determinar o limite a partir do qual uma unidade familiar que usa trabalho contratado deixa de ser considerada como tal, constitui-se em operação heurística que, isoladamente, não é suficiente para se entender e caracterizar sociologicamente qual é a natureza dessa unidade familiar, como vivem e se reproduzem seus integrantes e por que tomam determinadas decisões. ${ }^{38}$

O segundo elemento a ser considerado para entender-se a agricultura familiar e explicar sua persistência no capitalismo refere-se aos obstáculos oferecidos pela natureza, que impedem que a atividade agrícola torne-se essencialmente correspondente à atividade produtiva industrial. Embora notórios, os avanços científicos e tecnológicos ainda não conseguiram eliminar a "base natural" sob a qual assenta-se a produção de alimentos e fibras ou subverter os processos produtivos agrícolas a ponto de poder-se afirmar que agricultura e indústria já não mais se distinguem à luz de seu modo de funcionamento. De fato, malgrado argumentos em contrário, um olhar de conjunto sobre a produção agrícola é suficiente para convencer o observador atento de que esta é uma atividade ainda muito dependente de fatores naturais como o clima, os solos ou o equilíbrio dos ecossistemas. Na agricultura, o tempo de trabalho gasto para produzir uma mercadoria, sobretudo nas situações em que a produção é especializada, não corresponde ao tempo de produção necessário à sua elaboração. Além disso,é cada vez mais perceptível o apelo que a produção dita "natural" de alimentos exerce sobre os consumidores, forjando inclusive situações de mercado próprias para essas mercadorias. Portanto, as barreiras natu-

\footnotetext{
${ }^{38}$ Ao analisar-se uma situação concreta, utilizando-se como variável a forma de uso da força de trabalho, e concluir-se pela caracterização de determinadas unidades pelo seu caráter familiar ou capitalista, acaba-se, no limite, por reproduzir uma fórmula dualista de pensamento que pouco agrega à explicação sociológica. Para o aprofundamento desse debate, consultar o excelente artigo de Neves (1995).
} 
rais continuam limitando o desenvolvimento de economias de escala na agricultura, impedindo a subordinação integral dos processos produtivos ao interesse do capital e, por isso, operando com base em relações de trabalho não-assalariadas. Frente a esses condicionantes, parcela majoritária da produção agroalimentar dos países capitalistas mais desenvolvidos continua nas mãos dos agricultores familiares.

$\mathrm{O}$ terceiro elemento que auxilia a compreender analiticamente a forma familiar de trabalho pode ser extraído do legado da teoria social crítica. A insistência da tradição marxista em privilegiar o enfoque do desenvolvimento agrário como um processo macrossocial e econômico, ao invés do papel do campesinato como ator, pode aqui ser recuperada desde que sofra uma ajustamento importante, qual seja: deslocá-la da posição holística e nomológica sem desconsiderar que a compreensão dos destinos da agricultura familiar passa pelo entendimento do ambiente social e econômico em que estiver inserida. Esse ambiente compõe-se de um espaço social e econômico e de um conjunto de instituições, que tendem a fornecer estímulos e determinar limites e possibilidades e, assim, exercer uma influência exterior decisiva sobre as unidades familiares. As relações dos agricultores familiares com o ambiente social e econômico no qual estiverem inseridos pode ocorrer através do crédito, do financiamento ou outra forma de apoio institucional, via Estado ou ONGs, mas também pelo acesso a mercados de produtos (compra de insumos e venda de mercadorias, relação com agroindústrias, etc.), mercados de trabalho (como a possibilidade de obter rendas em atividades não-agrícolas), de informações e das inovações produzidas pelo progresso tecnológico. Além disso, o ambiente social e econômico também se traduz para os membros das famílias em termos das mutantes expectativas e percepções que nutrem em relação ao seu futuro e às possibilidades de desenvolvimento do local em que vivem.

Mas o elemento central, que patrocina a relativa estabilidade e exerce um papel regulador entre os diferentes elementos apresentados, é a própria natureza familiar dessas unidades. Esta natureza familiar está assentada nas relações de parentesco e de herança existentes entre os membros dessas unidades. É no interior da própria família e do grupo doméstico, através das relações sociais que se estabelecem entre seus membros participantes, que se localizam as principais razões que explicam a persistência e a reprodução de um certo conjunto de unidades e a desagregação e o desaparecimento de outras. É em razão das decisões tomadas pela família e pelo grupo doméstico, frente às condições materiais e ao ambiente social e econômico no qual estiver inserida, que ocorrerá ou não sua reprodução social, econômica, cultural e moral. 
Mesmo que, em certos casos, as unidades familiares estejam submetidas a determinados condicionantes externos como, por exemplo, o monopólio de preços ou os diferentes tipos de mercados (de trabalho, de crédito, de produtos e insumos), o fato de estruturarem-se com base na utilização da força de trabalho dos membros da unidade familiar permitirá que determinadas decisões tornem-se possíveis; o que, em muitos casos, um agricultor amplamente inserido na dinâmica capitalista, que conta com a contratação de assalariados, não poderia concretizar ou estaria sujeito a fortes restrições. Isso não implica concordar com a afirmação de que essa especificidade do caráter familiar seja suficiente para explicar por que essas unidades conseguem reproduzir-se ou resistir mesmo em condições adversas.

A reprodução social, econômica, cultural e simbólica das formas familiares dependerá de um intrincado e complexo jogo através do qual as unidades familiares relacionam-se com o ambiente e o espaço no qual estão inseridas. Nele os indivíduos e a família devem levar em conta o bem-estar e o progresso de sua unidade de trabalho e moradia e as possibilidades materiais de alcançar determinados objetivos. Desse modo, a reprodução não é apenas o resultado de um ato da vontade individual ou do coletivo familiar e tampouco uma decorrência das pressões econômicas externas do sistema social. A reprodução é, acima de tudo, o resultado do processo de intermediação entre os indivíduos-membros com sua família e de ambos interagindo com o ambiente social em que estão imersos. Nesse processo, cabe à família e a seus membros um papel ativo, pois suas decisões, estratégias e ações podem trazer resultados benéficos ou desfavoráveis à continuidade e à reprodução.

Essa perspectiva permite romper com o usual reducionismo classificatório dos estudos sobre agricultura familiar, pois nem a categoria trabalho estritamente familiar nem a contratação ou não de assalariados, tampouco as relações com o mercado, servem, isoladamente, como critérios que se bastam para definir a natureza de uma determinada forma social. Nesse sentido, para se entender o significado da pluriatividade em situações nas quais predomina a agricultura familiar a partir das ferramentas conceituais disponibilizadas pela sociologia crítica, é preciso admitir que determinadas formas sociais se transformam (no sentido de que se superam), se metamorfoseiam e se reproduzem fora do escopo rígido das leis de valorização do capital. Trata-se de aceitar a hipótese de que determinadas formas sociais relacionam-se com o modo de produção dominante sem que as relações que se estabelecem entre ambos sejam, a priori, de caráter capitalista. A contratação eventual ou regular de assalariados pelas unidades familiares ou sua entrada em circuitos mercantis, seja pela venda da força de trabalho (via atividades não-agrícolas) ou pela venda de 
produtos agrícolas, não autoriza sua compulsória categorização como capitalistas.

\subsection{ESBOÇO DE UMAPROPOSTATEÓRICA PARAOESTUDODAPLURIATIVIDADE}

De certo modo, o amplo apoio recolhido por esta perspectiva a partir das indicações de autores ligados à Sociologia da Agricultura permite dizer que há muitas concordâncias com esse aporte no que se refere à identificação do cenário social e econômico em que transcorrem as transformações do capitalismo contemporâneo. Concorda-se, por exemplo, com o diagnóstico geral acerca da crise do fordismo e da validade das suas explicações sobre as novas formas de regulação social e econômica da estrutura agrária, fortemente marcadas pela consolidação do sistema agroalimentar internacional e pela mercantilização crescente tanto das relações de produção como daquelas dimensões que Marsden enquadra na esfera do "consumo não-produtivo", como a paisagem rural, o clima, o ambiente natural, etc.

No entanto, em relação às avaliações sobre a pluriatividade e sobre a emergência de novas formas de regulação do trabalho no meio rural, a adesão da perspectiva analítica aqui proposta às idéias defendidas pelos autores da Sociologia da Agricultura é relativa e parcial. Embora se aceite que as transformações do mercado de trabalho sejam conseqüências de um padrão pós-fordista em gestação, é difícil aceitar que a pluriatividade seja um fenômeno decorrente apenas de processos sociais e econômicos externos às unidades familiares, sem implicar qualquer tipo de (re)ação dos sujeitos afetados. Seria um equívoco imaginar que os agricultores familiares sejam meros coadjuvantes ou simples bearers of structures (suportes das estruturas) e que não contribuam, em alguma medida, para afirmação e significação da pluriatividade.

As avaliações dos autores da Sociologia da Agricultura parecem satisfatórias em relação aos aspectos macrossociológicos pelos quais se explica o recurso dos agricultores às atividades não-agrícolas. Contudo, elas têm pouco a dizer sobre as motivações dos indivíduos, de como tomam suas decisões de dispêndio ou investimento ou mesmo sobre os projetos que orientam suas estratégias de busca de alternativas materiais à sua reprodução social. Ou seja, para entender a complexidade das relações sociais que são engendradas nesse processo, é preciso estudar a pluriatividade a partir do modo como é exercida pelos próprios agricultores familiares.

Como mostra Fuller, se, por um lado, é correto imaginar que a pluriatividade é uma reação dos agricultores a um conjunto de situações objetivas, que 
a eles se apresentam como exterioridades, por outro, não é menos verdade que a percepção que cada família ou cada indivíduo faz dessas realidades se deve a aspectos subjetivos, individuais ou coletivos, dos quais depende, por exemplo, a adesão ou não a determinadas estratégias de trabalho. Segundo Fuller (1990,p.367),

A lógica a partir da qual as unidades domésticas adotam diferentes padrões de atividade vai depender das condições existentes na agricultura, das oportunidades de trabalho fora da unidade produtiva familiar, da estrutura da família e suas mudanças ao longo do tempo. A estratégia (consciente ou inconsciente) adotada pela unidade doméstica vai depender da percepção que as famílias têm destas realidades, a qual depende, por sua vez, da aspiração e valores de seus membros e do processo através do qual as decisões são tomadas na unidade doméstica. A pluriatividade é vista como uma forma de acomodar a mudança, de se adaptar à realidade da agricultura (por exemplo, minimizando risco), maximizando oportunidades, construindo uma família e permanecendo na terra.

Em razão disso, considera-se necessário descer ao ambiente intrafamiliar para conhecer melhor os mecanismos pelos quais uma família se torna pluriativa e de que modo ela exerce essa pluriatividade. Somente com base nessas informações é que poder-se-á discutir a questão teórica central que motiva essa investigação, que se refere à possibilidade da pluriatividade constituir-se em uma nova estratégia de reprodução social das unidades familiares. Nesse sentido, a análise da pluriatividade a partir das relações intra-familiares segue a orientação metodológica estabelecida por Llambi (1990,p.222):

Identificar las relaciones internas de tales unidades, es decir, las relaciones entre sus miembros (parientes, amigos,o socios), así como las normas para distribuir el producto social entre sus miembros, constituyen materia para las investigaciones empíricas. Como también es objecto de la investigacion empírica el análisis de las relaciones internas entre la unidad y el resto de los agentes sociales (por exemplo, al interior de circuitos de acumulación de capital), y entre los miembros de la unidad y otros agentes sociales. Precisamente, el identificar en la investigación empírica las relaciones internas y externas de la unidad constituye una de las principales tareas que pueden proveer contenido histórico (es decir, social) al análisis de la reproducción social a nivel micro. 
Desse modo, para enfocar a natureza e a diversidade da forma familiar de trabalho, nas regiões e espaços rurais onde a pluriatividade é um fenômeno corrente, justifica-se e torna-se necessário agregar alguns elementos teóricos. Nesse sentido, pretende-se resgatar aspectos do enfoque analítico que foi legado por Chayanov para explicar o processo de tomada de decisão dos agricultores em relação ao contexto no qual se insere sua propriedade e a disposição dos fatores de produção. O que se tentará evidenciar é a operacionalidade de duas proposições fundamentais de seu modelo de análise que parecem úteis à descrição do caráter familiar do trabalho pluriativo, bem como dos aspectos intra-familiares que permitem a reprodução social da unidade produtiva.

Considera-se que a perspectiva chayanoviana permite estabelecer referenciais microssociológicos importantes para compreender a dinâmica intra-familiar das unidades agrícolas. Entretanto, esse modelo precisa ser submetido a algumas considerações críticas para tornar-se operacional no estudo da pluriatividade da família rural. Concorda-se com a caracterização da dinâmica interna da propriedade camponesa, formulada por Chayanov, na qual o núcleo familiar apresenta relativa autonomia no processo de tomada de decisões entre as opções de investir, gastar ou poupar (de fato uma autonomia na definição do balanço entre trabalho e consumo), e o trabalho assalariado é ausente ou tem pouca importância. Sustenta-se, no entanto, que para explicar as recentes estratégias de trabalho pluriativas, que ocorrem em regiões do Sul do Brasil, é necessário reconsiderar o arsenal teórico chayanoviano em dois aspectos. Primeiro, no que se refere à família como unidade indivisível entre trabalho e produção e, segundo, sobre a relação da diferenciação demográfica interna da unidade econômica familiar com o crescimento da produtividade do trabalho.

Em relação ao primeiro aspecto, a pluriatividade cria uma situação na qual o postulado chayanoviano, de que o núcleo familiar é uma soma indivisível entre trabalho e produção, parece cindir-se. Isso ocorre em situações em que parcela significativa dos agricultores obtém um volume crescente de rendas que compõem o orçamento doméstico oriundas de atividades nãoagrícolas. Nessas circunstâncias ocorre a separação entre os trabalhos agrícolas, praticados dentro da propriedade, e os trabalhos executados fora da propriedade. Em muitos casos, essa cisão ocorre a partir do momento em que os filhos passam a trabalhar fora da propriedade. Entretanto, essa autonomia pode tanto reforçar os laços domésticos, quando as rendas individuais são integradas a um só orçamento familiar (tal como apontou Seyferth, 1987) como pode levar à fragmentação da renda total familiar (individualização), que ocorre quando os membros da família que trabalham fora da propriedade não repassam seus rendimentos (Gasson, 1984). 
A segunda reconsideração, relacionada à anterior, refere-se à total inversão do padrão chayanoviano da relação entre os momentos do ciclo familiar demográfico e a produtividade das unidades de produção. Em razão da possibilidade de parte dos membros da família poder se empregar fora da propriedade, cria-se uma situação na qual os anos potencialmente mais produtivos da força de trabalho familiar não coincidem com os momentos de maior exploração da terra e desempenho produtivo da unidade. Há, inclusive, estudos que demonstram que, nas situações em que são os homens que trabalham fora, ocorre um aumento significativo da jornada e do ritmo de trabalho feminino e dos membros adultos da terceira idade, crianças e adolescentes (Pfeffer, 1989). Nesse caso, ao contrário de que previa Chayanov, o chefe da família e os outros membros em idade plena de trabalhar passam a se ocupar com trabalhos fora da propriedade durante os anos mais produtivos de suas vidas (entre 18 e 50 anos, aproximadamente), invertendo a relação positiva que esse postulado estabelecera entre o desenvolvimento demográfico e o crescimento da produtividade agrícola.

Essas reconsiderações permitem evidenciar alguns aspectos intra-familiares das unidades de produção, que mudam de natureza numa situação de pluriatividade. A intensidade de cada um varia segundo o ambiente social e econômico no qual está inserido como, por exemplo, a disposição de tecnologias, as condições de mercado e o ciclo demográfico familiar. Mais do que evidenciar aspectos peculiares, difíceis de serem aferidos empiricamente e muito raramente enfocados analiticamente, essas reconsiderações fornecem elementos a partir dos quais pode-se fazer inferências teóricas acerca do caráter da reprodução social. Como se nota, essas reconsiderações são de fato necessárias e podem servir como recursos metodológicos, para abordar sociologicamente o fenômeno da pluriatividade.É por tais razões que se acredita somente ser possível avançar a teoria social contemporânea com base numa fértil interlocução entre abordagens teóricas distintas.

\subsection{AFAMÍLIAPLURIATIVA: EMBUSCADE UMAUNIDADE DEANÁLISE}

A partir dos elementos teóricos delineados torna-se necessário fixar a unidade de observação que se considera pertinente ao estudo da pluriatividade e da agricultura familiar. Nesse sentido, a abordagem empreendida parte das famílias rurais como unidades nas quais a presença da pluriatividade deve ser entendida como um ponto de partida para reflexão sobre o próprio funcionamento e as características da agricultura familiar no final do século XX. Segundo Lacombe (1984), o fato das famílias rurais terem se transformado largamente em 
unidades nas quais coexistem diversos tipos de ocupações e atividades entre seus membros torna-os muito semelhantes às demais famílias. Nesse sentido, a análise clássica das famílias agrícolas, que consistia na sua intepretação segundo o modelo de uma propriedade $=$ uma família $=$ uma atividade $=$ uma renda , não pode mais servir de referencial para aqueles que querem compreender sua forma de organização ou sua identidade (Lacombe, 1984, p. 50, consulte-se também Delord e Lacombe, 1990).$^{39}$ Em sintonia com tais argumentos, Brun (1989) acredita que a identidade entre família e unidade de produção vem sendo crescentemente questionada devido à distensão dos laços familiares e da própria unidade familiar nas sociedades contemporâneas (perceptível no espaço rural pela queda expressiva da endogamia, pela dificuldade de inserção dos filhos nas atividades agrícolas da propriedade e, também, pela ampliação das atividades não-agrícolas assumidas pelos membros das famílias de agricultores, principalmente em função da queda generalizada das rendas agrícolas).

Em outro trabalho coletivo, esses autores questionam se o enfraquecimento ou a perda da centralidade das atividades agrícolas (impactadas pela pluriatividade) nas unidades familiares estaria provocando a perda do "caráter familiar" dessas propriedades (Blan et al., 1990). Ou seja, estaria o desenvolvimento da pluriatividade minando o caráter familiar dessas unidades? E quais categorias sociais substituirão a agricultura familiar se a pluriatividade se generalizar? A questão que submetem à análise considera que o aumento da pluriatividade das famílias rurais requer uma reflexão sobre a relação das atividades produtivas desempenhadas nas propriedades com o caráter familiar do grupo social que vive sobre ela. Como acentuam Blan, Brun, Delord e Lacombe (1990, p. 320):

A grande novidade reside na emergência, entre as gerações de jovens, de casais onde as esposas são assalariadas fora da agricultura e o marido trabalha sozinho em uma propriedade modernizada de razoável tamanho. Estas exploitations individuelles modernas não diferem das exploitations familiales somente pela composição do coletivo de trabalho, mas também pelo modo de utilização da força de trabalho familiar. Nas exploitations familiales clássicas a força de trabalho era mobilizada a todo momento. Nas exploitations individuelles modernas, a esposa tende a assumir um modo de vida assalariado, caracterizado pela clara distinção entre o tempo de trabalho e as outras atividades de não-trabalho [...] Assim a exploitation familiale tende a regredir não somente porque ela perde sua importância em termos puramente quantitativos, mas sobretudo em razão da dissociação cada vez mais clara entre o grupo doméstico-família e a unidade de produção, que se traduz no crescimento pujante das exploitations individuelles modernas.

\footnotetext{
${ }^{39}$ Para uma reflexão sobre a família agrícola e os diferentes papéis que desempenham homens e mulheres, consultar o excelente livro de Barthez (1982).
} 
Entre os autores que desenvolveram essa hipótese, da decomposição das relações familiares em situações de pluriatividade, encontra-se a contribuição de Barthez $(1982,1987)$. Ela argumenta que a pluriatividade representa uma ruptura com a monoatividade e o modelo de família agrícola, pois a atividade agrícola já não caracteriza mais a unidade de referência. A pluriatividade estaria alterando o conteúdo da unidade familiar, pois passa de uma situação na qual a propriedade era, ao mesmo tempo, lugar de residência e de produção para outra na qual ela é somente o local de moradia, uma vez que o trabalho e a produção dissociam-se geograficamente. Na opinião de Barthez (1987,p.172), "[...] a pluriatividade destrói o postulado da unidade familiar que se incluía na definição da família agrícola. Na família pluriativa cada um tende a limitar-se a uma única atividade, com suas peculiaridades específicas, que não permitem confusão. A atividade se transforma em atributo pessoal”.

Ainda segundo Barthez, a ruptura operada pela pluriatividade se dá pela destruição da "lógica da família tradicional”, baseada na fusão da unidade familiar (grupo doméstico) com a unidade profissional (atividade econômica). Portanto, a pluriatividade levaria à ruptura do "universo profissional comum a todos os membros da família agrícola", porque em uma família pluriativa cada membro passa a ter um trabalho diferente e, mesmo assim, pertence à mesma família. ${ }^{40}$ Nesse sentido, para se compreender as famílias pluriativas, Barthez (1987,p.177) sugere que se estude a mobilidade individual dos membros que pertencem ao grupo de co-habitantes, que formam essas unidades familiares modernas:

O ponto de partida já não pode ser a família como unidade em si, mas preferencialmente os indivíduos que nela co-habitam, tentando-se compreender como, a partir de sua independência pessoal, conseguem integrar-se em um projeto comum que os mantêm em uma vida em grupo [...] O grupo de co-habitantes que resulta deste duplo movimento não pode identificar-se como uma comunidade em si, fundada em regras específicas, mas, ao contrário, aparece como desenlace de trajetórias individuais e variadas que, em um dado momento, convergem em torno de um interesse comum, formando o grupo familiar.

\footnotetext{
${ }^{41}$ Segundo Barthez (1987, p. 166), essa situação é decorrente do processo de modernização e inserção da agricultura na divisão social do trabalho vigente em sociedades capitalistas. Nessa situação, observa-se a tendência à "profissionalização" das propriedades apenas pelo viés da produção e das atividades realizadas (o processo produtivo), esquecendo-se do grupo familiar. Em função da modernização tecnológica crescente a agricultura tende a se tornar um atividade individual e a propriedade, uma empresa "com responsabilidade pessoal". No entanto, quando se vai além desse viés da produção, agregando-se a unidade doméstica, a propriedade adquire a característica de "empresa familiar", reconhecendo-se que nela trabalham vários indivíduos, não necessariamente na mesma atividade.
} 
Ao lado dessa posição, que enfatiza a decomposição da família devido à crescente diversificação da inserção profissional de seus membros, encontram-se autores que sustentam que não há uma relação direta entre a organização do trabalho nas propriedades rurais e o caráter familiar da unidade como um todo. Para Marini e Pierroni (1987), por exemplo "[...] a família deve ser mantida como unidade de análise, porque ela se constituiu numa instituição social e econômica, um ator coletivo cujos aspectos são operativos para a investigação social" ${ }^{41}$ Essa definição materializa-se a partir das relações da unidade familiar agrícola com o sistema social, entendendo-o como "uma estrutura composta de múltiplas formações sociais e econômicas, que se diferenciam dentro de zonas territoriais" (p.205). Desse modo, os autores observam que, embora se deva reconhecer a importância e a autonomia das estratégias individuais no interior da família, é preciso considerar que essas estão " [...] condicionadas e mediadas pela estratégia familiar de distribuição de seus recursos de trabalho como um todo" (p.206). Ou seja, é a família em seu conjunto que define a divisão social e sexual do trabalho bem como legitima as relações internas de hierarquia e poder. ${ }^{42}$

A verificação de que a pluriatividade altera o processo de organização e alocação do trabalho no interior do grupo doméstico também provoca a alteração dos enfoques e os conceitos utilizados pelos autores. Um exemplo concreto dessa mudança de enfoque analítico da família, em situações nas quais é corrente o recurso à pluriatividade e às atividades não-agrícolas, encontrase no trabalho de Carneiro (1998). Segundo a autora, a pluriatividade, tal como já havia sido demonstrado pelos historiadores franceses, esconde uma heterogeneidade de fenômenos que podem assumir diferentes significados em contextos, épocas e lugares distintos, o que compromete sua validade heurística e conceitual. Na sua opinião,

A falta de especificidade e de valor heurístico da noção de pluriatividade nos orienta para a construção de um objeto de estudo centrado não mais sobre o conjunto de ações individuais mas sobre as condições de reprodução social no campo. Assim, se considerarmos a pluriatividade como uma resposta dos agricultores às situações e acontecimentos determinados, no contexto da unidade de produção familiar, nós devemos compreendê-la como

\footnotetext{
${ }^{41}$ Segundo esses autores, a família como "unidade ativa" apresenta três características básicas: a) ligação íntima entre a esfera produtiva e reprodutiva; b) relacionamento interno entre os membros definido pelo sexo, capacidade de trabalho, etc; c) a capacidade de cada membro depende da sua posição social no ciclo de vida da família (1987, p. 241).

${ }^{42}$ Blanc e colaboradores (1990, p. 318) também afirmam que está em andamento um processo de reorganização das unidades familiares no qual, apesar das famílias estarem se tornando cada vez menos agrícolas, a agricultura e o espaço rural vêm-se tornando cada vez mais familiares.
} 
um dos mecanismos possíveis para satisfazer as necessidades de reprodução da unidade doméstica. Consideramos assim que as diversas atividades complementares à agricultura poderão ter sentidos opostos e mesmo contraditórios, segundo o contexto histórico-social, os tipos de atividade e segundo a pessoa que os exerce. Os pesos da significação que estas atividades poderão ter para a reprodução da exploração familiar serão diferentes se elas são praticadas pelos filhos, pela esposa ou pelo chefe da unidade produtiva. É necessário portanto prever um espaço, em nossas análises, para apreender os conflitos entre os interesses individuais e os conflitos dentro da família rural. (p.159, grifo nosso).

Esse debate em torno da família como unidade de análise pertinente ao estudo da pluriatividade requer um esclarecimento acerca do enfoque deste livro. Como se sabe, a tradição dos estudos sobre a família constitui-se, desde longa data, em seara de domínio privilegiado da Antropologia e da Etnologia, especialmente quando se trata de temas como parentesco e herança. No Brasil, segundo Almeida, os estudos sobre família rural podem ser classificadas em dois enfoques analíticos, que lidam predominantemente com as questões econômicas ou extra-econômicas. Os trabalhos que se ocupam do primeiro enfoque "[...] estão preocupados com a natureza da família enquanto esqueleto externo do modo de produção camponês" e, os outros, focalizam a reprodução da unidade familiar no ciclo geracional, analisando como elas se perpetuam (Almeida, 1986, p. 67). ${ }^{43}$ Segundo o mesmo autor, esses estudos não definem claramente o significado de expressões como economia familiar, produção familiar ou família como unidade econômica apesar de, "[...] na prática, as pesquisas de produção agrícola familiar tomarem como foco uma unidade doméstica: uma casa, um lote de terra, um conjunto de pessoas. Essas pessoas são descritas então como uma família" (p.68).

Em razão da ampla diversidade de definições a que se presta a família, Almeida sugere uma definição operacional para fins analíticos, na qual a família é separada do grupo doméstico. Por família entende-se um determinado conjunto de parentes, tipicamente formado por uma família nuclear, sendo possível haver outros tipos; e, por grupo doméstico (unidade residencial e de consumo e, às vezes de trabalho), entende-se um grupo de pessoas que compartilha o espaço de uma casa e que trabalha conjuntamente. ${ }^{44}$ Assim o autor

\footnotetext{
${ }^{43}$ No primeiro grupo, segundo o autor, encontram-se autores como Garcia $(1983,1989)$, Heredia (1979) e Tavares dos Santos (1978) e, no segundo grupo, estão trabalhos como os de Moura (1978), Seyferth (1985a, 1985b), Woortmann (1995).

${ }^{44}$ Essa definição parece ser suficientemente genérica para abarcar uma diversidade de situações que, segundo Bourdieu (1993), está em constante transformação e reconstrução.
} 
acredita estar na presença de uma definição suficientemente flexível, que explica realidades diversas e situações sociais e culturais distintas, nas quais a combinação de elementos entre a família e o grupo doméstico pode variar. Além disso, Almeida relaciona duas noções centrais que são utilizadas pelos estudiosos brasileiros - a racionalidade familiar (basicamente inspirada em Chayanov) e o parentesco -, que foram utilizados por autores para explicar os mecanismos de funcionamento e reprodução das famílias rurais.

Em estudos mais recentes, como os de Woortmann (1995) e Carneiro (1998), percebe-se que a separação entre família e grupo doméstico, sugerida por Almeida, é retomada. No trabalho de Woortmann, que se propõe a compreender a reprodução camponesa, de geração em geração, através das relações de parentesco, encontra-se, inclusive, uma nítida separação entre as teorias que operaram com referenciais que consideram o parentesco como elemento da reprodução camponesa e as demais teorias, que desconsideram esses aspectos. Segundo a autora, pensadores importantes da Sociologia Rural, como Chayanov, Galeski e Mendras, apesar de afirmarem tratar da família como unidade de análise, na verdade teriam tratado de grupos domésticos de produtores e consumidores (o que a autora chamou de work-team), desconsiderando a "[...] família como um grupo hierarquicamente organizado em torno de valores culturais e de uma moralidade" (Woortmann, 1995, p. 30).

Embora sem operar claramente no escopo dessa separação entre família e grupo doméstico, a abordagem de Carneiro se aproxima mais dos objetivos aqui propostos, talvez por ter investigado famílias rurais de uma região dos Alpes franceses onde a pluriatividade constitui-se em uma marca histórica. Sua proposta é realizar "uma análise microssociológica da família que permitiria esclarecer a multiplicidade de papéis exercidos por seus membros e as tensões resultantes de seus objetivos opostos" (Carneiro, 1998, p. 9). Para a autora, os elementos que articulam e estruturam o sistema das relações individuais na família e nas sociedades são o parentesco e o trabalho.

No caso de Carneiro, a família constituiu-se, de fato, na unidade de observação de um processo mais amplo de transformação da sociedade e da agricultura de montanha da França. Para Carneiro, contudo, “[...] a família não deve ser entendida tão-somente como um grupo estruturado segundo as condições históricas e culturais que o cercam. É necessário considerar também o conjunto de valores que orientam e dão sentido às práticas sociais no interior da família, já que ela agrega indivíduos de uma rede de relações que inclui, como toda relação social, uma parte ideal, de pensamento ou, se quisermos, de representação" (p. 66). Ao contrário de Woortmann, Carneiro não distingue a família e o grupo doméstico, ainda que considere que cada um desses espaços funciona com uma certa autonomia. Assim, "[...] a família é espaço de produção e reprodução de valores cujos significados ultrapasssam a lógica do parentesco e da racionalidade econômica" (p.9). 
Para operacionalizar essa definição analítica da família, Carneiro propõe que os pesquisadores elaborem uma distinção entre o domínio do trabalho (ou da produção) e do parentesco, o que lhes permitiria fugir do reducionismo das análises que atribuem uma funcionalidade econômica a um desses sistemas de relações. Para não cair nessa armadilha, sugere "[...] elaborar a distinção entre estes dois domínios e buscar, simultaneamente, a lógica que os une no interior do grupo doméstico, sem contudo diluir as diferenças entre o que é da produção e o que é da família (p. 9). ${ }^{45}$ Nesse sentido, sua proposta está de acordo com as sugestões de Neves (1997; 1995), que sugere a separação heurística e conceitual entre unidade familiar e unidade de produção, como forma de viabilizar a compreensão das formas familiares de organização do trabalho sem recorrer à sua "contraposição", isto é, às unidades capitalistas de produção ou à empresa capitalista. ${ }^{46}$ Segundo Neves, essa postura metodológica permite o estudo da dinâmica da organização familiar sem necessariamente determinar ex ante os projetos familiares ou os resultados das pressões do ambiente externo. A distinção entre a unidade familiar e unidade de produção permite que venha à tona a coexistência de múltiplos projetos diferenciados e arranjos entre os membros da família, pois “[ ...] as unidades de produção são arranjos contingenciais. Não são essências. São formas de conexão, de disjunção e de conjunção. São sistemas de procedimentos e de estratégias e não uma estrutura dada à qual aos indivíduos só cabe a própria modelação" (Neves, 1995, p. 34).

A unidade de análise aqui adotada e que deverá se constitur em locus privilegiado da observação sociológica é a família rural, entendida como um grupo social que compartilha um mesmo espaço (não necessariamente uma habitação comum) e possui em comum a propriedade de um pedaço de terra. Esse coletivo está ligado por laços de parentesco e consangüinidade (filiação) entre si, podendo a ele pertencer, eventualmente, outros membros não-consangüíneos (adoção). É no âmbito da família que se discute e se organiza a inserção produtiva, laboral e moral dos seus diferentes membros integrantes e é em função deste referencial que se estabelecem as estratégias individuais e coletivas. Embora seu objetivo seja a reprodução material, cultu-

\footnotetext{
${ }^{45}$ Essa posição é reforçada em um trabalho mais recente no qual a autora propõe, claramente, que "eleger como unidade de observação a unidade familiar, ou o grupo doméstico, revela-se como procedimento fundamental para a compreensão das transformações recentes do campo brasileiro, onde o aumento das atividades não-agrícolas, articuladas ou não à agricultura, exige maior grau de complexidade da análise" (Carneiro , 1999, p. 17).

${ }^{46} \mathrm{Na}$ verdade, a separação analítica da família em unidade de produção e unidade doméstica refere-se a um movimento metodológico que passou a figurar em várias pesquisas a partir do momento que a noção de pluriatividade passou a ocupar o lugar da definição de part-time farming, tal como ressaltado neste capítulo. Para mais informações, consultar Fuller $(1984,1990)$ e Bell e Mackinnon (1988).
} 
ral e moral do grupo, não há caminho pré-determinado ou estratégias definidas ex ante, mesmo que nos casos empíricos estudados a inserção no mercado de trabalho de atividades não-agrícolas seja uma alternativa freqüentemente trilhada pelos membros da família, o que poderá não se repetir se essa mesma definição for utilizada para investigar outros contextos sociais e econômicos.

A separação analítica das unidades familiares em unidades de produção e grupos domésticos é particularmente operacional ao estudo de situações nas quais as famílias ou os indivíduos recorrem às atividades não-agrícolas e à pluriatividade como estratégias ou mecanismos para viabilizar seus interesses pessoais ou coletivos, em geral traduzidos na busca de rendas mais altas ou trabalhos menos penosos que a atividade agrícola. Estudo pioneiro nesse sentido foi realizado por Neves ao analisar as relações entre os agricultores e os mercados de trabalho e de bens e serviços a partir do estudo de dois casos concretos (a região canavieira de Campos e de pecuária leiteira do Vale do Itabapoana, ambos no Rio de Janeiro). Segundo a autora, "[...] a dissociação entre a unidade familiar e a unidade de produção permite enfatizar a importância que o projeto familiar assume nessas estratégias de integração social, sobretudo ao entendimento da pluriatividade do chefe ou de alguns membros da família" (Neves, 1997, p. 10). No caso da região de Campos, a pluriatividade das famílias de agricultores está relacionada ao trabalho que os seus membros exercem durante a colheita da cana-de-açúcar ou a prestação de serviços durante a safra (como motoristas ou tratoristas, por exemplo) e, no segundo caso, mediante a combinação do trabalho nas fazendas de pecuária e o cultivo de pequenas áreas de terra com produtos para sua subsistência. Nesses dois casos, segundo a autora, pode-se afirmar que a pluriatividade se revela como uma estratégia das famílias frente à escassez de terra (e a impossibilidade de expansão da fronteira agrícola) e como uma resposta às contradições criadas pelo sistema de herança igualitário, que acabou inviabilizando muitas propriedades devido à redução excessiva de seu tamanho.

Conforme também haviam sugerido Fuller(1984) e Barthez (1987), a separação da unidade familiar em unidade de produção e grupo doméstico funciona como recurso metodológico que permite ir além das necessárias, mas insuficientes, medidas da quantidade de tempo de trabalho e do valor das rendas obtidas fora da propriedade como critérios definidores de uma unidade pluriativa.Assim, será possível também evidenciar as diferentes formas de alocação do trabalho no interior da propriedade que, provavelmente, variam entre unidades exclusivamente agrícolas e aquelas que combinam a agricultura com outros tipos de atividades. Isto permitirá compreender as variações da pluriatividade em situações nas quais as propriedades, seus sistemas produtivos e o contexto social e econômico são muito semelhantes, como acontece nos dois casos investigados neste livro.Além disso, essa separação entre unidade de produção e grupo doméstico também per- 
mitirá ativar a variável da composição demográfica da família como elemento importante à compreensão da pluriatividade, bem como os efeitos diferenciados que decorrem da inserção do homem ou da mulher em atividades não-agrícolas.

Além dessa "manobra heurística", que pretende dar um enfoque multidimensional à unidade de análise sugerida - a família rural - considera-se necessário tecer um último comentário sobre a utilização do conceito de estratégia (que muitas vezes aparece adjetivado como estratégia de reprodução), que não é apenas o elo de ligação entre as unidades familiares investigadas e o ambiente externo, mas também a ligação que parece superar a dicotomia sociológica em torno do problema da relação estrutura-agente ou processos micro versus macro.

Segundo Crow (1989), o conceito de estratégia é de uso corrente entre vários enfoques sociológicos e a nenhum deles cabe reclamá-lo como propriedade de uso exclusivo. ${ }^{47}$ A utilização do conceito de estratégia, afirma ele, passou a generalizar-se entre os cientistas sociais nas décadas recentes para fazer frente à incapacidade crescente de explicação das perspectivas estruturalistas e funcionalistas. Apesar de sua ubiqüidade, o conceito de estratégia é largamente utilizado pelos estudiosos do individualismo metodológico (Goffmann) e aqueles que privilegiam a ação coletiva, a partir do referencial da teoria da escolha racional, especialmente a chamada "teoria dos jogos" (Elster, Olson e outros).

A utilização do conceito de estratégia, ainda segundo Crow, coloca em evidência conceitos centrais da Sociologia, tais como a escolha, o poder, a interação social, a reprodução, e suscita uma discussão sobre o tipo de ação, racional ou não-racional, que é empreendida por aqueles que colocam em prática as estratégias. Nesse sentido, a sugestão é que sua utilização leve em consideração o enfoque teórico ao qual se vincula a perspectiva analítica desenvolvida e que sejam adotados níveis ou esferas objetivas nas quais se pode interpretar a ação individual ou coletiva a partir do conceito de estratégia. $\mathrm{O}$ primeiro nível é o da sociedade, no qual o conceito pode ser útil para descrever as ações do Estado ou as escolhas das elites do poder frente a determinado tipo de iniciativa (por exemplo, as chamadas "estratégias de desenvolvimento" de um determinado governo ou instituição). O segundo nível é o das estratégias de interação social, que envolvem as ações de grupos e classes, cujas escolhas políticas e formas de organização podem envolver diferentes atitudes. Nesse nível, trata-se das estratégias dos empresários, dos trabalhadores e das demais categorias sociais como os agricultores, por exemplo. $\mathrm{Na}$ terceira esfera encontram-se as estratégias das famílias e dos grupos domés-

\footnotetext{
${ }^{47}$ Além do excelente artigo de Crow, ver também os comentários de Morgan (1989) e Watson (1990) e o trabalho de Davidson (1991), que insiste na idéia de que as unidades familiares e as estratégias representam uma alternativa à compreensão da dicotomia estrutura versus agentes.
} 
ticos, que também variam de acordo com interesses individuais e coletivos resultantes de suas convicções. ${ }^{48}$ Esse é o nível privilegiado da percepção de como se dão as estratégias de alocação de trabalho e recursos no interior de um pequeno grupo social, que é perpassado por laços de parentesco e consangüinidade e orientado por valores morais e culturais que se materializam de diversas formas e sentidos. Finalmente, o nível das estratégias dos indivíduos, que varia não apenas de acordo com as decisões e desejos pessoais, obviamente decorrentes das relações mais amplas que forem constituídas, mas, sobretudo, deve ser compreendido a partir do referencial teórico escolhido, sob pena do investigador cair na descrição de uma miríade de atitudes e ações sem sentido sociológico algum.

Nesse sentido, a utilização do conceito de estratégia levará em consideração os marcos teóricos e conceituais sobre as unidades familiares e sua relação com o contexto socioeconômico específico, esboçados neste capítulo. Do ponto de vista substantivo, as estratégias são interpretadas como o resultado das escolhas, opções e decisões dos indivíduos em relação à família e da família em relação aos indivíduos (Marini e Pieroni, 1987).É preciso ponderar, contudo, que essas estratégias ocorrem nos limites de determinados condicionantes sociais, culturais, econômicos e até mesmo espaciais, que exercem pressões sobre as unidades familiares. Portanto, a tomada de decisões e as opções, sejam quais forem, de indivíduos e famílias, possuem um referencial que na prática se materializa através das relações sociais, econômicas e culturais em que vivem. Assim, embora tratem-se de estratégias conscientes e racionais, essa consciência é mediatizada por uma racionalidade informada pela realidade que tanto é a expressão das relações materiais presentes como daquelas herdadas de seu passado e transmitidas culturalmente. Desse modo, as estratégias não são causais ou teleológicas, mas resultado da ação humana frente às contingências e situações objetivas. Não obstante, cabe insistir, essa maneira de definir a estratégia pode adquirir um outro estatuto e ter significados bem distintos conforme os autores e as abordagens teóricas utilizadas.

\footnotetext{
${ }^{48}$ Os trabalhos de Garcia Jr. (1983, 1989) e Heredia (1979) constituem bons exemplos de utilização do conceito de estratégias no nível das famílias, mediante a utilização da noção de alternatividade. As estratégias de alternatividade são acionadas pelos pequenos proprietários do sertão nordestino para fazer frente a situações em que sua reprodução esteja ameaçada. Os autores mostram que, em determinadas situações, esses agricultores tomam decisões acerca da utilização da produção de mandioca, que pode ser vendida quando os preços foram atraentes e a demanda doméstica para seu consumo estiver satisfeita como também pode ser deixada na terra ou na propriedade (transformada em farinha), vindo a constituir-se em uma alternativa entre a venda e o consumo. As estratégias de alternatividade também dependem do ciclo demográfico da família, pois quando os filhos são pequenos e somente os pais constituem fonte de força de trabalho, é preferível comercializar a produção agrícola e comprar os produtos de subsistência. À medida que os filhos vão sendo integrados às tarefas agrícolas, essa relação se inverte e novas estratégias tomam assento.
} 


\section{CAPÍTULO3 \\ As transformações estruturais da agricultura e os impactos sobre os mercados de trabalho rurais: a emergência das ocupações não-agrícolas}

É provável que a década de 1980 seja lembrada, no futuro, como nítido divisor de águas, um período que inaugurou marcantes transformações na estrutura da agricultura e em diversas facetas da vida social do mundo rural, em várias regiões agrárias e em diversos países. O modelo produtivo aperfeiçoado pelos países mais desenvolvidos desde as primeiras décadas do século XX e, de modo mais intenso, durante os "anos de ouro" que se seguiram à Segunda Guerra Mundial, passou a defrontar-se com crescentes questionamentos. Esse padrão técnico, genericamente conhecido como "revolução verde", hoje dominante, incorporou os meios de produção desenvolvidos durante a segunda Revolução Industrial, como a mecanização e a utilização de insumos e defensivos agroquímicos, também chamado de "quimificação agrícola", articulando-os a um processo complexo e sofisticado de seleção biológica de plantas e raças animais de alto rendimento (Goodman et al., 1990; Veiga, 1991; Mazoyer e Roudart, 1997). O modelo, amplamente dependente da utilização de fontes de energia fósseis não-renováveis, foi fortemente afetado pelas chamadas "crises do petróleo" da década de 1970, mas este impacto foi rapidamente absorvido, dando impulso a uma nova fase de aperfeiçoamento e, em certos casos, até mesmo de aprofundamento desse padrão.

Os resultados mais gerais desse processo, também denominado pelos franceses de produtivismo, já são amplamente conhecidos, podendo-se afirmar que o aumento da produtividade do trabalho agrícola, a diminuição das populações residentes no campo e o crescimento extraordinário dos volumes de produção estão entre suas características mais notáveis. Em seu livro seminal sobre o século XX, o historiador Eric Hobsbawm (1995, p.284) não deixou de notar que "[...] a mudança social mais impressionante e de mais longo alcance da segunda metade deste século, e que nos isola para sempre do mundo do passado, é a morte do campesinato". Também para ele, há um contraste entre a quan- 
tidade de pessoas que se ocupavam na agricultura até a década de 1950 e o crescimento exponencial dos volumes e da produtividade agrícola.

Outra consequiência importante das transformações produtivas da agricultura na segunda metade do século XX refere-se aos seus impactos sobre o meio ambiente, como a degradação dos solos, a poluição da águas e o devastamento vegetal para a obtenção de novas áreas agricultáveis. A base energética sobre a qual repousa esse modelo produtivo compõe-se de fontes de energia fósseis não-renováveis, o que pode comprometer até mesmo o futuro da humanidade. Em razão disso, a partir dos anos oitenta, muitos estudiosos passaram a reconhecer que os extraordinários avanços tecnológicos e produtivos que ocorreram durante o ciclo expansionista do pós-Guerra na agricultura mundial não foram suficientes para consolidar situações satisfatórias de segurança alimentar e, além disso, constituíam-se em uma ameaça ao equilíbrio ecológico e à preservação da natureza.

Entre os cientistas sociais ligados ao pensamento crítico vem-se fortalecendo a idéia de que a agricultura está sendo submetida a um duplo processo. Por um lado, em sentido vertical, ela estaria cada vez mais integrada ao sistema agroalimentar, no qual as grandes corporações e cadeias do agribusiness desempenham um papel determinante, tanto em relação ao que é produzido como em relação ao tipo de alimento que chega à mesa do consumidor, que cada vez menos é o produto agrícola in natura (Bonano et al., 1994; Goodman e Redclift, 1991; Goodman e Watts, 1996). De outro lado, em sentido horizontal, estaria se consolidando uma nova face socioeconômica do mundo rural, muito pouco ligada à produção agrícola, mas direcionada para aspectos ambientais, de preservação natural e de conservação da paisagem (Munton e Marsden, 1991; Marsden, 1995).

$\mathrm{Na}$ literatura internacional esse processo vem sendo designado de "dualismo". A idéia que perpassa essas avaliações é a de que numa sociedade moderna caberá aos pequenos agricultores o papel de jardineurs de la nature, dedicando-se à preservação ambiental, à manutenção da população no meio rural e ao desenvolvimento de atividades econômicas como o turismo rural, o artesanato e outras com a função principal de conservar a paisagem rural. Somente os grandes proprietários, tecnologicamente modernizados e amplamente integrados ao agri-food-system, terão o papel de produtores rurais ou, na denominação usual da literatura francesa, explotation agricole (Lamarche, 1996).

Mesmo sem concordar com todos os aspectos e implicações suscitados por essa avaliação, parece inequívoco que está em andamento um processo de concentração econômica e de exclusão crescente de determinados grupos sociais da agricultura e do "mundo rural". Nesse sentido, vale a pena resgatar a contribuição de Marsden e sua tentativa de interpretar as transformações ocor- 
ridas na estrutura agrária desde o final da década de 1970 até o período atual, interpretadas como efeitos das mudanças gerais que ocorreram na economia capitalista mundial, decorrentes da crise do fordismo. ${ }^{49}$

Segundo Marsden (1989), o processo global de transformação do capitalismo nos anos recentes caracteriza-se pela "reestruturação produtiva" (1989; Marsden et al., 1993; Marsden, Lowe, Whatmore, 1990). Para Marsden, o processo de reestruturação tem sido estudado, basicamente, por três vertentes distintas. A primeira, baseada na escola francesa da regulação, propõe uma periodização das diferentes fases de regulação do capitalismo na agricultura (Kenney et al., 1991; Allaire e Boyer, 1995). A segunda referese à emergência das formas flexíveis de estruturação na produção industrial, sobretudo em áreas onde se verifica a industrialização difusa ou processos de descentralização industrial (Piore e Sabel, 1984; Harvey, 1993; Bagnasco e Triglia, 1988). A terceira caracteriza-se por insistir na relação da reestruturação com a divisão espacial do trabalho, privilegiando os aspectos geográficos, especialmente no que se refere a seus impactos sobre o mercado de trabalho e as relações com o espaço (Bradley e Lowe, 1984).

A proposta de Marsden, no entanto, é construir uma ponte analítica entre essas interpretações teóricas e a pesquisa empírica, o que implica reconhecer as preocupações dos atores sociais locais. Em uma definição sintética, Marsden (1993, p. 38) definiu a reestruturação como:

O conceito deriva de uma ampla revisão da literatura e, como nós o vemos, seu valor está na sua aplicação à reestruturação do espaço rural. Em particular, o debate em torno de termos como fordismo, pós-fordismo, especialização flexível e as classes de prestadores de serviços, alertam para a importância das transformações nas relações entre a produção e o consumo. Isto nos leva a apreciar os meios pelos quais o espaço rural está sendo "mercantilizado" como resultado das atividades de novas formas de capital, do redirecionamento das ações estatais e das mudanças nos interesses dos consumidores. Também parece evidente que esse processo de "mercantilização" não é simplesmente (quase "magicamente") uma revelação das forças do mercado, ao contrário, ele acarreta disputas, com alguns atores impondo-se como novos representantes do espaço rural.

\footnotetext{
${ }^{49} \mathrm{Na}$ literatura especializada, o fordismo é descrito como um período de acumulação intensiva de capital, iniciado a partir do final da Segunda Guerra, quando se intensifica a produção e o consumo de massa de mercadorias. Esse regime de acumulação intensivo teria entrado em crise a partir da década de 1970 no países capitalistas desenvolvidos provocando mudanças e rearranjos nos processos produtivos. Para maiores informações, consultar Lipietz (1988), Harvey (1993) e Aglietta (1979).
} 
Revisar a extensa bibliografia sobre o tema da reestruturação capitalista escapa aos objetivos aqui perseguidos, não apenas por tratar-se de tarefa ampla e permeada por diferentes enfoques teóricos (para tanto exigiria uma análise longa, judiciosa e detalhada), mas também porque acredita-se que esse esforço desviaria o foco central. Contudo, cabe frisar que essa lacuna não implica a renúncia à avaliação das principais características do processo de reestruturação econômica que afetam a agricultura e o mundo rural, em particular aquelas que dizem respeito ao mercado de trabalho não-agrícola.

Nesse sentido, seguir-se-á apoiando os argumentos de Marsden e colaboradores (1986a, 1993b; Murdoch e Marsden, 1994) de que o processo de reestruturação afeta a estrutura agrária em quatro características centrais. A primeira refere-se à superprodução de produtos agrícolas devido à aceleração do progresso técnico na agricultura e da relativa estabilidade de preços decorrente do apoio e da intervenção do Estado na produção agropecuária dos países desenvolvidos. A segunda refere-se às conseqüências ambientais decorrentes da superprodutividade da agricultura, especialmente no que diz respeito ao seu impacto sobre a paisagem rural. A terceira característica está relacionada ao crescimento desigual da riqueza gerada pelos avanços tecnológicos entre os agricultores e entre as diferentes regiões. E a última característica da reestruturação estaria assentada sobre as mudanças no trabalho familiar agrícola, especialmente no que se refere à emergência da pluriatividade e das atividades não-agrícolas no espaço rural..$^{50}$ Segundo Marsden (1990), conforme já apresentado no capítulo anterior, o crescimento das atividades não-agrícolas e o aumento da pluriatividade das famílias residentes no campo inscreve-se no contexto mais amplo das transformações estruturais das relações de trabalho das sociedades capitalistas no final do século XX.

No que se refere à agricultura e, particularmente, àquela de base familiar, Hervieu parece ter sido o autor que melhor sistematizou o desenvolvimento agrário e seus impactos no mundo rural, desde o final de Segunda Guerra, através da metáfora das "cinco rupturas". Estas seriam responsáveis pelas profundas alterações da face agrária dos países capitalistas mais avançados, criando situações sociais e produtivas inéditas e, em decorrência, desafios antes impensados para o desenvolvimento rural (Hervieu, 1990, 1994). Estas inesperadas alterações em relação aos padrões de desenvolvimento agrário consolidados estão descritas a seguir.

a) ruptura entre agricultura e alimentação: à medida que avança o processo de modernização tecnológica da agricultura ocorre uma dissociação

\footnotetext{
${ }^{50}$ Para uma crítica contundente e bem fundamentada a esse referencial de análise da reestruturação, consultar Goodman e Watts (1994). Para eles, a literatura que analisa a reestruturação do sistema agroalimentar internacional a partir dos mesmos referencias da reestruturação industrial é uma "arquitetura conceitual inadequada".
} 
entre a atividade agrícola (que cada vez mais se torna uma atividade econômica produtora de mercadorias como outra qualquer) e sua função histórica de produzir alimentos;

b) ruptura entre agricultura e território: a partir do pós-Guerra as agriculturas mais avançadas do mundo passam a concentrar a atividade agrícola em zonas específicas, com maior vantagem comparativa, crescendo paralelamente as áreas marginalizadas e abandonadas;

c) ruptura da ordem demográfica: na segunda metade do século $X X$ ocorre uma drástica redução da população ocupada em atividades agrícolas na agricultura mundial, bem como aumenta a idade média dos chefes das unidades rurais. Em razão disso, os próprios agricultores tornam-se habitantes minoritários do espaço rural, provocando uma fissura na idéia de que o rural era sinônimo de atividade agrícola;

d) ruptura entre agricultura e meio ambiente: o intenso progresso tecnológico fundado na moto-mecanização, na quimificação e na introdução de novas variedades de culturas geneticamente melhoradas afetou profundamente a "harmonia" entre o produtor agrícola e sua relação com a natureza. $\mathrm{Na}$ verdade, em muitas situações a própria agricultura vem-se tornando uma ameaça à natureza (poluição da águas, destruição da fauna e flora originais);

e) ruptura do modelo familiar e individualização das propriedades: os estabelecimentos agrícolas dedicados exclusivamente à agricultura utilizam-se crescentemente de tecnologias poupadoras de força de trabalho, tornando-se cada vez mais individualizados. Esses estabelecimentos conservam apenas a aparência de familiares, mas já não funcionam como tais, pois uma parte dos membros da família começa a dedicar-se a outras atividades não-agrícolas, embora permaneça habitando no espaço rural. Uma vez que parcelas crescentes das rendas das famílias rurais passam a não depender das atividades agrícolas stricto sensu, processa-se nessas unidades uma separação entre a alocação da força de trabalho e do patrimônio da família em relação à atividade agrícola. A nova configuração dessas unidades as diferencia da natureza habitual da agricultura familiar.

A seguir, pretende-se abordar as mudanças que ocorrem no emprego agrícola e nas formas de ocupação sob o ângulo das atividades rurais não-agrícolas e de seus efeitos sobre o mercado de trabalho rural, aprofundando o caráter da última "ruptura" apontada por Hervieu. Buscar-se-á mostrar que, a partir do final da década de 1970, o processo de transformação da estrutura agrária não ocorreu apenas como decorrência de incrementos de novas tecnologias e ampliação das escalas de produção, tal como vinha acontecendo desde o final da Segunda Guerra Mundial. O que chama atenção nesse recente processo não é apenas o fato de que a agricultura e sua função de garantir a alimentação estejam deixando de ser a única atribuição do mundo rural. Ao observar a trajetória das nações 
mais desenvolvidas, pode-se verificar que o desenvolvimento rural não se restringe e tempouco é exclusivamente decorrente do aperfeiçoamento tecnológico e produtivo da agricultura.

\subsection{TENDÊNCIAS RECENTES DAS OCUPAÇÕES AGRÍCOLAS ENÃO-AGRÍCOLAS NOS PAÍSES DESẺNVOLVIDOS}

Uma avaliação abrangente das transformações da agricultura nas últimas décadas, na órbita dos países integrantes do chamado capitalismo avançado, certamente enfatizaria os espetaculares ganhos de produtividade e a radical transformação da base tecnológica dos processos produtivos agrícolas. No entanto, se essa avaliação não for meramente do tipo impressionista, também apontará para o diagnóstico dos pesquisadores em várias partes do mundo ocidental, que demonstra que as transformações da agricultura foram socialmente excludentes, provocaram a diminuição abrupta das populações rurais, foram ambientalmente prejudiciais aos ecossistemas naturais, e apesar da elevação da produção, parte considerável da população mundial, inclusive nos países onde a modernização tecnológica foi mais intensa, não conseguem sequer atingir os limites alimentares mínimos.

Mas há outros aspectos das transformações da agricultura e do mundo rural que merecem destaque, especialmente no que se refere às mudanças nas formas de ocupação e de emprego. Nesse sentido, são inúmeros os trabalhos que apontam para o crescimento das atividades não-agrícolas no meio rural, refletindo uma inusitada tendência ocupacional nestas áreas ${ }^{51} \mathrm{O}$ ineditismo desses trabalhos reside justamente no fato de que, embora timidamente, se reconheça que, em determinadas situações históricas e contextos regionais, a agricultura deixa de ser o exclusivo sinônimo de "rural". Estudo relevante, que se destaca pela sua abrangência, é um recente relatório da OCDE (1996). Este documento indica que, mesmo nas regiões chamadas "essencialmente rurais", são os setores não-agrícolas que oferecem, crescentemente, as maiores possibilidades de emprego no meio rural, destacando-se, entre os países listados, que nessas regiões apenas o Canadá apresentou taxas de crescimento positivas do emprego rural, conforme mostra a Tabela $1 .{ }^{52}$ No geral, no entanto, salientam-

\footnotetext{
${ }^{51}$ A pesquisa mais ampla nesse sentido foi realizada por uma equipe interdisciplinar chamada Arkleton Trust Project (1992).

${ }^{52}$ A OCDE considera como "regiões rurais" as communautés onde a densidade da população é inferior a $150 \mathrm{hab} / \mathrm{km}^{2}$, exceto para o Japão onde passa para $500 \mathrm{hab} / \mathrm{km}^{2}$. Para facilitar a análise, as 2 mil regiões da OCDE foram reagrupadas em três subcategorias de acordo com a parte da população regional que vive nas communautés rurais, conforme segue: regiões Essencialmente Rurais (ER): áreas de fraca densidade demográfica, onde em mais de $50 \%$ da área regional a densidade demográfica é inferior a $150 \mathrm{hab} / \mathrm{km}^{2}$; Relativamente Rurais (RR): áreas de média densidade demográfica, onde entre $15 \%$ e $50 \%$ da população vive em áreas onde a densidade demográfica é inferior a $150 \mathrm{hab} / \mathrm{km}^{2}$; Essencialmente Urbanas (EU): áreas de alta densidade demo-
} 
se as taxas negativas em todos os países e para as três categorias indicadas. Nas regiões chamadas "essencialmente rurais" dos países membros da organização, segundo é acentuado, o emprego agrícola está em declínio não somente em termos relativos mas também absolutos (OCDE, 1996, p.45).

\section{Tabela 1 \\ PAÍSES SELECIONADOS DA OCDE.TAXA DECRESCIMENTO \\ ANUAL DO EMPREGO, 1980-1990 \\ (\% de variação anual)}

\begin{tabular}{|l|c|c|c|c|c|c|c|c|}
\hline \multicolumn{3}{c}{$\begin{array}{c}\text { Média } \\
\text { nacional }\end{array}$} & \multicolumn{2}{c|}{$\begin{array}{c}\text { Regiões } \\
\text { essencialmente } \\
\text { rurais }\end{array}$} & \multicolumn{2}{c|}{$\begin{array}{c}\text { Regiões } \\
\text { relativamente } \\
\text { rurais }\end{array}$} & \multicolumn{2}{c|}{$\begin{array}{c}\text { Regiões } \\
\text { essencialmente } \\
\text { urbanas }\end{array}$} \\
\hline & Agrícola & $\begin{array}{c}\text { Não- } \\
\text { agrícola }\end{array}$ & Agrícola & $\begin{array}{c}\text { Não- } \\
\text { agrícola }\end{array}$ & Agrícola & $\begin{array}{c}\text { Não- } \\
\text { agrícola }\end{array}$ & Agrícola & $\begin{array}{c}\text { Não- } \\
\text { agrícola }\end{array}$ \\
\hline Canadá & 0.4 & 1.6 & 0.2 & 1.5 & 0.2 & 2.4 & 1.9 & 1.3 \\
Estados Unidos & -0.3 & 1.8 & -1.3 & 1.5 & 0.8 & 2.0 & 2.8 & 1.9 \\
Austrália & -1.7 & 1.4 & -2.0 & 1.7 & -0.9 & 1.8 & -1.0 & 1.1 \\
Japão & -3.3 & 1.4 & -3.1 & 0.8 & -3.4 & 1.3 & -3.2 & 1.8 \\
Nova Zelândia & -0.4 & 0.2 & -0.6 & -0.1 & -0.1 & -0.1 & 0.9 & 1.0 \\
Áustria & -3.1 & 0.7 & -3.4 & 0.9 & -2.5 & 0.9 & -1.6 & 0.4 \\
Bélgica & -1.6 & 0.2 & -1.3 & 0.6 & -1.6 & -0.3 & -1.7 & 0.3 \\
Finlândia & -3.4 & 0.9 & -3.5 & 0.6 & -3.3 & 0.6 & -0.8 & 1.9 \\
França & -4.0 & 0.8 & -4.2 & 0.7 & -3.8 & 1.0 & -3.5 & 0.5 \\
Irlanda & -1.7 & 0.5 & -2.1 & 0.7 & -1.3 & 0.4 & -0.3 & 0.3 \\
Holanda & 0.9 & 2.7 & - & - & -1.4 & 3.3 & 1.6 & 2.6 \\
República & -0.3 & 0.2 & -0.7 & 0.2 & -0.3 & 0.1 & 2.5 & 0.2 \\
Tcheca & -2.1 & 1.1 & -1.1 & 1.3 & -2.8 & 0.2 & -1.7 & 1.8 \\
Espanha & -3.1 & 1.3 & -3.0 & 1.3 & -3.6 & 1.3 & -2.3 & 1.4 \\
Suécia & -2.7 & 1.8 & -3.2 & 2.1 & -2.9 & 2.4 & -2.0 & 1.5 \\
\hline
\end{tabular}

Nota: ( - ) Não-aplicável.

Fonte: OCDE (1996, p. 120). ${ }^{53}$

Também chama atenção a razão inversa da variação do emprego agrícola em relação ao percentual de participação do emprego não-agrícola. $\mathrm{Na}$ maioria dos países selecionados da OCDE, conforme mostra a tabela, a taxa de utilização da mão-de-obra diretamente ocupada na agricultura caiu, consi-

gráfica, onde menos de $15 \%$ da população vive em áreas onde a densidade demográfica é inferior a $150 \mathrm{hab} / \mathrm{km}^{2}$ (ou seja, $85 \%$ da população vive em áreas onde a densidade demográfica é superior a $150 \mathrm{hab} / \mathrm{km}^{2}$ ). Segundo esta definição, em torno de um terço da população dos países da $\operatorname{OCDE}(35 \%)$ vive nas comunidades rurais ("essencialmente" ou "relativamente" rurais), representando mais de $90 \%$ do território coberto pelos integrantes da OCDE.

${ }^{53}$ No citado estudo da OCDE (1996) não são apresentados os valores absolutos, apenas as taxas de crescimento. 
deravelmente, na média nacional, atingindo o máximo (em torno de $4 \%$ ao ano) no caso francês, nos anos oitenta. O emprego não-agrícola, pelo contrário, registrou taxas positivas de crescimento na maioria dos países. A surpresa não está na diminuição do emprego agrícola, mas na capacidade de desenvolvimento de novas atividades empregadoras no espaço rural que, às vezes, possuem pouca ou nenhum ligação direta com a agricultura. Entre outras conclusões, tais informações demonstram que restringir o espaço rural à agricultura tout court pode significar um reducionismo, que os processos sociais e econômicos vêm-se encarregando de desmentir. Por outro lado, contudo, o crescimento das atividades não-agrícolas no espaço rural não deve ser interpretado, de forma apressada, como uma perda da importância das atividades propriamente agrícolas. Na verdade, o que se verifica é um processo de diversificação produtiva nesses espaços, provavelmente relacionado com o crescimento da mercantilização econômica e social.

Na década passada, em alguns países selecionados, o total do emprego agrícola nas zonas "essencialmente rurais" da OCDE (conforme a conceituação) decresceu em quase todos os casos - novamente com a exceção canadense -, chegando, em diversos países, a ocorrer uma redução de um quarto ou mais do emprego rural nessas zonas. Importante notar, da mesma forma, que além da queda da ocupação na agricultura, nas atividades de cunho industrial o desempenho para a criação de novos empregos nas regiões "essencialmente rurais" também é negativo. O estudo da OCDE revela que o setor que mais contribuiu com o incremento de empregos nas áreas consideradas "essencialmente rurais" foi o de serviços.

Outro aspecto importante que o estudo citado evidencia, ao analisar com indicadores territoriais e demográficos o emprego e as formas de ocupação nas zonas rurais, refere-se à relação inversa entre a distribuição espacial e o emprego da população. Ou seja, embora boa parte da população permaneça morando em áreas rurais, sua ocupação principal não está diretamente relacionada à agricultura. A Tabela 2 mostra que, na maior parte dos países analisados, uma parcela muito expressiva da população ainda se concentra em áreas onde a densidade demográfica é inferior a $150 \mathrm{hab} / \mathrm{km}^{2}$. No conjunto dos países relacionados, parcelas significativas da população residem nessas áreas consideradas "essencialmente rurais", havendo inclusive países onde mais da metade da população total reside em zonas de baixa densidade, como é o caso da Noruega. 
Tabela 2

PAÍSES SELECIONADOS DA OCDE. POPULAÇÃORURAL E SITUAÇÃO DE DOMICÍLIOS EM PAÍSES MEMBROS DAOCDE, 1990

\begin{tabular}{|c|c|c|c|c|}
\hline \multirow{2}{*}{$\begin{array}{c}\text { População das } \\
\text { comunidades } \\
\text { rurais }\end{array}$} & \multirow[b]{2}{*}{$\begin{array}{l}\text { Média } \\
\text { nacional }\end{array}$} & \multicolumn{3}{|c|}{ \% da população por tipo de região } \\
\hline & & $\begin{array}{l}\text { Essencialmente } \\
\text { rural }\end{array}$ & $\begin{array}{l}\text { Relativamente } \\
\text { rural }\end{array}$ & $\begin{array}{c}\text { Essencialmente } \\
\text { urbana }\end{array}$ \\
\hline Noruega & 59 & 51 & 38 & 11 \\
\hline Suécia & 43 & 49 & 32 & 19 \\
\hline Finlândia & 55 & 43 & 37 & 20 \\
\hline Dinamarca & 42 & 40 & 38 & 22 \\
\hline Áustria & 42 & 40 & 39 & 22 \\
\hline Estados Unidos & 44 & 36 & 34 & 30 \\
\hline Canadá & 40 & 33 & 23 & 44 \\
\hline Austrália & 30 & 23 & 22 & 55 \\
\hline Portugal & 36 & 35 & 22 & 43 \\
\hline República Tcheca & 29 & 15 & 57 & 28 \\
\hline França & 37 & 30 & 41 & 29 \\
\hline Espanha & 30 & 17 & 46 & 37 \\
\hline Itália & 22 & 9 & 44 & 47 \\
\hline Japão & 27 & 22 & 35 & 43 \\
\hline Suíça & 19 & 13 & 25 & 62 \\
\hline Alemanha & 21 & 8 & 26 & 66 \\
\hline Reino Unido & 13 & 1 & 27 & 72 \\
\hline Bélgica & 9 & 2 & 18 & 80 \\
\hline Holanda & 8 & - & 15 & 85 \\
\hline
\end{tabular}

Notas: (-) Sem aplicação. Tipologia baseada na proporção da população regional ativa das comunidades rurais.

Fonte: OCDE (1996, p. 20).

Entretanto, confrontando-se os dados da tabela anterior com os apresentados na Tabela 3, a seguir, verifica-se que a participação da agricultura no emprego regional, mesmo nas áreas "essencialmente rurais", é relativamente reduzida e, à exceção do caso da Espanha, não atinge sequer um quarto do emprego total. Essas informações reafirmam que a proporção da população que habita as áreas rurais é significativamente superior ao que representa a agricultura na geração setorial de empregos. Os casos mais emblemáticos talvez sejam o dos Estados Unidos e o da França, reconhecidamente grandes produtores agrícolas. Nestes países, a agricultura é responsável por apenas 3,3\% e 5,7\%, respectivamente, dos empregos em relação à média nacional (chegando a 5,9\% no caso americano e $10,8 \%$ no francês, quando consideradas apenas as regiões essencialmente rurais). No 
entanto, conforme indicado na Tabela 2 , a população considerada rural alcança, na média nacional, $44 \%$ e $37 \%$, respectivamente (36\% e $30 \%$ nas zonas essencialmente rurais), mostrando que não há uma relação direta entre o domicílio rural e a ocupação na agricultura.

Tabela 3

PAÍSES SELECIONADOS DAOCDE.PARTICIPAÇÃO

DAAGRICULTURANOEMPREGOREGIONAL, 1990

(\% do emprego total)

\begin{tabular}{|l|c|c|c|c|}
\hline \multicolumn{1}{|c|}{ Países } & $\begin{array}{c}\text { Média } \\
\text { nacional }\end{array}$ & $\begin{array}{c}\text { Regiões } \\
\text { essencialmente } \\
\text { rurais }\end{array}$ & $\begin{array}{c}\text { Regiões } \\
\text { relativamente } \\
\text { rurais }\end{array}$ & $\begin{array}{c}\text { Regiões } \\
\text { essencialmente } \\
\text { urbanas }\end{array}$ \\
\hline Canadá & 4.6 & 10.9 & 3.3 & 1.2 \\
Estados Unidos & 3.3 & 5.9 & 2.4 & 1.6 \\
Austrália & 4.5 & 14.7 & 4.3 & 0.7 \\
Japão & 7.1 & 14.1 & 8.5 & 2.4 \\
Áustria & 6.2 & 13.3 & 4.1 & 0.8 \\
Bélgica & 2.5 & 9.3 & 3.0 & 2.2 \\
Dinamarca & 5.7 & 9.5 & 4.8 & 0.4 \\
Finlândia & 8.5 & 16.0 & 5.3 & 0.7 \\
França & 5.7 & 10.8 & 5.5 & 1.0 \\
Itália & 9.9 & 16.0 & 13.5 & 5.7 \\
Holanda & 4.6 & - & 6.5 & 4.3 \\
Portugal & 10.6 & 22.9 & 10.0 & 2.8 \\
República Tcheca & 11.6 & 22.3 & 13.1 & 2.7 \\
Espanha & 11.1 & 25.0 & 13.8 & 2.6 \\
Suécia & 3.7 & 5.4 & 2.9 & 0.7 \\
Sú́ça & 4.1 & 9.5 & 6.3 & 2.1 \\
Reino Unido & 2.4 & 10.3 & 4.2 & 1.0 \\
\hline
\end{tabular}

Notas: (-) Não-aplicável.

Fonte: OCDE (1996, p.118).

Os dados aqui descritos sinteticamente parecem ser suficientes para se afirmar que o recurso ao trabalho não-agrícola, por parte de membros das famílias que habitam áreas rurais, nas nações citadas, não pode ser considerado como uma situação efêmera ou transitória. Nesse sentido, as mudanças atualmente em curso parecem indicar que o desenvolvimento social e econômico do mundo rural passa por redefinições que apontam não apenas para a emergência de novas formas de obtenção de rendas (essencialmente não- 
agrícolas) para os agricultores e os habitantes do espaço rural, mas talvez até mesmo uma nova via para sua inserção na divisão social do trabalho.

Entre as razões apontadas em diversos estudos, que teriam contribuído para a emergência e a expansão das atividades não-agrícolas nos países desenvolvidos, destacam-se pelo menos cinco fatores principais:

a) A modernização tecnológica: o primeiro deles refere-se ao disseminado e intenso processo de modernização tecnológica da agricultura. $\mathrm{Na}$ literatura especializada, a expressão "produtivismo" tornou-se sinônimo do processo de intensificação dos sistemas produtivos agrícolas baseados no uso de tecnologias e insumos de origem industrial (Lamarche, 1996). Entre as consequiências mais salientes do produtivismo destaca-se a "superprodução", que é o resultado da corrida tecnológica e produtiva entre os agricultores, estimulados através de uma política de subsídio via garantia de preços mínimos do governo, na qual a rentabilidade da atividade agrícola passa a estar diretamente associada à produtividade e aos volumes alcançados pelos produtores, o que desencadeia um processo de concorrência pelo incremento constante do progresso tecnológico pelos agricultores. Em um contexto de expansão da demanda por alimentos, como o que se seguiu ao final da Segunda Guerra e estendeu-se até meados dos anos setenta na Europa, praticamente inexistiam barreiras à ampliação da produtividade agrícola.

O resultado dessa política levou a uma "crise de superprodução" agrícola, decorrente do crescimento constante da produtividade e do inchaço dos estoques estatais de produtos agrícolas, que nem mesmo medidas de contenção, como as cotas de produção por produtor, instituídas no início dos anos oitenta, conseguiram reduzir. Além disso, essa corrida "produtivista" foi extremamente seletiva, implicando a formação de uma elite de agricultores privilegiados, cujo sucesso passou a ligar-se intimamente aos subsídios estatais. Isso gerou um processo de êxodo e migração do campo, e até mesmo de "desertificação" social em determinadas áreas rurais que eram menos apropriadas para praticar essa agricultura competitiva.

Esse processo de modernização tecnológica, acompanhado do corolário ideológico "produtivista”, permitiu que a agricultura das nações desenvolvidas se tornasse uma atividade desempenhada por "agricultores profissionais", cujo objetivo era a maximização da utilização dos fatores. Os dados da Tabela 4, a seguir, mostram alguns dos principais resultados desse padrão produtivo a partir do qual os países da Comunidade Européia alcançaram a auto-suficiência alimentar. Os dados revelam que, embora tenha aumentado o tamanho médio das propriedades, a agricultura tornou-se uma atividade cada vez mais individualizada, dispensando gradualmente a necessidade de utilização plena da mãode-obra de todos os membros da família rural. Entre 1975 e 1987, o número de 
propriedades diminuiu $16 \%$ nos nove países da CEE e o número de pessoas trabalhando na agricultura reduziu-se em $17 \%$, significando uma perda de 2,2 milhões de pessoas no campo (Fuller e Brun, 1988).

\section{Tabela 4 \\ PROPRIEDADES AGRÍCOLAS DAEUROPA. ${ }^{1}$ ESTATÍSTICAS SELECIONADAS, 1975-1985}

\begin{tabular}{|c|c|c|c|}
\hline Propriedades agrícolas da Europa & 1975 & 1985 & $\begin{array}{c}\% \text { de } \\
\text { variação }\end{array}$ \\
\hline Nún & 5,1 & 4,3 & $-16 \%$ \\
\hline Sup & 86,5 & 83,0 & $-4 c$ \\
\hline (ha) & 17,0 & 19,3 & $+14 \%$ \\
\hline $\begin{array}{l}\text { Pessoas que trabalham na propriedade }{ }^{2} \\
\text { (em milhões) }\end{array}$ & 12,7 & 10,5 & $-17 \%$ \\
\hline $\begin{array}{l}\text { Equivalente a tempo integral em } \mathrm{UTA}^{3} \\
\text { (em milhões) }\end{array}$ & 7,5 & 5,7 & $-24 \%$ \\
\hline
\end{tabular}

${ }^{1}$ Os dados se referem à Bélgica, França, Itália, Luxemburgo, Holanda, Alemanha, Dinamarca, Irlanda, Reino Unido.

${ }^{2}$ Excluindo-se a mão-de-obra ocasional que não faz parte da família.

${ }^{3}$ UTA - Unidade de Trabalho Anual (em princípio, 2.200 horas anuais, ressalvados os acordos nacionais)

Fonte: Arkleton Trust (1992, p. 90).

Na França, que se tornou o segundo maior exportador mundial de produtos agrícolas e o primeiro fornecedor da CEE, a população agrícola ativa caiu de 2,4 pessoas por propriedade rural em 1970, para a média de 1,4 pessoas em 1993. Entre 1970 e 1985, o conjunto da população agrícola ativa francesa caiu de 15\% para 7\%.Em relação às esposas dos agricultores franceses, em 1970,84\% delas participavam diretamente dos trabalhos da propriedade, mas em 1993 essa cifra não chegava a 60\% (Hervieu, 1996a,p. 10). Em 1995, do total das pessoas ocupadas na atividade agrícola, $50 \%$ era de chefes, $8 \%$ de assalariados, $18 \%$ de outros membros da família e apenas $24 \%$ de cônjuges. A Tabela 5 fornece uma visão de conjunto desse processo de diminuição da população economicamente ativa na agricultura francesa. O que chama atenção nesta tabela são os índices negativos de variação anual do número de pessoas ocupadas na atividade agrícola desde o início da década de 1970, reforçando a argumentação anterior de que estava em curso, simultaneamente, um processo de concentração social e econômica da estrutura agrária francesa, aliado à diminuição crescente do número de pessoas dedicadas a essas tarefas (Hervieu, 1996, p.11). 
Tabela 5

EVOLUÇÃO DAPOPULAÇÃO AGRÍCOLAATIVANAFRANÇA1970A 1993

\begin{tabular}{|l|c|c|c|c|c|c|c|}
\hline \multirow{2}{*}{ Efetivos (1.000) } & \multicolumn{4}{|c|}{ Períodos } & \multicolumn{3}{c|}{$\begin{array}{c}\text { Taxa anual média } \\
\text { de variação (\%) }\end{array}$} \\
\cline { 2 - 8 } & 1970 & 1979 & 1988 & 1993 & $70 / 79$ & $79 / 88$ & $88 / 93$ \\
\hline Chefes & 1.588 & 1.263 & 1.017 & 801 & $-2,5$ & $-2,4$ & $-4,7$ \\
Cônjuges & 1.052 & 730 & 507 & 378 & $-4,0$ & $-4,0$ & $-5,7$ \\
Outros membros da família & 872 & 462 & 346 & 293 & $-6,8$ & $-3,2$ & $-3,3$ \\
Total dos ativos das famílias & 3.512 & 2.455 & 1.870 & 1.472 & $-3,9$ & $-3,0$ & $-4,7$ \\
Assalariados permanentes & 335 & 211 & 156 & 136 & $-5,0$ & $-3,3$ & $-2,7$ \\
Total ativos permanentes & 3.847 & 2.688 & 2.026 & 1.608 & $-4,0$ & $-3,0$ & $-4,5$ \\
\hline
\end{tabular}

Fonte: Hervieu (1996a, p. 11).

b) A queda das rendas agrícolas: o segundo fator responsável pela emergência das atividades não-agrícolas deve-se à diminuição das rendas agrícolas, nos países desenvolvidos, a partir de meados da década de 1970. O crescimento da produtividade agrícola e do volume global de produção da agricultura nos países desenvolvidos, particularmente na segunda metade do século XX, teve por base no financiamento da produção agrícola e o estímulo das políticas públicas destinadas a desenvolver os formatos tecnológicos dos sistemas produtivos. Essa ação permitiu um forte incremento na produtividade agrícola que, em países como a França, chegou a ser de $3,3 \%$ ao ano, entre 1949 e 1962, e 2,5\% ao ano, entre 1962 e 1972 (Eizner, 1985, p. 20). A Tabela 6 ilustra os índices de crescimento da produtividade do leite e dos cereais, em alguns países da Europa.

Tabela 6

EVOLUÇÃO DOS RENDIMENTOS DE LEITE E CEREAIS EM PAÍSES SELECIONADOS - 1958-1972

\begin{tabular}{|l|c|c|c|c|c|}
\hline Produtividade técnica & Alemanha & França & Itália & Holanda & Bélgica \\
\hline Rendimento leite (kg/vaca) & $+34 \%$ & $+42 \%$ & $+64 \%$ & $+16 \%$ & $+9 \%$ \\
$\begin{array}{l}\text { Variação 1957 a 1952 } \\
\text { Rendimento cereais (kg/ha) }\end{array}$ & $+48 \%$ & $+87 \%$ & $+52 \%$ & $+45 \%$ & $+42 \%$ \\
Variação 1956/60 a 1973/74 & $+5 \%$ \\
\hline
\end{tabular}

Fonte: Kroll citado por Abramovay (1992, p.183). 
Esse expressivo crescimento induziu o incremento patrimonial das famílias rurais na forma de maquinarias e estruturas de produção diversas e, assim, por um longo período, constituiu-se na principal forma de garantia da relativa paridade de rendimentos entre a agricultura e as atividades econômicas não-agrícolas. Entretanto, o crescimento patrimonial não foi acompanhado pela evolução da rentabilidade da atividade agrícola.

Segundo Blanc; Brum; Delord; e Lacombe (1990, p. 316), o declínio da rentabilidade do setor agrícola e o aumento das famílias de agricultores que possuíam mais de uma fonte de renda além da agricultura não apenas comprometeram o desempenho econômico da agricultura mas, sobretudo, acabaram minando a identidade e o "modelo de agricultor" que se desejava formar com base nas seguinte igualdade: uma família = uma proprieda$\mathrm{de}=$ uma renda $=$ uma atividade $=$ um patrimônio. A partir de meados da década de 1970, o agricultor profissional (a exploitation agricole, segundo os franceses), por mais modernizada e tecnificada que fosse sua propriedade, começou a perceber que seus níveis de renda dependiam mais dos subsídios estatais concedidos pelos governos do que da excelência de sua escala produtividade.

c) Políticas públicas: o terceiro fator que contribuiu para a emergência e reconhecimento da pluriatividade nos países desenvolvidos está relacionado ao apoio e o estímulo das políticas públicas, que passaram a ser oferecidos pela União Européia, a partir da grande reforma da Política Agrícola Comum (PAC), ocorrida em 1991-1992..$^{4}$ Essas reformas não visaram apenas reduzir os estoques governamentais de produtos agrícolas, decorrente da política de subsídios, mas também se contrapor à queda das rendas no setor agrícola como uma estratégia de "desintensificação" da atividade agrícola. Em um cenário no qual o desemprego, sobretudo o urbano-industrial, havia se tornado um problema estrutural sem perspectivas rápidas de resolução, a busca de novas formas de ocupação no meio rural também passou a figurar entre os objetivos das políticas públicas. Preservar os empregos não-agrícolas nas áreas rurais tornou-se então uma maneira eficaz de combater as disparidades de renda entre as regiões e entre a cidade e o campo. Por essa via, o meio rural

\footnotetext{
${ }^{54}$ Para uma avaliação aprofundada dessa reforma, consultar Abramovay (1999). A Política Agrícola Comum (PAC) surgiu a partir do Tratado de Roma, assinado em 1957, que previa o establecimento de um política agrícola comum (Artigo 39) entre os primeiros signatários da Comuidade Econômica Européia (CEE), formada então por Bélgica, França, Itália, Holanda, Luxemburgo e Alemanha. Em 1958, na Conferência de Stressa, inicia-se o processo de compatibilização das políticas agrícolas nacionais e, em 1962, é aprovada a Lei de Orientação, que cria o Fundo Europeu de Orientação e Garantia Agrícola (FEOGA), que será o principal mecanismo de financiamento da PAC e de protecionismo para a agricultura européia. Em 1973, aderiram à CEE a Dinamarca, a Irlanda, o Reino Unido, em 1981, a Grécia, em 1986, Portugal e Espanha e, por fim, em 1995, Áustria, Suécia e Finlândia. Atualmentre a CEE chama-se União Européia.
} 
passou a ser área de atuação de setores governamentais, que até então lhe dedicavam pouca ou nenhuma atenção, particularmente no caso da infra-estrutura e dos serviços sociais básicos.

Segundo Brun e Fuller (1991, p.10), em razão dos crescentes desequilíbrios e questionamentos, nos primeiros anos da década de 1980, vários especialistas chegaram à conclusão que a PAC caminhava para um impasse. Com a publicação do "Livro Verde" (na verdade, um relatório sobre os principais dilemas da política agrícola), em 1985, afloraram as discussões sobre a necessidade de reformar a política agrícola européia, especialmente em relação à redefinição da política de preços.

Nesse contexto, generaliza-se na Europa a percepção de que era preciso repensar o desenvolvimento rural tornando-o compatível com a garantia da segurança alimentar, do aporte justo de rendimentos ao agricultores e, sobretudo, comprometido com a sustentabilidade e a proteção ambiental. Assim, o problema dos altos custos financeiros de sustentação da política agrícola (subsídios e protecionismo) une-se aos problemas comerciais (crise do comércio mundial, baixa de preços, superprodução), sociais (migração rural-urbana, baixas rendas dos agricultores) e ambientais (degradação do ambiente, poluição das águas, uso intensivo de agrotóxicos), resultando na convergência de argumentos suficientemente fortes para dar início a um processo de reestruturação do padrão de produção agrícola vigente até então.

Essa tomada de consciência contingente desemboca na reforma da PAC de 1992 e acaba tendo um efeito decisivo no estímulo à pluriatividade e ao desenvolvimento econômico regional e descentralizado. ${ }^{55}$ Através de vários programas, muitas pequenas localidades rurais tiveram acesso a serviços que antes não possuíam e presenciaram uma significativa melhora na infra-estrutura local. Desse modo, recuperaram não apenas sua dinâmica econômica mas também sua vitalidade social. Nessas localidades, a pluriatividade passou a ser reconhecida pelos órgãos públicos como uma estratégia para ajudar a resolver os problemas das baixas rendas dos agricultores e, até mesmo, como uma alternativa a própria atividade agrícola.

\footnotetext{
${ }^{55}$ A partir de 1992 uma parte crescente da seção de orientação do FEOGA passou a ser destinada aos fundos estruturais, que prevêem ajuda ao desenvolvimento rural com medidas do tipo Objetivo 5a: acelerar a "adaptação das estruturas agrícolas", financiado tanto pela seção Garantia como pela seção Orientação do FEOGA; e Objetivo 5 b: "promover o desenvolvimento das zonas rurais" buscando a diversificação das atividades no meio rural, financiado basicamente pelo FEOGA-Orientação. O programa LEADER (Liasions entre actions de développement de l'économie rurale), lançado em 1991, é um exemplo dessas novas políticas públicas. Seu objetivo é constituir-se em modelo alternativo de desenvolvimento e estímulo às iniciativas locais de desenvolvimento rural nas regiões de atuação dos objetivos 1 e 5 b. Para uma análise aprofundada do Programa LEADER consultar Smith (1995)
} 
d) A dinâmica do mercado de trabalho: a expansão da pluriatividade e das atividades não-agrícolas no meio rural dos países desenvolvidos também pode ser atribuída à dinâmica do mercado de trabalho não-agrícola. Nesse sentido, existem vários estudos que indicam as relações entre processos de descentralização industrial ou de industrialização descentralizada em áreas não-urbanas com o crescimento de atividades não-agrícolas nos espaços rurais.$^{56}$ Este é o caso, em particular, de algumas regiões do Mediterrâneo, especialmente em países como Portugal, Espanha e Itália.

No caso português, Reis, Hespanha, Pires e Jacinto (1990) constataram que a pluriatividade das famílias que residem no meio rural está relacionada ao processo mais amplo de realocação e reestruturação das economias industriais. Assim, a pluriatividade expressaria a nova natureza das relações de trabalho em uma sociedade em mutação, na qual os processos de descentralização das indústrias acabam superando os obstáculos que o espaço rural lhes oferecia. Em outro trabalho, Reis (1985, p.233) mostrou que em Portugal, nas regiões onde se verificaram processos recentes de industrialização, a pluriatividade tornou-se um traço marcante da classe trabalhadora passando a integrar o próprio “[...] modo da reprodução de força de trabalho industrial. Nesse sentido, ela desempenha o papel de rebaixar os custos de reprodução da força de trabalho, mediante o aporte de recursos complementares ao orçamento das famílias, obtido fora da propriedade agrícola.

Na Itália, os estudos de Bagnasco (1996), Garofoli (1993) e Sarraceno $(1987,1994 a, 1994 c)$ mostram o papel que a agricultura familiar desempenha nos processos de industrialização difusa e de descentralização industrial. Para os autores, não se deve destacar apenas a força de trabalho que os agricultores pluriativos fornecem às indústrias, mas o ambiente social e institucional que se forma nas localidades que conhecem semelhante processo de industrialização e do qual as empresas se beneficiam. Segundo os autores, a maior homogeneidade social e econômica existente nas áreas rurais onde se estabelecem as indústrias acaba servindo como uma espécie de vantagem competitiva, seja pelo fato de empregar uma mão-de-obra com menor mobilidade, seja pela sua flexibilidade.

e) Pluriatividade como característica estrutural da agricultura familiar: como último fator, pode-se dizer que a emergência da pluriatividade e sua vinculação com o exercício de várias atividades dentro de uma mesma propriedade agrícola é uma característica intrínseca ao "modo de funciona-

\footnotetext{
${ }^{56}$ É volumosa a bibliografia que poderia ser citada sobre o tema. Consulte-se, entre tantos, os estudos de Courlet $(1993,1995)$ e, principalmente, Bagnasco (1996).
} 
mento" de unidades de trabalho que se organizam sob a égide do trabalho familiar, conforme amplamente demonstrado pelas Ciências Sociais dedicadas aos processos sociais agrários, a Antropologia em particular. Como na agricultura das nações desenvolvidas o trabalho de origem familiar é dominante, pode-se dizer que o fato dessas unidades voltarem-se para o exercício de outras atividades, combinando-as com a agricultura, responde a uma situação corriqueira. Isso nos permite entender, por exemplo, a forte presença dos ouvrier-paysan na estrutura agrária francesa e européia em geral, nas quais o trabalho externo, complementar ou mesmo temporário, e mesmo no interior da propriedade (através do artesanato e outras atividades não-agrícolas), desempenhado pelos camponeses, fazia parte do cotidiano dessas categorias.

Os argumentos até aqui expostos contribuem para entender por que, em alguns dos principais países analisados no relatório da OCDE (1996), a agricultura em tempo-parcial e a pluriatividade ocupam um lugar de destaque na estrutura do emprego e da ocupação em áreas rurais, conforme mostra a Tabela 7. Essa importânciaé ainda mais significativa nas regiões "essencialmente rurais" e "relativamente rurais", reforçando os argumentos já apresentados anteriormente..$^{57}$

\footnotetext{
${ }^{57}$ Nesse estudo, a OCDE (1996, p. 123) faz uma distinção entre agricultura em tempo parcial e pluriatividade nos seguintes termos: "[...] considera-se como trabalhadores em tempo parcial todos os proprietários que trabalham menos de uma unidade de trabalho-homem ao ano, quaisquer que sejam as atividades lucrativas que possam exercer. Os proprietários agrícolas pluriativos são pessoas que trabalham em tempo parcial na agricultura e que exercem paralelamente outras atividades lucrativas".
} 
Tabela 7

PAÍSES SELECIONADOS DA OCDE.PROPORÇÕES

DEESTABELECIMENTOS AGRÍCOLAS COMRESPONSÁVEIS

EMTEMPO PARCIALE PLURIATIVOS, $1990^{1}$ (\%)

\begin{tabular}{|l|c|c|c|c|}
\hline & $\begin{array}{c}\text { Média } \\
\text { nacional }\end{array}$ & $\begin{array}{c}\text { Regiões } \\
\text { essencialmente } \\
\text { rurais }\end{array}$ & $\begin{array}{c}\text { Regiões } \\
\text { relativamente } \\
\text { rurais }\end{array}$ & $\begin{array}{c}\text { Regiões } \\
\text { essencialmente } \\
\text { urbanas }\end{array}$ \\
\hline \multicolumn{5}{|c|}{ Estabelecimentos agrícolas em tempo parcial } \\
\hline Canadá & 56 & 56 & 56 & 46 \\
Estados Unidos & 33 & 37 & 30 & 34 \\
Japão & 84 & 82 & 85 & 85 \\
Áustria & 60 & 59 & 60 & 57 \\
França & 50 & 47 & 51 & 36 \\
Alemanha & 59 & 58 & 59 & 60 \\
Itália & 89 & 90 & 88 & 89 \\
Holanda & 32 & - & 30 & 33 \\
Portugal & 78 & 82 & 75 & 58 \\
Espanha & 80 & 80 & 78 & 87 \\
Reino Unido & 44 & 42 & 44 & 46 \\
\hline \multicolumn{5}{|c|}{ Estabelecimentos agrícolas pluriativos } \\
\hline Canadá & 42 & 43 & 38 & 36 \\
Áustria & 35 & 35 & 34 & 28 \\
França & 24 & 22 & 24 & 17 \\
Alemanha & 44 & 44 & 45 & 43 \\
Itália & 30 & 30 & 29 & 32 \\
Holanda & 22 & - & 17 & 24 \\
Portugal & 36 & 34 & 42 & 28 \\
Espanha & 35 & 32 & 33 & 37 \\
Reino Unido & 30 & 31 & 27 & 33 \\
\hline
\end{tabular}

Notas: (-) Sem aplicação.

${ }^{1}$ Os dados para os países da União Européia são de 1989.

Fonte: OCDE (1996).

\subsection{AEVOLUÇÃODAS OCUPAÇÕES RURAIS NÃO-AGRÍCOLAS NAAMÉRICALATINA}

Nos anos recentes, o estudo das ocupações rurais não-agrícolas ganhou destaque entre os estudiosos do desenvolvimento rural, particularmente aqueles que se interessam pelos problemas dos países latino-americanos. Duas publicações recentes, entre tantas outras que poderiam ser citadas, oferecem um panorama geral do debate que vem sendo realizado. Primeiramente o número especial da revista World Development (2001, v. 29, n.3), que trata exclusivamente do debate sobre as atividades não-agrícolas na América Latina, oferecen- 
do um amplo espectro de trabalhos que indicam que o fenômeno da combinação de ocupações agrícolas e não-agrícolas é disseminado por vários países da região, tanto naqueles que possuem uma agropecuária mais modernizada como Brasil, Chile e México ou aqueles nos quais a incorporação do padrão técnico-produtivo da revolução verde alcançou proporções menos intensivas como Peru, Honduras e El Salvador. O segundo trabalho importante a reconhecer o papel das atividades não-agrícolas no desenvolvimento das economias rurais é o livro organizado por Ruben G. Echeverría (2001), responsável pelo Departamento de Desenvolvimento Sustentável de um importante organismo internacional, o Banco Interamericano de Desenvolvimento (BID). Nesse trabalho, em artigo introdutório, Janvry e Sadoulet (2001,p.9) afirmam que "é impossível compreender a pobreza rural sem considerar o elemento extra-agrícola e especialmente os componentes não-agrícolas das rendas dos domicílios [...] a conclusão é que o combate a pobreza deve abarcar as múltiplas fontes de ingresso do habitante rural pobre". Nesse sentido, ambas as publicações, além adicionar legitimidade acadêmica e política a um tema que já é estudado há mais tempo por cientistas sociais, buscam vinculá-lo a um aspecto crucial da realidade rural dos vários países daAmérica Latina, que se refere ao problema da pobreza e da exclusão social no campo.

Segundo Berdegué, Reardon e Escobar (2001,p.184) o emprego rural nãoagrícola é atualmente responsável por cerca de $40 \%$ das rendas dos habitantes rurais da América Latina e há uma clara tendência que aponta para seu crescimento na região. Segundo esses autores, a importância das atividades rurais nãoagrícolas está no fato de que elas podem integrar soluções para três grandes problemas do mundo rural latino-americano - a pobreza rural, a transformação do setor agropecuário e a modernização técnico-produtiva. Estudo recente da CEPAL (2000) indicou que as rendas de atividades não-agrícolas assumem um caráter extremamente importante para as populações rurais mais pobres, muitas vezes significando a única renda monetária para essas famílias. No que concerne à transformação do setor agropecuária e à sua modernização produtiva, as atividades nãoagrícolas tendem a representar uma oportunidade de emprego complementar, pois à medida que houver maior apropriação de tecnologias pela agricultura tende $\mathrm{a}$ crescer o aumento de ocupações nos serviços ligados ao agroprocessamento e beneficiamento de produtos.

Nesta seção pretende-se averiguar em que medida a generalização das atividades não-agrícolas no espaço rural também ocorre nos países latino-americanos. Em relação ao continente como um todo, as informações são bastante escassas, limitando-se basicamente aos trabalhos produzidos por pesquisadores ligados à CEPAL (Klein, 1992; Weller, 1997; Dirven, 1997, 1998).

Tal como nos países desenvolvidos, na América Latina a população rural é cada vez menos sinônimo de população agrícola, e as formas de ocupação do espaço rural são cada vez mais diversificadas. Segundo Klein, desde 1950 a 
população latino-americana vem crescendo a uma taxa média de 2,6\% ao ano e a população rural não cresceu mais que $0,7 \%$ no mesmo período. Em $1950,54 \%$ dos trabalhadores da América Latina estavam ocupados na agricultura, mas em 1992 eram apenas 25\% do total. Em trabalho mais recente, Dirven (1997,p. 19) mostra que a participação da PEA agrícola no conjunto da PEA rural, na maioria dos países latino-americanos, é inferior a 70\%. Segundo a autora, nos próximos anos, as projeções indicam que o emprego na agricultura tende a reduzir-se ainda mais em relação à PEA total da região (o que significa em torno de 40 milhões de pessoas), mesmo sem afetar os índices de produtividade e o volume da produção agrícola total. Ao mesmo tempo, no entanto, esse progresso técnico tenderá a ser seletivo e beneficiar uma parcela pequena dos agricultores da região, fazendo com que muitos tenham de abandonar o meio rural e outros tantos precisem aceitar uma remuneração cada vez menor para seu trabalho, o que pode implicar o aumento da pobreza rural, que já atinge cerca $60 \%$ da população latino-americana que vive da agricultura (Dirven, 1997).

Os dados da Tabela 8, extraídos de estatísticas da FAO e sistematizadas por Dirven (1997), mostram que a queda da PEA agrícola deve intensificar-se ainda mais a partir do ano 2000 , em todos os países da região.

Tabela 8

PAÍSES SELECIONADOS DAAMÉRICALATINA: PROJEÇÃO

DAPOPULAÇÃO ECONOMICAMENTEATIVA(PEA) NAAGRICUUTURA, 1990-2010.

\begin{tabular}{|c|c|c|c|c|c|c|c|c|c|c|c|}
\hline \multirow[b]{2}{*}{ PAÍSES } & \multicolumn{3}{|c|}{ PEA agrícola (\%) } & \multicolumn{4}{|c|}{ PEA agrícola (1.000) } & \multicolumn{4}{|c|}{$\begin{array}{c}\text { Crescimento anual PEA } \\
\text { agrícola }(\%)\end{array}$} \\
\hline & 0 & 1990 & J & 1 & & & & $\begin{array}{c}1980 \\
- \\
1990\end{array}$ & $\begin{array}{c}1990 \\
- \\
1995\end{array}$ & $\begin{array}{c}1990 \\
- \\
2000\end{array}$ & $\begin{array}{c}2000 \\
- \\
2010\end{array}$ \\
\hline Amé & & & & 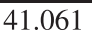 & & & & 0,5 & 4 & 1 & $-0,3$ \\
\hline & 10 & & & & & & & 1,2 & & & $-1,1$ \\
\hline & 41,6 & 46 & $J$ & & & & & 1,6 & & & 1,4 \\
\hline & 24,3 & 23 & 13,6 & 13.366 & 13. & 12. & 11 & $-0,3$ & $-2,4$ & $-0,7$ & $-1,1$ \\
\hline & 12 & 18 & & 58 & & & & $-0,3$ & 0,5 & $-1,1$ & $-1,4$ \\
\hline & 27,3 & 26 , & 16,0 & 2.885 & 3.5 & 2.83 & 5 & 0,6 & 0,6 & 0,2 & $-0,9$ \\
\hline & 30,3 & 33 , & 16 , & 996 & 10 & & & 0,6 & 0,3 & 0,0 & $-0,7$ \\
\hline & 30,0 & 27, & 18,9 & 9.340 & 8.885 & 9.705 & 9.39 & 1,1 & 0,2 & 0,4 & $-0,3$ \\
\hline & 46,3 & 39 & 41,0 & 67 & & & 1.000 & 2,7 & 0,8 & 2,1 & 1,9 \\
\hline & 34,7 & 35 , & 24 & 2.443 & 2.863 & 2.694 & 2.842 & 1,3 & 1,5 & 1,0 & 0,5 \\
\hline & 13,5 & 14,2 & 10,2 & 162 & 19 & 15 & 145 & $-0,9$ & 0,2 & $-0,5$ & $-0,6$ \\
\hline Venez & 1,0 & 12,0 & 4,9 & 52 & 936 & 673 & 572 & $-0,5$ & 1,4 & $-1,1$ & $-1,6$ \\
\hline
\end{tabular}

Fonte: Dirven (1997, p.77). 
No entanto, essa redução da população ocupada em atividades agrícolas não significa que haja uma retomada do êxodo rural iniciado na década de 1960. No período recente, especialmente a partir dos anos oitenta, a queda do emprego agrícola tem sido compensada parcialmente pelo crescimento da população rural ocupada em atividades não-agrícolas. Isso é o que mostra o trabalho de Klein (1992), que além de reconhecer que as migrações rural-urbanas influenciaram a queda da PEA agrícola, indica que essa redução também pode ser atribuída às mudanças recentes das novas formas de ocupação do meio rural.

Segundo o mesmo autor, existe uma tendência de crescimento da população economicamente ativa ocupada em ramos de atividades não-agrícolas na América Latina, conforme mostram os dados da Tabela 9. Ele salienta que, na região, a PEA agrícola vem crescendo a uma taxa anual negativa de $0,8 \%$, nos anos referidos, ao passo que a proporção de pessoas ocupadas em atividades não-agrícolas aumenta a uma taxa positiva de 3,4\%, no mesmo período, que é inclusive superior ao crescimento da média total da PEA latino-americana, que foi de $2,6 \%$. No conjunto da região, a PEA rural não-agrícola passou de $23,9 \%$ para $29,1 \%$, registrando um crescimento de $5 \%$ nos anos recentes. Vale a pena notar que mesmo nos países de grande extensão territorial, como o Brasil, o México e, em menor escala, a Colômbia, registra-se um crescimento bem mais favorável da PEA não-agrícola em relação à PEA ocupada na agricultura, o que demonstra que as atividades rurais não-agrícolas não se constituem em fenômeno singular de um país específico.

\section{Tabela 9}

PAÍSES SELECIONADOS DA AMÉRICA LATINA: TAXAS ANUAIS (\%) DE CRESCIMENTO DA POPULAÇÃO ECONOMICAMENTE ATIVA (PEA), SEGUNDO LOCAL DE DOMICÍLIO E RAMO DE ATIVIDADE.

\begin{tabular}{|l|c|c|c|c|c|}
\hline \multirow{2}{*}{\multicolumn{1}{c|}{ PAÍSES }} & \multirow{2}{*}{$\begin{array}{c}\text { PEA } \\
\text { TOTAL }\end{array}$} & \multirow{2}{*}{ PEA } & \multicolumn{2}{c|}{ PEA RURAL } & Período da \\
\cline { 4 - 5 } & & URANA & Agrícola & Não-agrícola & $\begin{array}{c}\text { Nariação } \\
\text { anual }^{\mathbf{1}}\end{array}$ \\
\hline América Latina & 2,6 & 4,1 & $-0,8$ & 3,4 & - \\
Bolívia & 2,6 & 3,9 & 1,8 & 1,0 & $1976-88$ \\
Brasil & 3,9 & 6,2 & $-1,0$ & 5,2 & $1970-80$ \\
Chile & 2,6 & 3,4 & $-0,2$ & 0,0 & $1970-82$ \\
Colômbia & 1,7 & 3,7 & $-3,0$ & 4,9 & $1964-73$ \\
México & 2,5 & 3,1 & 0,8 & 4,1 & $1970-80$ \\
Paraguai & 3,6 & 5,1 & 1,8 & 4,5 & $1972-82$ \\
Peru & 3,5 & 4,3 & 2,1 & 2,1 & $1972-81$ \\
Uruguai & 1,4 & 2,0 & $-0,8$ & $-2,4$ & $1975-85$ \\
Venezuela & 4,2 & 5,2 & $-1,1$ & 2,3 & $1971-81$ \\
\hline
\end{tabular}

${ }^{1}$ Refere-se ao ano base dos dados apresentados.

Fonte: Klein (1992, p. 6), com base em censos nacionais de população de cada país. 
Para Klein, existem três hipóteses para explicar a evolução das atividades rurais não-agrícolas na América Latina. A primeira, sustenta o autor, está relacionada à distribuição geográfica e demográfica da população em um território que pode variar de um país para outro. A segunda hipótese é de que o processo de modernização tecnológica da agricultura acabou forjando o crescimento dos serviços auxiliares às atividades agrícolas, o que tem criado um novo mercado de trabalho no espaço rural diferente do agrícola, embora a ele vinculado. Por último, Klein acredita que, em conseqüência deste processo de ampliação do mercado de trabalho agrícola e não-agrícola, surgem novas atividades no meio rural, em geral ligadas à prestação de serviços, como as comunicações e o serviço público em geral.

Entre as características da evolução das atividades não-agrícolas no espaço rural, o autor destaca o crescimento das atividades comerciais e dos serviços. Segundo Klein, isso indica que a estrutura do emprego rural nãoagrícola está se tornando bastante similar ao mercado de trabalho urbano. Essa homogeneidade do emprego rural e urbano não-agrícola por ramos de atividade sugere uma integração entre o próprio mercado de trabalho. A Tabela 10 apresenta o crescimento de alguns dos principais ramos de atividade da população economicamente ativa rural, com destaque para os serviços, o comércio, a construção e as indústrias manufatureiras, bem como o desempenho do próprio ramo agrícola. Este último, não obstante ainda ocupar ao redor de $70 \%$ da PEA rural, mostra-se em declínio em quase todos os países do continente.

Além da homogeneização do mercado de trabalho, Klein (1992, p.1011) também destaca que há pelo menos outras duas conseqüências importantes decorrentes das transformações estruturais do emprego e das formas de ocupação no espaço rural. A primeira refere-se ao crescimento das unidades produtivas ocupadas em tempo parcial na agricultura, muitas vezes executando mais de uma atividade produtiva em setores diferentes. Esse fenômeno relaciona-se tanto à capacidade de absorção do progresso técnico nas propriedades como ao aumento da ociosidade de parte da força de trabalho dos membros da família, fazendo com que os trabalhos temporários ou acessórios exteriores à propriedade constituam-se em novas fontes de rendimento. A segunda consequiência está relacionada às transformações estruturais da economia capitalista contemporânea, especificamente no que tange aos processos de descentralização da produção urbano-industrial para áreas rurais ou periurbanas. Esses processos obedecem à necessidade crescente de flexibilização das relações de trabalho e redução dos custos de mãode-obra, que em geral são bem mais atraentes nas áreas rurais. A emergência do trabalho a domicílio e o deslocamento de empresas para áreas rurais da América Latina inserem-se nesse contexto. 
Tabela 10

AMÉRICALATINA. PRINCIPAIS RAMOS DE ATIVIDADE DA POPULAÇÃO ECONOMICAMENTEATIVA(PEA)COM DOMICÍLIORURAL(EM \%)

\begin{tabular}{|c|c|c|c|c|c|c|c|c|}
\hline $\begin{array}{l}\text { Paíse } \\
\text { Ramo }\end{array}$ & 岂 & 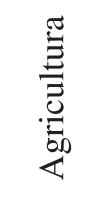 & 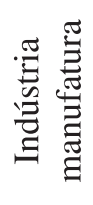 & 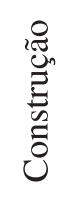 & $\begin{array}{l}.0 \\
0 \\
0 \\
0 \\
0 \\
0\end{array}$ & 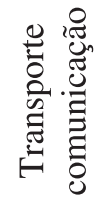 & 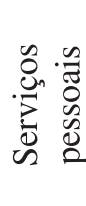 & 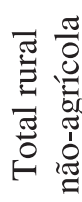 \\
\hline Bolívi & & & & 6 & & 1,5 & 2 & 25, \\
\hline \multirow[b]{2}{*}{ Brasil } & & & & & & & $\frac{7}{0}$ & \\
\hline & & 8 & &, 5 & 2, & 1, & ,2 & o, \\
\hline \multirow{2}{*}{ Chi } & U & 70,7 & 5, & 2,9 & 2 , & 1 , & 6,2 & 29 \\
\hline & & 71, & $4, ?$ & 2,5 & 2 , & 1, & 10,8 & 28 \\
\hline \multirow{2}{*}{ Colôi } & 64 & 81,1 & 3, & 1,2 & 1 , & 0 , & 3,4 & 18,9 \\
\hline & 198 & 71, & 6 & 1,7 & 8, & 2 , & 7,3 & 28 , \\
\hline \multirow{2}{*}{ Méxic } & 70 & 81,0 & 6,4 & 2,0 & 2 , & 0 , & 5,6 & 19 \\
\hline & & 7 & - & 3,9 & 4,0 & 1 & 7,3 & 24 \\
\hline \multirow{2}{*}{ Parag } & 72 & 79, & 9 & 1,5 & 2 , & 0 , & 5,2 & 20 , \\
\hline & & & 8 & 3,2 & 2, & 1 & 5,1 & 24 \\
\hline \multirow{2}{*}{ Urugu } & 75 & 67,2 & 7 & 3,1 & 3 , & 1 , & 10,8 & 32,8 \\
\hline & & 7 & 7 & 2,7 & 2 & 1, & 10,3 & 28 \\
\hline \multirow{2}{*}{ Venezuela } & 1971 & 63,50 & 4, & 2,5 & 5 , & 1,6 & 9,5 & 36,5 \\
\hline & 1981 & & 5,0 & 5,8 & 7, & 3,0 & 11,5 & 45 \\
\hline & & 76,1 & 5, & 2,5 & 3, & 1,3 & 6,8 & 23,9 \\
\hline & & 70,9 & 6,5 & 3,3 & 5,1 & 1,6 & 8,4 & 29,1 \\
\hline
\end{tabular}

${ }^{1}$ Média simples de todos os países.

Fonte: Klein (1992, p. 5) a partir dos censos nacionais de população.

Ainda de acordo com Klein, o desenvolvimento das atividades rurais nãoagrícolas na América Latina decorre do próprio crescimento da agricultura. Por essa razão, sugere que as ações de desenvolvimento integrado atuem de forma a compatibilizar as políticas agrícolas com outras formas de geração de emprego no meio rural, especialmente através da descentralização industrial. Para ele, a emergência das atividades rurais não-agrícolas na América Latina pode ter um papel importante no alívio à pobreza rural e ao estímulo de novas atividades econômicas no espaço rural ${ }^{58}$ Como razões que justificariam políticas de apoio a esse tipo de desenvolvimento, o autor destaca a importância das rendas rurais não-agrícolas

\footnotetext{
${ }^{58}$ Em 1990, 61\% da população rural da América Latina encontrava-se em condição de pobreza (Klein, 1992, p.12).
} 
para a dinamização da economia local e para a diversificação das fontes de rendas dos agricultores, oferecendo-se alternativas de inserção profissional para os mais jovens que não desejam dedicar-se a essa atividade (Klein, 1992).

Nessa mesma direção, Weller (1997) também identificou a agricultura como o setor responsável pela expansão dos empregos rurais não-agrícolas na região do istmo centro-americano (Costa Rica, Honduras, Panamá e Guatemala). Segundo esse autor, as características da agropecuária constituem fatores determinantes dos empregos não-agrícolas, podendose identificar três dinâmicas que dela derivam diretamente e outras duas não se vinculam a ela. A primeira, que em geral está diretamente ligada ao processo produtivo agrícola, como as atividades complementares ou acessórias; a segunda deriva dos empregos não-agrícolas gerados pelas demandas de consumo da própria população rural (como bens e serviços, transportes e comércio) e a última estaria relacionada à disponibilidade de excedentes de mão-de-obra, em face do nível de emprego agrícola existente (mão-de-obra essa que migra para as zonas urbanas e permanece ocupada em atividades que o autor chama de "refúgio"). Além desses fatores, Weller também aponta o artesanato rural típico e o turismo rural como exemplos de atividades que também podem contribuir para a geração de empregos não-agrícolas no meio rural e, finalmente, atividades que derivam da expansão dos serviços públicos em infra-estrutura, decorrentes de investimentos do Estado, que se constituiriam, portanto, na quinta dinâmica identificada pelo autor na América Central.

\subsection{AS OCUPAÇÕES AGRÍCOLAS E NÃO-AGRÍCOLAS NO BRASIL: O PROJETO RURBANO}

No Brasil, a emergência das atividades não-agrícolas no meio rural desperta o interesse de diversos estudiosos, sendo tal fenômeno apontado por alguns como a provável face do "novo rural brasileiro". Segundo Graziano da Silva (1999), a novidade consiste no fato de que o meio rural já não pode mais ser associado apenas à produção agrícola e pecuária. O aparecimento de novas atividades estaria introduzindo um conjunto de novas funções no espaço rural, especialmente aquelas ligadas às ocupações não-agrícolas da população. O ator social privilegiado dessa nova caracterização do rural seria o aparecimento das famílias pluriativas, que combinam vários tipos de atividades e ocupações em uma mesma unidade familiar ou estabelecimento, fazendo com que os seus membros possuam vários tipos de inserção profissional. ${ }^{59}$

\footnotetext{
${ }^{59}$ Segundo Graziano da Silva (1999, p. X), “[...] Em resumo, deixam de ser trabalhadores agrícolas especializados para se converterem em trabalhadores (empregados ou conta própria) que combinam formas diversas de ocupação (assalariados ou não), em distintos ramos de atividades (agrícolas e não-agrícolas)".
} 
Entre os fatores que contribuíram para a emergência dessa situação, os pesquisadores ligados ao Projeto Rurbano, coordenado pelo professor José Graziano da Silva, têm apontado três causas principais. Primeiramente, a emergência das atividades não-agrícolas e da pluriatividade, segundo Graziano da Silva et al. (1996), seria decorrente do que chama de "urbanização do campo", um processo resultante de um transbordamento das cidades e do mercado de trabalho urbano para as áreas rurais situadas em seu entorno, como é o caso da região de Campinas, no Estado de São Paulo. Nessas áreas, o processo de urbanização do campo se daria através da expansão de novas atividades que pouco ou nada têm a ver com a produção agropecuária stricto sensu. Trata-se de novos tipos de ocupações, ligadas ao lazer e ao ócio (os pesque-pague e chácaras de recreio seriam o seu melhor exemplo), as moradias secundárias da classe média urbana, áreas de preservação destinadas ao ecoturismo (parques e estações ecológicas, sobretudo) e novas formas de emprego como os jardineiros, pedreiros, motoristas, especialmente atividades ligadas à prestação de serviços (Graziano da Silva, 1997).

A segunda razão explicativa decorre da crise do próprio setor agrícola, particularmente a partir das dificuldades enfrentadas pelo setor agroexportador instaladas no início da década de 1990. Para Graziano da Silva (1999), essa crise estaria associada às transformações estruturais da agricultura brasileira, provocadas pela modernização tecnológica e um conjunto de condicionantes macroeconômicos típicos da década de 1990, como as mudanças no financiamento da produção, na política de abertura comercial, no acirramento da concorrência com os produtos estrangeiros e, especialmente, na sobrevalorização cambial da moeda brasileira ocorrida entre 1994 e 1998. Como efeitos desses condicionantes assistiu-se à queda da rentabilidade dos principais produtos da agropecuária brasileira que, segundo Lopes (1996), reduziram-se, em média, 40\% na comparação do período 1981-1985 com o qüinqüênio 1991-1995. Essa diminuição da renda também se refletiu na redução dos valores dos principais ativos agrícolas, especialmente os preços pagos pela terra. A queda dos preços não apenas afastou os interessados em obter lucro com o "negócio agrícola" como diminuiu, rapidamente, as rendas gerais na agricultura brasileira.

Em trabalho recente, Graziano e Del Grossi (1999) mostraram que, na década 1990, especialmente no período pós-Plano Real, houve uma acentuada queda das rendas agrícolas, especialmente entre as categorias dos ocupados rurais por conta própria, em que estão inseridos os agricultores familiares. Os autores mostraram que entre 1992 e 1999 houve uma redução das rendas agrícolas das pessoas ocupadas e com domicílio em áreas rurais vis-à-vis aquelas obtidas em atividades não-agrícolas. No ano de 1999, os autores verificaram que a renda média das pessoas domiciliadas no rural e ocupadas em atividades agrícolas somente foi maior do que do ramo de serviços. 
Finalmente, a terceira causa que explicaria o surgimento das atividades rurais não-agrícolas está relacionada aos limites de crescimento do próprio emprego agrícola, que estaria ocorrendo devido à alta taxa de ociosidade tecnológica e ao subemprego existente na agricultura brasileira. Uma simulação, a partir da base de dados da Fundação Seade (de São Paulo), demonstrou que caso houvesse uma disseminação dos sistemas de produção mais modernos de cada produto, como é atualmente praticado em determinadas regiões do Estado de São Paulo, estendendo-se para todas as áreas cultivadas desse produto, haveria uma redução de $45 \%$ na demanda por força de trabalho agrícola, no nível de Brasil, e de $23 \%$ para São Paulo (Graziano da Silva, 1999, p. 89). Além disso, em estudo recente, Kageyama (1997, p.7) estimou, com base nos dados das PNADs de 1992 e 1995, que haveria $35,3 \%$ de pessoas subocupadas em atividades agrícolas no Brasil (sendo 34\% na região Sul) que poderiam ser consideradas subempregadas, definindo-se essa situação como aquela pessoa ocupada menos de 15 horas por semana e cujo rendimento é inferior ao valor de um salário mínimo.

Para se ter uma idéia da importância desse processo, apresenta-se na sequiência algumas tabelas que trazem informação sobre o emprego e a ocupação nas atividades rurais não-agrícolas na região Sul do Brasil. A Tabela 11 apresenta informações sobre a População Economicamente Ativa (PEA) ocupada em atividades agrícolas e não-agrícolas com domicílio rural e urbano para o Brasil, para a região Sul e nos estados do Rio Grande do Sul e Santa Catarina. A fonte desses dados são a Pesquisa Nacional por Amostra de Domicílios (PNADs), realizada pelo IBGE, reprocessados pelo projeto Rurbano. 


\section{Tabela 11}

BRASIL,REGIÃO SUL, RIO GRANDE DO SULE SANTACATARINA. POPULAÇÃO ECONOMICAMENTEATIVA(PEA) OCUPADA, SEGUNDO O SETOR DE ATIVIDADE E A SITUAÇÃO DO DOMICÍLIO, 1981 E 1999 (1.000 PESSOAS)

\begin{tabular}{|c|c|c|c|c|c|c|c|c|c|}
\hline & \multicolumn{3}{|c|}{ AGRÍCOLA } & \multicolumn{3}{|c|}{ NÃO-AGRÍCOLA } & \multicolumn{3}{|c|}{ TOTAL } \\
\hline Brasil & Rural & Urbano & Total & Rural & Urbano & Total & Rural & Urbano & Total \\
\hline 1981 & $.735,9$ & 563,9 & 1 & 60,8 & & 6 & $13.796,7$ & 31. & 65,4 \\
\hline 1992 & $.192,5$ & $3.668,6$ & $14.861,1$ & $3.496,7$ & $42.878,1$ & & 9,2 & 5,7 & $51.235,9$ \\
\hline 1999 & $0.230,5$ & $3.437,5$ & 13.6 & $4.620,0$ & $49.327,4$ & 4 & & $52 .^{\circ}$ & $67.615,5$ \\
\hline (\% a.a $81 / 4$ & $0,4 * * *$ & $3,3 * * *$ & 1,0 & $1,2 * * *$ & $3,6^{* * *}$ & $3,4 * * *$ & 0,6 & $3,6^{* * *}$ & 2,7 \\
\hline$\left(\%\right.$ a.a $\left.92 / 99^{b}\right)$ & $-1,7$ * & $-1,6^{* * *}$ & $-1,7$ & $3,7 * * *$ & $2,0^{* * *}$ & & 0 & & $1,3 * * *$ \\
\hline \multicolumn{10}{|l|}{ Região Sul ${ }^{1}$} \\
\hline & & 431,1 & & 610,4 & 7 & 4.9 & & 4.7 & $8.426,5$ \\
\hline & & 53 & & 9,1 & & & & 4,0 & $10.632,6$ \\
\hline 1999 & $1.969,0$ & 456,2 & $2.425,2$ & 847,9 & $7.977,3$ & $8.825,2$ & $2.817,0$ & $8.433,6$ & $11.250,6$ \\
\hline$\left(\%\right.$ a.a $\left.81 / 92^{\mathrm{a}}\right)$ & $-1,5 * * *$ & $2,0 * * *$ & $-1,0 * * *$ & 0,4 & $4,3 * * *$ & $3,9 * * *$ & $-1,2 * * *$ & 4,1 & $2,1 * * *$ \\
\hline$\left(\%\right.$ a.a $\left.92 / 99^{b}\right)$ & $-3,9 * * *$ & $-2,9 * * *$ & $-3,7 * * *$ & $4,3 * * *$ & $2,1 * * *$ & $2,3 * * *$ & 0,1 & $1,8 * * *$ & $0,8 * * *$ \\
\hline \multicolumn{10}{|l|}{ Rio Grande Sul } \\
\hline 1981 & $1.160,8$ & 112,3 & 1.2 & 276,5 & & $2.360,4$ & & 2. & $3.633,5$ \\
\hline 1992 & 964,0 & 183,9 & $1.147,9$ & 297,1 & 1,5 & $3.378,6$ & & 3.2 & 4.526 \\
\hline 1999 & 789,3 & 150,7 & 940,0 & 352,3 & $3.367,3$ & $3.719,7$ & 1,7 & $3.518,0$ & $4.659,8$ \\
\hline$\left(\%\right.$ a.a $\left.81 / 92^{\mathrm{a}}\right)$ & $-1,7 * * *$ & $4,6 * * *$ & $-0,9$ & 0,7 & $3,6^{* * * *}$ & 3,3 & $-1,2$ & 3,7 & 2,0 \\
\hline$\left(\%\right.$ a.a $\left.92 / 99^{b}\right)$ & $-2,6 * * *$ & $-3,5 * * *$ & $-2,7 * * *$ & $2,7 * * *$ & 1,3 & $1,5 * * *$ & 1 , & $1,1 * * *$ & $0,5 * * *$ \\
\hline \multicolumn{10}{|l|}{ Santa Catarina } \\
\hline & & 63 & & & & & & 7 & 1.560 \\
\hline 19 & 629,1 & 97,8 & 726,9 & 179,7 & $.290,3$ & $1.470,0$ & 808,8 & $1.388,1$ & $2.196,9$ \\
\hline 1999 & 465,8 & 82,5 & 548,3 & 245,4 & $1.607,0$ & $1.852,4$ & 711,3 & $1.689,6$ & $2.400,9$ \\
\hline$\left(\%\right.$ a.a $\left.81 / 92^{\mathrm{a}}\right)$ & 0,4 & $4,0 * * *$ & 0,8 & 0,5 & $5,4 * * *$ & 4,6 & 0,4 & 5,3 & 3,2 \\
\hline$\left(\%\right.$ a.a $\left.92 / 99^{b}\right)$ & $-4,4 * * *$ & $-3,0$ & $-4,2 * * *$ & $4,1 * * *$ & $3,1 * * *$ & $3,2 * * *$ & $-2,1 * * *$ & $2,8 * * *$ & $1,1 * * *$ \\
\hline
\end{tabular}

a Teste $t$ indica se a diferença entre os dois anos é significativa ou não.

${ }^{\mathrm{b}}$ Estimativa do coeficiente de uma regressão log-linear contra o tempo. Neste caso, o teste t indica a existência ou não de uma tendência nos dados.

$(* * *),(* *)$ e $(*)$ indicam valores significativos ao nível de 5,10 e $20 \%$, respectivamente.

Fonte: Núcleo de Economia Agrícola do IE/Unicamp, Projeto Rurbano (Tabulações Especiais).

Consultando-se as taxas anuais de crescimento dos dois períodos analisados, percebe-se que nos anos da década de 1990, em todas as quatro unidades de análise selecionadas, houve uma redução da população domiciliada no meio rural e ocupada em atividades agrícolas. Em Santa Catarina, essa redução chegou a ser de 4,4\% a.a. entre 1992 e 1999. Não obstante, aparentemente compensando essa perda de postos de trabalho agrícola, em todas as quatro unidades também se registrou um aumento da população com domicílio rural ocupada em atividades não-agrícolas, cabendo outra vez o destaque para Santa Catarina, onde o aumento foi de $4,1 \%$ a.a.

Além das três razões antes mencionadas, os autores insistem em afirmar que uma das razões fundamentais que provocaria essas transformações no mercado de trabalho rural brasileiro seria o processo de aprofun- 
damento da modernização técnico-produtiva da agricultura no período recente (Graziano da Silva, 1999; Kageyama, 1997). O entendimento é de que o progresso tecnológico e a integração crescente dos processos produtivos agropecuários com os diferentes setores da economia acabam alterando o perfil dos produtores agrícolas e estimulando o aparecimento de novas demandas no espaço rural, muitas delas sem nenhum tipo de ligação com a produção agrícola. É claro que caracterizar o meio rural brasileiro como um espaço não exclusivamente agrícola não implica, em contrapartida, afirmar que o significado econômico, social e produtivo da agricultura tenha perdido sua importância.

Indubitavelmente, há também outras razões apontadas como responsáveis pela emergência das atividades não-agrícolas no meio rural brasileiro. Uma delas refere-se ao processo de descentralização e interiorização de determinados tipos de indústrias, especialmente de bens de consumo não-duráveis, como têxteis, vestuário e calçados, em algumas regiões do Sul do Brasil (especialmente no Rio Grande do Sul e em Santa Catarina) e, mais recentemente, no nordeste, que têm contribuído para revitalização econômica de determinadas áreas rurais (Schneider, 1999).

De um modo geral, esses estudos indicam estar em curso um processo de alteração das características do mercado de trabalho rural e da ocupação da força de trabalho residente nessas áreas, aliada a uma rápida diminuição das pessoas ocupadas em atividades agrícolas. Entre os ramos de atividades que mais têm atraído os trabalhadores no meio rural do Brasil e da região Sul estão: a prestação de serviços, a indústria da transformação e da construção, seguidos do comércio de mercadorias, transporte e comunicação e o ramo social, conforme mostra a Tabela 12, dividida em valores absolutos e relativos. Em termos relativos, o destaque positivo fica por conta do ramo de serviços auxiliares, que cresceu a uma taxa média anual de 14\% entre 1992 e 1999 tanto na região Sul como no Brasil. Não obstante este crescimento destacado, não se pode deixar de destacar as taxas relativas de crescimento do ramo da prestação de serviços, que é mais estável nas duas décadas, além dos ramos de transporte e comunicação, comércio de mercadorias e administração pública.

Entre os setores de atividades não-agrícolas que mais cresceram no meio rural brasileiro no período recente destaca-se a indústria da construção civil e o emprego doméstico. Tanto no conjunto da região Sul como no Brasil, o setor da indústria da construção cresceu $9,5 \%$ a.a.e $8,2 \%$ a.a, respectivamente, e o emprego doméstico cresceu a uma taxa de cerca de 5\% a.a. entre 1992 e 1999, conforme mostra a Tabela 13, a seguir. Outro setor cujo crescimento 
merece destaque é o da indústria de alimentos, que entre 1992 e 1999 revelou um acréscimo de $16,4 \%$ a.a. no conjunto da região Sul assim como o de restaurantes, que cresceu 6,9\% a.a. no Brasil.

Tabela 13

BRASILE REGIÃO SUL.PRINCIPAIS SETORES DEATIVIDADES

NÃO-AGRÍCOLAS DAPOPULAÇÃO RURALOCUPADA, 1981 A 1999

(1.000 PESSOAS)

\begin{tabular}{|l|l|l|l|l|}
\hline \multirow{2}{*}{\multicolumn{1}{c|}{\begin{tabular}{c} 
Setor de atividade \\
\multicolumn{1}{c|}{ não-agrícola }
\end{tabular}}} & \multicolumn{3}{c|}{ Taxa de crescimento (\% a.a.) } \\
\cline { 2 - 5 } & \multicolumn{2}{|c|}{ Região Sul } & \multicolumn{2}{c|}{ Brasil } \\
\cline { 2 - 5 } & $1981 / 92^{\mathrm{a}}$ & $1992 / 99$ & $1981 / 92^{\mathrm{a}}$ & $1992 / 99 \mathrm{~b}$ \\
\hline Emprego doméstico & $2,7 * *$ & $5,2 * * *$ & $4,9 * * *$ & $4,8 * * *$ \\
Construção civil & $-2,4 *$ & $9,5 * * *$ & $-7,5 * * *$ & $8,2 * *$ \\
Estab. ensino público & $-0,3$ & $-3,4 * * *$ & $4,3 * * *$ & 0,7 \\
Comércio alimentos & $-1,6$ & 1,0 & $2,2 * * *$ & $1,6 *$ \\
Restaurantes & $-3,4 *$ & 5,2 & $7,2 * * *$ & $6,9 * * *$ \\
Indústria alimentos & $-1,9$ & $11,9 * * *$ & $5,3 * * *$ & 0,5 \\
Indústria transformação 60 & 1,8 & $-0,2$ & 0,9 & $-1,2$ \\
Administração municipal & $-3,2 *$ & $9,6 * * *$ & $10,1 * * *$ & $4,9 *$ \\
Alfaiataria & $6,7 * * *$ & 0,2 & $-0,5$ & $-3,4 * * *$ \\
Comércio ambulante & $16,6 * * *$ & - & $7,9 * * *$ & $7,5 * * *$ \\
Indústria de madeiras & $-4,6 * * *$ & $2,3 *$ & $-3,0 * * *$ & $-1,2$ \\
Transporte de carga & $-3,1 *$ & 3,1 & $2,0 *$ & $2,6 * *$ \\
Assist. técnica - veículos & 0,3 & - & $5,8 * * *$ & $5,3 * * *$ \\
Total & $-0,3$ & $4,3 * * *$ & $0,9 * * *$ & $3,7 * * *$ \\
\hline PEA NÃO-AGRÍCOLA & 0,4 & $4,3 * * *$ & $1,2 * * *$ & $3,7 * * *$ \\
\hline
\end{tabular}

a Teste $t$ indica se a diferença entre os dois anos é significativa ou não.

${ }^{\mathrm{b}}$ Estimativa do coeficiente de uma regressão log-linear contra o tempo. Neste caso, o teste t indica a existência ou não de uma tendência nos dados.

$(*),(* *),(* * *)$ significam respectivamente $20 \%, 10 \%$ e $5 \%$.

Fonte: Tabulações Especiais do Projeto Rurbano, NEA-IE/Unicamp, janeiro 1999.

Os efeitos das transformações na formas de ocupação da força de trabalho na agricultura brasileira, em especial da região Sul, ficam mais evidentes quando se analisa o comportamento das diferentes categorias sociais que compõem a estrutura produtiva da agropecuária. Uma consulta à

\footnotetext{
${ }^{60} \mathrm{Não}$ confundir o ramo da indústria da transformação com o setor de mesmo nome. O ramo da indústria da transformação englobla o setor de mesmo nome.
} 
Tabela 12a

REGIÃO SUL E BRASIL. RAMOS DE ATIVIDADES NÃO-AGRÍCOLAS DA PEA OCUPADA RESIDENTE EM DOMICÍLIOS RURAIS, 1992 A 1999 (1.000 PESSOAS)

\begin{tabular}{|l|r|r|r|r|r|r|}
\hline RAMOS DE & \multicolumn{3}{|c|}{ REGIÃO SUL } & \multicolumn{3}{c|}{ BRASIL } \\
\cline { 2 - 7 } ATIVIDADES & 1981 & 1992 & 1999 & 1981 & 1992 & 1999 \\
\hline Indústria da transformação & 172,6 & 195,9 & 251,1 & 646,4 & 772,9 & 809,4 \\
Indústria da construção & 64,6 & 49,6 & 86,5 & 734,6 & 312,0 & 631,4 \\
Outras atividades & 35,8 & 23,0 & 18,9 & 126,4 & 114,6 & 115,0 \\
industriais & 61,9 & 78,2 & 93,8 & 313,3 & 452,2 & 578,6 \\
Comércio de mercadorias & 119,1 & 157,7 & 200,0 & 618,1 & 975,0 & $1.276,6$ \\
Prestação de serviços & 11,8 & 11,0 & 26,4 & 55,0 & 55,3 & 121,6 \\
Serviços auxiliares & 30,3 & 22,3 & 40,3 & 116,6 & 145,9 & 199,4 \\
atividades econômicas & 78,7 & 70,4 & 79,3 & 309,4 & 468,9 & 587,9 \\
Transporte e comunicação & 25,1 & 26,2 & 42,0 & 95,8 & 162,2 & 239,3 \\
Social & 10,4 & 4,9 & 9,6 & 45,2 & 37,7 & 60,9 \\
Administração pública & 610,4 & 639,1 & 847,9 & $3.060,8$ & $3.496,7$ & $4.620,1$ \\
Outras atividades & \multicolumn{5}{|c}{} \\
\hline \multicolumn{1}{|c|}{ TOTAL } & \multicolumn{5}{|c|}{} \\
\hline
\end{tabular}

Tabela 12b

REGIÃO SUL E BRASIL. TAXAS DE CRESCIMENTO DOS RAMOS DE ATIVIDADES NÃO-AGRÍCOLAS DA PEA OCUPADA RESIDENTE EM DOMICÍLIOS RURAIS, 1992 A 1999.

\begin{tabular}{|c|c|c|c|c|}
\hline \multirow{2}{*}{$\begin{array}{l}\text { RAMOS DE } \\
\text { ATIVIDADES }\end{array}$} & \multicolumn{2}{|c|}{ REGIÃO SUL } & \multicolumn{2}{|c|}{ BRASIL } \\
\hline & $1981 / 92^{\mathrm{a}}$ & $1992 / 99^{b}$ & $1981 / 92^{\mathrm{a}}$ & $1992 / 99^{b}$ \\
\hline Indústria da transformação & 1,2 & $3,3 * * *$ & $1,6 * * *$ & 0,4 \\
\hline Indústria da construção & $-2,4 *$ & $9,5 * * *$ & $-7,5 * * *$ & $8,2 * *$ \\
\hline $\begin{array}{l}\text { Outras atividades } \\
\text { industriais }\end{array}$ & $-3,9 * * *$ & $-1,5$ & $-0,9$ & 0,6 \\
\hline Comércio de mercadorias & $2,1 *$ & 2,4 & $3,4 * * *$ & $4,1 * * *$ \\
\hline Prestação de serviços & $2,6 * * *$ & $4,7 * * *$ & $4,2 * * *$ & $3,9 * * *$ \\
\hline $\begin{array}{l}\text { Serviços auxiliares } \\
\text { atividades econômicas }\end{array}$ & $-0,6$ & 14,0 & 0,0 & $13,6 * * *$ \\
\hline Transporte e comunicação & $-2,8 *$ & $6,1 * * *$ & $2,1 * * *$ & $5,8 * * *$ \\
\hline Social & $-1,0$ & $1,5 *$ & $3,9 * * *$ & $2,5 * * *$ \\
\hline Administração pública & 0,4 & $6,5 * * *$ & $4,9 * * *$ & $3,7 * *$ \\
\hline Outras atividades & $-6,6 * * *$ & $10,8 * * *$ & $-1,6$ & $7,7 * * *$ \\
\hline TOTAL & 0,4 & $4,3 * * *$ & $1,2 * * *$ & $3,7 * * *$ \\
\hline
\end{tabular}

${ }^{a}$ Teste $t$ indica se a diferença entre os dois anos é significativa ou não.

${ }^{\mathrm{b}}$ Estimativa do coeficiente de uma regressão log-linear contra o tempo. Neste caso, o teste t indica a existência ou não de uma tendência nos dados.

$(* * *),(* *)$ e $(*)$ indicam valores significativos ao nível de 5,10 e $20 \%$, respectivamente.

Fonte: Núcleo de Economia Agrícola do IE/Unicamp, Projeto Rurbano (Tabulações Especiais). 
Tabela 14 permite identificar, com notável clarividência, o desempenho negativo de todas as categorias de ocupação em atividades agrícolas. Entre 1992 e 1999, todas as categorias ocupadas na agricultura registraram taxas negativas de crescimento, resultando em um decréscimo de 3,9\% a.a. no conjunto dos três estados da região sul e de 1,7\% a.a. no Brasil como um todo. O destaque entre as quatro categorias listadas fica para a categoria dos "conta própria" na região Sul, que diminuíram a uma taxa de $2,7 \%$ a.a. e os ocupados como empregadores no Brasil, que caíram a uma taxa de 3,9\% a.a. entre 1992 e 1999. Outra categoria que registrou uma queda significativa, no mesmo período, foi a dos que se declararam não-remunerados, como usualmente o fazem os demais membros das unidades familiares como as esposas e crianças, entre outros, que no Sul reduziram-se em $-5,4 \%$ a.a. e, no Brasil, em -2,6\% ao ano entre 1992 e 1999.

Tabela 14

BRASIL EREGIÃOSUL.TAXAS DE CRESCIMENTO DA POPULAÇÃO ECONOMICAMENTEATIVARURALOCUPADA(PEA) SEGUNDOA POSIÇÃO NAOCUPAÇÃO, 1981-1999 (1.000 PESSOAS)

\begin{tabular}{|l|r|r|r|r|}
\hline \multirow{2}{*}{ Posição na ocupação } & \multicolumn{2}{|c|}{ Região Sul } & \multicolumn{2}{c|}{ Brasil } \\
\cline { 2 - 5 } & $1981 / 92^{\mathrm{a}}$ & $1992 / 99^{\mathrm{b}}$ & $1981 / 92^{\mathrm{a}}$ & $1992 / 99^{\mathrm{b}}$ \\
\hline Ativ. Agrícolas & $-1,5 * * *$ & $-3,9 * * *$ & $0,4 * * *$ & $-1,7 * * *$ \\
Empregados & $-1,9 * * *$ & $-1,5 *$ & $-0,7 * * *$ & $-1,8 * * *$ \\
Conta própria & $-1,2 * * *$ & $-2,7 * * *$ & 0,3 & $-0,5$ \\
Empregadores & $-1,4$ & $-5,6$ & $1,2 * *$ & $-3,9 * * *$ \\
Não-remunerados & $-1,6 * * *$ & $-5,4 * * *$ & $1,3 * * *$ & $-2,6 * * *$ \\
\hdashline Ativ. Não-agrícolas & 0,4 & $4,3 * * *$ & $1,2 * * *$ & $3,7 * * *$ \\
Empregados & 0,5 & $4,1 * * *$ & $0,5 * *$ & $4,1 * * *$ \\
Conta própria & 0,5 & $4,5 * * *$ & $2,3 * * *$ & $2,7 * * *$ \\
Empregadores & $-1,7$ & $12,9 * * *$ & $4,2 * * *$ & $9,9 * * *$ \\
Não-remunerados & $-0,9$ & 1,4 & $6,4 * * *$ & 0,7 \\
\hline Total & $-1,2 * * *$ & $-2,2 * * *$ & $0,6 * * *$ & $-0,4$ \\
\hline
\end{tabular}

${ }^{a}$ Teste $t$ indica se a diferença entre os dois anos é significativa ou não.

${ }^{\mathrm{b}}$ Estimativa do coeficiente de uma regressão log-linear contra o tempo. Neste caso, o teste t indica a existência ou não de uma tendência nos dados.

$(*),(* *),(* * *)$ significam respectivamente $20 \%, 10 \%$ e $5 \%$.

Fonte: Tabulações Especiais do Projeto Rurbano, NEA-IE/Unicamp, janeiro 1999. 
Em contraste com a redução do número de pessoas economicamente ativas ocupadas nas atividades agrícolas, as categorias que estavam trabalhando em ocupações não-agrícolas registraram um comportamento muito distinto. Em primeiro lugar, tal como indicado na Tabela 14, deve-se destacar que nas taxas de crescimento anuais referentes às atividades nãoagrícolas não há sinal negativo no caso brasileiro e para a região no período entre 1992 e 1999, nem mesmo quando os testes estatísticos não são significativos. Outra informação importante refere-se ao crescimento da categoria dos empregadores em atividades não-agrícolas com domicílio rural, que alcança a surpreendente taxa de 12,9\% a.a. na região Sul e aumento de 9,9\% a.a. no Brasil, no período compreendido entre 1992 e 1999. Além disso, tomando-se apenas a região Sul, verifica-se um aumento igualmente significativo nas atividades não-agrícolas das categorias nas quais estão os agricultores familiares, que são as pessoas que declaram estar ocupadas por conta própria (4,5\% a.a.). Mas é igualmente significativo o aumento de 4,1\% a.a. dos empregadores em atividades não-agrícolas.

Frente à queda generalizada do emprego agrícola nos diferentes países e regiões, pode-se afirmar que o crescimento das atividades não-agrícolas no meio rural está se configurando como um fenômeno absolutamente relevante não apenas para promover o desenvolvimento econômico e o bem-estar social das populações rurais, mas, também, para a própria interpretação analítica das transformações agrárias contemporâneas. Em outro capítulo será retomada a análise das ocupações agrícolas e não-agrícolas, dedicando-se especial atenção ao seu desempenho recente nos Estados de Santa Catarina e do Rio Grande do Sul. 


\section{CAPÍTULO4 \\ Pluriatividade e agricultura familiar no sul do Brasil: Rio Grande do Sul e Santa Catarina em perspectiva comparada}

As transformações gerais verificadas nas formas de ocupação e emprego do meio rural, analisadas no capítulo anterior, já são amplamente difundidas na estrutura agrária dos dois estados meridionais do Brasil. A partir da década de 1980, algumas regiões dos estados do Rio Grande do Sul e Santa Catarina passam a registrar processos sociais de alteração das formas usuais de ocupação da força de trabalho no meio rural (Schneider, 1999; Raud, 1999). Em ambos os casos, algumas áreas colonizadas por imigrantes de origem alemã vindos diretamente da Alemanha (por isso chamadas de áreas de colonização antiga ou velha), como a região do Vale do Sinos no Rio Grande do Sul e do Vale do Itajaí em Santa Catarina, passaram a viabilizar novas estratégias de reprodução social dos agricultores familiares nelas instalados.

Nesse sentido, parece importante a tentativa de demonstrar que as mudanças ocupacionais da força de trabalho rural que se verificam nos países desenvolvidos, discutidas anteriormente, também estão presentes na estrutura agrária do sul do Brasil. Assim, as duas seções que se seguem a esta introdução serão dedicadas à discussão das transformações nas formas de ocupação em atividades agrícolas e não-agrícolas nos dois estados meridionais da Federação. Na terceira seção apresenta-se algumas características gerais sobre o processo de articulação entre a agricultura familiar e o mercado de trabalho industrial (que é composto pela indústria coureiro-calçadista no caso gaúcho e têxtil no caso catarinense) que se constituiu nas regiões antes mencionadas. Na quarta e última seção são apresentadas algumas considerações sobre os dois estudos de caso realizados para analisar situações concretas de famílias rurais que recorrem a estratégia da pluriatividade.

Antes de passar para apresentação dos dados secundários é necessário fazer alguns esclarecimentos sobre a base de informações utilizada nas duas próximas seções. As informações sobre a dinâmica das atividades agrícolas e não-agrícolas nos estados do Rio Grande do Sul e Santa Catarina são resul- 
tantes de tabulações especiais produzidas pelo Projeto Rurbano, utilizando como fonte a Pesquisa Nacional de Amostra por Domicílios, do IBGE (doravante denominada simplesmente de PNAD). A PNAD é uma pesquisa por amostras baseada no último censo demográfico disponível. Em cada Estado é feito um corte, separando áreas urbanas, rurais e metropolitanas, motivo pelo qual os dados não podem ser desagregados por microrregiões homogêneas.

Também é importante ressaltar que os dados divulgados pelo IBGE, a partir de 1992, não podem ser comparados com aqueles que foram levantados antes dessa data, porque a partir desse ano a metodologia de levantamento foi modificada, tanto no que se refere à cobertura temática como, principalmente, em relação ao conceito de "trabalho". ${ }^{61}$ O IBGE passou a considerar como "ocupadas" as pessoas de 10 anos ou mais de idade que realizavam algum trabalho (remunerado ou não) durante pelo menos uma hora, na semana de referência (período de coleta das informações), visando captar determinados grupos de pessoas envolvidos em atividades econômicas que anteriormente não eram incluídas, abandonando o critério anterior que considerava ocupadas as pessoas que se envolviam em atividades durante pelo menos quinze horas de trabalho (Graziano da Silva e Del Grossi, 1997). Criou-se, dessa forma, a noção de "trabalho ampliado", decorrente do que Del Grossi (1999) chamou de "acréscimo conceitual". Segundo esse autor, essa modificação, de fato, introduziu uma distorção na PNAD, pois ampliou-se o universo de pessoas consideradas como ocupadas quando, segundo seus cálculos, essas pessoas, na verdade, trabalhavam em atividades de auto-construção ou para o auto-consumo. Em princípio, essa diferença impediria a comparação das PNADs dos anos noventa com a de 1981, obstáculo que foi superado estatisticamente pela equipe do Projeto Rurbano, que ao final conseguiu compatibilizar as séries em apreço, analisadas a seguir.

\subsection{ADINÂMICADAS ATIVIDADES AGRÍCOLAS E NÃO-AGRÍCOLAS NO RIO GRANDE DO SUL}

Nas últimas três décadas, a agricultura gaúcha, como de resto a dos demais Estados meridionais do Brasil, conheceu um desenvolvimento econômico sem precedentes em sua história. Esse desenvolvimento, tal como

\footnotetext{
${ }^{61}$ Além disso, a partir da nova classificação da posição na ocupação, que passou a ser adotada, suprimiu-se a subdivisão dos trabalhadores volantes, com ou sem intermediário, e definiram-se duas outras categorias decorrentes da ampliação do conceito de trabalho (trabalhadores na produção para o próprio consumo e trabalhadores na construção para o próprio uso). Para maiores detalhes acerca das consequiências metodológicas dessa mudança, consultar Del Grossi (1999) e Botelho (1999).
} 
ocorreu na maior parte dos países desenvolvidos, caracterizou-se sobretudo pelo incremento de novas tecnologias, pela utilização em larga escala de insumos e máquinas industriais e pelas alterações biogenéticas mediante a introdução de variedades de plantas e animais de alto rendimento. Como resultado, obteve-se um extraordinário crescimento da produtividade agrícola, fazendo com que o Brasil e, especialmente, a região Sul, lograssem uma inserção privilegiada no comércio mundial de commodities agrícolas (Goodman e Redclift, 1989). Esses são os traços mais gerais do conjunto de mudanças que os estudiosos chamam de "modernização da agricultura" (Graziano da Silva, 1996).

No caso do Rio Grande do Sul, esse intenso processo de transformação estrutural pode ser dividido em três fases distintas, quanto ao desenvolvimento agrário. O primeiro desses períodos, como já apontado em outro trabalho (Schneider e Navarro, 2000), promoveu a "euforia" da modernização produtiva, iniciada na década de 1970, quando os governos militares empreenderam uma inédita transformação de algumas regiões agrárias brasileiras (em especial no centro-sul), retirando-as de seu atraso tecnológico e inserindo-as em circuitos propriamente capitalistas - o que permitiu não apenas a constituição de novas estruturas de produção, mas também o desenvolvimento de uma nova racionalidade de gestão agrícola.

Esgotada essa primeira fase de mudanças, simbolizada pelo ano de 1981, quando foram modificadas as normas financeiras do primeiro período, particularmente no que se refere ao esgotamento da política de crédito rural facilitado, os anos seguintes foram marcados por uma dinâmica inteiramente nova da agricultura. A década de 1980 representou, de fato, um outro período inteiramente singular, com as evidências de um ajuste macroeconômico persistente e, como resultado, uma deterioração dos aparatos institucionais ligados ao mundo rural, além da incapacidade financeira crescente do Estado em manter mecanismos de estímulo e/ou sustentação da agricultura similares ao período anterior, em especial aqueles relacionados aos reclamos de financiamento da produção nas condições antes estabelecidas (Graziano da Silva, 1996; Delgado, 1995).

A década de 1990, por sua vez, introduziu outros contornos econômicos e políticos, identificando uma terceira e diferente fase do desenvolvimento agrário do Rio Grande do Sul. Nesses anos mais recentes, com o forte recuo das políticas públicas para o meio rural, modificou-se ainda mais o ambiente social e produtivo, não apenas desafiando os estudiosos e suas ferramentas analíticas mas, principalmente, materializando novos desafios e impasses que têm confrontado os próprios produtores, provavelmente em magnitude sem precedentes.

Os efeitos sociais resultantes dessas mudanças mais gerais variaram de região para região agrária brasileira mas, salienta-se, geralmente observou-se uma 
forte modificação demográfica no meio rural, com a diminuição constante do número da famílias dedicadas às atividades propriamente agrícolas, o que repercutiu sobre a estrutura de ocupação do mercado de trabalho rural.

Considerando-se o conjunto da população gaúcha com idade acima de 10 anos, percebe-se que aquelas pessoas que possuem domicílio rural demonstram, tendencialmente, uma trajetória inversa àquelas que residem no espaço urbano, em relação à sua expressão numérica. Os dados das Tabelas 1a e 1b ressaltam a expressiva diminuição da população rural em idade ativa (PIArural), no período 1981/1999, registrando uma redução absoluta de 459 mil pessoas. Importante também salientar que essa redução foi mais significativa na década de 1980 (ou seja, comparando-se as PNADs de 1981 e 1992) do que na década de 1990 (comparando-se as PNADs de 1992 e até 1999). Isso implica dizer que no início dos anos oitenta havia mais gente em idade ativa apta ao trabalho no meio rural gaúcho do que em 1992. No primeiro caso, a diminuição anual, conforme mostra a Tabela $1 \mathrm{~b}$, alcançou a taxa de $2,0 \%$ a.a., enquanto que na década de 1990 a redução sofreu teve uma queda significativa, registrando uma taxa negativa de apenas 0,2\% a.a. entre 1992 e 1999.

Tabela 1a

RIOGRANDE DO SULE BRASIL.POPULAÇÃO EM IDADEATIVA(PIA) COM 10 ANOS OU MAIS, OCUPADAE NÃO-OCUPADA, SEGUNDO O LOCALDEDOMICÍLIO EO SETOR DEATIVIDADE, 1981-1999 (1.000 PESSOAS)

\begin{tabular}{|l|l|c|c|c|c|c|c|}
\hline \multicolumn{2}{|c|}{} & \multicolumn{2}{c|}{1981} & \multicolumn{2}{c|}{1992} & \multicolumn{2}{c|}{1999} \\
\cline { 3 - 9 } \multicolumn{2}{|c|}{} & RS & BR & RS & BR & RS & BR \\
\hline Urbana & $4.180,6$ & $64.669,1$ & $5.733,5$ & $89.510,7$ & $6.508,2$ & $104.693,5$ \\
\hline Rural & $2.119,0$ & $24.233,8$ & $1.706,0$ & $23.784,5$ & $1.660,6$ & $25.402,2$ \\
\hline $\begin{array}{l}\text { PEA } \\
\text { rural } \\
\text { ocupada }\end{array}$ & Agrícola & $1.160,8$ & $10.735,9$ & 964,0 & $11.192,5$ & 789,3 & $10.230,5$ \\
\cline { 2 - 9 } & Não-agrícola & 276,5 & $3.060,8$ & 297,1 & $3.496,7$ & 352,3 & $4.620,0$ \\
\hline $\begin{array}{l}\text { PEA } \\
\text { rural } \\
\text { não- } \\
\text { ocupada }\end{array}$ & $\begin{array}{l}\text { Não- } \\
\text { ocupados ou } \\
\text { procurando } \\
\text { emprego }\end{array}$ & 6,8 & 139,4 & 11,2 & 312,0 & 29,8 & 594,6 \\
\cline { 2 - 9 } & Aposentados & 128,1 & $1.240,0$ & 110,2 & $1.517,1$ & 172,3 & $2.235,8$ \\
\cline { 2 - 9 } & Outros & 546,8 & $9.057,8$ & 323,4 & $7.266,1$ & 316,7 & $7.721,3$ \\
\hline
\end{tabular}




\section{Tabela 1b}

RIO GRANDEDO SULE BRASIL.TAXAS DECRESCIMENTO

DA POPULAÇÃO EM IDADE ATIVA (PIA) COM 10 ANOS OU MAIS,

OCUPADA E NÃO-OCUPADA, SEGUNDO O LOCAL DE DOMICÍLIO

E O SETOR DE ATIVIDADE, 1981-1999 (1.000 PESSOAS)

\begin{tabular}{|l|l|c|c|c|c|}
\hline \multirow{2}{*}{ Taxas de crescimento (\% a.a.) } & \multicolumn{2}{c|}{$1981 / 92^{\mathrm{a}}$} & \multicolumn{2}{c|}{$1992 / 99^{\mathrm{b}}$} \\
\cline { 3 - 6 } & $\mathrm{RS}$ & $\mathrm{BR}$ & $\mathrm{RS}$ & $\mathrm{BR}$ \\
\hline Urbana & $2,9^{* * *}$ & $3,0^{* * *}$ & $1,9^{* * *}$ & $2,3^{* * *}$ \\
\hline Rural & $-2,0^{* * *}$ & $-0,2^{*}$ & $-0,2$ & $0,9^{* * *}$ \\
\hline $\begin{array}{l}\text { PEA rural } \\
\text { ocupada }\end{array}$ & Agrícola & $-1,7^{* * *}$ & $0,4^{* * *}$ & $-2,6^{* * *}$ & $-1,7^{* * *}$ \\
\cline { 2 - 6 } & Não-agrícola & 0,7 & $1,2^{* * *}$ & $2,7^{* * *}$ & $3,7^{* * *}$ \\
\hline \multirow{3}{*}{$\begin{array}{l}\text { PEA rural } \\
\text { não-ocupada }\end{array}$} & $\begin{array}{l}\text { Não-ocupados ou } \\
\text { procurando emprego }\end{array}$ & $4,7^{*}$ & $7,6^{* * *}$ & $17,8^{* * *}$ & $10,8^{* * *}$ \\
\cline { 2 - 6 } & Aposentados & $-1,4$ & $1,9^{* * *}$ & $5,1^{* * *}$ & $5,7^{* * *}$ \\
\cline { 2 - 6 } & Outros & $-4,7^{* * *}$ & $-2,0^{* * *}$ & 0,6 & $1,4^{* * *}$ \\
\hline
\end{tabular}

a Teste $t$ indica se a diferença entre os dois anos é significativa ou não.

${ }^{\mathrm{b}}$ Estimativa do coeficiente de uma regressão log-linear contra o tempo. Neste caso, o teste $t$ indica a existência ou não de uma tendência nos dados.

$(* * *),(* *),(*)$ significam respectivamente $5 \%, 10 \%$ e $20 \%$.

Fonte: Núcleo de Economia Agrícola do IE/Unicamp, Projeto Rurbano (Tabulações Especiais).

Essa variação da população em idade ativa deve-se, sobretudo à redução da PEA ocupada em atividades agrícolas e não-agrícolas, uma vez que não se registra uma queda expressiva no número de indivíduos não economicamente ativos. ${ }^{62}$ Embora os dados não permitam o cálculo dos saldos migratórios, indicam que o meio rural gaúcho ainda continua perdendo população, podendo-se afirmar que o êxodo da população para as cidades ainda persiste, embora tenha diminuído significativamente nos anos noventa, quando comparado com a década anterior (Schneider e Radomsky, 2002).

Ao analisar, retrospectivamente, as principais mudanças demográficas e ocupacionais desde a década de 1980 pode-se associar a diminuição absoluta da população rural aos impactos da intensa modernização tecnológica e produtiva da década de 1970, que se desenvolveu em quase todas as regiões rurais do Rio Grande do Sul e em alguns outros estados do Brasil. Embora esse processo tenha diminuído sua intensidade com o esgotamento dos mecanismos financeiros que lhe deram origem, ainda assim nos anos mais recentes seguiu seu itinerário transformador, concentrando-se em algumas áreas e em algumas atividades produtivas. O processo de modernização implicou, no Rio Grande do Sul, a visível redução de postos de trabalho, com a eliminação das

\footnotetext{
${ }^{62}$ A população economicamente ativa teve taxas de crescimento negativas nos anos oitenta e nos noventa (-1,1\% e -1,2\% respectivamente) ao passo que a população não economicamente ativa teve queda apenas nos anos oitenta (Schneider e Radomsky, 2002).
} 
formas transitórias de trabalho antes vigentes, como o pequeno arrendamento, a parceria e o trabalho de agregados nas propriedades maiores antes dedicadas principalmente (como atividade propriamente comercial) à triticultura, posteriormente o mesmo acontecendo na principal zona de produção da soja, o chamado Planalto Médio. Nessa região, o boom da soja deslocou rapidamente os pequenos produtores rurais, não apenas pela lenta constituição de uma nova racionalidade na gestão da propriedade mas, igualmente, pela expansão da mecanização, eliminando postos de trabalho antes existentes. ${ }^{63}$ Para a crescente população que perdeu suas formas de ocupação em função da expansão da soja, o retorno às suas regiões de origem, normalmente o Alto Uruguai (região fronteiriça com Santa Catarina) não era mais possível, pela pressão demográfica existente nessa última região, pela estrutura fundiária marcada predominantemente por pequenos estabelecimentos e, em especial, pela inexistência de "terras livres" ou de custo de aquisição mais baixo, que pudessem ser ocupadas.

Nesse contexto, a migração para as cidades tornou-se quase a única alternativa existente, particularmente em direção ao Vale dos Sinos, região próxima a Porto Alegre, tendo como centro irradiador a cidade de Novo Hamburgo, que, na década de 1980, tornou-se um dos principais centros produtores de calçados (principalmente femininos) do país, setor fortemente exportador (Schneider, 1994, 1999). Os movimentos migratórios, contudo, nos anos mais recentes, não podem ser comparados com aqueles da década de 1980, pois o crescimento da economia gaúcha reduziu-se e freou decisões migratórias. No auge da modernização da agricultura gaúcha, nos anos setenta, os movimentos populacionais foram intensos, quando a população residente em regiões rurais reduziu-se em 15\% em apenas dez anos, situação que não mais se repetiria nos anos seguintes, em face da citada perda de dinamismo da economia do Estado (seguindo um padrão nacional).

Já na década de 1990, como antes referido, há outros fatores novos a considerar, particularmente os efeitos da abertura comercial e seus impactos em alguns setores produtivos da economia agrícola do Estado (Navarro, 1996). Em especial, devem ser salientados dois setores que, talvez, mais te-

\footnotetext{
${ }^{63} \mathrm{O}$ domínio da soja no Estado, a partir dos anos setenta, e seus impactos em todas as esferas da vida rural gaúcha, não pode ser menosprezado, com o cultivo passando, aos poucos, não apenas a orientar as decisões produtivas mas, igualmente, por seu papel na constituição dos complexos agroindustriais. A substituição dos espaços de produção, com a profunda modificação na área plantada, é também notável, bastando lembrar que, no final da década de 1960, a soja apresentava diminuta participação nas estatísticas de produção agrícola no Estado mas, em 1980, já ocupava 47\% da área plantada. Enquanto isso, lavouras como o milho, feijão e mandioca, que antes ocupavam, no primeiro período citado, respectivamente, $42,5 \% ; 6,3 \% \mathrm{e}$ $6,7 \%$, passaram a ocupar, em 1980 , apenas $21,2 \% ; 2,2 \%$ e $2,1 \%$, respectivamente.
} 
nham contribuído para a redução das oportunidades de ocupação no meio rural gaúcho. Em primeiro lugar a orizicultura, que experimentou anos problemáticos, situações de endividamento ainda não resolvidos, descapitalização devido à queda dos preços das terras e do arroz, concorrência com produtos importados, entre outros aspectos - em muitos casos, levando à redução da área plantada e à desativação de postos de trabalho. $\mathrm{O}$ segundo setor produtivo que, provavelmente, tenha sido mais afetado pela abertura comercial e o acordo do Mercosul, foi o de produção de leite. Nesse caso, realizado por milhares de pequenos produtores, com baixíssima produtividade geral e inteiramente despreparados para concorrer com os produtos de origem argentina ou uruguaia. Ainda não são conhecidos os impactos reais desse processo no Rio Grande do Sul, mas evidências assistemáticas indicam uma permanente sangria populacional, em decorrência do abandono de uma atividade que, quase sempre, desempenha um papel fundamental para esses produtores, pela possibilidade de produção de renda permanentemente ao longo do ano.

Essas transformações na economia gaúcha, e no meio rural em particular, tornam-se ainda mais evidentes quando se compara apenas a população rural economicamente ativa ocupada em atividades agrícolas e não-agrícolas. Registra-se claramente, nesse exame, a queda mais do que proporcional dos ocupados em atividades agrícolas, inclusive com uma taxa de redução anual que acelera-se na década de 1990 - isto é, enquanto nos anos oitenta a redução anual foi de 1,7\% a.a., o esvaziamento ocupacional na década seguinte aumentou para 2,6\% a.a. Cabe notar, contudo, que a redução da PEA foi mais acentuada entre os ocupados em atividades agrícolas, que em 1981 somavam 1.160.800, em 1992 esse número baixou para 964.000 e, em 1999, chegou a 789.379 , muito embora a participação relativa no período tenha-se mantido em torno de $70 \%$.

O Gráfico 1 evidencia mais claramente essa redução da população rural ocupada em atividades agrícolas vis-à-vis à população ocupada em atividades não-agrícolas, mostrando, entre essas últimas, a relativa estabilidade numérica ao longo do tempo, somados todos os sub-ramos das formas de ocupação não-agrícolas. Não fosse o papel dessas atividades, a queda relativa da população rural economicamente ativa poderia ter sido ainda mais drástica. 


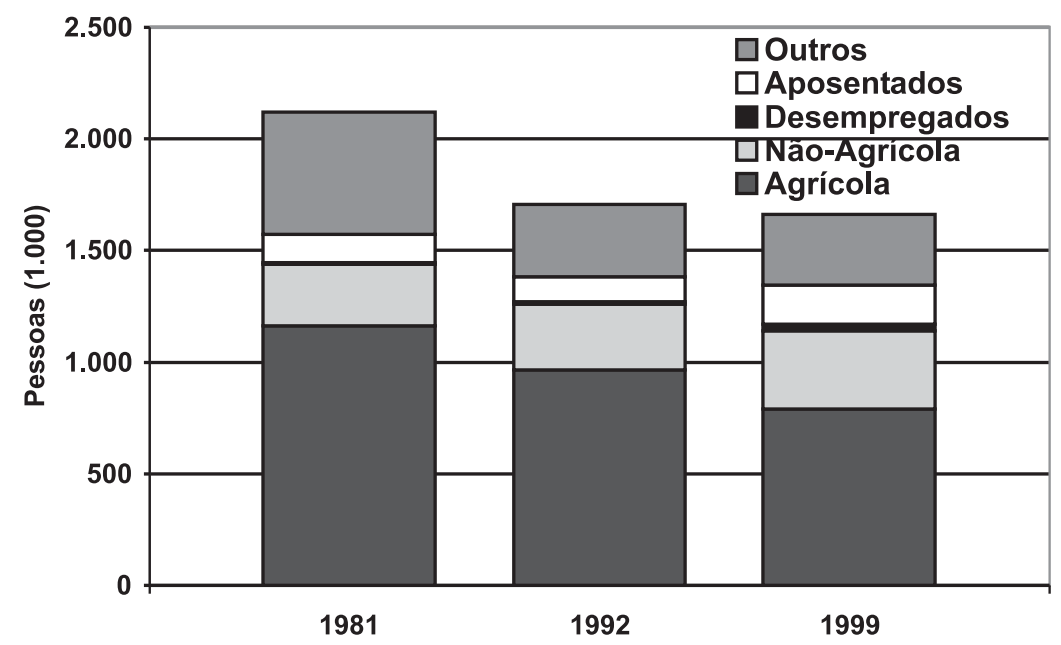

Gráfico 1. Rio Grande do Sul. PEA rural ocupada em atividades agrícolas e não-agrícolas, PEA rural procurando emprego (desempregados), aposentados e outros - 1981-1999

Fonte: Projeto Rurbano. Tabulações Especiais das PNADs.

Os dados apresentados no gráfico apontam algumas das mudanças da estrutura ocupacional do mundo rural gaúcho, que parecem indicar a lenta formação de postos de trabalho e variadas formas de ocupação que não são estritamente agrícolas, mas situadas em ambientes definidos como rurais. Adiferença, em face do ocorrido em outros estados - particularmente, São Paulo - é a velocidade desse processo de mudanças, muito menos acentuado no Rio Grande do Sul. Tal fato não deve surpreender, em vista da melhor estruturação de suas regiões agrárias, em sentido amplo, onde ainda prevalecem valores socioculturais e iniciativas produtivas que afirmam a pequena propriedade colonial, assim servindo como "freio" ao abandono da atividade. ${ }^{64}$

Por outro ângulo, a análise anterior acerca do emprego rural, em suas variantes agrícola e não-agrícola, pode revelar caminhos novos para o desenvolvimento rural e para políticas tendentes a rejuvenescer os ambientes agrários do Estado. Ou seja, verifica-se uma lenta mudança em comunidades rurais que apresentam dinâmicas econômicas locais nas quais as oportunidades de ocupação em atividades não-agrícolas são cada vez mais impor-

\footnotetext{
${ }^{64}$ No Rio Grande do Sul, ao contrário do Brasil, a queda da PEA rural ocupada nas atividades agrícolas já era expressiva nos anos oitenta. Também diferente é o desempenho das atividades não-agrícolas da PEA rural, que no Estado não chegou a ser significativa nos anos noventa, mas, no Brasil, revelou um crescimento de 3,7\% a.a. (Campanhola e Graziano da Silva, 2000).
} 
tantes. Nessas áreas, gradualmente se constrói uma rede de relações econômicas e comerciais que potencializam oportunidades de ampliar empreendimentos e iniciativas para os moradores e produtores do local, não dependendo mais exclusivamente da produção agrícola e dos humores dos mercados de venda de produtos de origem agropecuária, com preços que, na presente década, tenderam à queda, reduzindo ou limitando as chances de geração de renda ao longo do tempo.

\section{Tabela 2}

RIO GRANDE DO SUL. RAMOS DE ATIVIDADES NÃO-AGRÍCOLAS DAPEA OCUPADADE 10 ANOS OU MAIS RESIDENTEEM DOMICÍLIOS RURAIS, 19921999(1.000 PESSOAS)

\begin{tabular}{|l|c|c|c|c|c|}
\hline \multirow{2}{*}{ RAMOS DE ATIVIDADES } & \multicolumn{2}{|c|}{$\begin{array}{c}\text { Rio Grande } \\
\text { do Sul }\end{array}$} & \multicolumn{2}{c|}{$\begin{array}{c}\text { Taxas de } \\
\text { crescimento } \\
(\% \text { a.a. })\end{array}$} \\
\cline { 2 - 7 } & 1981 & 1992 & 1999 & $1981 / 92^{\mathrm{a}}$ & $1992 / 99^{\mathrm{b}}$ \\
\hline Indústria da transformação & 62,6 & 85,7 & 104,8 & $2,9 * *$ & 1,7 \\
Indústria da construção & 31,5 & 22,1 & 32,7 & $-3,2 *$ & $8,2 * * *$ \\
Outras atividades industriais & 23,9 & 15,7 & 11,8 & $-3,8 *$ & $-3,3$ \\
Comércio de mercadorias & 29,5 & 31,4 & 40,6 & 0,6 & $2,6 *$ \\
Prestação de serviços & 62,1 & 77,5 & 79,3 & 2,0 & $2,0 *$ \\
Serviços auxiliares atividades & 4,0 & 3,1 & 10,3 & $-2,4$ & 16, \\
econômicas & 13,5 & 8,6 & 16,8 & $-4,0 *$ & $7,2 * * *$ \\
Transporte e comunicação & 32,5 & 33,2 & 31,1 & 0,2 & 0,8 \\
Ramo social & 11,6 & 16,0 & 18,7 & 3,0 & 1,0 \\
Administração pública & 5,3 & 3,8 & 6,2 & $-3,0$ & $9,3 *$ \\
Outras atividades & 276,5 & 297,1 & 352,4 & 0,7 & $2,7 * * *$ \\
\hline Total da PEA Não-agrícola & \multicolumn{5}{|c|}{} \\
\hline
\end{tabular}

${ }^{a}$ Teste $\mathrm{t}$ indica se a diferença entre os dois anos é significativa ou não.

${ }^{\mathrm{b}}$ Estimativa do coeficiente de uma regressão log-linear contra o tempo. Neste caso, o teste t indica a existência ou não de uma tendência nos dados.

$(* * *),(* *),(*)$ significam respectivamente $5 \%, 10 \%$ e $20 \%$.

Fonte: Núcleo de Economia Agrícola do IE/Unicamp, Projeto Rurbano (Tabulações Especiais).

Em relação aos principais ramos das atividades não-agrícolas da população economicamente ativa, é preciso notar que nos anos oitenta a parcela da população rural envolvida no ramo da indústria de transformação cresceu 2,9\% a.a., mantendo uma participação ao redor de 7,7\% do total da PEA rural ocupada em atividades não-agrícolas. Em geral, esse ramo é composto pelas pequenas unidades semi-industriais processadoras de produtos agropecuários, como as agroindústrias avícolas e suinocultoras e também os laticínios de pequeno porte. Desta- 
ca-se também o ramo da prestação de serviços, que aumentou sua capacidade ocupacional em mais de 17 mil postos entre 1981 e 1999, chegando a crescer a uma taxa de $2 \%$ a.a. entre 1992-1999, o que indica, talvez, a maior diversidade de atividades nos ambientes rurais, não necessariamente relacionadas ao setor agrícola propriamente dito. Juntos, os ramos da indústria de transformação e da prestação de serviços somavam, em 1999, 184 mil pessoas, o que representa mais de $50 \%$ da PEA ocupada em atividades não-agrícolas (ver total da PEA rural ocupada na Tabela 3).

Na década de 1990, a exceção em relação ao comportamento dos ramos das atividades não-agrícolas da PEA rural ocupada ocorreu, de fato, no ramo dos serviços auxiliares de atividades econômicas, que cresceu $16,8 \%$ a.a., e no ramo dos transportes e da comunicação, aumentando em $7,2 \%$ a.a., inclusive invertendo a tendência negativa verificada na década anterior. Esse desempenho parece indicar que atualmente as atividades econômicas que mais crescem no espaço rural gaúcho são aquelas associadas ao setor de serviços, quer sejam pessoais ou outros. Em razão disso, não é difícil compreender por que as pessoas que estão domiciliadas no meio rural buscam de forma crescente mecanismos para aproximar-se do padrão de vida urbano. Nesse sentido, os transportes e os veículos de comunicação vêm desempenhando um papel muito significativo.

O crescimento destacado dos ramos dos serviços auxiliares das atividades econômicas e dos transportes e comunicações na PEA rural não-agrícola do Rio Grande do Sul, entre 1992 e 1999, também pode estar relacionado ao que Weller (1997) chamou de novas dinâmicas econômicas do meio rural, em sua análise sobre os países do istmo centro-americano. Graziano da Silva e Del Grossi (1997, p. 16) buscaram relacionar a realidade agrária brasileira com as proposições de Weller e concluíram que, no Brasil, não apenas podem ser encontradas as cinco dinâmicas destacadas pelo autor como acrescentaram mais algumas outras. Para esses autores, os ramos anteriormente referidos inserem-se em um tipo de "dinâmica econômica" particular, aquela identificada com as "atividades derivadas do consumo final da população rural", que se referem a bens e serviços não-agropecuários, tanto de origem rural como urbana.

Além das informações sobre as atividades e os ramos que mais vêm crescendo no espaço rural gaúcho, é possível avançar na comparação entre as ocupações nas atividades agrícolas e não-agrícolas também no seu conjunto, focalizando-as pelas posições usuais que se encontram no meio rural, que são os empregados, os empregadores, os ocupados por conta própria (o que significa que não contratam trabalhadores assalariados e são eles mesmos que exercem suas atividades na propriedade ou fora dela) e os não-remunerados. 
Tabela 3

RIO GRANDEDO SUL.EVOLUÇÃODAPEARURALOCUPADA SEGUNDOA POSIÇÃO NA OCUPAÇÃO, EM 1981, 1992 E 1999 (1.000 PESSOAS)

\begin{tabular}{|l|r|r|r|c|c|}
\hline \multicolumn{1}{|c|}{$\begin{array}{c}\text { RAMOS DE } \\
\text { ATIVIDADES }\end{array}$} & \multicolumn{3}{|c|}{ Rio Grande } & \multicolumn{2}{c|}{$\begin{array}{c}\text { Taxas de crescimento } \\
\text { (\% a.a.) }\end{array}$} \\
\hline Posição na ocupação & \multicolumn{1}{|c|}{1981} & 1992 & 1999 & \multicolumn{1}{c|}{$81 / 92^{\mathrm{a}}$} & \multicolumn{1}{c|}{$92 / 99^{\mathrm{b}}$} \\
\hline Ativ. agrícolas & $1.160,8$ & 964,0 & 789,4 & $-1,7 * *$ & $-2,6 * * *$ \\
Empregados & 146,3 & 145,9 & 127,2 & 0,0 & $-2,5$ \\
Conta própria & 379,8 & 326,7 & 284,3 & $-1,4 *$ & $-1,6 * *$ \\
Empregadores & 22,2 & 26,8 & 14,7 & 1,7 & $-7,2^{*}$ \\
Não-remunerado & 612,5 & 464,6 & 363,0 & $-2,5 * * *$ & $-3,1 * * *$ \\
\hline Ativ. não-agrícolas & 276,5 & 297,1 & 352,4 & 0,7 & $2,7 * * *$ \\
Empregados & 207,1 & 234,5 & 259,1 & 1,1 & 2,0 \\
Conta própria & 47,6 & 46,4 & 64,7 & $-0,2$ & $4,5 * * *$ \\
Empregadores & 7,3 & 7,0 & 11,9 & $-0,4$ & $10,3 * * *$ \\
Não-remunerado & 14,5 & 9,2 & 15,3 & $-4,1 *$ & 3,0 \\
\hline Total da PEA rural & $1.437,3$ & $1.261,1$ & $1.141,7$ & $-1,2 * * *$ & 1,3 \\
\hline
\end{tabular}

a Teste $t$ indica se a diferença entre os dois anos é significativa ou não.

${ }^{\mathrm{b}}$ Estimativa do coeficiente de uma regressão log-linear contra o tempo. Neste caso, o teste t indica a existência ou não de uma tendência nos dados.

$(* * *),(* *),(*)$ significam respectivamente $5 \%, 10 \%$ e $20 \%$.

Fonte: Núcleo de Economia Agrícola do IE/Unicamp, Projeto Rurbano (Tabulações Especiais).

Conforme aponta a Tabela 3, um dos aspectos a ser ressaltado é a expressiva participação das pessoas ocupadas em atividades não-remuneradas e por conta própria. Em geral, essas ocupações são exercidas por agricultores familiares que possuem uma pequena propriedade e executam suas atividades utilizando-se apenas do trabalho da família, sem contratar nenhum tipo de assalariado. $\mathrm{O}$ outro aspecto que merece ser reiterado referese à redução total da PEA agrícola, que passou de 1.160.800, em 1981, para apenas 789.400 em 1999, com destaque para a diminuição dos não-remurerados $(-3,1 \%$ a.a.) e dos que trabalham por conta própria (-1,6\% a.a.), no período 1992-1999. Somadas, essas duas últimas categorias parecem indicar que a queda expressiva da população rural ocupada em atividades agrícolas está ligada à diminuição do número de agricultores familiares no Estado do Rio Grande do Sul.

Tais evidências estão em consonância com as dificuldades crescentes que os agricultores familiares encontram para se manter no meio rural e, sobretudo, nas atividades agrícolas nos anos recentes. Esse processo de abandono do campo é particularmente mais expressivo entre os agricultores que produzem leite, que sofrem intensa concorrência com os produtos importa- 
dos dos países do Mercosul e aqueles ligados às agroindústrias de frangos e suínos, pois estas vêm implementando políticas de enxugamento em seus quadros de integrados para obter melhores escalas de produtividade.

Contudo, há outros fatores que explicam essa redução do emprego agrícola, como a diminuiç̧ão vertiginosa dos preços dos principais produtos agrícolas, de um lado, e o aumento da produtividade dos principais cultivos da agropecuária gaúcha. Segundo estudos de Lopes (1997, p. 11), entre 1991 e 1995 os preços recebidos pelos produtores caíram $19 \%$ no caso do arroz, $27 \%$ no caso do milho, $36 \%$ no caso da soja e $54 \%$ no caso do trigo, o que, sem dúvida, ocasionou uma queda nas rendas dos agricultores e, conseqüentemente, dificuldades para manter suas atividades e escalas de produção. Por outro lado, verifica-se uma elevação da produtividade da agropecuária que, segundo estudos da Fundação de Economia e Estatística (Grando, 1996), aumentou em 2,4\% ao ano entre 1980 e 1995 para o conjunto do Estado. Nas duas últimas décadas, a agricultura gaúcha ampliou não somente os volumes da produção primária como também a sua produtividade, pois esse aumento se fez com um número cada vez menor de pessoas ocupadas nas atividades agropecuárias. Em 1980, cultivavam-se em torno de 8 milhões de hectares com grãos no Rio Grande do Sul, obtendo-se cerca de 12,3 milhões de toneladas. Em 1995, a área cultivada com grãos reduziu-se para 6,3 milhões de hectares mas a produção havia subido para 17,3 milhões de toneladas. Portanto, em quinze anos, a produção de grãos no Estado cresceu $41 \%$ e a superfície cultivada reduziu-se em cerca de $20,4 \%$, aumentando o rendimento médio por hectare de 1,53 t/ha em 1980 para 2,72 t/ha em 1995.

Essas informações parecem sintomáticas das características e tendências que a agricultura e o emprego rural tendem a assumir nas próximas décadas. Ou seja, um setor econômico concentrado em um número cada vez menor de unidades produtivas, porém cada vez mais tecnificadas, eficientes e produtivas, e tendendo a gerar cada vez menos empregos diretos nas atividades agropecuárias.

Com relação à participação dos trabalhadores rurais assalariados (empregados) em atividades agrícolas, verifica-se que nos anos mais recentes houve uma queda de 19 mil pessoas nesta categoria, entre 1992 e 1999. Essa redução está relacionada, provavelmente, às pressões econômicas enfrentadas por culturas nas quais geralmente é utilizada força de trabalho contratada, como é o caso da lavoura de arroz e, em menor escala, da fumicultura ou da produção de outros cereais (Schneider e Navarro, 2000).

No que se refere às ocupações não-agrícolas da PEA gaúcha com domicílio rural, os dados das PNADs indicam que a maioria dos indivíduos está ocupada na condição de empregado (em torno de $73,5 \%$, em 1999). No entanto,é preciso destacar o expressivo crescimento de 10,3\% a.a., entre 1992-1999, da categoria dos empregadores com domicílio rural que atuavam em atividades não- 
agrícolas, indicando, o crescimento das atividades autônomas de pequenos empreendedores no meio rural, o que, de certo modo, corrobora o crescimento do ramo da prestação de serviços antes destacado. Na mesma medida, também se destaca a ocupação das pessoas em atividade não-agrícolas por conta própria, que cresceu a uma taxa de 4,5\% a.a. entre 1992-1999. Este aumento pode ser atribuído ao incremento das atividades não-agrícolas da população com domicílio rural, envolvidas com o beneficiamento e o processamento de produtos alimentares como conservas, doces, compotas, derivados de leite, de carne, etc., típicas da assim chamada agroindústria familiar. A análise do desempenho das diferentes ocupações da população rural gaúcha nas últimas duas décadas permite afirmar que ainda há forte presença do trabalho familiar, evidenciada na forma de ocupações por conta própria, ocupações não-remuneradas.

No entanto, uma avaliação de conjunto dos dados apresentados mostra que, na década de 1980, a PEA rural ocupada regrediu a uma taxa de -1,2\% a.a.passando de 1,437 milhão de pessoas para 1,261 milhão. Na década de 1990, essa tendência de queda continuou, embora menos intensa, pois a PEA rural total diminuiu para 1,141 milhão de pessoas, registrando uma taxa negativa de apenas $0,7 \%$ a.a. Mais significativo, contudo, foi o desempenho da PEA rural ocupada em atividades agrícolas, que entre 1981-1992 reduziu-se em 1,7\% a.a. e em 2,6\% a.a. entre 1992-1999, passando de 1,160 milhão pessoas ocupadas em 1981 para 964 mil ocupados em 1992 e para 789 mil em 1999, o que representa uma perda de 196 mil ocupações entre 1981-92 e 174,62 entre 1992-99. Essa redução menos acentuada da PEA rural na década de 1990 está estreitamente relacionada ao crescimento expressivo do número de ativos que têm domicílios em áreas rurais do Rio Grande do Sul mas que estão ocupados em atividades não-agrícolas. APEArural ocupada em atividades não-agrícolas aumentou de 297 mil em 1992 para 352 mil em 1992 (o que corresponde a um aumento de 55,24 mil ocupações), registrando uma taxa anual de crescimento de 2,7\% entre 1992 e 1999 e de 4,5\% a.a., quando tomados apenas os anos entre 1996 e 1999. Embora significativo, esse aumento não foi suficiente para compensar a perda dos ocupados em atividades agrícolas.

\subsection{ADINÂMICADAS ATIVIDADES AGRÍCOLAS ENÃO-AGRÍCOLAS EM SANTACATARINA}

Nas últimas décadas, a agricultura do Estado de Santa Catarina também foi submetida a um marcado processo de transformação de sua base produtiva, especialmente no que se refere à alteração de sua base tecnológica. À semelhança do ocorrido no Rio Grande do Sul, o processo de modificação das relações de trabalho e dos processos produtivos intensificouse a partir de meados da década de 1970, mediante a crescente incorpora- 
ção dos insumos modernos, integrando os agricultores familiares à nova dinâmica econômica daquele período. Em certa medida, pode-se afirmar que a modernização da agricultura catarinense, especialmente no tocante à região Oeste daquele Estado, decorre, de fato, da difusão do processo modernizante da metade norte do Rio Grande do Sul, por um lado, e, também, pela notável expansão da agroindústria integradora de pequenos animais (aves e suínos). Como é notório, Santa Catarina é o maior Estado produtor de produtos derivados de suínos e aves (com indústrias concentradas no Oeste daquele Estado) e o Brasil, por sua vez, é um dos maiores exportadores mundiais daqueles produtos.

No entanto, conforme já ressaltado, o processo de modernização não percorreu uma trajetória linear e tampouco generalizou-se de forma homogênea em todas as regiões e entre todas as categorias de agricultores. É por isso que determinadas regiões integraram-se mais rapidamente que outras aos novos circuitos econômico-financeiros. Não obstante essa ressalva, uma retrospectiva das transformações da estrutura agrária e da economia agrícola catarinense nas duas últimas décadas revela características bastante similares ao que ocorreu em outras regiões brasileiras, especialmente no Rio Grande do Sul. Os dados que serão analisados a seguir também foram obtidos através das mesmas tabulações especiais da PNAD, conforme destacado anteriormente. As duas primeiras Tabelas (4a e 4b) fornecem um quadro sintético das principais transformações que ocorreram em Santa Catarina, na década de 1980 e nos anos da década atual. Seguindo a tendência apontada anteriormente em relação ao desempenho das atividades agrícolas e não-agrícolas no Brasil e na região Sul, os dados em relação a Santa Catarina indicam um comportamento semelhante da PEA rural ocupada. Em primeiro lugar, observa-se que a população com domicílio rural interrompeu sua tendência de redução e a taxa de crescimento da população urbana, que entre 1981-1992 foi de 4,5\% a.a, diminuiu para 2,8\% a.a. entre 1992-1999 indicando uma diminuição dos deslocamentos populacionais do campo para as cidades. 


\section{Tabela 4a}

SANTACATARINAE BRASIL.POPULAÇÃOEM IDADEATIVA(PIA), OCUPADAENÃO-OCUPADA SEGUNDOO LOCALDEDOMICÍLIO E O SETOR DE ATIVIDADE, 1981-1999 (1.000 PESSOAS)

\begin{tabular}{|l|l|c|c|c|c|c|c|}
\hline \multirow{2}{*}{} & \multicolumn{2}{|c|}{1981} & \multicolumn{2}{c|}{1992} & \multicolumn{2}{c|}{1999} \\
\cline { 3 - 9 } & SC & BR & SC & BR & SC & BR \\
\hline Urbana & $1.577,5$ & $64.669,1$ & $2.559,2$ & $89.510,7$ & $3.091,3$ & $104.693,5$ \\
\hline Rural & $1.203,8$ & $24.233,8$ & $1.079,0$ & $23.784,5$ & $1.083,0$ & $25.402,2$ \\
\hline $\begin{array}{l}\text { PEA } \\
\text { rural } \\
\text { ocupada }\end{array}$ & Agrícola & 599,7 & $10.735,9$ & 629,1 & $11.192,5$ & 465,8 & $10.230,5$ \\
\hline $\begin{array}{l}\text { PEA } \\
\text { rural } \\
\text { não-agrícola } \\
\text { ocupada }\end{array}$ & $\begin{array}{l}\text { Nesocupados } \\
\text { ou procurando } \\
\text { emprego }\end{array}$ & 6,1 & $13.060,8$ & 179,7 & $3.496,7$ & 245,4 & $4.620,0$ \\
\cline { 2 - 8 } & Aposentados & 60,9 & $1.240,0$ & 59,9 & $1.517,1$ & 99,4 & $2.235,8$ \\
\hline
\end{tabular}

${ }^{a}$ Teste $t$ indica se a diferença entre os dois anos é significativa ou não.

${ }^{\mathrm{b}}$ Estimativa do coeficiente de uma regressão log-linear contra o tempo. O teste $\mathrm{t}$ indica a existência ou não de uma tendência nos dados.

$(* * *),(* *),(*)$ significam respectivamente $5 \%, 10 \%$ e $20 \%$.

Fonte: Núcleo de Economia Agrícola do IE/Unicamp, Projeto Rurbano (Tabulações Especiais).

Tabela 4b

SANTA CATARINA E BRASIL. TAXA DE CRESCIMENTO POPULAÇÃO EM IDADE ATIVA (PIA), OCUPADA E NÃO-OCUPADA SEGUNDO O LOCAL DE DOMICÍLIO E O SETOR DE ATIVIDADE, 1981-1999

\begin{tabular}{|c|c|c|c|c|c|}
\hline \multirow{2}{*}{\multicolumn{2}{|c|}{ Taxa de crescimento (\% a.a.) }} & \multicolumn{2}{|c|}{$1981 / 92^{a}$} & \multicolumn{2}{|c|}{$1992 / 99^{b}$} \\
\hline & & $\mathrm{SC}$ & $\mathrm{BR}$ & $\mathrm{SC}$ & $\mathrm{BR}$ \\
\hline \multicolumn{2}{|l|}{ Urbana } & $4,5 * * *$ & $3,0 * * *$ & $2,8 * * *$ & $2,3 * * *$ \\
\hline \multicolumn{2}{|l|}{ Rural } & $-1,0$ & $-0,2^{*}$ & 0,1 & $0,9 * * *$ \\
\hline \multirow{2}{*}{$\begin{array}{l}\text { PEA rural } \\
\text { ocupada }\end{array}$} & Agrícola & 0,4 & $0,4^{* * *}$ & $-4,4 * * *$ & $-1,7 * * *$ \\
\hline & Não-agrícola & 0,5 & $1,2 * * *$ & $4,1 * * *$ & $3,7 * * *$ \\
\hline \multirow{3}{*}{$\begin{array}{l}\text { PEA rural } \\
\text { não ocupada }\end{array}$} & $\begin{array}{l}\text { Desocupados ou } \\
\text { procurando emprego }\end{array}$ & $5,4^{*}$ & $7,6 * * *$ & $22,1 * * *$ & $10,8 * * *$ \\
\hline & Aposentados & $-0,1$ & $1,9 * * *$ & $6,5 * * *$ & $5,7 * * *$ \\
\hline & Outros & $-5,4 * * *$ & $-2,0 * * *$ & $3,0 * * *$ & $1,4 * * *$ \\
\hline
\end{tabular}

${ }^{a}$ Teste $t$ indica se a diferença entre os dois anos é significativa ou não.

${ }^{\mathrm{b}}$ Estimativa do coeficiente de uma regressão log-linear contra o tempo. O teste $\mathrm{t}$ indica a existência ou não de uma tendência nos dados.

$(* * *),(* *),(*)$ significam respectivamente $5 \%, 10 \%$ e $20 \%$.

Fonte: Núcleo de Economia Agrícola do IE/Unicamp, Projeto Rurbano (Tabulações Especiais). 
Como pôde-se observar, entre os que estavam ocupados em atividades agrícolas houve uma redução de 1,7\% entre 1992 e 1999, o que implicou o desaparecimento de aproximadamente 164 mil postos de trabalho na agricultura. Já entre os que também possuíam domicílio rural mas estavam ocupados em atividade não-agrícolas, verificou-se um desempenho muito diferente, pois apresentaram um crescimento de 4,1\% a.a. entre 1992-1999. Frente a esta diferença, pode-se afirmar que houve uma espécie de compensação parcial entre o crescimento das ocupações nas atividades nãoagrícolas em relação à queda das ocupações agrícolas. Esse desempenho da PEA rural (ocupada em atividades agrícolas e não-agrícolas) catarinense é muito similar ao verificado no conjunto da região Sul.

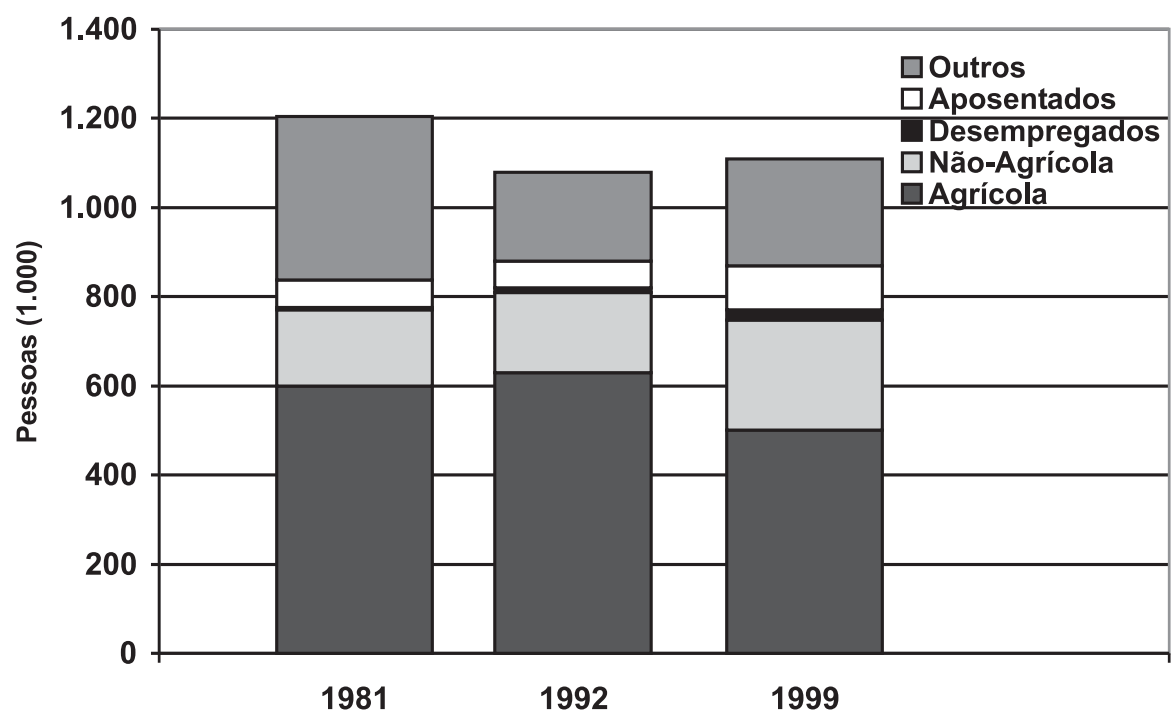

Gráfico 3. Santa Catarina. PEA rural ocupada em atividades agrícolas e não-agrícolas, PEA rural procurando emprego (desempregados), aposentados outros, 1981-1999

Fonte: Projeto Rurbano. Tabulações Especiais das PNADs.

Uma análise de conjunto da PEA rural catarinense permite identificar alguns traços característicos de seu perfil nos anos mais recentes. Embora as ocupações agrícolas continuem a ser predominantes na estrutura agrária de Santa Catarina, o Gráfico 3 permite visualizar uma tendência de modificação, pois é visível a evolução das ocupações não-agrícolas entre a população rural. Essa queda da população ocupada em atividades agrícolas vem contribuindo 
de modo decisivo para redução geral dos ativos rurais que, em 1981, era de 1.203 milhão de pessoas e, em 1992, haviam se reduzido para 1.079 milhão, tendo aumentado um pouco na década de 1990, chegando a 1.083 milhão em 1999.

As razões para redução da PEA ocupada em atividades agrícolas parecem estar ligadas ao aprofundamento do processo de modernização tecnológica da agricultura catarinense, cada vez menos demandante de força de trabalho. Mas há dois outros fenômenos a serem considerados: o aumento do desemprego e o crescimento do número de aposentados no campo. Em Santa Catarina, o total de pessoas em idade ativa que, na semana em que o IBGE realizava o levantamento dos dados da PNAD, estavam procurando emprego, aumentou de $6.100 \mathrm{em} 1981$ para $23.600 \mathrm{em} \mathrm{1999,}$ com taxas de crescimento expressivas de 5,4\% a.a., entre 1981-1992, e de 22,1\% a.a., entre 1992-1999. Os aposentados, por sua vez, passaram de pouco mais de 60 mil em 1981 para 99,5 mil em 1999, o que representa em torno de $9 \%$ do total da população rural. Esse aumento ocorreu integralmente na década de 1990, entre 1992 e 1999 houve um aumento de quase 40 mil aposentados com domicílio rural, o que decorreu da extensão da legislação previdenciária aos trabalhadores rurais.

Em razão do expressivo crescimento das atividades não-agrícolas no meio rural catarinense na década de 1990, torna-se relevante detalhar os ramos econômicos que mais se destacaram na geração dessas novas ocupações; quais sejam, os ramos da indústria da construção, da administração pública, da indústria da transformação e da prestação de serviços, conforme indica a Tabela 5, a seguir.

Mattei (1999), ao averiguar que as maiores taxas de crescimento dos ramos de atividades não-agrícolas situavam-se na indústria da construção, na administração pública e na prestação de serviços, concluiu que este era um indicador do processo de "urbanização do meio rural em Santa Catarina", cuja característica principal seria a extensão para ambientes rurais dos serviços de infra-estrutura das sociedades urbanas.

A explicação para o crescimento desses ramos de atividades econômicas assemelha-se bastante ao que foi apresentado em relação ao caso gaúcho. O crescimento das atividades ligadas à indústria de transformação (4,3\% a.a. entre 1992-1999), por exemplo, parece estar relacionado à expansão do processo de agroindustrialização, seja em maior escala, seja através dos processamentos domésticos, de pequena escala, dos produtos agrícolas, iniciativas que têm sido disseminadas no meio rural, especialmente quando relacionadas a produtos lácteos, carnes ou frutas (geléias, doces, etc.). 
Tabela 5

SANTA CATARINA. RAMOS DEATIVIDADES NÃO-AGRÍCOLAS DAPEA OCUPADADE 10 ANOS OU MAIS, RESIDENTEEM DOMICÍLIOS RURAIS, 19921999 (1.000 PESSOAS)

\begin{tabular}{|l|c|c|c|c|c|}
\hline \multirow{2}{*}{\multicolumn{1}{|c|}{ Ramos de Atividades }} & \multicolumn{2}{|c|}{ Santa Catarina } & \multicolumn{2}{c|}{$\begin{array}{r}\text { Taxas Crescimento } \\
\text { (\%a.a.) }\end{array}$} \\
\cline { 2 - 6 } & 1981 & 1992 & 1999 & $1981 / 92^{\mathrm{a}}$ & $1992 / 99^{\mathrm{b}}$ \\
\hline Indústria da transformação & 71,5 & 74,6 & 101,2 & 0,4 & $4,3 * * *$ \\
Indústria da construção & 12,5 & 15,8 & 28,5 & 2,2 & $7,9 * * *$ \\
Outras atividades industriais & 4,9 & 3,4 & - & $-3,3$ & - \\
Comércio de mercadorias & 13,6 & 22,0 & 19,2 & $4,5 *$ & $-1,9$ \\
Prestação de serviços & 21,5 & 36,7 & 51,2 & $5,0 * *$ & $4,5 *$ \\
Serviços auxil. ativ. & 2,3 & 4,0 & 5,2 & 5,2 & - \\
econômicas & 10,2 & 6,2 & 11,1 & $-4,4$ & 2,7 \\
Transporte e comunicação & 22,3 & 11,3 & 15,1 & $-6,0 * * *$ & 3,0 \\
Ramo social & 8,3 & 4,5 & 10,5 & $-5,4 *$ & $10,6 * * *$ \\
Administração pública & 3,0 & 1,1 & - & $-8,6 * *$ & - \\
Outras atividades & 170,2 & 179,7 & 245,4 & 0,5 & $4,1 * * *$ \\
\hline \multicolumn{1}{|c|}{ TOTAL } & \multicolumn{5}{|c|}{} \\
\hline
\end{tabular}

${ }^{\text {a }}$ Teste $\mathrm{t}$ indica se a diferença entre os dois anos é significativa ou não.

${ }^{\mathrm{b}}$ Estimativa do coeficiente de uma regressão log-linear contra o tempo. Neste caso, o teste t indica a existência ou não de uma tendência nos dados.

$(* * *),(* *),(*)$ significam respectivamente $5 \%, 10 \%$ e $20 \%$.

Fonte: Núcleo de Economia Agrícola do IE/Unicamp, Projeto Rurbano (Tabulações Especiais).

O crescimento da indústria da construção (7,9\% a.a. no período de 1992 a 1999) parece ser uma conseqüência da própria expansão das atividades de transformação industrial. Além disso, as atividades ligadas à construção civil desenvolvem-se também por sua ligação à administração pública, que foi um ramo de expressiva expansão no período (10,6\% a.a.). Neste último caso, o crescimento decorre de obras públicas que são impulsionadas pelo grande número de novos municípios que surgiram ao longo da década de 1990 no Estado de Santa Catarina. Não é sem razão que a dinamização das atividades não-agrícolas de transformação industrial, de administração pública e construção civil igualmente estimulam a expansão dos setores de transporte e comunicações que, entre os anos citados, cresceram 4,8\% a.a., indicando, talvez, uma intensificação das relações entre o espaço rural e urbano, já que o aumento mais significativo ocorreu no transporte de pessoas e de produtos de origem agrícola.

O desempenho das principais categorias da PEA rural em Santa Catarina, nas duas últimas décadas, é apresentado na Tabela 6. Frente à queda global dos ocupados nas atividades agrícolas (4,4\% a.a. entre 1992-1999), é interessante notar 
que esta redução ocorreu, de modo predominante, nas categorias em que se encontram os agricultores familiares, nas quais incluem-se os indivíduos ocupados por conta própria (3,2\% a.a.) e os não-remunerados (queda de 6,1\% a.a.). Essa diminuição torna-se ainda mais significativa quando se comparam os valores absolutos entre o período de duas décadas, de 1981 a 1999. O que fica evidente nessa comparação é que houve, de fato, uma tendência de queda no período. Isto significa dizer que a crise do emprego na agricultura catarinense continua a atingir os proprietários de menor tamanho e/ou aquelas unidades baseadas no trabalho familiar. Esse fato corrobora a hipótese inicial desse capítulo, ao afirmar que está em curso um aprofundamento do padrão tecnológico, nos anos mais recentes, na agricultura da região meridional do Brasil, cujos efeitos concentram-se na diminuição das formas de ocupação que tipicamente identificam-se com a categoria dos agricultores familiares.

Tabela 6

SANTACATARINA. EVOLUÇÃO DAPOPULAÇÃO OCUPADA COM DOMICÍLIO RURAL, SEGUNDO APOSIÇÃO NAOCUPAÇÃO, EM 1981,1992 E 1999 (1.000 PESSOAS)

\begin{tabular}{|l|r|r|r|l|l|}
\hline Ramos de Atividades & \multicolumn{3}{|c|}{ Santa Catarina } & \multicolumn{2}{|c|}{$\begin{array}{r}\text { Taxas Crescimento } \\
\text { (\%a.a.) }\end{array}$} \\
\hline Posição na ocupação & 1981 & 1992 & 1999 & $1981 / 92^{\mathrm{a}}$ & $1992 / 99^{\mathrm{b}}$ \\
\hline Ativ. agrícolas & 599,7 & 629,1 & 465,9 & 0,4 & $-4,4 * * *$ \\
Empregados & 44,3 & 66,1 & 59,3 & $3,7 * *$ & $-0,2$ \\
Conta própria & 203,1 & 202,3 & 165,2 & 0,0 & $-3,2 * * *$ \\
Empregadores & 6,1 & 10,2 & 7,6 & 4,8 & $-5,3$ \\
Não-remunerados & 346,3 & 350,4 & 233,8 & 0,1 & $-6,1 * * *$ \\
\hline Ativ. não-agrícolas & 170,2 & 179,7 & 245,4 & 0,5 & $4,1 * * *$ \\
Empregados & 144,1 & 150,9 & 203,6 & 0,4 & $4,1 * *$ \\
Conta própria & 21,2 & 22,6 & 32,0 & 0,6 & 4,2 \\
Empregadores & 1,9 & 2,8 & 7,0 & 3,7 & - \\
Não-remunerados & 3,0 & 3,4 & - & 1,0 & - \\
\hline Total & 769,9 & 808,8 & 711,3 & 0,4 & $-2,1 * * *$ \\
\hline
\end{tabular}

\footnotetext{
${ }^{a}$ Teste $t$ indica se a diferença entre os dois anos é significativa ou não.

${ }^{\mathrm{b}}$ Estimativa do coeficiente de uma regressão log-linear contra o tempo. Neste caso, o teste t indica a existência ou não de uma tendência nos dados.

$(* * *),(* *),(*)$ significam respectivamente $5 \%, 10 \%$ e $20 \%$.

Fonte: Núcleo de Economia Agrícola do IE/Unicamp, Projeto Rurbano (Tabulações Especiais).
}

Entre a população com domicílio rural, ocupada em atividades não-agrícolas da PEA de Santa Catarina, a categoria que apresentou o maior cresci- 
mento foi a dos empregadores que passou de 1,9 mil para 7 mil de 1981 a 1999 , ainda que em termos absolutos seja pouco expressivo. No entanto, o que deve ser ressaltado é o aumento de 4,1\% a.a., entre 1992-1999, da categoria dos empregados em atividade rurais não-agrícolas da PEA catarinense. Nesse sentido, pode-se afirmar que o crescimento das atividades não-agrícolas no meio rural catarinense passa tanto pelo aumento de empreendedores, que vêm ampliando suas atividades econômicas nesse espaço, como da categoria dos empregados.

\subsection{AGRICULTURAFAMILIAR,DESCENTRALIZAÇÃO INDUSTRIALE PLURIATIVIDADE}

Nas últimas décadas, a literatura brasileira dedicada ao estudo das transformações da agricultura familiar passou a conferir ampla atenção às mudanças do padrão tecnológico e aos efeitos sociais e econômicos por ele engendrados no mundo rural. Esse foco relativamente limitado de análise pode ter contribuído para a generalização de uma visão apenas parcial das mudanças que ocorreram na estrutura agrária do Brasil meridional.Embora tenha ocorrido, como se sabe, uma ampla difusão de novas tecnologias nessa região, em geral acompanhadas de efeitos sociais, econômicos e ambientais nem sempre benéficos, isso não quer dizer que sua generalização estendeu-se a todas áreas e a todos os sistemas de cultivo e/ou de criação. Mesmo que os estudos tenham sido pródigos em abordar a natureza dessas mudanças técnicas, bem como sua interface com a "revolução verde", ainda são pouco conhecidas as transformações propriamente sociais e econômicas que afetaram as populações de regiões rurais que não foram abarcadas por esse padrão dominante (entenda-se, como típico, no sul do Brasil, o modelo agroindustrial baseado no cultivo de monoculturas de grãos, a criação de aves e suínos, o leite e determinadas culturas frutíferas como uva e maçã) ou, ainda, aquelas regiões nas quais a modernização das propriedades agrícolas ocorreu em contextos de mudanças no mercado de trabalho não-agrícola, patrocinadas pela intensa industrialização experimentada pelo Brasil, especialmente a partir dos anos setenta.

Essas alterações ocorreram em áreas de agricultura familiar nas quais, não obstante os processos de produção agrícola terem sofrido alterações nas últimas décadas, tal atividade não é mais a única e, em certos casos, nem mesmo a mais importante atividade econômica das famílias que habitam nos espaços rurais. Ao contrário do que ocorreu na maior parte das regiões agrícolas do Sul do Brasil, no período recente, certas áreas de colonização antiga como a chamada Colônia Velha alemã, no Rio Grande do Sul (hoje composta pelas microrregiões do Vale do Sinos, Encosta da Serra, Vale do Caí e Vale do Taquari) e a região do Vale do Itajaí (dividida entre as microrregiões 
do Baixo, Médio e Alto Vale do Itajaí), em Santa Catarina, estão a indicar uma face virtualmente desconhecida do desenvolvimento agrícola e rural recente.

Nessas regiões, a partir da década de 1970, a estrutura agrária foi rapidamente alterada pela crescente mercantilização das relações sociais e econômicas, afetando sobretudo os agricultores familiares. Na Colônia Velha alemã gaúcha, por exemplo, reduziram-se de modo considerável as atividades agrícolas no espaço rural, fazendo com que os colonos passassem a produzir praticamente somente para a sua subsistência (Schneider, 1994, 1999). Já no Vale do Itajaí, em Santa Catarina, embora uma parcela pequena dos agricultores tenha-se modernizado tecnologicamente através da orizicultura irrigada e da integração agroindustrial, a maior parte dos habitantes do meio rural passou a buscar, cada vez mais intensamente, variadas formas de complementação de renda em atividades não-agrícolas (Anjos, 1995; Seyferth, 1987; Raud, 1999).

Tais áreas, que constituem o alvo deste trabalho, caracterizam-se pela predominância das pequenas unidades familiares, oriundas dos processos de ocupação fundiária realizados através do assentamento de imigrantes de origem alemã e italiana, iniciados no século XIX. A partir da década de 1970, o sistema produtivo colonial adotado pelos colonos teuto-brasileiros nessas áreas entrou em crise. ${ }^{65}$ Os colonos começaram a encontrar dificuldades para garantir sua reprodução social a partir dos ganhos obtidos exclusivamente com a produção agrícola. Conforme exposto em outro trabalho, a crise do sistema produtivo colonial resultou do somatório de vários fatores (Schneider, 1999). Entre outros, pode-se destacar o sistema de transferência da terra por mecanismos de herança, que provocou um rápido parcelamento das propriedades, intensificando o uso do solo e levando à degradação da sua fertilidade e à conseqüente redução da produtividade. No entanto, o fator mais importante parece ter sido a fragilização compulsória dos colonos em relação aos agentes mercantis externos, que compravam seus produtos agrícolas ao preço que desejavam.

Esse processo de crise e regressão das atividades agrícolas gerou um excedente de mão-de-obra, composto pelos descendentes e filhos dos pequenos agricultores familiares, dada a impossibilidade de expansão da fronteira agrícola e até mesmo as dificuldades para emigrar para outras regiões. Grande parte dessa força de trabalho passou a se empregar nas indús-

\footnotetext{
${ }^{65} \mathrm{O}$ sistema produtivo aqui chamado de colonial constitui a forma de produção agrícola utilizada pelos camponeses (colonos) durante o processo de colonização. Em linhas gerais, pode ser caracterizado pela "expansão constante da zona pioneira" (Waibel, 1949, 1955), pela prática da rotação de terras, pela produção policultora de produtos de consumo básico, como feijão, milho, batata e mandioca, e pela relação dependente em relação aos agentes mercantis externos (vendeiros e comerciantes). Para maiores informações, consultar Schneider (1994, 1999) e Raud (1999).
} 
trias de calçados no Rio Grande do Sul e nas fábricas de tecelagem em Santa Catarina. A partir de meados da década de 1970, o desenvolvimento das indústrias nessas duas regiões experimentou um processo de expansão descentralizada, que deslocou fábricas inteiras (ou pelo menos algumas das fases do processo produtivo) para as pequenas cidades do interior ou mesmo para as comunidades rurais periurbanas, próximas às cidades-pólo, como Novo Hamburgo, no Rio Grande de Sul, e Blumenau, em Santa Catarina. Desse modo, as empresas passaram a contar com maiores facilidades para recrutar os colonos, sobretudo os mais jovens e, de modo especial, as mulheres (principalmente nas indústrias têxteis do Vale do Itajaí).

Mas o processo de industrialização descentralizado não ocorreu apenas devido ao deslocamento das empresas de uma cidade à outra, ou mesmo entre regiões. Na verdade, até mesmo nas pequenas localidades a presença das indústrias é bastante antiga (especialmente em Santa Catarina, na região do médio Vale do Itajaí) e possui uma estreita ligação com o artesanato de origem colonial. Nas décadas de 1960 e 1970, contudo, houve um rápido impulso dessas atividades, que ampliaram suas escalas de produção e especialmente a absorção de força de trabalho.

Conforme já salientado, as transformações que ocorreram na estrutura agrária da Colônia Velha de origem alemã no Rio Grande do Sul e no Vale do Itajaí, em Santa Catarina, não estão unicamente relacionadas aos aspectos tecnológicos específicos da produção agrícola, mas particularmente às mudanças que ocorreram no mercado de trabalho industrial. A inserção de membros das famílias rurais em atividades não-agrícolas está relacionada ao desenvolvimento industrial descentralizado, que vem exercendo forte atração sobre a população que reside no meio rural, especialmente entre os mais jovens. Nessas duas áreas cresce o número de unidades familiares nas quais uma parcela significativa das rendas que compõem o orçamento doméstico advém de atividades não diretamente ligadas à agricultura e ao trabalho na terra. Nessas áreas é também cada vez mais freqüente o comportamento de membros das famílias que, residindo no meio rural, buscam empregos e fontes de renda em atividades não-agrícolas, especialmente industriais, sejam elas de caráter temporário ou permanente.

Nos países desenvolvidos, especialmente na Europa e na América do Norte, como já discutido, esse fenômeno tem sido denominado de pluriatividade ou agricultura em tempo parcial e caracteriza-se por uma situação em que a família compõe seu orçamento com base na conjugação das receitas da produção agrícola e o desempenho de outras atividades rentáveis fora da propriedade. Embora guarde semelhança com o que Freitas Marcondes (1962) chamou de "absenteísmo agrário", na década de 1950, referindo-se aos colonos dos "bairros rurais" do interior de São Paulo, que residiam no meio 
rural mas trabalhavam em atividades não-agrícolas, a pluriatividade aqui analisada parece distinguir-se das formas produtivas e organizacionais usuais encontradas na estrutura agrária brasileira ou, pelo menos, ainda pouco estudadas (uma vez que os estudos sobre esse tema apenas recentemente estão sendo desenvolvidos). A pluriatividade não é uma particularidade regional, conforme já indicado nos capítulos anteriores, mas suas características e especificidades variam segundo os contextos, sendo por isso interessante pesquisar quais seus traços principais nas regiões de colonização européia do sul do País.

Na região meridional brasileira, a emergência dessa forma de organização parece estar associada aos impactos que os processos de industrialização dos setores coureiro-calçadista no Rio Grande do Sul e têxtil em Santa Catarina exerceram sobre a agricultura familiar dessas regiões, a partir da década de $1970 .{ }^{66}$ A partir deste período, as indústrias estabeleceram novas estratégias de atração da mão-de-obra mediante a descentralização das fábricas localizadas nas cidades para o meio rural. As indústrias passaram a deslocar unidades produtivas para as áreas rurais próximas, gerando uma forte atração sobre as populações residentes no meio rural, especialmente dos jovens. Através desses mecanismos, as indústrias foram as grandes responsáveis pelo alargamento do mercado local de força de trabalho, impactando diretamente a agricultura familiar das regiões, que iniciou um processo de mudança não apenas dos formatos organizacionais e produtivos como também sociais e culturais.

Desse modo, o acesso às atividades não-agrícolas possibilitou a emergência de novas formas de obtenção de rendas e permitiu aos agricultores familiares a redefinição do processo produtivo e da organização do trabalho. Atualmente, boa parte dos proprietários rurais das mencionadas regiões tenta adequar-se ao mercado de trabalho, seja através do cultivo de produtos menos intensivos no uso da força de trabalho, como é o caso da cultura da acácia no Rio Grande do Sul, ou até mesmo buscando dividir o tempo de trabalho na propriedade conforme a natureza da jornada de trabalho nas atividades não-agrícolas.

No Vale do Itajaí catarinense, ao estudar esse fenômeno, Seyferth constatou a emergência de uma nova categoria social, por ela denominada de colonos-operários $(1984,1987)$. Segundo a autora, o colono-operário é aquele trabalhador que se encontra em uma situação de auspendler (deslocamento pendular), ou seja, que diariamente executa o movi-

\footnotetext{
${ }^{66}$ Sobre os processos de industrialização das regiões mencionadas, consultar Seyferth (1974), Hering (1987), Roche (1969) e, mais recentemente, Schneider (1999) e Raud (1999).
} 
mento pendular de deslocar-se do meio rural, onde mora, para trabalhar nas fábricas, localizadas no centros urbanos ou até mesmo em povoados rurais mais populosos, onde existam unidades industriais. Já na região da Colônia Velha alemã do Rio Grande do Sul, conforme mostramos em outro trabalho (Schneider, 1999), o processo de descentralização e interiorização das indústrias de calçados na década de 1980 dispensou os colonos de viajar para trabalhar, uma vez que muitas fábricas foram instaladas no próprio meio rural.

Essa articulação sui generis da agricultura familiar com o mercado de trabalho de atividades não-agrícolas trouxe novas perspectivas de reprodução social e econômica para as famílias rurais dessas regiões. Ao invés do clássico mecanismo de proletarização e abandono do campo e dos estabelecimentos agrícolas, o que se verifica nessas áreas é, pelo contrário, uma revitalização do espaço rural, que se dá através da permanência das famílias nas propriedades, pela formação de famílias jovens e construção de suas novas moradias na propriedade paterna, pela expansão do comércio e das atividades de prestação de serviços, entre outros impactos. As famílias rurais organizam-se de modo a que uma parte de seus membros permaneça na propriedade (geralmente os pais, as crianças ou, simplesmente, os mais velhos), enquanto os demais integrantes da família dedicam-se aos trabalhos fora da propriedade. Mesmo trabalhando externamente à propriedade, a grande maioria desses trabalhadores permanece residindo no meio rural e mantendo a propriedade parcialmente produtiva, com o intuito de garantir, primordialmente, a produção alimentar para a subsistência.

Esse fenômeno ocorre tanto no Rio Grande do Sul quanto em Santa Catarina. No período recente, foi através do recurso às atividades não-agrícolas que os agricultores familiares de ambas as regiões vislumbraram novas estratégias de reprodução social. Essa mudança, no entanto, afetou diretamente os processos produtivos e a forma de organização do trabalho familiar, uma vez que boa parte dos membros em idade plena para trabalhar ocupam a maior parte de seu tempo em atividades que não estão ligadas ao cultivo da terra.

Essa descrição fornece um quadro sintético das transformações sociais e econômicas que ocorrem em algumas regiões gaúchas e catarinenses, nas duas últimas décadas. São unidades agrícolas familiares que, através da inserção de parte de seus membros no mercado de trabalho não-agrícola, garantem não somente sua sobrevivência econômica, mas alcançam razoáveis índices de bem-estar social, garantindo a reprodução social dos membros que integram essas unidades. 


\subsection{ADINÂMICALOCALDAPLURIATIVIDADE: PADREETERNOILGES/RS EVILAITOUPAVA/SC}

Para melhor compreender a natureza e as especificidades desses novos processos de reprodução social dos agricultores, via ampliação da pluriatividade nas unidades familiares, é que foram realizados dois estudos de caso, um no Rio Grande do Sul e o outro em Santa Catarina. O principal objetivo deste trabalho é demonstrar as razões que levaram à emergência desse novo formato organizacional, bem como analisar a conformação dessa nova forma de organização do trabalho e da produção das unidades agrícolas familiares. Desse modo, pretende-se investigar os efeitos das alterações dos fatores produtivos, particularmente o uso e a alocação da força de trabalho familiar e o processo produtivo, provocados pela pluriatividade.

A opção pelo estudo da agricultura familiar e pluriatividade no Rio Grande do Sul e em Santa Catarina foi especialmente motivada pelo desafio de alargar o conhecimento sobre tais temas em região mais abrangente, ampliando a possibilidade de generalização e universalidade dos resultados. Mas a opção pela inclusão da região do Vale do Itajaí também está relacionada ao desejo de estudar uma região e uma realidade social muito semelhante àquela investigada em trabalho anterior (Schneider, 1994). Essas semelhanças estão relacionadas à história da colonização alemã, pois ambas as regiões, no Rio Grande do Sul e em Santa Catarina, foram pioneiras na recepção de imigrantes de origem européia, ainda que em períodos diferentes (no primeiro caso, a colonização iniciou-se em 1824 e, em Santa Catarina, ocorreu a partir de 1850, com a fundação de Blumenau). Em ambas as regiões, o processo de ocupação de áreas e a forma de acesso e tamanho das propriedades estimularam a formação de sociedades com características muito parecidas. Além da semelhança da estrutura de ocupação fundiária, baseada nas pequenas propriedades, raramente superiores a 50 hectares, as populações dessas duas regiões têm em comum a língua (embora sejam dialetos diferentes), a etnia, a cultura, os hábitos alimentares e a forma de organização sócio-econômica. Em razão disso, conforme mostram outros estudos (Seyferth, 1974; Roche, 1969, e, mais recentemente, Schneider, 1999; Raud, 1999), a trajetória da evolução econômica e social dessas sociedades também registra fortes similitudes, que não precisam ser retomadas.

Importa mencionar, contudo, que o desafio de enfrentar uma "nova área de estudos", ainda que muito semelhante àquela já analisada no Rio Grande do Sul, integra uma concepção do ofício do sociólogo que sustenta a necessidade de ruptura com o "paroquialismo" e a busca do "estranhamento" do pes- 
quisador perante seu objeto de estudo para melhor conhecê-lo.Além disso, a partir da consulta aos estudos de Anjos (1995) e Seyferth (1987), reconheceuse que a realidade do Vale do Itajaí revelava ser, de fato, uma situação social e econômica com características estruturais muito semelhantes ao caso gaúcho estudado (Schneider, 1994). Com base nessas informações, imaginava-se que a comparação de ambos os casos poderia evidenciar um fenômeno mais amplo e, portanto, de relevância social mais importante. Não se deve desconhecer que, no início da presente década, propor a discussão sobre pluriatividade ou agricultura em tempo parcial no Brasil soava estranho até mesmo para os estudiosos agrários mais respeitados. Assim, ao se incluir a região do Vale do Itajaí na presente pesquisa, a expectativa foi que tal agregação pudesse conferir respaldo social e trazer legitimidade acadêmica a um tema quase ignorado ou, pelo menos, ainda muito pouco estudado no país.

O mapa a seguir indica a localização dos Estados de Santa Catarina e do Rio Grande do Sul, as regiões abrangidas pelos estudos de caso e os municípios de Blumenau, onde se situa a localidade de Braço do Sul, e Santa Maria do Herval, onde se situa a localidade de Padre Eterno Ilges, onde foi realizada a pesquisa de campo.

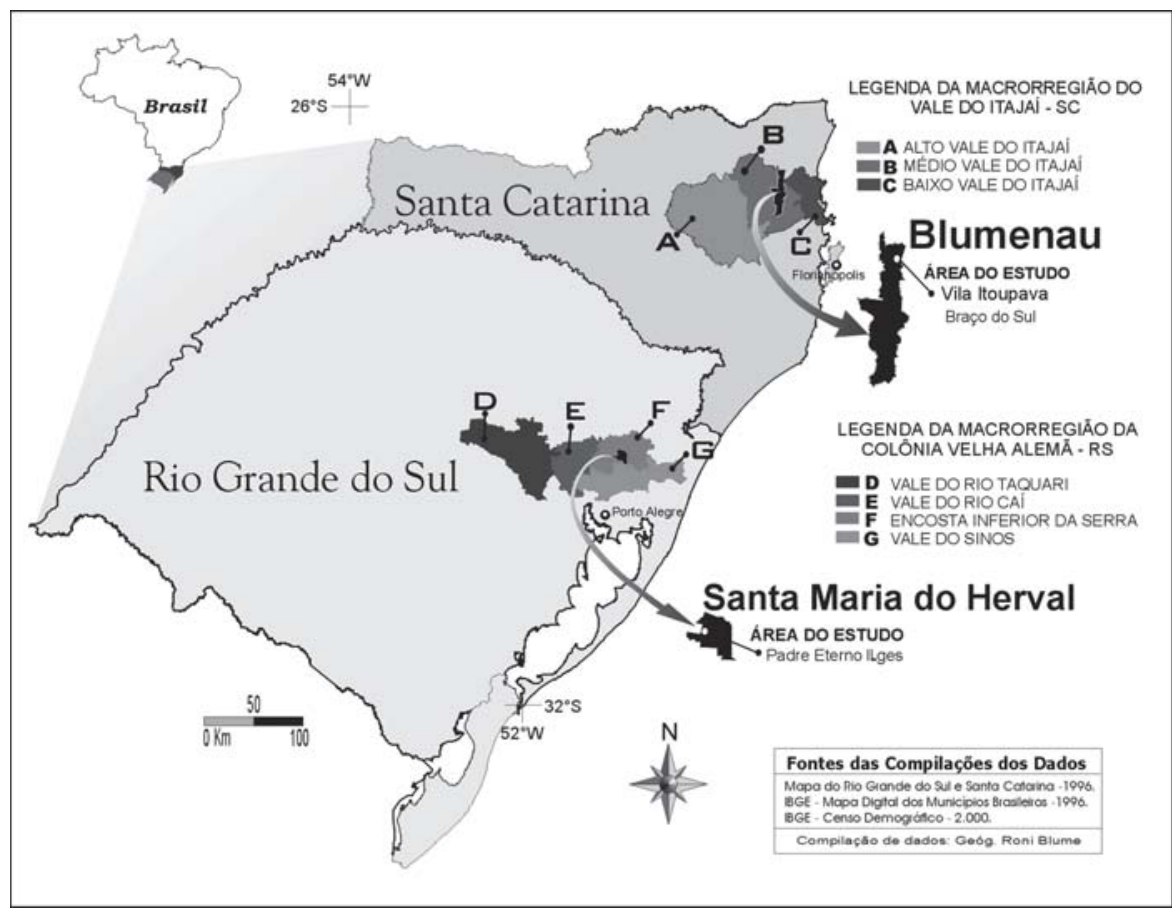


O município de Santa Maria do Herval emancipou-se de Dois Irmãos no ano de 1988 e localiza-se na Encosta Inferior da Serra do Nordeste, com uma área de $157 \mathrm{~km}^{2}$, sendo $121,52 \mathrm{~km}^{2}$ de zona rural. Em seu conjunto, o município guarda semelhança com o distrito catarinense de Vila Itoupava, pois sua população, em 1996, era de 5.482 habitantes, sendo 2.123 moradores na área urbana e 3.359 nas comunidades rurais (2.859 homens e 2.623 mulheres). Em 2000, a população total passou para 5.888, sendo 29,4\% residentes na área rural.Em 1991, havia no município 10 indústrias, que empregavam 888 trabalhadores. A localidade de Padre Eterno Ilges dista em torno de cinco quilômetros da sede de Santa Maria do Herval e está situada na parte leste do município, próximo à divisa com o município de Igrejinha. Nesta localidade também há uma indústria de calçados e várias outras atividades não-agrícolas são desenvolvidas.

A localidade de Braço do Sul, situada no distrito Vila Itoupava fica ao norte do município de Blumenau, na divisa com Massaranduba, a $25 \mathrm{~km}$ de distância do centro urbano da cidade. $\mathrm{O}$ distrito de Vila Itoupava foi criado em 1943, com uma área de $91 \mathrm{~km}^{2}$, sendo $7 \mathrm{~km}^{2}$ de área urbana e $84 \mathrm{~km}^{2}$ de zona rural. Vila Itoupava caracteriza-se por ser uma área de colonização alemã, que ainda mantém fortes e vivas as tradições germânicas (língua, festas, prática do tiro ao alvo, comida típica, músicas, etc.). Segundo Farfán (1991), a taxa de crescimento demográfico do distrito tem-se mantido praticamente estável nos últimos trinta anos, pois em 1960 havia 3.012 habitantes, em 1970, 3.492 e, em 1980, 3.990. Em 1991, a população de Vila Itoupava era estimada em 4.460 habitantes (2.273 homens e 2.187 mulheres), sendo 3.433 $(69,6 \%)$ na zona rural e 1.027 na área urbana $(30,4 \%)$.A grande maioria dos moradores é formada por descendentes de alemães $(92,2 \%)$, predominando as jovens (42,1\% em 1991) com menos de 20 anos de idade.

Em Vila Itoupava existem mais de 600 estabelecimentos rurais, que são explorados com base no trabalho da família que, segundo Farfán, se dedica basicamente à produção de subsistência. A estrutura ocupacional do distrito está fortemente assentada sobre os empregos na indústria, que absorve $1.081(71,8 \%)$ empregados, seguido dos serviços que conta com 201 $(13,3 \%)$, dos autônomos com $170(11,3 \%)$ e do comércio com $54(3,6 \%)$. A localidade é largamente dependente dos empregos oferecidos pela empresa HACO, uma fábrica de têxteis, etiquetas e bordados fundada no local em 1928. Segundo Farfán (1991, p.7), essa indústria emprega 1.031 funcionários, sendo 858 residentes em Vila Itoupava, o que o levou a afirmar que "[...] é evidente que a vida dos moradores da Vila gira em torno da fábrica" (que, segundo seus proprietários, é a maior fabricante mundial de etiquetas). Em 1991, havia em Vila Itoupava 868 domicílios, sendo 786 próprios $(90,6 \%), 45$ alugados $(5,2 \%)$ e 29 cedidos $(3,3 \%)$. 


\subsection{OESTUDODAPLURIATIVIDADE EM PERSPECTIVACOMPARADA}

Frente às semelhanças e diferenças entre as áreas onde ocorre a pluriatividade, o recurso ao método comparativo apresentou-se como a ferramenta analítica adequada ao tipo de investigação sociológica pretendida. Considera-se que a comparação, enquanto momento da atividade cognitiva, pode ser considerada como inerente ao processo de construção do conhecimento nas Ciências Sociais. O modo comparativo de proceder e apreender mentalmente a realidade permite descobrir regularidades, perceber deslocamentos e transformações, construir modelos e tipologias, identificando continuidades e descontinuidades, semelhanças e diferenças, e explicitando as características gerais que regem os fenômenos sociais.

Para alguns autores, a impossibilidade de aplicar o método experimental às Ciências Sociais, reproduzindo, experimentalmente, os fenômenos estudados, faz com que a comparação torne-se um requisito fundamental em termos de objetividade científica (Schneider e Schmitt, 1998). É ela que nos permite romper com a singularidade dos eventos, formulando leis capazes de explicar o social. Nesse sentido, a comparação aparece como inerente a qualquer pesquisa no campo das Ciências Sociais, esteja ela direcionada para a compreensão de um evento singular ou voltada para o estudo de uma série de casos previamente escolhidos. A estratégia comparativa adotada na análise dos dois casos procurou combinar a comparação de casos, de tipo weberiana, com a comparação de variáveis-chave, tal como sugerido por Ragin e Zaret (1983). ${ }^{67}$

O procedimento metodológico inicialmente adotado foram visitas às áreas escolhidas. No Rio Grande do Sul, o levantamento de dados na região da Encosta Inferior da Serra foi facilitado devido à familiaridade do autor com a área e ao fato do estudo ser, de fato, uma continuidade de trabalhos anteriores (Schneider, 1999; 1994). Em Santa Catarina, delimitouse a região do Médio Vale do Itajaí como área de concentração do trabalho de campo, tendo em vista as pesquisas sobre as transformações da agricultura familiar que já haviam sido realizadas por Seyferth $(1984,1992)$ e, mais recentemente, por Anjos (1995).

No Rio Grande do Sul, a trajetória da escolha da localidade de Padre Eterno Ilges, situada no município de Santa Maria do Herval, já havia sido realizada desde o ano de 1996. Contribuíram para a escolha dessa localidade os contatos pessoais e o conhecimento pessoal da região, tendo em

\footnotetext{
${ }^{67}$ Para uma discussão sobre a utilização do método comparativo em Ciências Sociais, consultar Schneider e Schmitt (1998).
} 
vista o estudo conduzido anteriormente (Schneider, 1994).Em Santa Catarina escolheu-se uma pequena localidade, chamada Braço do Sul, situada no distrito de Vila Itoupava, município de Blumenau. Esse distritoé vizinho ao município de Massaranduba e, segundo informações obtidas na Prefeitura, constituise na área "mais rural" do município. A escolha dessa localidade ocorreu após um período de três dias de visitas à região do Médio Vale do Itajaí, nos quais foram percorridas várias comunidades cujas características sociais e econômicas eram muito semelhantes às verificadas em Braço do Sul.

Finalizada essa primeira fase, de conhecer o universo ou a população a ser pesquisada, obteve-se os seguintes indicadores em relação às localidades de Padre Eterno Ilges e Braço do Sul: ${ }^{68}$

Tabela 7

NÚMERO TOTAL DE ESTABELECIMENTOS E FAMÍLIAS NAS LOCALIDADES DEPADREETERNO ILGES (RS) E BRAÇODO SUL (SC)

\begin{tabular}{|c|c|c|c|c|}
\hline \multirow[t]{2}{*}{ População/Universo total } & \multicolumn{2}{|c|}{$\begin{array}{c}\text { RIO GRANDE } \\
\text { DO SUL } \\
\text { Padre Eterno Ilges }\end{array}$} & \multicolumn{2}{|c|}{$\begin{array}{c}\text { SANTA CATARINA } \\
\text { Vila Itoupava - } \\
\text { Braço do Sul }\end{array}$} \\
\hline & Total & $\%$ & Total & $\%$ \\
\hline $\begin{array}{l}\text { Número total de famílias e/ou } \\
\text { estabelecimentos da localidade }\end{array}$ & 78 & 100 & 185 & 100 \\
\hline Famílias pluriativas & 44 & 56,5 & 77 & 41,6 \\
\hline Famílias de agricultores & 21 & 26,9 & 42 & 22,7 \\
\hline $\begin{array}{l}\text { Famílias que moram no meio } \\
\text { rural mas não possuem nenhuma } \\
\text { atividade agrícola }\end{array}$ & - & - & 63 & 34 \\
\hline Proprietários absenteístas & 9 & 11,5 & 3 & 1,7 \\
\hline Sítios de lazer & 4 & 5,1 & - & - \\
\hline
\end{tabular}

${ }^{68}$ É preciso ressaltar que, tanto no Rio Grande do Sul como em Santa Catarina, pôde-se contar com a generosa e valorosíssima contribuição de pessoas que conheciam em detalhes todos os moradores das localidades escolhidas. No município de Santa Maria do Herval encontramos o senhor Rodrigo Fritzen, que além de agricultor é radialista, que forneceu uma listagem dos nomes das famílias e informações sobre suas atividades e fontes de renda, suficientes o bastante para definirmos sua condição de pluriativas ou não. Da mesma maneira, em Blumenau recorremos a intendente do distrito de Vila Itoupava, senhora Rosamélia Laffin, que mediante consulta aos funcionários locais, providenciou uma listagem de todas as famílias que habitavam na localidade de Braço do Sul. 
A partir das informações obtidas, foi possível identificar as famílias nas quais havia membros que trabalhavam em atividades não-agrícolas e aquelas que não praticavam nenhum tipo de agricultura, conforme indicado no quadro anterior. Para efeito de composição da amostra, não foram consideradas aquelas famílias que não tinham propriedade e que moravam em um pequeno terreno. Essas famílias são numericamente expressivas no caso catarinense (34\% do total) e compõem uma nova categoria de moradores do meio rural que já não possui ligação com a agricultura (exceto em casos muito específicos, em que algumas dessas famílias residem nas proximidades da propriedade da família), razão pela qual não foram classificadas como famílias pluriativas. Os terrenos dessas famílias, em geral, são adquiridos dos agricultores locais ou até mesmo obtidos por doação, no caso de ocorrer relações de parentesco (em geral, os filhos). As atividades econômicas dessas famílias são exclusivamente os empregos não-agrícolas. Também não foram incorporados ao universo os proprietários absenteístas, referindo-se às "chácaras de fim de semana" ou até mesmo as propriedades abandonadas pelos seus proprietários.

De posse dessas informações, estabeleceu-se uma amostra aleatória simples baseada em duas variáveis-chave: o número de famílias ou estabelecimentos existentes na localidade e a presença de pessoas, nessas famílias, que desempenham algum tipo de atividade não-agrícola. Estipulouse o tamanho da amostra em $30 \%$ sobre o número total de famílias e/ou estabelecimentos definidos como famílias pluriativas e famílias de agricultores, obtendo-se as amostras indicadas na Tabela 8. Portanto, a pesquisa de campo operou com uma amostragem por estabelecimentos e famílias.

\section{Tabela 8}

AMOSTRADE FAMÍLIAS DEAGRICULTORES E PLURIATIVAS UTILIZADAS NAPESQUISA DECAMPO NAS LOCALIDADES DEPADREETERNOILGES (RS) EBRAÇO DO SUL (SC)

\begin{tabular}{|l|c|c|c|c|}
\hline \multirow{2}{*}{ AMOSTRA } & \multicolumn{2}{|c|}{$\begin{array}{c}\text { RIO GRANDE } \\
\text { DO SUL } \\
\text { Padre Eterno Ilges }\end{array}$} & \multicolumn{2}{c|}{$\begin{array}{c}\text { SANTA CATARINA } \\
\text { Vila Itoupava - } \\
\text { Braço do Sul }\end{array}$} \\
\cline { 2 - 5 } & $\mathrm{N}^{\circ}$ & $\%$ & $\mathrm{~N}^{\circ}$ & $\%$ \\
\hline $\begin{array}{l}\text { Número total de famílias e/ou } \\
\text { estabelecimentos da localidade }\end{array}$ & 78 & 100 & 185 & 100 \\
\hline Famílias pluriativas & 13 & 29,5 & 24 & 31,16 \\
\hline Famílias de agricultores & 10 & 47,61 & 13 & 30,9 \\
\hline Indivíduos pluriativos & 13 & - & 15 & - \\
\hline
\end{tabular}


Na localidade de Padre Eterno Ilges, no município gaúcho de Santa Maria do Herval, havia um total de 78 estabelecimentos, nos quais residiam 36 pessoas que pertenciam a famílias de agricultores e 69 pessoas que pertenciam a famílias pluriativas. Desses 78 estabelecimentos, conforme indica o quadro anterior, foram selecionadas 10 famílias de agricultores e 13 famílias pluriativas para compor a amostra do Rio Grande do Sul. Na localidade de Braço do Sul, na região do Médio Vale do Itajaí, havia 185 estabelecimentos, nos quais habitavam também 36 pessoas pertencentes a famílias de agricultores e 115 pessoas a famílias pluriativas. Desses 185 estabelecimentos selecionaram-se 13 famílias de agricultores e 24 de pluriativos, compondo assim a amostra de Santa Catarina. Além dessas famílias, com as quais foram aplicados os questionários estruturados, nas famílias pluriativas também foram selecionados os indivíduos que efetivamente exerciam alguma atividade não-agrícola, sendo escolhidos 13 no Rio Grande do Sul (portanto, um em cada família pluriativa, devido ao pequeno tamanho da amostra) e 15 em Santa Catarina. A amostra final, portanto, foi constituída de 60 estabelecimentos, sendo 23 no Rio Grande do Sul e 37 em Santa Catarina, onde habitavam 256 pessoas, sendo 72 pertencentes a famílias de agricultores e 184 a famílias de pluriativos.

\subsection{PARA UMA DEFINIÇÃO OPERACIONAL DAPLURIATIVIDADE}

Antes de aplicar os questionários foi necessário conhecer, do modo mais fidedigno possível, as características e a estrutura social e econômica da comunidade escolhida. Segundo Barbetta (1994), a estratégia de determinar a população-alvo de uma pesquisa a partir da consulta prévia aos atores envolvidos aproxima-se daquilo que os estatísticos definem como amostra proposital ou por julgamento.

Para determinar a população-alvo ou o universo da pesquisa recorreu-se a entrevistas informais com técnicos extensionistas, líderes comunitários, professores, representantes do poder público e religiosos. No Rio Grande do Sul, também se contou com o censo municipal realizado pela Prefeitura de Santa Maria do Herval, em 1991, que recolheu detalhadas informações sobre a localidade distrital de Padre Eterno Ilges. Já em Santa Catarina, pôde-se contar com as informações (de excelente qualidade) sobre a realidade do distrito de Vila Itoupava, obtidas no diagnóstico socioeconômico encomendado pela Prefeitura de Blumenau ao Departamento de Estudos Sócio-Econômicos Rurais (DESER), realizado no ano de 1997.

Nessa fase, a tarefa mais desafiadora foi determinar quais as características de uma família pluriativa. Segundo a definição adotada, famílias plu- 
riativas são aquelas em que algum dos membros que compõem o núcleo familiar exerce um tipo de atividade considerada não-agrícola. A distinção entre famílias pluriativas e famílias de agricultores (portanto não-pluriativas) está assentada sobre o tipo de atividade que exercem os indivíduos membros das famílias rurais. Assim, será considerada pluriativa aquela família em que pelo menos um de seus membros estiver ocupado em atividade estranha à agricultura. Em razão da grande variedade de atividades existentes no meio rural, a distinção entre o que é agrícola e não-agrícola muitas vezes é tênue e/ou controvertida. No entanto, para efeito deste trabalho, considera-se atividades não-agrícolas aquelas tarefas que não implicam o envolvimento direto nos processos de produção vegetal e/ou animal.

Nos casos concretos deste estudo, as atividades não-agrícolas formam uma gama variada de tarefas e ocupações, predominando as atividades assalariadas fora da propriedade ligadas aos setores têxtil, em Santa Catarina, e ao setor coureiro-calçadista, no Rio Grande do Sul. Essas atividades podem ser desempenhadas dentro ou fora do estabelecimento rural. No caso de ser dentro da propriedade, como é o caso do beneficiamento ou processamento de produtos agrícolas in natura (a chamada agregação de valor a um determinado produto), essas atividades também podem ser chamadas de "para-agrícolas", tal como sugerido no estudo do Arkleton Trust (1992). Assim, a título ilustrativo, um agricultor que beneficia sua produção de ervamate e a vende em pacotes avulsos, ou então famílias rurais que produzem doces coloniais ou derivados de leite, como o queijo, serão consideradas pluriativas. É preciso admitir, no entanto, que há uma difusa linha que separa o que é ou não um agricultor pluriativo, quando se trata das atividades não-agrícolas executadas dentro da propriedade. O mesmo critério foi utilizado para definir as atividades não-agrícolas desempenhadas fora da propriedade. Ou seja, foram consideradas atividades não-agrícolas aquelas tarefas que não implicam a participação direta nos processos produtivos agropecuários. Assim, por exemplo, o trabalho temporário típico como o envolvimento sazonal na colheita, a limpeza, o plantio, etc.; não foi considerado atividade não-agrícola, até porque isso implicaria classificar todos os "bóias-fria" e "volantes" como pluriativos, o que não faz sentido.

Além da qualificação das atividades há o desafio classificatório das rendas. O que são rendas não-agrícolas? Nos casos aqui investigados, as rendas não-agrícolas são aquelas que correspondem à remuneração auferida com a execução das atividades anteriormente definidas. A exceção deve ser feita em relação aos recursos advindos das aposentadorias ou das transferências sociais, quer sejam elas rurais ou urbanas. Nesse caso, as rendas advindas dessas fontes não serão somadas à renda agrícola e tampouco à renda nãoagrícola de uma família qualquer. As receitas ou entradas oriundas de aposen- 
tadorias ou transferências serão computadas à parte. Assim, se em uma família qualquer houver um indivíduo (em geral os avós) que receba uma aposentaria rural ou outro tipo de receita de transferências sociais (benefício a título de invalidez, por exemplo) isso não implica que essa família seja considerada pluriativa. O que define a família pluriativa é, em primeiro lugar, a combinação de mais de uma atividade, sendo uma delas na agricultura, tendo em vista tratar-se de agricultores familiares pluriativos, e não de outra categoria social que eventualmente possa compartilhar mais de um tipo de ocupação (por exemplo, médico e proprietário rural, advogado e professor).

Nessa definição são considerados membros da família aqueles indivíduos que habitam em um mesmo estabelecimento (propriedade rural), mas não necessariamente sob o mesmo teto. Na ampla maioria dos casos, esses indivíduos também estão ligados por laços de consangüinidade e de parentesco, mas é possível encontrar famílias nas quais os membros que não possuem essas duas últimas características são também considerados membros da família. 


\section{CAPÍTULO5 \\ A pluriatividade como estratégia de reprodução da agricultura familiar}

Neste capítulo serão apresentados os resultados da pesquisa de campo realizada nas comunidades de Padre Eterno Ilges e Braço do Sul sobre as famílias de agricultores e famílias pluriativas. Conforme antes ressaltado, a escolha dessas duas comunidades do Rio Grande do Sul e de Santa Catarina, respectivamente, permitiu realizar um duplo processo de comparação. Por um lado, a comparação entre as famílias de agricultores com as famílias pluriativas, cujas diferenças sociais, econômicas e culturais, como se verá, são de grande significação, contribuindo para esclarecer sobre as possibilidades sociais da pluriatividade como uma tendência nas regiões agrárias do Sul do Brasil. Por outro lado, permitiu também um tipo de comparação de caráter espacial e histórico, mediante o cotejo de ambos os grupos investigados nos dois Estados.

A distribuição etária das 256 pessoas que integram as famílias de agricultores e famílias pluriativas pesquisadas é apresentada na Tabela 1, a seguir. A principal diferença entre as duas categorias situa-se na faixa etária de pessoas acima de 60 anos de idade, pois entre as famílias de agricultores há $23,6 \%$ nesta faixa e entre as famílias pluriativos somente $9,7 \%$. Nas demais faixas etárias, apesar da diferença da proporção dos que foram selecionados para a amostra, ao se verificarem os valores relativos, as diferenças não são tão significativas, embora as famílias pluriativas apresentem idade média geral menor, indicando maior proporção de pessoas na faixa de 11 a 59 anos. As famílias de agricultores, por sua vez, parecem seguir uma tendência geral das regiões coloniais do Sul, isto é, maior presença de idosos e de crianças (normalmente os netos que permanecem algum tempo morando na propriedade com os avós). 


\section{Tabela 1}

FAIXAS DE IDADE E DISTRIBUIÇÃO DOS MEMBROS DAS FAMÍLIAS

DEAGRICULTORES EPLURIATIVOS DAAMOSTRA

\begin{tabular}{|l|c|c|c|c|c|}
\hline \multirow{3}{*}{ Idade (anos) } & \multicolumn{2}{|c|}{ Total } & \multicolumn{2}{c|}{ Total } & Total da \\
& Agricultores (RS e SC) & Pluriativos (RS e SC) & Amostra \\
\cline { 2 - 6 } & $\mathrm{n}$ & $\%$ & $\mathrm{n}$ & $\%$ & $\mathrm{n}$ \\
\hline Até 10 & 17 & 23,6 & 30 & 16,3 & 47 \\
11 a 18 & 9 & 12,5 & 42 & 22,8 & 51 \\
19 a 34 & 14 & 19,5 & 36 & 19,5 & 50 \\
35 a 59 & 15 & 20,8 & 58 & 31,5 & 73 \\
60 ou mais & 17 & 23,6 & 18 & 9,7 & 35 \\
\hline Total da amostra & 72 & 100 & 184 & 100 & 256 \\
\hline
\end{tabular}

Fonte: Pesquisa de campo (1998).

No que se refere à estratificação das duas categorias analisadas, famílias de agricultores e famílias pluriativas, segundo o sexo e a idade, percebe-se, como indicado na Tabela 2 , que entre os membros do sexo masculino a principal diferença concentra-se na faixa dos que têm acima de 60 anos de idade. Os homens agricultores nesta faixa somam $21,8 \%$ ao passo que entre os pluriativos do sexo masculino esta proporção chega apenas a 9,7\%. Entre as mulheres essa diferença se repete, pois $25 \%$ das agricultoras têm 60 anos ou mais, ao passo que apenas $9,7 \%$ das mulheres de famílias pluriativas situam-se nessa faixa de idade. Entre as mulheres também se destaca a diferença nas faixas de 11 a 18 anos, na qual a proporção de pluriativas chega a $27,1 \%$ e as agricultoras apenas a $12,5 \%$, o que indica que entre as famílias pluriativas há um contingente expressivo de jovens do sexo feminino. A outra diferença está na faixa etária dos 35 aos 59 anos de idade, na qual se verifica uma maior presença de mulheres pluriativas $(31,5 \%)$ do que agricultoras $(15 \%)$.

Tabela 2

IDADE/SEXO DOS MEMBROS QUE COMPÕEM AS FAMÍLIAS

DE AGRICULTORES E PLURIATIVAS, NAS COMUNIDADES SELECIONADAS

\begin{tabular}{|l|c|c|c|c|c|c|}
\hline \multirow{2}{*}{ Idade/Sexo } & \multicolumn{3}{|c|}{ Agricultores } & \multicolumn{3}{c|}{ Pluriativos } \\
\cline { 2 - 7 } & \% Masc. & $\%$ Fem. & Total & \% Masc. & $\%$ Fem. & Total \\
\hline Até 10 & 21,8 & 25 & 17 & 15,2 & 17,3 & 30 \\
11 a 18 & 12,5 & 12,5 & 9 & 18,4 & 27,1 & 42 \\
19 a 34 & 15,6 & 22,5 & 14 & 25 & 14,1 & 36 \\
35 a 59 & 28,1 & 15 & 15 & 29,3 & 31,5 & 58 \\
60 ou mais & 21,8 & 25 & 17 & 9,7 & 9,7 & 18 \\
\hline Total & 100 & 100 & 72 & 100 & 100 & 184 \\
\hline
\end{tabular}

Fonte: Pesquisa de campo (1998). 
Além da estrutura etária e da separação por sexo das famílias de agricultores e pluriativos das regiões selecionadas, é importante verificar a quantidade de pessoas que compõem essas famílias e como se distribuem. A Tabela 3 indica a distribuição do número de membros por família investigada. Cabe lembrar que os números se referem à quantidade de famílias da amostra e a coluna ao lado apresenta a quantidade de membros que existem por família de agricultores ou de pluriativos.

Tabela 3

NÚMERO TOTAL DE FAMÍLIAS E MEMBROS POR FAMÍLIA DE AGRICULTORES E FAMÍLIA DE PLURIATIVOS NAS COMUNIDADES SELECIONADAS

\begin{tabular}{|c|c|c|c|c|c|c|c|c|c|c|c|c|}
\hline \multirow{2}{*}{$\begin{array}{c}\text { Número de } \\
\text { pessoas por } \\
\text { família }\end{array}$} & \multicolumn{4}{|c|}{$\begin{array}{l}\text { Famílias de } \\
\text { agricultores }\end{array}$} & \multicolumn{4}{|c|}{$\begin{array}{l}\text { Famílias de } \\
\text { pluriativos }\end{array}$} & \multicolumn{4}{|c|}{$\begin{array}{c}\text { Soma total de indivíduos } \\
\text { e famílias }\end{array}$} \\
\hline & \multicolumn{2}{|c|}{ RS } & \multicolumn{2}{|r|}{$\mathrm{SC}$} & \multicolumn{2}{|r|}{ RS } & \multicolumn{2}{|c|}{ SC } & \multicolumn{2}{|c|}{ Agricultores } & \multicolumn{2}{|c|}{\begin{tabular}{|l} 
Pluriativos \\
\end{tabular}} \\
\hline & Fam & Memb & Fam & Memb & Fam & Memb & Fam & Memb & Fam & Memb & Fam & Memb \\
\hline $\begin{array}{l}\text { Somente } 1 \\
\text { pessoa }\end{array}$ & 1 & 1 & 2 & 2 & - & - & - & 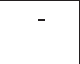 & 3 & 3 & & \\
\hline 2 pessoas & 3 & 6 & 7 & 14 & - & - & 2 & 4 & 10 & 20 & 2 & 4 \\
\hline 3 pessoas & 1 & 3 & - & & - & - & 3 & 9 & 1 & 3 & 3 & 9 \\
\hline 4 pessoas & 3 & 12 & 2 & 8 & 3 & 12 & 5 & 20 & 5 & 20 & 8 & 32 \\
\hline 5 pessoas & 1 & 5 & 1 & 5 & 5 & 24 & 7 & 35 & 2 & 10 & 12 & 59 \\
\hline 6 pessoas & - & - & 1 & 6 & 4 & 24 & 4 & 24 & 1 & 6 & 8 & 48 \\
\hline 7 pessoas & - & - & - & 1 & - & - & 2 & 14 & - & - & 2 & 14 \\
\hline 8 pessoas & - & & - & . & - & 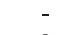 & - & - & - & - & - & - \\
\hline 9 pessoas & 1 & 9 & - & - & 1 & 9 & 1 & 9 & 1 & 9 & 2 & 18 \\
\hline Total & 10 & 36 & 13 & 36 & 13 & 69 & 24 & 115 & 23 & 72 & 37 & 184 \\
\hline
\end{tabular}

Fonte: Pesquisa de campo (1998).

A primeira consideração é que do total das 60 famílias investigadas, perfazendo 256 membros individuais, somente três famílias eram compostas por apenas um membro. Trata-se de famílias de agricultores viúvos. Outra informação que pode ser extraída desta tabela, reafirmando as hipóteses da Tabela 2, é que as famílias de agricultores são compostas por apenas 72 indivíduos, enquanto as famílias de pluriativos chegam a 184 membros. Das 23 famílias entrevistadas, 13 (ou seja, 56\%) tinham até dois membros e somente 4 (ou 17\%), mais de cinco membros. Já as famílias pluriativas, ao contrário, acusaram uma quantidade expressiva de unidades compostas por cinco pessoas ou mais (65\% ou 24 das 37 famílias entrevistadas) ${ }^{69}$ No Rio Grande do Sul, essa proporção alcança 77\% das famílias de pluriativos e, em Santa Catarina, chega a 58\%.

${ }^{69}$ A média geral de pessoas por família é de 4,2 nas duas localidades pesquisadas. Esse resultado advém da divisão do total dos membros das famílias de agricultores e pluriativos (72 e 184, respectivamente, vide Tabela 2), 256 pessoas, pelo número de famílias selecionadas, 60 no conjunto. 
A partir dessas informações, depreende-se, portanto, que as famílias de agricultores, por terem maior proporção de membros com idades superiores a 60 anos ( $23,6 \%$ contra 9,7\% de pluriativos) e serem compostas por uma quantidade menor membros, são também menos aptas a deslocar parte de sua força de trabalho para fora da unidade produtiva, pela simples razão de que, havendo pouca disponibilidade de "braços",é de se esperar que sejam recrutados inteiramente para as tarefas da propriedade. A variável demográfica, nesse caso, constitui-se em importante elemento de diferenciação entre unidades familiares, sendo notório que favorece o desenvolvimento da pluriatividade naquelas em que houver mais disponibilidade de membros.

A comparação das variáveis idade e número de indivíduos por unidade permite postular, portanto, a hipótese de uma correlação direta entre o tamanho da família e o recurso à pluriatividade. Para testar essa hipótese e ampliar a caracterização etária e demográfica das famílias investigadas, realizou-se outro tipo de averiguação, buscando associar essas duas variáveis com a posição dos membros na hierarquia familiar, classificados segundo sua condição de chefe, cônjuge, filho ou outros.

A Tabela 4 apresenta, especificamente, as famílias de agricultores, nos dois casos estudados, Padre Eterno Ilges e Braço do Sul. Conforme podese notar, nessas famílias os chefes representam algo em torno de $30 \%$ em relação às demais posições da família e, somados aos cônjuges, essas duas posições representam em torno de $50 \%$ dos integrantes das famílias do subgrupo de agricultores. Na maioria dessas famílias a posição de chefe do estabelecimento é ocupada por pessoas do sexo masculino (47,1\% no Rio Grande do Sul e 53,3\% em Santa Catarina). Mesmo assim, a posição de filho ainda continua sendo aquela que concentra maior proporção $(47,2 \%$ no RS e $36,1 \%$ em SC) de indivíduos.

Tabela 4 POSIÇÃONAFAMÍLIAE SEXODOS AGRICULTORES, NAS COMUNIDADES SELECIONADAS

\begin{tabular}{|l|c|c|c|c|cc|}
\hline \multirow{2}{*}{ Posição } & \multicolumn{4}{|c|}{ Sexo } & \multirow{2}{*}{ Total } \\
\cline { 2 - 6 } & Masculino & Feminino & \multicolumn{2}{|c}{} \\
\cline { 2 - 6 } & RS & SC & RS & SC & RS & SC \\
\hline Chefe & 47,1 & 53,3 & 10,5 & 23,8 & 27,8 & 36,1 \\
Cônjuge & & & 42,1 & 28,6 & 22,2 & 16,7 \\
Filhos & 52,9 & 26,7 & 42,1 & 42,9 & 47,2 & 36,1 \\
Outro & & 20,0 & 5,3 & 4,8 & 2,8 & 11,1 \\
\hline Total & 100,0 & 100,0 & 100,0 & 100,0 & 100,0 & 100,0 \\
\hline
\end{tabular}

Fonte: Pesquisa de campo (1998). 
Há ainda dois aspectos complementares que merecem ser apreciados. $\mathrm{O}$ primeiro refere-se à maior presença de chefes do sexo feminino no caso catarinense $(23,8 \%)$ frente ao gaúcho $(10,5 \%)$. Essa diferença está relacionada com a condição de viuvez das mulheres que respondem pela chefia da propriedade, sendo muito freqüente a residência de um casal de jovens na mesma casa ou em residência próxima. No caso de Padre Eterno Ilges, no Rio Grande do Sul, em quase todas as famílias selecionadas foram encontrados ambos membros do casal. O segundo aspecto refere-se à diferença, também verificada apenas em Braço do Sul, entre a proporção daqueles membros masculinos que ocupavam a posição de outros $(20 \%) \mathrm{em}$ relação às mulheres, de apenas 4,8\%. Na maioria dos casos encontrados, esses outros eram parentes das famílias do sexo masculino que moravam na mesma unidade.

Entre as famílias pluriativas, a distribuição dos membros segundo a posição que ocupam na hierarquia familiar, conforme é indicado na Tabela 5, é bastante diferente em relação aos agricultores. Em Padre Eterno Ilges, no Rio Grande do Sul, apenas 18,8\% de todos os membros das famílias pluriativas são chefes e, em Santa Catarina, apenas 20,9\% ocupam essa posição. No entanto, a maioria daqueles que são chefes pertencem ao sexo masculino (em torno de $40 \%$ nos dois casos). Ratificando a hipótese antes mencionada, entre os pluriativos há uma quantidade significativamente maior de pessoas que se encontram na posição de filhos, tanto membros do sexo masculino como feminino (com um total médio de 58\% no Rio Grande do Sul e 48,7\% em Santa Catarina) atestando, uma vez mais, a explicação de que as famílias pluriativas são formadas por uma parcela maior de jovens do que as de agricultores, o que passa a ser um elemento decisivo favorável à decisão de combinar várias inserções socioprofissionais.

\section{Tabela 5 \\ POSIÇÃO NAFAMÍLIAE SEXODOS PLURIATIVOS NAS COMUNIDADES SELECIONADAS}

\begin{tabular}{|l|c|c|c|c|cc|}
\hline \multirow{2}{*}{ Posição/Sexo } & \multicolumn{2}{|c|}{ Masculino (\%) } & \multicolumn{2}{|c|}{ Fogminino (\%) } & \multicolumn{2}{c|}{ Total (\%) } \\
\cline { 2 - 7 } & RS & SC & RS & SC & RS & SC \\
\hline Chefe & 38,2 & 39,7 & - & 1,8 & 18,8 & 20,9 \\
Cônjuge & - & - & 34,3 & 36,8 & 17,4 & 18,3 \\
Filhos & 58,8 & 48,3 & 57,1 & 49,1 & 58,0 & 48,7 \\
Outros & 2,9 & 12,1 & 8,6 & 12,3 & 5,8 & 12,2 \\
\hline Total & 100,0 & 100,0 & 100,0 & 100,0 & 100,0 & 100,0 \\
\hline
\end{tabular}

Fonte: Pesquisa de campo (1998). 
Outro indicador importante para a caracterização das famílias de agricultores e famílias pluriativas gaúchas e catarinenses é o nível de escolaridade. Em ambos os casos não foram encontradas famílias cujos membros nunca haviam freqüentado a escola. ${ }^{70}$ Os dados da pesquisa de campo revelaram, conforme consta na Tabela 6 , que tanto entre as famílias de agricultores como de pluriativos, a maior parcela frequientou a escola apenas por poucos anos, em geral até a $4^{\mathrm{a}}$ série do ensino básico. Foram poucos os membros das famílias de agricultores e pluriativos gaúchos e catarinenses que chegaram a cursar o nível chamado de segundo grau (atualmente denominado nível médio). Uma das razões que talvez explique os baixos níveis de escolarização está relacionada ao fato de serem comunidades situadas em áreas rurais afastadas dos núcleos urbanos, nas quais situam-se as escolas de primeiro e segundo graus completos. ${ }^{71}$

Tabela 6

ESCOLARIDADE DOS MEMBROS DAS FAMÍLIAS DE AGRICULTORES E PLURIATIVOS, NAS COMUNIDADES SELECIONADAS.

\begin{tabular}{|l|cc|cc|}
\hline \multirow{2}{*}{ Escolaridade } & \multicolumn{3}{|c|}{ Agricultores (\%) } & \multicolumn{2}{|}{ Pluriativos (\%) } \\
\cline { 2 - 3 } & RS & SC & RS & SC \\
\cline { 2 - 3 } $1^{\circ}$ grau incompleto & 75,0 & 86,1 & 87,0 & 85,2 \\
$1^{\circ}$ grau completo & - & 2,8 & 1,4 & 4,3 \\
$2^{\text {o }}$ grau incompleto & - & - & 1,4 & 0,9 \\
$2^{\circ}$ grau completo & 2,8 & - & 4,3 & 0,9 \\
$3^{\text {o }}$ grau completo & - & - & 1,4 & - \\
Sem idade escolar & 19,4 & 11,1 & 4,3 & 7,0 \\
Escola Especial & - & - & - & 0,9 \\
Sem resposta & 2,8 & - & - & 0,9 \\
\hline
\end{tabular}

Fonte: Pesquisa de campo (1998).

\footnotetext{
${ }^{70}$ Muitos dos idosos chegaram até mesmo a ser alfabetizados em idioma alemão, pois antes da Segunda Guerra Mundial em muitas pequenas localidades onde residiam os imigrantes alemães o ensino ainda era realizado em língua germânica. Somente após a proibição de ensinar em língua estrangeira imposta durante o governo Getúlio Vargas é que nessas localidades passou-se a ministrar aulas em português.

${ }^{71} \mathrm{~A}$ escola de $1^{\circ}$ grau completo mais próxima da localidade de Braço do Sul, em Santa Catarina, situa-se no distrito de Vila Itoupava, a uma distância de cerca de cinco quilômetros. No Rio Grande do Sul, a localidade de Padre Eterno Ilges também dista cerca de sete quilômetros da sede do Município de Santa Maria do Herval.
} 


\subsection{PLURIATIVIDADEEAGRICULTURA:ACESSO À TERRA, TRANSFORMAÇÕES NOS PROCESSOS PRODUTIVOS E IMPACTOS NA ORGGANIZAÇÃO DO TRABALHO FAMILIAR}

Um dos elementos fundamentais para se conhecer e interpretar o modo de funcionamento das unidades que operam com base no trabalho familiar, como é o caso dos agricultores e pluriativos deste estudo, é o processo produtivo. Certamente, um processo produtivo qualquer pode ser analisado a partir de diferentes enfoques, cada qual permitindo elucidar distintas dimensões. Na análise das práticas produtivas das unidades familiares gaúchas e catarinenses optou-se por uma abordagem multidimensional do processo produtivo e da propriedade, buscando caracterizar sua origem, a posse dos bens existentes no momento da pesquisa de campo e os tipos de cultivos praticados, bem como a forma de exploração econômica e as relações com o mercado. Esses quatro elementos abrangem um conjunto variado de operações técnicas, de uso de instrumentos de trabalho e alocação da força de trabalho que permitem conhecer como as famílias operacionalizam suas atividades e - o que informa diretamente este trabalho - o que singulariza as operações segundo a característica da família que as realiza.

Uma das informações essenciais refere-se à estrutura fundiária, nos dois casos. Em razão das localidades investigadas situarem-se em regiões relativamente homogêneas no que diz respeito ao tamanho das propriedades, pode-se afirmar que a estratificação de área encontrada nas localidades de Padre Eterno Ilges e Braço do Sul reproduz uma situação que se verifica em praticamente toda a região circunvizinha, tanto em um Estado como em outro. A Tabela 7 demonstra que 45,9\% das famílias pluriativas e 40,3\% das de agricultores, independente do Estado, possuem áreas não superiores a 15 hectares. Em Braço do Sul as propriedades são um pouco maiores que as gaúchas, mas, no geral, não se verificam distinções significativas entre famílias de agricultores e pluriativas. 


\section{Tabela 7}

ESTRATIFICAÇÃODE ÁREADAS PROPRIEDADESRURAIS

DEPLURIATIVOSEAGRICULTORES NASCOMUNIDADES SELECIONADAS

\begin{tabular}{|c|c|c|c|c|c|c|}
\hline \multirow{2}{*}{$\begin{array}{l}\text { Estratos de área } \\
\text { em hectares }\end{array}$} & \multicolumn{3}{|c|}{$\%$ Pluriativos } & \multicolumn{3}{|c|}{$\%$ Agricultores } \\
\hline & RS & $\mathrm{SC}$ & Total & $\mathrm{RS}$ & $\mathrm{SC}$ & Total \\
\hline---13 & 15,4 & 8,3 & 10,8 & 10,0 & 23,1 & 14,3 \\
\hline 3 |-- 5 & & 8,3 & 5,4 & 10,0 & - & 4,3 \\
\hline 5 |--- 10 & 15,4 & 12,5 & 13,5 & 10,0 & 7,7 & 8,7 \\
\hline 10 & 30,8 & 8,3 & 16,2 & 20,0 & 7,7 & 13 \\
\hline 15 & 23,1 & 12,5 & 16 & 50,0 & 15,4 & 30 \\
\hline 20 & 15,4 & 12,5 & 13 & , & 23,1 & 13,0 \\
\hline 30 & 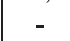 & 25,0 & 16 , & - & - & - \\
\hline $501-$ & - & - & - & & 15,4 & 8,7 \\
\hline Não-propri & - & 12,5 & 8,1 & - & 7,7 & 4,3 \\
\hline Total & 100,0 & 100,0 & 100,0 & 100 & 100 & 100,0 \\
\hline
\end{tabular}

Fonte: Pesquisa de campo (1998).

A maior parte das terras dos pluriativos e agricultores do Sul do Brasil foram obtidas através de herança, ainda que as compras de parentes e de terceiros também sejam formas importantes de acesso à terra. As informações que constam na Tabela 8 , sobre a forma de obtenção da propriedade pelas famílias de agricultores e famílias pluriativas, levam em consideração que uma mesma família pode combinar duas ou mais formas de aquisição da sua propriedade, por exemplo, ao herdar uma parte e comprar outra dos irmãos, também herdeiros, como é muito usual no meio rural. Por esta razão, torna-se impossível saber a exata proporção ou a quantidade de terra que é herdada, adquirida ou obtida através de outras formas, pois os dados apresentados refletem a soma de todas as propriedades da amostra. Como há uma variação de caso a caso, fica difícil obter informações que representem a média das proporções de área que são herdadas ou adquiridas de terceiros. Assim, as informações constantes na Tabela 8 referem-se somente à frequiência com que as famílias dos pluriativos e dos agricultores declaram ter herdado ou adquirido sua propriedade (portanto, a forma de obtenção de suas propriedades) e não em relação ao tamanho da área (obviamente, por tal razão, a soma das parcelas, na tabela, ultrapassa a 100\%). Isso permite afirmar, por exemplo, que os pluriativos de Padre Eterno Ilges obtiveram suas propriedades por herança e por compra em igual proporção (em $53,8 \%$ dos casos). Também permite dizer que $62,5 \%$ dos pluriativos de Braço do Sul obtiveram suas terras através de herança, mesmo que uma proporção também tenha adquirido parte de suas terras. Nas demais situações, o mecanismo principal de obtenção de terras foi através de herança (sobretudo, entre as famílias de agricultores). A 
utilização da rede de parentela também parece ser uma estratégia de obtenção de terras no Rio Grande do sul, onde a compra de parcelas de terras de parentes é bem mais expressiva do que em Santa Catarina.

\section{Tabela 8}

FORMA DEOBTENÇÃO DAS TERRAS DE PLURIATIVOS EAGRICULTORES NAS COMUNIDADES SELECIONADAS

\begin{tabular}{|l|cc|cc|}
\hline \multirow{2}{*}{ Forma de obtenção } & \multicolumn{3}{|c|}{ \% Pluriativos } & \multicolumn{2}{|c|}{ Agricultores } \\
\cline { 2 - 5 } & RS & SC & RS & SC \\
\hline Através de herança & 53,8 & 62,5 & 60,0 & 61,5 \\
Compra de parentes & 53,8 & 8,3 & 40,0 & 7,7 \\
Compra de terceiros & 38,5 & 25,0 & 50,0 & 23,1 \\
Através de doação & - & 8,3 & - & - \\
Posse provisória & - & - & - & 7,7 \\
Não é proprietário & - & 8,3 & - & \\
Troca & - & - & - & 7,7 \\
\hline
\end{tabular}

Fonte: Pesquisa de campo (1998).

Entretanto, se são relativamente limitadas as possibilidades de conhecer detalhadamente as formas de acesso à terra, mediante a utilização de metodologias quantitativas, no sentido de tentar identificar um padrão sucessório a partir das informações dos entrevistados sobre o modo de obtenção de sua propriedade, torna-se mister recorrer a outras técnicas de pesquisa social para cobrir essa lacuna. Nesse sentido, buscou-se maior refinamento empírico somente em relação àquelas famílias que declararam ter herdado em parte ou no todo a propriedade. Esse aprofundamento factual consiste em saber quem foi o beneficiado da herança, se o marido, a esposa ou ambos. Como se perceberá ao consultar a Tabela 9, a seguir, foi possível neste caso identificar as proporções e relacioná-las ao seu conjunto, porque se trata de uma única forma de procedimento, qual seja, uma situação em que houve herança. 


\section{Tabela 9}

FORMAS DE HERANÇAENTRE FAMÍLIAS DE AGRICULTORES EPLURIATIVAS NAS COMUNIDADES SELECIONADAS.

\begin{tabular}{|l|cc|c|cc|c|}
\hline \multirow{2}{*}{ Herdeiros } & \multicolumn{3}{|c|}{ \% Agricultores } & \multicolumn{3}{c|}{ \% Pluriativos } \\
\cline { 2 - 7 } & RS & SC & Total & RS & SC & Total \\
\hline O marido herdou a terra de sua família & 30,0 & 50,0 & 50,0 & 57,1 & 26,7 & 36,3 \\
A esposa herdou a terra de sua família & 10,0 & 12,5 & 14,3 & 28,6 & 46,7 & 40,9 \\
Ambos, marido e esposa, herdaram & 10,0 & 37,5 & 28,4 & 14,3 & 20,0 & 18,1 \\
as partes que compõe a propriedade atual & & & & & & \\
Sem resposta & 10,0 & - & 7,1 & - & 6,7 & 4,5 \\
\hline Total & 100,0 & 100,0 & 100,0 & 100,0 & 100,0 & 100,0 \\
\hline
\end{tabular}

Fonte: Pesquisa de campo (1998).

Entre as famílias de agricultores que herdaram uma parte ou toda a sua propriedade, os homens (maridos) foram os maiores beneficiados, sendo em $30 \%$ dos casos em Padre Eterno Ilges e em 50\% em Braço do Sul (em uma média de $50 \%$ quando somados os dois estados). Entre as famílias pluriativas gaúchas e catarinenses observa-se um diferença significativa. Em Padre Eterno Ilges, em 57,1\% do casos em que houve herança, foi o marido quem herdou a propriedade, mas em Braço do Sul foram as esposas que herdaram em maior proporção (46,7\%). Analisadas enquanto grupo, contudo, as esposas das famílias pluriativas herdaram propriedades em maior proporção $(40,9 \%)$ no total dos dois estados do que as esposas dos agricultores $(14,3 \%)$.

Essas informações revelam que tanto homens como mulheres, embora em proporções diferentes, são beneficiados pelos mecanismos de herança existentes nas duas regiões. Os dados revelam que o acesso à terra, elemento fundamental para constituição do patrimônio familiar, se dá tanto pela herança atribuída aos homens quanto às mulheres. Portanto, pode-se afirmar que, em ambas as regiões e tanto entre agricultores quanto entre pluriativos, vigora um aparente igualitarismo na divisão dos bens das famílias rurais. O que os dados indicam é que a expansão da pluriatividade e a "mercantilização" da vida social (para usar a expressão de Marsden) nas duas regiões elimina costumes e aponta novos padrões sucessórios. Por exemplo, o costume de atribuir a sucessão a filhos mais jovens (também chamado de "minorato"), ainda vigente em algumas regiões coloniais do sul do Brasil, parece que aos poucos desaparece em função da crescente determinação de fatores econômicos. Talvez pela mesma razão, as mulheres de famílias pluriativas tenham herdado as propriedades em maior proporção do que as mulheres do grupo dos agricultores, como apontado. Tais argumentos permitem lançar a idéia de que, em regiões agrárias, onde os processos de integração econômica avançaram, deixam de existir diferenças em relação aos mecanismos hereditários. 
$\mathrm{Na}$ ampla maioria das propriedades das famílias pluriativas e famílias de agricultores, o trabalho e a exploração da terra é realizado pelos próprios membros do núcleo doméstico. $\mathrm{O}$ arrendamento de terras para terceiros somente é realizado em Padre Eterno Ilges, tanto entre as famílias pluriativas $(23,1 \%)$ quanto entre as famílias de agricultores $(10 \%)$. Nem famílias de agricultores nem famílias pluriativas utilizam a parceria e muito raramente (à exceção do grupo catarinense) contratam trabalhadores em regime de assalariamento, conforme apontado na Tabela 10 . No entanto, há um número significativo de famílias que arrendam terras de outros para sua utilização, como é o caso das famílias pluriativas gaúchas $(23,1 \%)$ e catarinenses $(12,5 \%)$ nas comunidades investigadas. O recurso ao arrendamento de terras pelas famílias de agricultores e pluriativas de Padre Eterno Ilges pode ser atribuído à demanda por áreas maiores, sobretudo em decorrência da importância da produção florestal de acácia-negra na região do Sul do Brasil.

\section{Tabela 10}

FORMAS DE USO DATERRA,ARRENDAMENTO,PARCERIA

EASSALARIAMENTO ENTRE FAMÍLIAS PLURIATIVAS E FAMÍLIAS

DEAGRICULTORES NAS COMUNIDADES SELECIONADAS

\begin{tabular}{|c|c|c|c|c|c|c|c|c|c|}
\hline & \multicolumn{2}{|c|}{$\begin{array}{l}\text { Arrenda terras } \\
\text { próprias para } \\
\text { outros }(\%) \\
\end{array}$} & \multicolumn{2}{|c|}{$\begin{array}{c}\text { Trabalha em } \\
\text { parceria } \\
(\%)\end{array}$} & \multicolumn{2}{|c|}{$\begin{array}{l}\text { Arrenda terras de } \\
\text { outros }(\%)\end{array}$} & \multicolumn{2}{|c|}{$\begin{array}{c}\text { Contratação de } \\
\text { assalariados } \\
\text { no último ano }(\%)\end{array}$} \\
\hline & & Sim & Não & Sim & Não & Sin & Não & Sim & Não \\
\hline \multirow[t]{2}{*}{ Pluriativos } & $\mathrm{RS}$ & 23,1 & 76,9 & - & 100,0 & 23,1 & 76,9 & 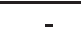 & 100,0 \\
\hline & $\mathrm{SC}$ & - & 100,0 & - & 100,0 & 12,5 & 87,5 & 12,5 & 87,5 \\
\hline \multirow[t]{2}{*}{ Agricultores } & $\mathrm{RS}$ & 10,0 & 90,0 & - & 100,0 & 10,0 & 90,0 & - & 100,0 \\
\hline & $\mathrm{SC}$ & - & 100,0 & 7,7 & 92,3 & 7,7 & 92,3 & 15,4 & 84,6 \\
\hline
\end{tabular}

Fonte: Pesquisa de campo (1998).

No que se refere à forma de utilização da superfície agrícola das terras, os dados da pesquisa de campo revelaram que há um amplo predomínio de coberturas vegetais (nas propriedades das famílias de agricultores e pluriativos), na forma de matas nativas, secundárias e áreas reflorestadas. A Tabela 11 apresenta proporções médias relativas à utilização das propriedades com os respectivos cultivos, devendo-se lembrar que essas proporções são uma média da quantidade de área que as propriedades entrevistadas usam com determinado cultivo. As áreas com matas naturais ou reflorestadas cobrem, em média, mais de $50 \%$ da superfície agrícola das terras das famílias de agricultores e pluriativas, gaúchos e catarinenses. Tais porcentagens tornam-se ainda mais significativas quando comparadas às proporções médias das matas e áreas reflorestadas com as outras formas de uso da propriedade como as lavouras e as áreas inaproveitáveis. Como 
exemplo, com base nos dados obtidos da pesquisa de campo, pode-se dizer que, em média, a superfície das propriedades de famílias pluriativas gaúchas é ocupada com 46,8\% de cobertura vegetal, $12,4 \%$ é área imprópria para uso, $15 \%$ destinase às pastagens, $11,8 \%$ é usada para horta, pomar e/ou hortifrutigrangeiros e apenas 19,7\% é ocupada com lavouras temporárias. Na região do Vale do Itajaí, onde situa-se a localidade de Braço do Sul, a proporção média de área que tanto as famílias de pluriativos como de agricultores utilizam com lavouras temporárias não chega a $10 \%$ da superfície da propriedade. Ou seja, existem poucas áreas de terra cultivadas com produtos destinados à venda, razão pela qual, como será visto mais adiante, as rendas agrícolas tendem a ser baixas.

Tabela $11^{72}$

USODATERRAENTREPLURIATIVOSEAGRICULTORES

NAS COMUNIDADES SELECIONADAS (proporções médias - em \%)

\begin{tabular}{|l|c|c|c|c:c|c|}
\hline \multirow{2}{*}{ Uso da terra } & \multicolumn{3}{|c|}{$\%$ Pluriativos } & \multicolumn{2}{c|}{$\%$ Agricultores } \\
\cline { 2 - 7 } & RS & SC & Total & RS & SC & Total \\
\hline Total lavouras temporárias & 19,7 & 8,2 & 12,6 & 18,0 & 9,5 & 13,5 \\
Total matas naturais e reflorestadas & 46,8 & 62,0 & 56,5 & 39,8 & 64,7 & 52,9 \\
Mata virgem & 5,0 & 15,0 & 12,5 & 10,2 & 13,0 & 12,1 \\
Mata secundária & 21,5 & 47,0 & 38,0 & 26,3 & 47,6 & 38,7 \\
Mata reflorestada & 25,0 & 11,1 & 17,6 & 16,3 & 11,9 & 14,5 \\
Total terra inaproveitável & 12,4 & 8,7 & 10,1 & 12,0 & 11,3 & 11,6 \\
Pastagens temporárias e perenes & 15,0 & 16,9 & 16,2 & 15,5 & 23,4 & 19,8 \\
Pastagens plantadas & 8,6 & 6,6 & 7,5 & 10,0 & 4,0 & 6,6 \\
Pastagens permanentes & 10,1 & 12,2 & 11,5 & 11,3 & 20,5 & 16,9 \\
Pomar, horta e benfeitorias & 11,8 & 14,1 & 13,4 & 21,4 & 11,1 & 15,6 \\
Pomar & 3,6 & 3,2 & 3,4 & 6,9 & 9,1 & 8,0 \\
Horta & 5,1 & 3,0 & 3,8 & 7,2 & 2,8 & 4,8 \\
Benfeitorias & 5,9 & 12,0 & 9,8 & 10,8 & 3,9 & 7,2 \\
\hline
\end{tabular}

Fonte: Pesquisa de campo (1998).

\footnotetext{
${ }^{72}$ Os valores da Tabela 11 sobre o uso da terra referem-se a uma proporção média de uso da superfície das propriedades, que é resultante da quantidade total de área ocupada com determinada cultura dividida pelo número de unidades em que é praticada. Assim, pode-se afirmar que, em média, 46,8\% da superfície das propriedades de famílias pluriativas gaúchas estava ocupada com matas e florestas plantadas. Mas isso não quer dizer, também, que todas as propriedades pesquisadas tivessem essa mesma área de terra ocupada com tal cultivo e tampouco que todos proprietários plantavam essa mesma proporção. Na verdade, essas proporções médias refletem o que seria uma média de uso da superfície em cada propriedade e, por essa razão, a soma de todos os valores médios das formas de uso da terra não perfazem $100 \%$.
} 
Chama a atenção a elevada proporção da superfície de área ocupada em matas naturais e reflorestadas com variedades nativas e exóticas aparecem como culturas importantes na utilização da terra nos dois Estados, tanto entre famílias de agricultores $(56,5 \%)$ como famílias pluriativas $(52,9 \%)$. O reflorestamento com variedades exóticas como a acácia-negra indica que, em Padre Eterno Ilges, elas ocupam, em média, $25 \%$ da superfície de área das propriedades de famílias pluriativas, maior que a própria área destinada às lavouras temporárias que chega a 19,7\%. Entre as famílias de agricultores gaúchas o reflorestamento com árvores exóticas representa 16,3\%, a superfície tomada com mata secundária chega a média de $26,3 \%$ e com mata nativa virgem apenas $10,2 \%$. Tais dados indicam, particularmente, uma tendência de redução dos cultivos propriamente comerciais de lavouras que demandam mais mão-de-obra.

Nesse caso, observa-se um efeito direto da pluriatividade sobre os processos produtivos. As famílias pluriativas, em geral mais numerosas e com mais força de trabalho, preferem plantar as variedades silvícolas exóticas, como a acácia-negra, o eucalipto e o pinus, que demandam muita mão-de-obra no momento do plantio, mas poucos tratos culturais. Surge daí a situação que, em outro trabalho (Schneider, 1994, 1999), denominou-se de "cultura de abandono", que se refere ao plantio da acácia-negra nas pequenas propriedades da região da Colônia Velha alemã no Rio Grande do Sul. Em Padre Eterno Ilges, no Rio Grande do Sul, o reflorestamento de áreas com cultivos silvícolas exóticos possui um expressivo significado para as famílias, ocupando, em média, $25 \%$ da superfície das propriedades de pluriativos e 16,3\% nas de agricultores. Em ambos os casos, mais de $90 \%$ das propriedades gaúchas possuem algum tipo de floresta não-nativa destinada à comercialização. No caso gaúcho, a silvicultura da acácia-negra, árvore leguminosa da qual se extrai o tanino para o curtimento do couro e a madeira, mas serve também como fonte de energia calorífica, reveste-se de importância estratégica para as famílias rurais que a cultivam. Como exige poucos tratos culturais e é de fácil manejo e adaptação ao relevo da região, a cultura da acácia constituiu-se em uma forma de obtenção episódica de renda para os proprietários que a cultivam em áreas de baixa fertilidade e, especialmente no caso dos pluriativos, nas áreas cada vez menos ocupadas com variedades de lavoura. Desse modo, a terra continua a produzir um rendimento (que não ocorre antes de seis anos após o plantio, tempo de maturação do cultivo) mesmo sem ocupar a força de trabalho da família, que em geral passa a se dedicar às atividades não-agrícolas fora da propriedade.

No entanto, uma análise mais acurada dos dados expostos também mostra que a diferença entre famílias pluriativas e famílias de agricultores é pouco 
expressiva no que se refere ao uso da terra. A exceção está no item pastagens plantadas, que entre as famílias de agricultores ocupa uma área média de $16,9 \%$ e entre as famílias pluriativas $11,5 \%$. Ambas as situações podem ser facilmente explicadas segundo a variável demográfica e a racionalidade das famílias. Primeiro, dado que as famílias de pluriativos são mais jovens e mais numerosas que as famílias de agricultores (e não há uma apropriação de tecnologias mais favorável entre uma e outra), elas conseguem produzir tanto quanto aquelas dedicadas apenas a atividade agrícola. Logo, explica-se porque ambas não se diferenciam em relação as proporções médias de ocupação de área com lavouras temporárias. Segundo, no único quesito em que realmente se diferencia uma da outra, uso de área com pastagem permanente, a explicação acaba reforçando a tese anterior, pois as pastagens permanentes denotam a utilização da terra com a criação de gado para corte e leite, que é uma atividade que pode ser executada sem a presença de muitas pessoas, o que constitui a realidade das famílias de agricultores.

Em Braço do Sul, na região do Vale do Itajaí, também se destaca a média de área que as famílias de agricultores $(47,6 \%)$ e famílias pluriativas $(47 \%)$ declararam estar ocupadas com mata secundária. Ou seja, na média, quase $50 \%$ da área dos estabelecimentos está ocupada com o chamado "capoeirão", que é a cobertura vegetal que cresce quando a terra deixa de ser utilizada para fins de cultivo. A explicação desta situação reside, em parte, no relevo acidentado da região (típico da Mata Atlântica). Contudo, a principal razão tem sido o rigoroso controle imposto pelas autoridades ambientais, que chegam até mesmo a proibir a formação de lavouras em áreas de encosta de morros. Assim, os órgãos públicos de fiscalização (especialmente a polícia ambiental catarinense) impuseram sérias restrições às práticas agrícolas dos proprietários rurais, o que explica as baixíssimas proporções médias de cultivos de lavoura nas propriedades das famílias pluriativas $(8,2 \%)$ e de agricultores $(9,5 \%)$. Também esta proibição foi apontada pelas famílias pluriativas como uma das principais razões para busca de trabalho fora dos estabelecimentos, em geral nas atividades industriais e comerciais situadas na cidade de Blumenau.

Para conhecer melhor os significados da pluriatividade para o conjunto das unidades familiares, é preciso indagar-se a respeito de suas relações com a atividade agrícola e a dinâmica econômica e produtiva que a propriedade apresenta. Nesse sentido, a combinação de atividades agrícolas e não-agrícolas por uma mesma unidade pode estar relacionada a variáveis como a forma de uso da terra, o ciclo demográfico familiar, entre outras. Cada um desses aspectos pode provocar mudanças internas diferenciadas na propriedade e na forma como os membros da família, especialmente o chefe (mas não somente ele), organizam e gestionam o processo produtivo. Uma das 
preocupações centrais desta pesquisa está relacionada justamente aos efeitos que a pluriatividade pode gerar sobre a propriedade, sobre a família e sobre o processo produtivo.

A relação agricultura e pluriatividade assume características específicas em cada unidade familiar cujos detalhes demandam o estudo aprofundado, em cada caso. No entanto, pode-se conhecer em que medida as famílias pluriativas que possuem ocupações não-agrícolas auxiliam nos trabalhos da propriedade mediante a aferição da freqüência com que se envolvem em tais tarefas. A Tabela 12, a seguir, apresenta as informações das respostas das famílias pluriativas gaúchas e catarinenses sobre a alocação de trabalho em atividades agrícolas. Nos dois casos, verificou-se que, em média, 78,4\% dos membros das famílias pluriativas fornecem algum tipo de ajuda nos trabalhos da propriedade, o que demonstra, conforme já enfatizado, que a busca de um trabalho não-agrícola não implica necessariamente um rompimento com as atividades propriamente agrícolas ou, pelo menos, com determinadas tarefas da propriedade. Essa elevada proporção ocorre tanto em Padre Eterno Ilges, onde chega a $76,9 \%$ o número membros de famílias pluriativas que fornecem ajuda nos trabalhos da propriedade, como em Braço do Sul, onde esta proporção se eleva para $79,2 \%$.

Tabela 12

MEMBROS DAS FAMÍLIAS PLURIATIVAS QUE FORNECEM ALGUM TIPO DEAJUDANOS TRABALHOS DENTRODAPROPRIEDADE NAS COMUNIDADES SELECIONADAS.

\begin{tabular}{|l|c|c|c|}
\hline \multicolumn{1}{|c|}{$\%$} & \multicolumn{2}{|c|}{ Pluriativos } & \\
\cline { 2 - 4 } \multicolumn{1}{c|}{} & RS & SC & Total \\
\hline Sim & 76,9 & 79,2 & 78,4 \\
Não & 15,4 & 20,8 & 18,9 \\
Sem resposta & 7,7 & - & 2,7 \\
\hline Total & 100,0 & 100,0 & 100,0 \\
\hline
\end{tabular}

Fonte: Pesquisa de campo (1998).

Em complementaridade às informações sobre a alocação de trabalho dos membros das famílias pluriativas nas atividades da propriedade (não necessariamente as tarefas agrícolas), buscou-se conhecer a freqüência com que ocorriam essas ajudas e auxílios declarados. Nesse caso, verificou-se um comportamento bastante distinto entre os membros das famílias pluriativas gaúchas e catarinenses. Na Tabela 13, verifica-se que, no primeiro caso, $70 \%$ dos 
membros que auxiliam nas atividades da propriedade declararam fazê-lo de modo "regular" (ou seja, cotidianamente), $20 \%$ disseram que as ajudas ocorriam "às vezes" e 10\% responderam que auxiliavam quando lhes "sobrava algum tempo". Em Braço do Sul, esse comportamento é distinto, pois 47,4\% declararam ajudar apenas "quando sobrava tempo", 42,1\% auxiliavam de modo "regular" e 10,5\% afirmaram que as ajudas ocorriam "às vezes". Como se percebe, o auxílio dos membros das famílias pluriativas nos trabalhos da propriedade não pode ser desprezado, pois ocorre regularmente e, portanto, se reveste de grande importância para a gestão da unidade produtiva.

Tabela 13

FREQÜÊNCIA(\%)COMQUEOSPLURIATIVOSFORNECEMAJUDA NASATIVIDADES DAPROPRIEDADENASCOMUNIDADES SELECIONADAS

\begin{tabular}{|l|c|c|}
\hline \multicolumn{1}{|c|}{$\begin{array}{c}\text { Freqüência da } \\
\text { ajuda \% }\end{array}$} & RS & SC \\
\hline Regularmente & 70,0 & 42,1 \\
Às vezes & 20,0 & 10,5 \\
Quando sobra tempo & 10,0 & 47,4 \\
\hline Total & 100,0 & 100,0 \\
\hline
\end{tabular}

Fonte: Pesquisa de campo (1998).

Conforme já enfatizado, a pluriatividade das unidades familiares pode ser entendida como uma das estratégias das famílias rurais para viabilizar sua reprodução social. A viabilização dessas estratégias dependerá de um conjunto de fatores que se constituem, ao mesmo tempo, de condicionantes internos, como o ciclo demográfico, e influências do exterior, como as pressões do mercado de trabalho ou os efeitos da dinâmica econômica, entre outros aspectos. Cada unidade familiar reage de modo distinto a esse conjunto de fatores e as próprias estratégias adotadas podem variar ao longo do tempo e de acordo com as circunstâncias a serem enfrentadas. Nesse sentido, o recurso às atividades não-agrícolas e à pluriatividade não são imutáveis ou permanentes, pois, nos casos pesquisados, foram encontradas unidades familiares que passaram da condição de famílias pluriativas para famílias de agricultores. Os dados da Tabela 14 indicam que a metade (50\%) das famílias de agricultores gaúchas e 69,2\% no caso de Braço do Sul declararam que algum dos membros de sua família já havia trabalhado em atividades não-agrícolas. 
Tabela 14

FAMÍLIAS DEAGRICULTORES NAS QUAIS ALGUMDOS MEMBROS

JÁ TRABALHOUEMATIVIDADES NÃO-AGRÍCOLAS

NAS COMUNIDADES SELECIONADAS

\begin{tabular}{|l|c|c|}
\hline & RS & SC \\
\hline Sim & 50,0 & 69,2 \\
Não & 50,0 & 23,1 \\
Sem resposta & - & 7,7 \\
\hline Total & 100,0 & 100,0 \\
\hline
\end{tabular}

Fonte: Pesquisa de campo (1998).

Entre as famílias de agricultores que já haviam recorrido à pluriatividade, os membros que deixaram de trabalhar exclusivamente na agricultura em geral eram o chefe da família ou o cônjuge. No Rio Grande do Sul, tanto o chefe como o cônjuge já haviam trabalhado em atividade não-agrícolas (60\% cada), mas, em Santa Catarina, os chefes que abandonaram a condição de pluriativos eram a absoluta maioria $(77,7 \%)$.

Os principais motivos que levaram essas famílias a abandonar a pluriatividade e a combinação da agricultura com outras atividades são variados e não permitem apontar um padrão comum. Os dados da Tabela 15 mostram que as razões dos agricultores gaúchos são distintas daquelas apontadas pelos catarinenses. No caso gaúcho, segundo declararam os "ex-pluriativos", a principal motivação para que abandonassem essa condição foram os problemas de adaptação à cidade (50\%). Em Braço do Sul, os entrevistados apontaram que deixaram as atividades não-agrícolas principalmente devido à aposentadoria $(33,3 \%)$, ou por razões financeiras $(44,4 \%)$, entre as quais a baixa remuneração ou o fato de não encontrarem alternativas melhores. 


\section{Tabela 15}

MOTIVOS QUE LEVARAM OS MEMBROS DAS FAMÍLIAS

DEAGRICULTORESAABANDONAR OEMPREGOEMATIVIDADES

NÃO-AGRÍCOLAS NAS COMUNIDADES SELECIONADAS

\begin{tabular}{|l|c|c|}
\hline \multirow{2}{*}{ Motivações para o abandono da pluriatividade } & \multicolumn{2}{|l|}{ Agricultores (\%) } \\
\cline { 2 - 3 } & RS & SC \\
\hline Problemas de saúde & 25,0 & - \\
Problemas das cidades (violência, desemprego, etc.) & 50,0 & - \\
Falecimento & 25,0 & - \\
Aposentadoria & - & 33,3 \\
Razões financeiras & - & 44,4 \\
Distância entre trabalho e moradia era muito longa & - & 11,1 \\
Sem resposta & - & 11,1 \\
\hline Total & 100,0 & 100,0 \\
\hline
\end{tabular}

Fonte: Pesquisa de campo (1998).

\subsection{MERCADO DETRABALHONÃO-AGRÍCOLA, PLURIATIVIDADEEAGRICULTURAFAMILIAR}

A caracterização do processo produtivo, da propriedade e dos indivíduos que nela habitam permite analisar as relações que as unidades familiares, quer de agricultores ou de pluriativos, estabelecem com o ambiente social e econômico em que estão inseridas. Trata-se, portanto, de elucidar os mecanismos e as estratégias através das quais essas unidades microssociais estabelecem relações com as demais esferas da vida social.

A partir do estudo dessas relações, pretende-se evidenciar os elos através do quais as famílias e/ou indivíduos se integram à divisão social do trabalho e desvendar as nuanças e particularidades dessa inserção. Objetivase, portanto, não apenas identificar e qualificar as relações das unidades familiares com o exterior mas, sobretudo, entender sua racionalidade e sua significação para os agricultores e para os pluriativos. Obviamente, esse exercício interpretativo recolocará em cena várias das questões teóricas e conceituais discutidas, que serão retomadas aqui e cotejadas com os dados obtidos a partir da pesquisa de campo.

Em relação à ocupação da força de trabalho das famílias, pode-se afirmar que há uma significativa parcela de famílias de agricultores que, embora estivessem residindo e vivendo em uma propriedade rural, não estavam ocupadas em atividades agrícolas. Os dados da Tabela 16 indicam que, nas duas comunidades investigadas, apenas pouco mais da metade $(55,6 \%)$ dos agricultores declarou que sua ocupação principal era a atividade agrí- 
cola. Os demais membros das famílias de agricultores nos dois Estados ou eram aposentados $(13,9 \%)$ ou exerciam serviços auxiliares na propriedade $(19,4 \%$ dos membros no caso gaúcho e $8,3 \%$ no catarinense) como cuidar de pequenos animais, fazer limpeza, etc. Na localidade de Braço do Sul, no Estado de Santa Catarina, 13,9\% dos membros das famílias de agricultores ocupavamse em serviços domésticos como cozinhar, limpar e cuidar de crianças e idosos.

\section{Tabela 16 \\ OCUPAÇÃO PRINCIPALDOS MEMBROS DASFAMÍLIAS DEAGRICULTORESEPLURIATIVOS NASCOMUNIDADES SELECIONADAS}

\begin{tabular}{|l|cc|cc|}
\hline \multirow{2}{*}{\multicolumn{1}{|c|}{ Atividades }} & \multicolumn{3}{|c|}{ Agricultores (\%) } & \multicolumn{2}{c|}{ Pluriativos (\%) } \\
\cline { 2 - 5 } & $\mathrm{RS}$ & $\mathrm{SC}$ & $\mathrm{RS}$ & $\mathrm{SC}$ \\
\hline Agrícolas & 55,6 & 55,6 & 23,2 & 30,4 \\
Não-agrícolas & - & - & 36,2 & 33,9 \\
Serviços domésticos & - & 13,9 & 15,9 & 13,9 \\
Ajuda em ativ. não-agrícola que geram rendas & - & 2,8 & - & - \\
Aposentado & 13,9 & 13,9 & 5,8 & 4,3 \\
Não trabalha* & 8,3 & 5,6 & 1,4 & 5,2 \\
Desempregado & - & - & - & 0,9 \\
Serviços de auxílio na propriedade** & 19,4 & 8,3 & 15,9 & 11,3 \\
Outros & 2,8 & - & 1,4 & - \\
\hline Total & 100,0 & 100,0 & 100,0 & 100,0 \\
\hline
\end{tabular}

* Considera-se com "não trabalha" as crianças menores de 5 anos de idade, os inválidos, os deficientes e os idosos impossibilitados de exercer qualquer tipo de atividade física.

** Define-se como serviços de auxílio na propriedade as atividades que desfrutam do status de ajuda ou apoio, como o cuidado de pequenos animais, limpeza, etc., realizadas por crianças entre os 5 e 14 anos de idade.

Fonte: Pesquisa de campo (1998).

No que diz respeito às famílias de pluriativos, elas se caracterizam por ocupar a maior parte de seus membros em atividades não-agrícolas. Essas formas de ocupação alcançam 36,2\%, nas famílias gaúchas, e chegam a 33,9\%, entre as famílias pluriativas catarinenses. Nesse caso, contudo, o mais importante a salientar é a combinação significativa que há entre atividades agrícolas e não-agrícolas, entre os diferentes membros das famílias. Em Padre Eterno Ilges, na microrregião da Encosta da Serra gaúcha, a presença de indivíduos que se ocupam do trabalho agrícola entre as famílias pluriativas chegou a ser de $23,2 \%$, e no caso catarinense foi um pouco superior, atingindo $30,4 \%$. Esses dados demonstram que não é o fato da família ser pluriativa ou ter um ou 
outro membro empregado em atividades não-agrícolas que retira a importância da agricultura para essas famílias ${ }^{73}$ Nesse caso, a atividade fora da propriedade pode ser apenas um trabalho acessório ou temporário para fazer frente às dificuldades conjunturais da atividade principal. Por essa razão, as atividades domésticas (provavelmente dos membros mais jovens e/ou idosos) ocupam a terceira posição de importância entre as famílias de pluriativos $(15,9 \%$ no caso gaúcho e 13,9\% no catarinense).

Entre as famílias pluriativas não se verifica distinção significativa entre homens e mulheres com relação à ocupação principal da força de trabalho em atividades agrícolas, registrando-se uma variação entre $20 \%$ a $31,6 \%$, conforme indicado na Tabela 17, a seguir. Contudo, no que se refere às atividades não-agrícolas, percebe-se uma nítida tendência dos homens de ocupação dos postos de trabalho nessas tarefas. Em Padre Eterno Ilges, em 47,1\% das situações os homens declararam que sua ocupação principal era uma atividade não-agrícola, ao passo que apenas $25,7 \%$ das mulheres afirmaram trabalhar nestas atividades. Já em Braço do Sul, a proporção de homens que se ocupavam em atividades não-agrícolas chegou a $44,8 \%$, para apenas $22,8 \%$ de mulheres. Portanto, tanto no Rio Grande do Sul como em Santa Catarina, a pluriatividade, como atividade principal, revela-se uma ocupação preponderantemente masculina. Outro aspecto que a divisão sexual do trabalho evidencia nessas famílias é que são raros os membros masculinos que declaram ter como ocupação principal os serviços domésticos, indicando que este ainda continua a ser um campo de amplo domínio das mulheres.

\footnotetext{
${ }^{73}$ Não se pode esquecer que os dados referem-se à atividade principal com a qual se ocupam todos os membros da família, sejam crianças, jovens, adultos ou idosos. Desse modo, os percentuais da tabela anterior referem-se a valores absolutos diferentes (que é o " $n$ " total de indivíduos das famílias), que resultam da soma de todos os indivíduos (divididos entre agricultores ou pluriativos) ocupados e não-ocupados.
} 
Tabela 17

ATIVIDADE PRINCIPALDOS MEMBROS DAS FAMÍLIAS PLURIATIVAS, SEGUNDO SEXO, NAS COMUNIDADE SELECIONADAS

\begin{tabular}{|l|cc|cc|cc|}
\hline \multirow{4}{*}{\multicolumn{1}{c|}{ Atividades }} & \multicolumn{4}{c|}{ Pluriativos (\%) } & \multicolumn{2}{c|}{ Total } \\
\cline { 2 - 5 } & Masculino & Feminino & & \\
\cline { 2 - 5 } & RS & SC & RS & SC & RS & SC \\
\hline Agrícolas & 26,5 & 29,3 & 20,0 & 31,6 & 23,2 & 30,4 \\
Não-agrícolas & 47,1 & 44,8 & 25,7 & 22,8 & 36,2 & 33,9 \\
Serviços domésticos & 2,9 & - & 28,6 & 28,1 & 15,9 & 13,9 \\
Aposentados & 2,9 & 5,2 & 8,6 & 3,5 & 5,8 & 4,3 \\
Não trabalha* & 2,9 & 5,2 & - & 5,3 & 1,4 & 5,2 \\
Outros & 2,9 & - & - & - & 1,4 & - \\
Desempregados & - & 1,7 & - & - & - & 0,9 \\
Serviços de auxílio na propriedade** & 14,7 & 13,8 & 17,1 & 8,8 & 15,9 & 11,3 \\
\hline
\end{tabular}

(*) e (**), conforme notas da Tabela 16.

Fonte: Pesquisa de campo (1998).

Tabela 18

ATIVIDADE PRINCIPALDOS MEMBROS DASFAMÍLIAS

DEAGRICULTORES,SEGUNDOSEXO,NASCOMUNIDADESELECIONADAS

\begin{tabular}{|l|cc|cc|cc|}
\hline \multirow{2}{*}{ Atividades } & \multicolumn{4}{|c|}{ Agricultores (\%) } & \multirow{2}{*}{ Total } \\
\cline { 2 - 7 } & Masculino & Feminino & & \\
\cline { 2 - 7 } & RS & SC & RS & SC & RS & SC \\
\hline Agrícolas & 64,7 & 80,0 & 47,4 & 38,1 & 55,6 & 55,6 \\
Serviços domésticos & - & - & - & 23,8 & - & 13,9 \\
Não-agrícolas dentro da propriedade & - & - & - & 4,8 & - & 2,8 \\
Aposentado & 5,9 & 13,3 & 21,1 & 14,3 & 13,9 & 13,9 \\
Não trabalha* & 5,9 & 6,7 & 10,5 & 4,8 & 8,3 & 5,6 \\
Outros & - & - & 5,3 & & 2,8 & - \\
Serviços de auxílio na propriedade** & 23,5 & - & 15,8 & 14,3 & 19,4 & 8,3 \\
\hline Total & 100,0 & 100,0 & 100,0 & 100,0 & 100,0 & 100,0 \\
\hline
\end{tabular}

(*) e (**), conforme notas da Tabela 16.

Fonte: Pesquisa de campo (1998). 
Em relação aos membros das famílias de agricultores, as ocupações principais segundo sua separação por sexo indicam que há um significativo predomínio dos homens no exercício das atividades agrícolas. Na região gaúcha da Encosta da Serra, $64,7 \%$ dos homens e 47,4\% de mulheres declaram que a agricultura era sua principal ocupação, enquanto na região catarinense do Vale do Itajaí essa proporção subiu para $80 \%$ entre os homens e 38,1\% das mulheres, conforme mostra a Tabela 18. Em Padre Eterno Ilges, 21,1\% das mulheres agricultoras estavam aposentadas e, em Braço do Sul, 23,8\% delas tinha como ocupação principal as atividades domésticas.

Outra dimensão das famílias, apresentada na Tabela 19, que pode ser analisada a partir da ocupação principal é quanto à sua posição na hierarquia familiar. Entre as famílias de agricultores, 69,6\% do chefes, 57,1\% dos cônjuges e $43,3 \%$ dos filhos acima de 14 anos de idade tinham como ocupação principal as atividades agrícolas, corroborando a afirmativa anterior de que nem mesmo os próprios agricultores têm como trabalho principal uma atividade agrícola. Na verdade, isso se deve ao fato de que mais de $20 \%$ de chefes e de cônjuges ( $26,1 \%$ e $21,4 \%$, respectivamente), entre os agricultores, declararam que sua ocupação principal é ser aposentado, embora isto não signifique que não trabalhem mais.

\section{Tabela 19}

OCUPAÇÃO PRINCIPAL DOS MEMBROS DAS FAMÍLIAS DEAGRICULTORES SEGUNDO SUAPOSIÇÃONAFAMÍLIA NAS COMUNIDADE SELECIONADAS

\begin{tabular}{|l|c|c|c|c|c|}
\hline \multirow{2}{*}{ Atividades } & \multicolumn{5}{|c|}{ Posição na família (\%) } \\
\cline { 2 - 7 } & Chefe & Cônjuge & Filhos & Avós & Outros \\
\hline Agrícolas & 69,6 & 57,1 & 43,3 & - & 75,0 \\
Serviços domésticos & 4,3 & 14,3 & 6,7 & - & - \\
Ativ. não-agrícolas dentro propriedade & - & 7,1 & - & - & - \\
Aposentado & 26,1 & 21,4 & - & 100,0 & - \\
Não trabalha* & - & - & 16,7 & - & - \\
Outros & - & - & 3,3 & - & - \\
Serviços de auxílio na propriedade** & - & - & 30,0 & - & 25,0 \\
\hline Total & 100,0 & 100,0 & 100,0 & 100,0 & 100,0 \\
\hline
\end{tabular}

(*) e (**), conforme notas da Tabela 16.

Fonte: Pesquisa de campo (1998).

Entre as famílias de pluriativos, nos dois Estados, os chefes e os cônjuges (pouco mais de $51 \%$ em ambos os casos) também declararam que sua principal ocupação é uma atividade agrícola, embora também sejam 
expressivas as proporções daqueles que afirmaram que sua principal ocupação era uma atividade não-agrícola ( $45,9 \%$ e $24,2 \%$, respectivamente). Por outro lado, tal como indica a Tabela 20 , chega a quase $40 \%$ o percentual de filhos, com idade superior a 14 anos, que têm como ocupação principal uma atividade não-agrícola. Pelo tipo de força de trabalho que as indústrias têxteis, no Vale do Itajaí em Santa Catarina, e calçadistas, na Colônia Velha alemã no Rio Grande do Sul, demandam, é possível que haja uma preferência pela contratação de indivíduos mais jovens.

\section{Tabela 20}

OCUPAÇÃO PRINCIPAL DOS MEMBROS DAS FAMÍLIAS

DE PLURIATIVOS SEGUNDO SUAPOSIÇÃO NAFAMÍLIA NAS COMUNIDADE SELECIONADAS

\begin{tabular}{|l|c|c|c|c|c|}
\hline \multirow{2}{*}{ Atividades } & \multicolumn{4}{|c|}{ Posição na família (\%) } \\
\cline { 2 - 7 } & Chefe & Cônjuge & Filhos & Avós & Outros \\
\hline Agrícolas & 51,4 & 51,5 & 15,6 & - & - \\
Não-agrícolas & 45,9 & 24,2 & 38,5 & - & 22,2 \\
Serviços domésticos & - & 24,2 & 17,7 & 11,1 & 11,1 \\
Aposentado & 2,7 & - & - & 88,9 & - \\
Não Trabalha* & - & - & 3,1 & - & 44,4 \\
Outros & - & - & 1,0 & - & - \\
Desempregado & - & - & 1,0 & - & - \\
Serviços de auxílio na propriedade** & - & - & 22,9 & - & 22,2 \\
\hline Total & 100,0 & 100,0 & 100,0 & 100,0 & 100,0 \\
\hline
\end{tabular}

(*) e (**), conforme notas da Tabela 16.

Fonte: Pesquisa de campo (1998).

No que se refere aos principais ramos de atividades que empregam a mão-de-obra das famílias pluriativas, em Padre Eterno Ilges e em Braço do Sul, não resta dúvida de que a indústria, especialmente os setores têxtil e calçadista, é o ramo que mais recruta esse tipo de força de trabalho. No caso gaúcho, como indica a Tabela 21 , o ramo industrial absorve $84 \%$ dos pluriativos que trabalham em atividades não-agrícolas e, no caso catarinense, essa proporção diminui para 59\%. Nesse último caso, vale a pena registrar que a alocação da mão-de-obra dos pluriativos é um pouco mais diversificada frente ao caso gaúcho e se estende para outros ramos como a construção civil e a transformação artesanal. 
Tabela 21

PRINCIPAIS RAMOS DEATIVIDADE NÃO-AGRÍCOLAS DAS FAMÍLIAS PLURIATIVAS NAS COMUNIDADE SELECIONADAS

\begin{tabular}{|l|c|c|}
\hline \multirow{2}{*}{\multicolumn{1}{|c|}{ Ramos }} & \multicolumn{2}{|c|}{ Pluriativos (\%) } \\
\cline { 2 - 3 } & RS & SC \\
\hline Indústria & 84,0 & 59,0 \\
Comércio & 4,0 & 5,1 \\
Construção civil & - & 12,8 \\
Transformação artesanal & - & 7,7 \\
Transporte & - & 2,6 \\
Serviço público & 8,0 & 5,1 \\
Serviços pessoais & - & 2,6 \\
Sem resposta & 4,0 & 5,1 \\
\hline
\end{tabular}

Fonte: Pesquisa de campo (1998).

Em Padre Eterno Ilges, a preponderância do ramo industrial como principal empregador da força de trabalho fica ainda mais evidente quando separam-se os membros das famílias pluriativas segundo o sexo, conforme dados apresentados na Tabela 22, a seguir. Nesse caso, $75 \%$ dos membros pluriativos do sexo masculino e todas as mulheres encontram-se empregados na indústria. Já em Braço do Sul, a estratificação segundo o sexo dos membros pluriativos acaba permitindo, ao mesmo tempo, visualizar melhor a diversidade de ramos que absorvem a força de trabalho pluriativa masculina e acusar o aumento dos pluriativos do sexo feminino que estão ocupados no ramo industrial $(69,2 \%)$.

Tabela 22

PRINCIPAIS RAMOS DE ATIVIDADE NÃO-AGRÍCOLAS DAS FAMÍLIAS PLURIATIVAS, SEGUNDO O SEXO, NAS COMUNIDADES SELECIONADAS

\begin{tabular}{|l|cc|cc|}
\hline \multirow{2}{*}{ Ramos } & \multicolumn{3}{|c|}{ Masculino (\%) } & \multicolumn{2}{c|}{ Feminino (\%) } \\
\cline { 2 - 5 } & RS & SC & RS & SC \\
\hline Indústria & 75,0 & 53,8 & 100,0 & 69,2 \\
Comércio & 6,2 & 3,8 & - & 7,7 \\
Construção civil & - & 19,2 & - & - \\
Transformação artesanal & - & 11,5 & - & - \\
Transporte & - & 3,8 & - & - \\
Serviço público & 12,5 & 3,8 & - & 7,7 \\
Serviços pessoais & - & - & - & 7,7 \\
Sem resposta & 6,2 & - & - & - \\
\hline Total & - & 3,8 & - & 7,7 \\
\hline
\end{tabular}

Fonte: Pesquisa de campo (1998). 
As famílias pluriativas gaúchas e catarinenses mais jovens trabalham exclusivamente no ramo industrial, conforme indicado na Tabela 23 , a seguir. Entretanto, à medida que aumentam as faixas de idade, a participação no emprego industrial vai regredindo, passando para $74,1 \%$ entre os que possuem idades entre 19 e 34 anos, e para $61,1 \%$ entre os que se situam na faixa entre 35 a 59 anos. Essa informação nos permite concluir que as chances de obtenção de um emprego no ramo industrial têxtil ou calçadista são diretamente proporcionais à idade dos candidatos, sendo preferidos os mais jovens.

Tabela 23

PRINCIPAIS RAMOS DE ATIVIDADE NÃO-AGRÍCOLAS DAS FAMÍLIAS PLURIATIVAS, SEGUNDO FAIXAS DE IDADE, NAS COMUNIDADES SELECIONADAS

\begin{tabular}{|l|c|c|c|c|c|}
\hline \multirow{2}{*}{\multicolumn{1}{|c|}{ Ramos }} & \multicolumn{4}{|c|}{ Faixas de idade (\%) } \\
\cline { 2 - 5 } & 11 a 18 & 19 a 34 & 35 a 59 & 60 ou mais \\
\hline Indústria & 100,0 & 74,1 & 61,1 & - \\
Comércio & - & 3,7 & 11,1 & - \\
Construção civil & - & 11,1 & 5,6 & - \\
Transformação artesanal & - & 3,7 & - & 100,0 \\
Transporte & - & - & 5,6 & - \\
Serviço público & - & 7,4 & 11,1 & - \\
Serviços pessoais & - & - & 5,6 & - \\
\hline Total & 100,0 & 100,0 & 100,0 & 100,0 \\
\hline
\end{tabular}

Fonte: Pesquisa de campo (1998).

Entre os membros das famílias pluriativas gaúchas há dúvidas sobre as vantagens financeiras de empregar-se em atividades não-agrícolas. A Tabela 24 mostra que apenas 46,2\% dos membros pluriativos gaúchos consideraram que o trabalho não-agrícola representa a melhor forma de ganhar dinheiro. Para uma proporção expressiva de $23,1 \%$, trata-se tão-somente de uma alternativa ao trabalho penoso e pouco rentável da agricultura. Mas há também 15,4\% de pluriativos gaúchos que são indiferentes ao seu significado, pois consideraram que o trabalho em atividades não-agrícolas é apenas um tipo de emprego ou trabalho como outro qualquer. Já os membros das famílias pluriativas catarinenses mostraram-se mais convencidos em relação ao significado monetário dos trabalhos não-agrícolas, pois quase $80 \%$ destacaram que é a melhor forma de ganhar dinheiro, seguidos por uma minoria de $12,5 \%$ que a consideraram uma alternativa ao trabalho agrícola. 


\section{Tabela 24}

SIGNIFICADOS ATRIBUÍDOS AOTRABALHOEMATIVIDADES

NÃO-AGRÍCOLAS, SEGUNDOAS FAMÍLIAS PLURIATIVAS, NAS COMUNIDADES SELECIONADAS

\begin{tabular}{|l|c:c|}
\hline \multicolumn{1}{|c|}{ Opiniões dos pluriativos (\%) } & RS & SC \\
\hline Melhor forma de ganhar dinheiro & 46,2 & 79,2 \\
Alternativa ao trabalho na agricultura & 23,1 & 12,5 \\
Atividade complementar à agricultura & - & 4,2 \\
Alternativa temporária frente às dificuldades na agricultura & & 4,2 \\
Possibilidade de arranjar trabalho para os jovens & 7,7 & - \\
Opção de emprego como outra qualquer & 15,4 & - \\
Possibilidade dos filhos continuarem os estudos & 7,7 & - \\
\hline Total & 100,0 & 100,0 \\
\hline
\end{tabular}

Fonte: Pesquisa de campo (1998).

\subsection{O PAPELDAPLURIATIVIDADENAREPRODUÇÃO SOCIAL DAS FAMÍLIAS RURAIS: UMACOMPARAÇÃO ENTREAS RENDAS AGRÍCOLAS ENÃO-AGRÍCOLAS}

O debate sobre as rendas é um tema controvertido sobre o qual é difícil estabelecer um consenso no terreno metodológico. Entre os principais problemas pode-se citar, por exemplo, a extrema dificuldade dos pesquisadores em obter dados fidedignos e confiáveis dos seus entrevistados, devido à resistência ou omissão em fornecer informações sobre assuntos de ordem privada. Não obstante essas dificuldades, os estudos sociológicos mais recentes incorporam de forma crescente a variável renda como um indicador que permite identificar os mecanismos de reprodução social de determinados grupos sociais.

Esse também é o objetivo da análise que se pretende empreender nesta seção. Contudo, não se trata de discutir as rendas agrícolas e não-agrícolas ou seu valor mercantil exclusivamente do ponto de vista da satisfação das necessidades. Ao contrário, busca-se identificar a sua origem (agrícola, não-agrícola ou outra), verificar quem são os indivíduos das unidades familiares que as produzem, analisar a forma como são repartidos e avaliar seu destino no interior das unidades familiares.

No que se refere à origem dos rendimentos, o ramo industrial aparece como a principal fonte dos ganhos em atividades não-agrícolas das famílias pluriativas estudadas na comunidade de Padre Eterno Ilges (pertencente ao município de Santa Maria do Herval), no Rio Grande do Sul, e Braço do Sul, distrito de Vila Itoupava (pertencente ao município de Blumenau), em Santa Catarina.Em ambos os locais, conforme mostra a Tabela 25, a seguir, as famílias pluriativas que ti- 
nham membros ocupados na indústria chegavam a 76,9\% na localidade de Padre Eterno Ilges e a 50\%, em Braço do Sul. No caso gaúcho, a segunda posição é dividida entre três outros ramos, e no caso catarinense, a construção civil é responsável por $20,8 \%$ das ocupações dos pluriativos, seguida pela transformação artesanal $(12,5 \%)$.

Tabela 25

RAMOS DEATIVIDADES NÃO-AGRÍCOLAS QUEGERARAM MAIORES RENDIMENTOS PARAAS FAMÍLIAS PLURIATIVAS, NASCOMUNIDADES SELECIONADAS

\begin{tabular}{|l|c|c|c|c|}
\hline \multirow{2}{*}{ Ramos de atividades } & \multicolumn{2}{|c|}{ RS } & \multicolumn{2}{c|}{ SC } \\
\cline { 2 - 5 } & $\mathrm{n}$ & $\%$ & $\mathrm{n}$ & $\%$ \\
\hline Indústria & 10 & 76,9 & 12 & 50,0 \\
Construção civil & - & - & 5 & 20,8 \\
Transformação artesanal & - & - & 3 & 12,5 \\
Serviços pessoais & - & - & 1 & 4,2 \\
Serviço público & 1 & 7,7 & 1 & 4,2 \\
Comércio & 1 & 7,7 & 1 & 4,2 \\
Transporte & 1 & 7,7 & 1 & 4,2 \\
\hline Total & 13 & 100,00 & 24 & 100,00 \\
\hline
\end{tabular}

Fonte: Pesquisa de campo (1998).

Antes de passar à análise dos dados gerados a partir das informações coletadas pela pesquisa de campo, convém um esclarecimento sobre a maneira segundo a qual eles foram gerados e construídos. Nas entrevistas com as famílias de agricultores e de pluriativos, o entrevistado foi convidado a indicar a origem da renda mensal de sua família, fazendo o cálculo em salários mínimos. Quando havia mais de um indivíduo ocupado em uma mesma atividade, procedia-se à soma, em salários mínimos, dos valores que esses auferiam por mês, e marcava-se a faixa salarial correspondente. No entanto, no momento da compilação dos dados, verificou-se que os valores que os entrevistados informavam como rendas obtidas com as atividades agrícolas tinham uma natureza diversa daquelas rendas que eram auferidas em atividades não-agrícolas. No primeiro caso, o entrevistado informava o montante das receitas líquidas obtidas como resultado do trabalho agrícola. Mas este cálculo não considerava os gastos com a remuneração da força de trabalho, a depreciação da maquinaria ou os gastos com equipamentos e instalações, e, igualmente, não considerava também como renda os valores que deixavam de ser gastos com a alimentação da família, produzidos na própria propriedade. Portanto, o que o entrevistado informava como "renda", na verdade constituía-se em 
seu excedente econômico, ou seja, aquilo que (em valores aproximados) ele embolsava na forma de dinheiro ao final de um mês. Situação inversa ocorria com os rendimentos gerados pelas atividades não-agrícolas, em geral advindos de fora da propriedade, quando o indivíduo recebia o equivalente ao valor da venda de sua força de trabalho. Para os pluriativos, esses valores correspondiam à sua renda mensal, ou seja, era a soma total da quantidade de dinheiro que mensalmente recebiam pelo seu trabalho, ainda que não descontados os valores das despesas correntes e dos custos de sua manutenção.

Comparando essas duas situações, percebe-se que há aspectos que as assemelham e outros que as diferenciam radicalmente. O que há de comum é que, em ambos os casos, as somas monetárias obtidas são oriundas do cálculo dos valores, na forma de dinheiro, que a família recebe ao final de cada mês de trabalho. Por outro lado, ao se compararem os ganhos gerados pelas atividades agrícolas e não-agrícolas, percebe-se que as primeiras acabam sendo subestimadas em função do tipo de cálculo realizado pelo agricultor. Para o agricultor, sua "renda" representa a receita líquida que é decorrente do cálculo daquilo que "sobra", depois de realizados todos os descontos e pagamentos (ainda que não incluídos neste cálculo os quesitos anteriormente mencionados). Para os pluriativos, os ganhos com as atividades não-agrícolas, obtidos pela remuneração de atividades em geral executadas fora da propriedade, aparecem em montantes quase sempre maiores, sem considerar que desse valor deverão ainda ser subtraídos, posteriormente, os gastos com alimentação, moradia, vestimentas, etc. Assim, estabelecem-se diferenças fundamentais entre essas duas formas de obtenção dos rendimentos em dinheiro, operando-se em um caso com a renda líquida e noutro com a "renda bruta". Por esta razão, o que se compara, efetivamente, são as entradas monetárias realizadas por famílias de agricultores e famílias pluriativas. Essas entradas monetárias expressam os valores auferidos em dinheiro pelos membros dessas famílias sem levar em conta nenhum tipo de despesa ou depreciação a elas vinculado. Isto significa, na prática, que a análise aqui realizada busca apresentar e comparar os ganhos monetários em dinheiro das famílias de agricultores e famílias pluriativas.

A Tabela 26, a seguir, revela os valores médios ${ }^{74}$ das entradas monetárias das famílias de agricultores e famílias pluriativas. A primeira observação é que a média das entradas monetárias das famílias pluriativas é o dobro em relação às famílias de agricultores. As famílias pluriativas em Santa Maria do Herval obtêm, em média, entradas monetárias mensais que giram em torno de 6,8 salários mínimos e, em Blumenau, as entradas médias chegam a 6,1 salários mínimos. Já

\footnotetext{
${ }^{74}$ Esta média resulta da soma de todos os salários mínimos declarados e divididos pelo número de respondentes.
} 
as famílias de agricultores possuem uma média geral de entradas monetárias mensais que chega apenas à metade daquelas obtidas pelas famílias pluriativas. As famílias de agricultores gaúchos conseguem somar, em média, ganhos em dinheiro que giram por volta dos 3,1 salários mínimos por mês e as famílias de agricultores catarinenses obtêm, em média, entradas de 3,2 salários mínimos mensais.

\section{Tabela 26 \\ ENTRADAS MONETÁRIAS DAS FAMÍLIAS DE PLURIATIVOS \\ EDASFAMÍLIAS DEAGRICULTORES NAS COMUNIDADES SELECIONADAS (EM SALÁRIOS MÍNIMOS)}

\begin{tabular}{|c|c|c|c|c|c|c|}
\hline \multirow{2}{*}{ Origem das entradas monetárias } & \multicolumn{3}{|c|}{ Pluriativos } & \multicolumn{3}{|c|}{ Agricultores } \\
\hline & RS & $\mathrm{SC}$ & Total & RS & $\mathrm{SC}$ & Total \\
\hline Atividade a & 1,1 & 1,8 & 1,5 & 2,1 & 1,3 & 1,7 \\
\hline Ativ & 4,3 & 4,1 & 4,2 & - & - & - \\
\hline Atividade não-agrícola dentro da propriedade ${ }^{2}$ & 2,0 & 0,8 & 1,4 & 1,0 & 0,6 & 0,7 \\
\hline Aposentadorias & 1,6 & 1,8 & 1,7 & 2,0 & 3,0 & 2,7 \\
\hline Outras entradas & 2,0 & - & 2,0 & - & 2,0 & 2,0 \\
\hline Entradas eventu & 0,9 & 1,3 & 1,1 & - & 1,0 & 1,0 \\
\hline Média de todas as entradas monetárias por $\mathrm{f}$ & 6,8 & 6,1 & 6,3 & 3.1 & 3,2 & 3,2 \\
\hline
\end{tabular}

${ }^{1}$ Um salário mínimo equivalia a R \$ 130,00, em setembro de 1998, quando foi realizada a pesquisa de campo.

${ }^{2}$ São rendas advindas de atividades não-agrícolas como o artesanato, o beneficiamento ou processamento da produção agropecuária (embutidos de carnes, doces, etc), realizadas dentro da própria propriedade.

Fonte: Pesquisa de campo (1998).

Entre as famílias pluriativas, a principal fonte de renda são as atividades não-agrícolas, que em média aportam 4,2 salários mínimos mensais para essas famílias. Entretanto, também merecem destaque as entradas monetárias que as famílias pluriativas obtêm com as aposentadorias, que em média atingem 1,7 salários mínimos por mês. Na localidade de Padre Eterno Ilges, no Rio Grande do Sul, as entradas das famílias pluriativas com aluguéis de casas nas cidades também é importante e chega a representar uma renda média mensal de 2 salários mínimos.

Em relação às fontes de rendimentos das famílias de agricultores, a principal conclusão que pode ser extraída dos dados da pesquisa de campo é a de que mais de dois terços (84\%) das suas entradas monetárias provêm das aposentadorias que recebem. Ou seja, dos 3,2 salários mínimos, em média, que obtêm como rendimentos monetários e embolsam na forma de dinheiro, 2,7 
salários mínimos são oriundos das transferências sociais públicas via pagamento de aposentadorias ou pensões. Nesse caso, não seria exagero afirmar que é o Estado que mantém essas famílias de agricultores, pois suas entradas monetárias dependem significativamente dos ganhos obtidos com aposentadorias. No caso gaúcho, o dinheiro ganho com as atividades agrícolas dos agricultores chega praticamente a igualar-se (em média, 2 salários mínimos) com as entradas obtidas com as aposentadorias. Em Braço do Sul, as transferências sociais (em média, 3 salários mínimos) representam mais do que o dobro dos ganhos monetários obtidos na agricultura (1,3 salários mínimos).

Como se percebe, as entradas monetárias das famílias de agricultores expressam, de modo bastante fidedigno, a forma de utilização da propriedade e as características do grupo familiar e do processo produtivo. Conforme destacado anteriormente, as famílias de agricultores são formadas, em sua maioria, apenas pelos cônjuges, com idades médias bastante superiores às famílias pluriativas que, além disso, cultivam pequenas faixas de terra com lavouras de produtos destinados majoritariamente ao autoconsumo. Portanto, em função dessas características, vendem muito pouco de sua produção agrícola e, em consequiência, são baixas as rendas agrícolas, o que as obriga, conforme mostra a tabela anterior, a sobreviverem basicamente das transferências sociais.

Já as famílias pluriativas são mais numerosas e mais jovens, com vários de seus membros em idade ativa para o trabalho. Sua produção agrícola também é destinada basicamente ao autoconsumo da unidade familiar e, em geral, é o chefe que permanece na propriedade enquanto os demais membros trabalham em atividades não-agrícolas. No entanto, ao contrário das famílias que vivem exclusivamente das rendas agrícolas, essas famílias têm como fonte principal de rendas monetárias as atividades nãoagrícolas, o que lhes confere uma característica absolutamente distinta.

Apesar das limitações em relação à aferição dos rendimentos antes destacadas, no questionário que orientou o levantamento de dados nos dois casos estudados foi incluída uma pergunta sobre o saldo financeiro mensal que o entrevistado considerava alcançar, após deduzidos todos os gastos e despesas de sua família. Nessa questão, a família de agricultores ou a família pluriativa, conforme o caso, era estimulada a fornecer o saldo financeiro em salários mínimos que considerava ser "o lucro" de seu trabalho. Entendido dessa forma, esse saldo, na verdade, representa o excedente econômico produzido pelas famílias de agricultores e famílias pluriativas. 
Tabela 27

EXCEDENTE ECONÔMICO MÉDIO DAS FAMÍLIAS DE PLURIATIVOS EFAMÍLIAS DE AGRICULTORES NAS COMUNIDADES SELECIONADAS

\begin{tabular}{|l|ccc|ccc|}
\hline \multirow{2}{*}{$\begin{array}{c}\text { Faixas de } \\
\text { salários mínimos }\end{array}$} & \multicolumn{3}{|c|}{ Pluriativos (\%) } & \multicolumn{3}{c|}{ Agricultores (\%) } \\
\cline { 2 - 7 } & RS & SC & Total & RS & SC & Total \\
\hline Não sobra nada & 7,7 & 29,2 & 21,6 & - & 38,5 & 21,7 \\
até 0,5 & 15,4 & 8,3 & 10,8 & 40,0 & - & 17,4 \\
de 0,5 a 1 & 61,5 & 20,8 & 35,1 & 10,0 & 30,8 & 21,7 \\
de 1 a 2 & 7,7 & 16,7 & 13,5 & 30,0 & 7,7 & 17,4 \\
de 2 a 3 & 7,7 & 4,2 & 5,4 & 10,0 & 7,7 & 8,7 \\
de 3 a 4 & - & 8,3 & 5,4 & - & - & - \\
de 7 a 8 & - & 4,2 & 2,7 & - & - & - \\
Sem resposta & - & 8,3 & 5,4 & 10,0 & 15,4 & 13 \\
\hline Total & 100,0 & 100,0 & 100,0 & 100,0 & 100,0 & 100 \\
\hline
\end{tabular}

${ }^{1}$ Um salário mínimo equivalia a R \$ 130,00, em setembro de 1998, quando foi realizada a pesquisa de campo.

Fonte: Pesquisa de campo (1998).

Ao se realizarem as entrevistas, evidenciou-se que o assunto gerava desconforto e até mesmo desconfiança entre os inquiridos. Em consequiência, os valores revelados pelos entrevistados devem ser tomados com certa cautela. No entanto, acredita-se que esses dados sejam satisfatórios pois, em última análise, a probabilidade de que não sejam absolutamente objetivos é a mesma dos dados levantados nas pesquisas dos censos realizados pelo IBGE ou das declarações anuais de renda para a Receita Federal, uma vez que foi mantido semelhante rigor e isenção no momento da coleta das informações. A dúvida acerca das respostas do entrevistado sobre seu saldo monetário ao final de um mês não compromete, acredita-se, a confiabilidade das informações prestadas e não autoriza, portanto, que os dados obtidos sejam colocados sob suspeição.

Feitas todas as ressalvas quanto ao sigilo das informações, ainda assim muitos entrevistados optaram por declarar que não obtêm nenhum tipo de excedente ou lucro, o que na verdade também pode ser interpretado como uma forma de furtar-se a responder ao questionamento. Entre aqueles que responderam, especialmente as famílias gaúchas, percebeu-se que os excedentes das famílias pluriativas são relativamente superiores aos das famílias de agricultores. As famílias de pluriativos que possuem um excedente mensal de até um salário mínimo são 76,9\% em Santa Maria do Herval e 29,1\%, em Blumenau. Neste último caso, no entanto, as famílias pluriativas que têm excedentes 
mensais acima de um salário mínimo somam 33,4\%, o que se deve em grande parte aos melhores salários pagos pelas indústrias têxteis da região. Em Padre Eterno Ilges, 50\% dos excedentes dos agricultores situam-se na faixa com até um salário mínimo mensal e, em Braço do Sul, chegam a 30,8\%. No caso gaúcho, há uma parcela expressiva de $40 \%$ de famílias de agricultores que declararam possuir excedentes acima de um salário.

Além das entrevistas em relação às suas rendas, existem outros mecanismos para obter informações e indicadores sobre os rendimentos. Um desses mecanismos refere-se à apuração de informações sobre a posse de bens e o investimento do excedente monetário. Em relação a este último, as famílias foram questionadas acerca da posse de caderneta de poupança e a regularidade de depósitos, o que indica a existência ou não de algum excedente para utilização futura, bem como a aplicação de dinheiro em outros investimentos.

A Tabela 28, a seguir, apresenta as informações sobre a forma de utilização dos excedentes nas famílias de agricultores e nas famílias pluriativas nos dois Estados, enfatizando a posse de poupança, o depósito em dinheiro e o investimento em outros negócios, nos últimos doze meses anteriores à data da entrevista. Na comparação dos dois Estados, entre as famílias pluriativas, percebeu-se uma diferença expressiva, comparando-se os gaúchos que possuem poupança $(84,6 \%)$ e os catarinenses $(41,7 \%)$, embora sejam muito próximas as proporções daqueles que depositaram algum dinheiro na poupança nos últimos doze meses. Além disso, ambos não diferem muito no que se refere a outros investimentos (construção de moradias, aquisição de imóveis, por exemplo), havendo apenas $15,4 \%$ de gaúchos e $20,8 \%$ de catarinenses que afirmaram realizar gastos em outros investimentos.

Tabela 28

CADERNETA DE POUPANÇA, DEPÓSITO DE DINHEIRO NOS ÚLTIMOS DOZE MESES E OUTROS INVESTIMENTOS DE FAMÍLIAS PLURIATIVAS EFAMÍLIAS DE AGRICULTORES NAS COMUNIDADES SELECIONADAS

\begin{tabular}{|c|c|c|c|c|c|c|c|c|c|c|}
\hline & \multicolumn{6}{|c|}{ (\%) Possui poupança $(\%)$ Depositou dinheiro } & \multicolumn{3}{|c|}{ (\%) Outro investimento } \\
\hline & & sim & não & $\mathrm{nr}$ & $\operatorname{sim}$ & não & $\mathrm{nr}$ & $\operatorname{sim}$ & não & $\mathrm{nr}$ \\
\hline \multirow{2}{*}{ Pluriativos } & $\mathrm{RS}$ & 84,6 & 15,4 & - & 46,2 & 53,8 & - & 15,4 & 46,2 & 38,5 \\
\hline & $\mathrm{SC}$ & 41,7 & 45,8 & 12,5 & 37,5 & 50,0 & 12,5 & 20,8 & 79,2 & - \\
\hline \multirow{2}{*}{ Agricultores } & $\mathrm{RS}$ & 70,0 & 30,0 & - & 30,0 & 70,0 & 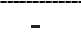 & 20,0 & 80,0 & - \\
\hline & $\mid \mathrm{SC}$ & 61,5 & 38,5 & - & 61,5 & 38,5 & - & 7,7 & 92,3 & - \\
\hline
\end{tabular}

Fonte: Pesquisa de campo (1998). 
No que se refere às famílias de agricultores, verifica-se que são relativamente similares as proporções de gaúchos $(70 \%)$ e catarinenses $(61,5 \%)$ que possuem caderneta de poupança. No entanto, o mesmo não ocorre em relação ao quesito seguinte, pois $61,5 \%$ das famílias de agricultores catarinenses declararam ter aplicado algum dinheiro nos últimos doze meses, ao passo que apenas $30 \%$ dos gaúchos o fizeram. Com relação ao investimento em outros imóveis, em ambos os locais são pouco expressivos os índices daqueles que realizam tais empreendimentos.

Ao se confrontar as famílias de agricultores e as famílias pluriativas a partir das informações obtidas através da pesquisa de campo, percebe-se que as famílias pluriativas catarinenses são os que possuem os índices mais baixos entre os que declararam possuir caderneta de poupança. Por outro lado, a maior freqüência de depósitos é realizada pelas famílias de agricultores catarinenses, que são justamente aqueles que possuem as maiores idades e cujas rendas oriundas de aposentadorias alcançam o índice mais elevado. Tal situação se deve ao fato de que essas famílias de agricultores, em sua ampla maioria, percebem aposentadorias de atividades não-agrícolas, no caso especifico advindas de seu emprego nas indústrias têxteis da região. Após conquistarem a aposentadoria, voltam a trabalhar exclusivamente na agricultura e a somar aos ganhos da atividade agrícola os benefícios previdenciários, o que em geral lhes garante um bom padrão de bem-estar.

Uma das formas para caracterizar a pluriatividade como uma estratégia de reprodução das unidades familiares é demonstrar as relações existentes entre a agricultura e as atividades não-agrícolas. Há, obviamente, diversos mecanismos de relacionamento entre estas duas esferas econômicas (a propriedade, de um lado, e o mercado, de outro), podendo-se afirmar que, em sua essência, trata-se das diferentes formas de interação da unidade de produção e da unidade doméstica com o ambiente em que se inserem as unidades familiares. Entretanto, é inegável que os mecanismos de alocação dos rendimentos obtidos pelos membros das famílias exercem um papel central sobre o modo pelo qual cada unidade gerencia os meios para garantir a sua reprodução social.

Um dos aspectos fundamentais à garantia da reprodução das unidades familiares, portanto, refere-se ao destino e à alocação dos resultados financeiros do trabalho. Trata-se, enfim, de saber quais são os alvos preferenciais das decisões de gasto e de investimento das famílias e de verificar quais são as diferenças entre as unidades familiares de agricultores e famílias pluriativas a este respeito. Aqui, a hipótese fundamental a ser esclarecida refere-se à influência dos rendimentos obtidos em atividades não-agrícolas sobre o processo produtivo e a unidade de produção como um todo. Na verdade, a interrogação central está em saber se a pluriatividade constitui-se em 
uma estratégia orientada para garantir a viabilização econômica das propriedades, frente às pressões externas, ou se decorre de uma opção voluntária e individual dos membros da famílias, que em muitos casos leva ao abandono da própria agricultura como atividade principal da unidade familiar.

Conforme salientado anteriormente, as unidades familiares agrícolas diferenciam-se fundamentalmente das unidades familiares pluriativas pela combinação de mais de uma atividade e, em decorrência, pela existência de mais uma fonte de rendimentos. Assim, iniciou-se a análise da alocação das entradas monetárias nas unidades familiares agrícolas e pluriativas pelas observação do destino dos recursos gerados pela agricultura. A metade (50\%) dos agricultores gaúchos entrevistados declarou, conforme mostra a Tabela 29, que o dinheiro ganho com essa atividade destinava-se à subsistência da família e outros $20 \%$ responderam que utilizavam a maior parte do dinheiro em medicamentos. Já os agricultores catarinenses componentes da amostra afirmaram que gastam suas receitas monetárias advindas da agricultura, em igual proporção, na subsistência e nas despesas pessoais.

Tabela 29

PRINCIPAL DESTINO DAS RECEITAS AGRÍCOLAS DAS FAMÍLIAS DEAGRICULTORES NAS COMUNIDADE SELECIONADAS

\begin{tabular}{|l|cc|cc|}
\hline \multirow{2}{*}{ Destino das receitas agrícolas } & \multicolumn{2}{|c|}{ RS } & \multicolumn{2}{c|}{ SC } \\
\cline { 2 - 5 } & $\mathrm{n}$ & $\%$ & $\mathrm{n}$ & $\%$ \\
\hline Investimentos na propriedade & 1 & 10,0 & - & - \\
Subsistência & 5 & 50,0 & 5 & 38,5 \\
Investimentos na propriedade e aumento & 1 & 10,0 & - & - \\
do conforto doméstico & - & - & 5 & 38,5 \\
Despesas pessoais de todo tipo & 2 & 20,0 & - & - \\
Medicamentos & 1 & 10,0 & - & - \\
Investimentos na propriedade & - & - & 2 & 15,4 \\
e subsistência & - & - & 1 & 7,7 \\
Não vende produtos agrícolas & 10 & 100,0 & 13 & 100,0 \\
Não sabe / não respondeu & \multicolumn{4}{|l}{} \\
\hline Total & \multicolumn{4}{|c|}{} \\
\hline
\end{tabular}

Fonte: Pesquisa de campo (1998).

Entre as famílias pluriativas, conforme indicado na Tabela 30, tanto na região da Encosta da Serra gaúcha como no Vale do Itajaí catarinense, o principal destino das receitas obtidas com as atividades agrícolas foi a ampliação das chances de subsistência (38,5\% e 41,7\%, respectivamente). A utilização 
dos ganhos nas atividades agrícolas e nos investimentos na propriedade, no caso gaúcho, equipara-se com o item anterior (38,5\%). Já em Braço do Sul, o dinheiro das receitas agrícolas também é destinado para as despesas pessoais $(29,2 \%)$.

Tabela 30

PRINCIPAL DESTINO DAS RECEITAS AGRÍCOLAS DAS FAMÍLIAS PLURIATIVAS NAS COMUNIDADE SELECIONADAS

\begin{tabular}{|c|c|c|c|c|}
\hline \multirow{2}{*}{ Destino das receitas agrícolas } & \multicolumn{2}{|c|}{$\mathrm{RS}$} & \multicolumn{2}{|c|}{ SC } \\
\hline & $\mathrm{n}$ & $\%$ & $\mathrm{n}$ & $\%$ \\
\hline Investimentos na propriedade & 3 & 23,1 & - & - \\
\hline Subsistência & 5 & 38,5 & 10 & 41,7 \\
\hline Aumento do conforto da casa & - & - & - & - \\
\hline $\begin{array}{l}\text { Investimento na propriedade e aumento } \\
\text { do conforto doméstico }\end{array}$ & 5 & 38,5 & 1 & 4,2 \\
\hline Despesas pessoais & - & - & 7 & 29,2 \\
\hline Não há renda agrícola & - & - & 6 & 25,0 \\
\hline Total & 13 & 100 & 24 & 100 \\
\hline
\end{tabular}

Fonte: Pesquisa de campo (1998).

Além dos ganhos financeiros oriundos das atividades agrícolas, as famílias pluriativas também contam com as entradas monetárias advindas das atividades não-agrícolas, conforme indica a Tabela 31. Neste caso, poder-se-á verificar qual o destino dos rendimentos obtidos nessas atividades. Em ambos os Estados, os dados da pesquisa de campo revelam que estas receitas destinam-se prioritariamente às despesas com a subsistência dos membros pertencentes ao núcleo familiar (38,5\% no caso gaúcho e $50 \%$ entre os catarinenses). Além de serem utilizados na subsistência, esses recursos também são destinados a outros itens, como despesas pessoais (33,3\% em Santa Catarina), investimentos e conforto domésticos (15,4\% em Padre Eterno e 8,3\% em Braço do Sul). 


\section{Tabela 31}

PRINCIPALDESTINO DAS RECEITAS NÃO-AGRÍCOLAS DAS FAMÍLIAS PLURIATIVAS NAS COMUNIDADES SELECIONADAS

\begin{tabular}{|l|cc|cc|}
\hline \multirow{2}{*}{ Destino das receitas não-agrícolas } & \multicolumn{2}{|c|}{ RS } & \multicolumn{2}{c|}{ SC } \\
\cline { 2 - 5 } & $\mathrm{n}$ & $\%$ & $\mathrm{n}$ & $\%$ \\
\hline Investimentos na propriedade & - & - & 1 & 4,2 \\
Subsistência & 5 & 38,5 & 12 & 50,0 \\
Aumento do conforto da casa & 2 & 15,4 & 1 & 4,2 \\
Investimento na propriedade e aumento & 2 & 15,4 & 2 & 8,3 \\
do conforto doméstico & 2 & 15,4 & 8 & 33,3 \\
Despesas pessoais & 2 & 15,4 & - & - \\
Estudo dos filhos & 13 & 100,0 & 24 & 100,0 \\
\hline Total & \multicolumn{3}{|c|}{} \\
\hline
\end{tabular}

Fonte: Pesquisa de campo (1998).

Além de investigar o destino dos rendimentos obtidos com as atividades agrícolas e não-agrícolas das unidades familiares, também se buscou averiguar de que forma foram divididas essas entradas financeiras no interior do núcleo familiar. De certo modo, a repartição dos bens entre os membros que compõe o núcleo doméstico também expressa determinado tipo de relações de poder e de hierarquia familiar. Trata-se, nesse caso, das relações de gênero, que em geral caracterizam as famílias de agricultores ou camponeses, tal como já foi analisado por Carneiro $(1987,1998)$ e Woortmann (1995).

Em relação aos casos estudados, os resultados, sintetizados na Tabela 32, demonstraram que tanto nas famílias de agricultores como nas famílias pluriativas as receitas oriundas das atividades agrícolas em geral são centralizados e administrados pelos pais. Em Padre Eterno Ilges, em ambos os tipos de unidades familiares, em torno de $70 \%$ dos entrevistados responderam que são os pais (chefes e cônjuges) que realizam a gestão do dinheiro. Vale a pena chamar a atenção para o fato de que é o casal e não apenas o chefe quem executa estas tarefas (apenas aproximadamente $20 \%$,- em todos os casos - afirmaram que administrar o dinheiro é tarefa exclusiva dos chefes). Em Braço do Sul, as proporções de famílias de agricultores e famílias pluriativas nas quais são os pais os responsáveis pela centralização do dinheiro também constituem a maioria,embora sejam bastante inferiores em relação ao caso gaúcho. Contudo, os índices das famílias de agricultores e famílias pluriativas que declararam não haver receitas agrícolas também mostraram-se bastante elevados no caso catarinense (quase $25 \%$, na média). No caso dos pluriativos, a inexistência de ganhos com as atividades agrícolas pode ser explicada pelo fato de que sua produção agrícola des- 
tina-se, prioritariamente, ao autoconsumo e não ao comércio, conforme já analisado anteriormente. Já a situação dos $23,1 \%$ de agricultores que declararam não ter receitas agrícolas pode ser compreendida se for considerado tratar-se de famílias constituídas somente pelos cônjuges, que são aposentados e a maioria com idade acima dos 60 anos. Portanto, não causa nenhuma surpresa que não vendam quase nada de sua produção agrícola, que se destina quase exclusivamente ao autoconsumo.

Tabela 32

FORMADE DIVISÃO DAS RECEITAS AGRÍCOLAS DAS FAMÍLIAS DE AGRICULTORESE DAS FAMÍLIAS PLURIATIVAS NASCOMUNIDADES SELECIONADAS

\begin{tabular}{|l|cc|cc|}
\hline \multirow{2}{*}{ Forma da divisão das receitas agrícolas } & \multicolumn{3}{|c|}{ Agricultores (\%) } & \multicolumn{3}{|c|}{ Pluriativos (\%) } \\
\cline { 2 - 6 } & RS & SC & RS & SC \\
\hline O chefe centraliza os rendimentos & 20,0 & 23,1 & 15,4 & 20,8 \\
O casal centraliza todas as entradas & 70,0 & 23,1 & 69,2 & 37,5 \\
e divide conforme sua decisão & & & & \\
Cada um fica com a parte que ganha & - & - & 7,7 & 8,3 \\
$\begin{array}{l}\text { e os pais sustentam a casa e a família } \\
\text { São divididas entre quem trabalha } \\
\text { na propriedade de forma igual }\end{array}$ & 10,0 & 23,1 & - & 4,2 \\
Não há rendimentos de atividade agrícolas & - & 23,1 & 7,7 & 25,0 \\
Não sabe/não respondeu & - & 7,7 & - & 4,2 \\
\hline Total & 100,0 & 100,0 & 100,0 & 100,0 \\
\hline
\end{tabular}

Fonte: Pesquisa de campo (1998).

No que se refere à forma de divisão e à gestão das receitas não-agrícolas entre as famílias de pluriativos, cujas informações estão sintetizadas na Tabela 33, observa-se uma heterogeneidade bastante acentuada. Contudo, é possível notar que as proporções mais significativas são relacionadas à centralização dos rendimentos nas mãos do chefe, como é o caso dos pluriativos catarinenses, em que a metade (50\%) dos entrevistados identificou essa forma, ou é gerida pelos pais, como no caso dos $38,5 \%$ de pluriativos gaúchos. $\mathrm{Na}$ localidade de Padre Eterno Ilges, também se registrou uma significativa proporção de unidades familiares pluriativas $(30,8 \%)$, cujos membros que trabalham em atividades não-agrícolas retêm consigo todos os rendimentos obtidos, sem repassar nenhuma parcela aos pais. Outra forma de divisão das receitas, que é relativamente usual entre os pluriativos catarinenses $(25 \%)$ e em menor escala no Rio Grande do Sul $(15,4 \%)$, é aquela em que há repartição 
dos rendimentos obtidos em atividades não-agrícolas mediante a contribuição dos membros que trabalham fora com o pagamento de algumas despesas domésticas (em geral, energia elétrica, gêneros alimentícios, entre outras). A divisão total de todas as entradas monetárias familiares entre todos os membros também ocorre nos dois casos investigados, porém em proporções bem mais modestas (15,4\% em Padre Eterno Ilges e 8,3\% em Braço do Sul).

\section{Tabela 33}

FORMADE DIVISÃO DAS RECEITAS NÃO-AGRÍCOLAS DAS FAMIILIAS PLURIATIVAS NAS COMUNIDADES SELECIONADAS

\begin{tabular}{|l|cc|}
\hline \multirow{2}{*}{ Forma da divisão das receitas não-agrícolas } & \multicolumn{3}{|c|}{ Pluriativos } \\
\cline { 2 - 2 } & $\mathrm{RS}$ & $\mathrm{SC}$ \\
\hline $\begin{array}{l}\text { O chefe centraliza todos os rendimentos } \\
\text { O casal centraliza todas as rendas e as }\end{array}$ & - & 50,0 \\
divide conforme sua decisão & 38,5 & - \\
$\begin{array}{l}\text { Os que trabalham fora ficam com dinheiro, } \\
\text { mas contribuem em algumas despesas }\end{array}$ & 15,4 & 25,0 \\
$\begin{array}{l}\text { Os que trabalham fora ficam com o dinheiro } \\
\text { que ganham e não contribuem com despesas }\end{array}$ & 30,8 & 4,2 \\
$\begin{array}{l}\text { Aqueles que trabalham fora entregam parte } \\
\text { do dinheiro aos pais e ficam com o restante }\end{array}$ & - & 8,3 \\
$\begin{array}{l}\text { Os rendimentos são divididos entre todos } \\
\text { os membros da família que trabalham }\end{array}$ & 15,4 & 8,3 \\
Não sabe/Sem resposta & - & 4,2 \\
\hline Total & 100 & 100 \\
\hline
\end{tabular}

Fonte: Pesquisa de campo (1998).

\subsection{PLURIATIVIDADE: UMAOPÇÃO INDIVIDUAL EMBUSCA DE UMESTILO DE VIDA?}

O estudo da pluriatividade na perspectiva da agricultura familiar constitui-se em um fenômeno que se reveste de várias particularidades, sendo uma destas o indivíduo que a exerce. As características das famílias pluriativas podem mudar de acordo com o sexo e a posição do indivíduo na hierarquia familiar. Mais do que isto, o próprio sentido da pluriatividade pode ser diferente, pois a opção por um trabalho fora do estabelecimento agrícola pode não ser decorrente de uma contingência econômica ou social, mas, ao contrário, uma opção espontânea dos indivíduos que integram a família. Para verificar quem são, o que pensam e qual o papel dos indivíduos que exercem a combinação de duas ou mais atividades, realizou-se a aplicação de questionário jun- 
to aos membros das famílias pluriativas que trabalham em atividades não-agrícolas, dentro ou fora da propriedade. Para evitar qualquer tipo de confusão esses indivíduos serão denominadas de "indivíduos pluriativos".

A aplicação dos questionários foi realizada simultaneamente ao momento das visitas às famílias pluriativas, quando foram então preenchidos dois formulários distintos, um destinado a coletar informações sobre a família e o outro orientado especificamente para os indivíduos que exerciam a pluriatividade no momento da entrevista. Deste modo, foram aplicados 29 questionários, constituindo o grupo de indivíduos pluriativos, sendo 13 no Rio Grande do Sul (em Padre Eterno Ilges) e 16 em Santa Catarina (em Braço do Sul). No caso gaúcho, foi realizado o mesmo número de entrevistas entre famílias e indivíduos pluriativos mas, em Blumenau, pelo fato da amostra das famílias pluriativas abarcar um número maior de casos, optou-se por entrevistar 16 indivíduos (embora tenham sido visitadas e entrevistadas o total de 23 famílias de pluriativos).

A idéia de realizar um levantamento de dados com os membros das famílias pluriativas que efetivamente exercem as atividades não-agrícolas, dentro ou fora da propriedade, também teve por objetivo ampliar as informações sobre as relações intrafamiliares, sobre a hierarquia familiar e sobre as relações de gênero e de parentesco vigentes no âmbito familiar e doméstico. Contudo, não se trata de buscar informações para realização de um estudo propriamente etnográfico da família ou do parentesco e suas influências sobre a organização do processo produtivo e da pluriatividade. Esta perspectiva, que já foi perseguida e alcançada com sucesso em alguns estudos, destacando-se aqueles realizados por Carneiro (1998) e Woortmann (1995), entre outros, exigiria a demarcação de um outro enfoque analítico.

Uma das principais características dos indivíduos pluriativos entrevistados é que são particularmente jovens, em sua grande maioria com idades entre $19 \mathrm{e}$ 34 anos (51,7\% do total entrevistado), e solteiros (85,7\% no Rio Grande do Sul e $62,5 \%$ em Santa Catarina). Somente 31\% deles situa-se na faixa etária entre 35 e 59 anos. Entre estes últimos, a maioria é formada de casados (todos no caso gaúcho e 66,7\% em Braço do Sul).Apesar de mais jovens e com maiores oportunidades para estudar os indivíduos pluriativos repetem os baixos índices de escolaridade registrados em relação às famílias, pois 61,5\% dos indivíduos pluriativos de Padre Eterno Ilges e 81,3\% de Braço do Sul freqüentaram a escola somente para preencher o ensino fundamental, pois não chegaram a concluir o primeiro grau.As mulheres possuem escolaridade ainda mais baixa do que os homens, pois todas afirmaram ter freqüentado a escola apenas por alguns poucos anos. 
Tabela 34

IDADE E SEXODOS INDIVÍDUOS PLURIATIVOS ENÚMEROTOTAL

DE MEMBROS QUE COMPÕEM ESTAS FAMÍLIAS

NAS COMUNIDADES SELECIONADAS

\begin{tabular}{|l|cc|cc|cc|c|}
\hline \multirow{3}{*}{ Idade (anos) } & \multicolumn{4}{|c|}{ Sexo (n) } & \multirow{2}{*}{ Total } & Total \\
\cline { 2 - 7 } & Masculino & Feminino & & Geral \\
\cline { 2 - 7 } & RS & SC & RS & SC & RS SC & \\
\hline 10 a 18 & 2 & - & 1 & 2 & 3 & 2 & 5 \\
19 a 34 & 5 & 6 & 2 & 2 & 7 & 8 & 15 \\
35 a 59 & 1 & 2 & 2 & 4 & 3 & 6 & 9 \\
\hline Total de pessoas & 8 & 8 & 5 & 8 & 13 & 16 & 29 \\
\hline
\end{tabular}

Fonte: Pesquisa de campo (1998).

Entre as características mais salientes dos indivíduos pluriativos ocupados em atividades não-agrícolas está o baixo índice de profissionalização. Mais da metade $(51,7 \%)$ jamais havia trabalhado em outra atividade profissional. Em muitos casos, são as próprias empresas que buscam esta "inexperiência da força de trabalho". Entre as vantagens para a contratação deste tipo de mão-de-obra, ressaltam os contratantes o fato de serem trabalhadores jovens permitir um treinamento diretamente relacionado às necessidades específicas das indústrias, facilitando a formação de uma força de trabalho quase cativa, disciplinada e fortemente identificada com os objetivos da empresa. Em Padre Eterno Ilges, todos os entrevistados responderam que não realizaram nenhum tipo de treinamento para obter seu atual emprego. Já em Braço do Sul, encontrou-se uma parcela de $37,5 \%$ do total de pluriativos que receberam algum tipo de treinamento para iniciar suas novas ocupações

Além dessa vantagem, as empresas levam em consideração dois outros elementos para privilegiar a contratação dos jovens filhos de agricultores. Uma delas é o fato do salário pago ser muito inferior, em comparação com aqueles recebidos pelos trabalhadores já profissionalizados. A outra vantagem está em contratar um tipo de mão-de-obra que oferece menos resistência organizativa às normas impostas pelo trabalho fabril, sendo considerado um aspecto positivo o fato de serem indivíduos jovens e sem experiência de trabalho anterior, permitindo um melhor envolvimento dos trabalhadores com o "espírito da empresa". Em muitas das indústrias visitadas durante a pesquisa de campo, foi possível constatar que tanto no Rio Grande do Sul como em Santa Catarina há um estímulo ao senso de colaboração e mutualidade dos funcionários, o que resulta em uma forma de canalização da participação, que, ao invés de guiar-se para as agremia- 
ções sindicais de classe, acaba esgotando-se nas atividades recreativas, esportivas e de lazer, organizadas no interior da própria empresa.

Em muitas das pequenas localidades visitadas na região da Encosta da Serra gaúcha e do Vale do Itajaí catarinense, verifica-se a presença de apenas uma ou no máximo duas empresas. Assim, os funcionários acabam não sendo apenas colegas de trabalho, pois entre si vigoram também, e ao mesmo tempo, relações de vizinhança e parentesco, fazendo com que nesses pequenos povoados as relações de sociabilidade e de interconhecimento, para usar um termo cunhado por Mendras (1978), sejam intensas. Dentro das empresas não vigoram apenas as relações de trabalho, mas os códigos e as normas sociais às quais todas as pessoas da comunidade local são conformadas. Neste sentido, poder-se-ia falar inclusive em uma transposição e reinvenção de certas características socioculturais, típicas das sociedades camponesas, pelos novos ambientes de trabalho das indústrias. Essa inter-relação das indústrias com o ambiente social e econômico local parece constituir-se em uma característica típica de regiões que conheceram processos de industrialização difusa ou foram afetadas pelas estratégias de descentralização das empresas situadas em ambientes urbanos próximos, como é o caso aqui tratado.

Outra característica dos indivíduos pluriativos está no fato de residirem em estabelecimentos situados nas áreas rurais. Na localidade de Padre Eterno Ilges, na região da Encosta da Serra no Rio Grande do Sul, existe uma indústria situada no centro do povoado, próxima a um salão de festas, um campo de futebol e uma igreja. Em seu entorno situam-se as propriedades dos agricultores, cujos membros trabalham nessa empresa. No entanto, boa parte da mão-de-obra utilizada por essa indústria desloca-se de outros povoados situados na região, para completar o quadro de funcionários. Já em Santa Catarina, conforme já mencionado anteriormente, a localidade pesquisada, Braço do Sul, situa-se a alguns quilômetros do centro do distrito de Vila Itoupava, onde encontramse algumas das indústrias que empregam os pluriativos. No entanto, a exemplo do que ocorre no caso gaúcho, os indivíduos pluriativos que residem em Braço do Sul também se deslocam para outras localidades e municípios da região, como as cidades de Massaranduba, Pomerode, Gaspar e Luís Alves.

Entre os indivíduos pluriativos que foram entrevistados, o setor econômico em que a maioria estava ocupado é a indústria, sendo 84,6\% em Padre Eterno Ilges e $81,25 \%$ em Braço do Sul, conforme mostra a Tabela 35. Considerando-se o fato do mercado de trabalho, em ambas as regiões, ser amplamente dominado pelas atividades industriais, a forte concentração dos pluriativos neste setor apenas vem corroborar este predomínio. 
Essa ocupação dos pluriativos em atividades do setor industrial não apresenta diferenças significativas segundo o sexo dos indivíduos, pois a proporção de homens e mulheres que trabalham nessas atividades é muito próxima.

Tabela 35

SETORES DEATIVIDADES DOS INDIVÍDUOS PLURIATIVOS, SEGUNDOSEXO, NAS COMUNIDADES SELECIONADAS

\begin{tabular}{|l|cc|cc|cc|}
\hline \multirow{2}{*}{ Setores de atividades } & \multicolumn{3}{|c|}{ Masculino (\%) } & \multicolumn{2}{|c|}{ Feminino (\%) } & \multicolumn{2}{|c|}{ Total (\%) } \\
\cline { 2 - 7 } & $\mathrm{RS}$ & SC & RS & SC & RS & SC \\
\hline Indústria & 87,5 & 75,0 & 80,0 & 87,5 & 84,6 & 81,25 \\
Comércio & - & 12,5 & - & - & & 6,25 \\
Serviços auxiliares ativ. eco. & - & 12,5 & - & - & & 6,25 \\
Prestação serviços & 12,5 & - & - & - & 7,7 & \\
Serviços pessoais & - & - & - & 12,5 & - & 6,25 \\
Transformação artesanal & - & - & 20,0 & - & 7,7 & \\
\hline Total & 100,0 & 100,0 & 100,0 & 100,0 & 100,0 & 100,0 \\
\hline
\end{tabular}

Fonte: Pesquisa de campo (1998).

Uma variável econômica ainda escassamente detalhada pelas pesquisas sobre a pluriatividade refere-se a renda dos indivíduos pluriativos. A Tabela 36 apresenta as rendas dos pluriativos, em salários mínimos, obtidas com as atividades não-agrícolas que exerciam por ocasião da entrevista. Como se percebe, a grande maioria dos pluriativos declarou receber rendimentos que se enquadram nas faixas de 1 a 2 salários mínimos: 69,2\%, no caso dos pluriativos gaúchos, e 31,3\% em Braço do Sul. No caso catarinense, os rendimentos parecem ser um pouco superiores, pois $43,8 \%$ dos entrevistados declararam que recebem em torno de 2 a 3 salários mínimos. As remunerações recebidas pelos membros do sexo masculino são superiores aos auferidos pelas mulheres, especialmente no caso de Braço do Sul, onde 37,5\% dos homens recebem acima de 4 salários mínimos, ao passo que os pluriativos de sexo feminino não ultrapassam a faixa de renda situada entre 2 e 3 salários. Mas é na faixa de até 2 salários mínimos que se percebe mais nitidamente a desproporção dos rendimentos segundo o sexo dos pluriativos. Entre os homens são $62,5 \%$ dos gaúchos e 12,5\% dos catarinenses que recebem até 2 salários mínimos. Já entre as mulheres, $100 \%$ das gaúchas e $62,5 \%$ das catarinenses ganham até 2 salários mínimos. 
Tabela 36

RENDAMENSALDOS INDIVÍDUOS PLURIATIVOS, SEGUNDOSEXO (SALÁRIOS MÍNIMOS), NAS COMUNIDADES SELECIONADAS

\begin{tabular}{|c|cc|cc|cc|}
\hline Salários & \multicolumn{2}{c|}{ (\%) Masculino } & \multicolumn{2}{c|}{ (\%) Feminino } & \multicolumn{2}{c|}{ (\%) Total } \\
mínimos & RS & SC & RS & SC & RS & SC \\
\hline Até 1 & - & - & 20,0 & 12,5 & 7,7 & 6,3 \\
1 a 2 & 62,5 & 12,5 & 80,0 & 50,0 & 69,2 & 31,3 \\
2 a 3 & 25,0 & 50,0 & - & 37,5 & 15,4 & 43,8 \\
3 a 4 & 12,5 & - & - & - & 7,7 & - \\
4 a 5 & - & 12,5 & - & - & - & 6,3 \\
5 a 6 & - & 12,5 & - & - & - & 6,3 \\
9 a 10 & - & 12,5 & - & - & - & 6,3 \\
\hline Total & 100 & 100 & 100 & 100 & 100 & 100 \\
\hline
\end{tabular}

${ }^{1}$ Um salário mínimo equivalia a R \$ 130,00, em setembro de 1998, quando foi realizada a pesquisa de campo.

Fonte: Pesquisa de campo (1998).

No entanto, o que precisa ser ainda melhor conhecido e avaliado é o efeito dessas rendas sobre o orçamento doméstico e qual a sua relação com a manutenção e a reprodução da unidade produtiva agrícola, a partir da ótica e das considerações dos próprios membros que exercem essa pluriatividade. Conforme já apontado, é analiticamente não-recomendável desvincular o indivíduo pluriativo da unidade de análise-chave, isto é, da família, para entender a pluriatividade. Ao contrário, trata-se de conhecer os mecanismos e o modo de funcionamento que se estabelecem entre os indivíduos pluriativos e suas respectivas famílias. Para tanto, foram escolhidos alguns indicadores, tais como a forma de uso do dinheiro obtido nas atividades não-agrícolas e as ajudas fornecidas pelos pluriativos às suas famílias, que se acredita possam dar visibilidade a esses mecanismos e estratégias que caracterizam a interrelação dos indivíduos pluriativos com suas famílias.

A Tabela 37, a seguir, informa os principais destinos dos rendimentos dos indivíduos pluriativos entrevistados na pesquisa de campo.É curioso notar, por exemplo, que apenas um pluriativo (gaúcho) declarou ter despesas com o pagamento de aluguel (e que esta despesa representava $15 \%$ de sua renda total). Isso leva a suspeitar que entre os indivíduos pluriativos as despesas com moradia são muito baixas ou praticamente inexistentes, o que se explica pelo fato destes indivíduos residirem na casa dos pais ou em habitação própria. Entre os itens de maior frequiência dos gastos encontram-se as despesas com roupas e vestuário, para os quais são alocados em torno de $15 \%$ das rendas dos indivíduos pluriativos. Embora com freqüências oscilantes (número de indivíduos que realiza de- 
terminado gasto) as despesas com atividades de lazer e manutenção de veículo ou transporte também atingem proporções pouco abaixo de $20 \%$. A alimentação absorve cerca de $30 \%$ dos recursos daqueles que têm despesa com este item, pois no Rio Grande do Sul apenas quatro pluriativos declaram que possuem gastos com alimentação. Isto demonstra que a unidade agrícola em que residem os indivíduos pluriativos cumpre, de fato, o papel de rebaixar os custos de reprodução da força de trabalho, uma vez que a grande maioria não paga em dinheiro os alimentos que são produzidos na propriedade pelos seus familiares, embora preste ajudas ou auxílios na execução de tarefas dentro da propriedade

Tabela 37

FORMA DEUTILIZAÇÃODOS RENDIMENTOS DOS INDIVÍDUOS PLURIATIVOS (VALORES MÉDIOS) NAS COMUNIDADES SELECIONADAS ${ }^{1}$

\begin{tabular}{|l|c|c|c|c|}
\hline \multirow{2}{*}{ Tipo de despesa ou gasto } & \multicolumn{2}{|c|}{ RS } & \multicolumn{2}{c|}{ SC } \\
\cline { 2 - 5 } & $\mathrm{n}$ & $\%$ & $\mathrm{n}$ & $\%$ \\
\hline Aluguel ou alojamento & 1 & 15,00 & - & - \\
Ajuda para família & 4 & 26,25 & 10 & 19,40 \\
Gastos com alimentação & 4 & 27,5 & 12 & 34,75 \\
Gastos com roupas e vestuários em geral & 11 & 16,36 & 14 & 16,43 \\
Atividade de lazer & 7 & 15,00 & 14 & 12,43 \\
Pagto. de prestações referentes a aquisição & 5 & 36,00 & 4 & 31,50 \\
de bens (imóveis, mobília, etc.) & & & & \\
Gastos com ensino e/ou educação & 3 & 43,3 & 1 & 30,00 \\
Despesas com veículo e/ou transporte & 3 & 18,3 & 7 & 18,57 \\
Pagamento de pensão & & - & 1 & 35,00 \\
Pagamento de taxas e/ou impostos & & - & 1 & 18,00 \\
Repassa toda a renda aos pais & 2 & 100,0 & - & - \\
Coloca o dinheiro na poupança & 4 & 38,75 & 4 & 42,00 \\
Outros & 3 & 21,7 & 5 & 14,60 \\
\hline
\end{tabular}

${ }^{1}$ Questão de resposta múltipla.

Fonte: Pesquisa de campo (1998).

Esse comprometimento relativamente baixo dos orçamentos dos indivíduos pluriativos com moradia, alimentação, transporte e vestuário favorece o investimento de parcela significativa de suas rendas no pagamento de prestações referentes à aquisição de bens de consumo duráveis, sobretudo eletrodomésticos e veículos. Nos dois casos estudados, em torno de um terço dos indivíduos pluriativos entrevistados declararam que gastam mais de $30 \%$ de suas rendas no pagamento de prestações decorrentes das compras à prazo. Esta informação revela que o poder de compra dos pluriativos, tendo em vista a regularidade 
de seus ganhos, pode estimular o desenvolvimento de um mercado local de consumo. Também por esta via pode-se explicar o fato dos pluriativos terem um papel significativo na cobertura das despesas familiares (cerca de $26,25 \%$ das rendas dos gaúchos e 19,4\% dos catarinenses, ainda que, nesse caso, o montante é bem superior aos anteriores), no próprio investimento educacional e, o que é mais importante, destinando em média $40 \%$ de suas rendas para a poupança.

A análise dessas questões parece ser fundamental para se compreender o significado da pluriatividade para os indivíduos e para as famílias. Nesse caso, pode-se estabelecer pelos menos três possibilidades explicativas: primeiramente, que a pluriatividade pode constituir-se em uma estratégia, tão-somente, de reprodução da família e da unidade doméstica; a segunda alternativa remete a outro objetivo - a pluriatividade pode apresentar-se como um mecanismo destinado predominantemente a retomar ou modernizar a unidade de produção; terceiro, que as duas opções anteriores são complementares e que a pluriatividade signifique ambas as possibilidades.

Para detalhar melhor as relações entre os indivíduos pluriativos e a unidade de produção agrícola (ou o estabelecimento em que residem com sua família), foram investigados os mecanismos de alocação das rendas obtidas nas atividades não-agrícolas. No caso gaúcho há uma divisão relativamente homogênea entre aqueles que entregam parte de seus rendimentos ao pais (que constituem 46,2\%) e os que retêm o conjunto das rendas exclusivamente para si (somam 53,8\% dos casos). Já em Braço do Sul, são apenas 18,7\% os indivíduos pluriativos que repassam parte de seus ganhos aos pais, pois a grande maioria $(81,3 \%)$ declarou que não realiza nenhum tipo de repasse aos patriarcas. Entretanto, apesar da maioria dos indivíduos pluriativos não entregar diretamente aos pais as rendas obtidas com as atividades não-agrícolas, a grande maioria informou que presta algum tipo de "ajuda financeira" à família, o que, muitas vezes, ocorre pela aquisição de gêneros alimentícios, pagamentos de taxas ou impostos, entre outras possibilidades.

Outra informação refere-se à forma de utilização ou alocação das rendas não-agrícolas. Conforme mencionado anteriormente, há vários estudos sobre a pluriatividade que destacaram a importância das rendas nãoagrícolas para viabilizar a retomada ou a sustentação da unidade de produção (Hespanha, 1995; Reis, Hespanha, Pires, Jacinto, 1990). Outros, no entanto, enfatizaram muito mais o papel da pluriatividade na ampliação do conforto doméstico e da inserção da família no mercado de consumo (Barlett, 1986). Nos casos aqui estudados, as rendas provenientes das atividades não-agrícolas, em geral, não são utilizadas para investir na propriedade ou na agricultura. Em Padre Eterno Ilges, 30,8\% dos indivíduos pluriativos entrevistados ainda afirmaram destinar parcela de suas rendas para aper- 
feiçoar ou manter seus sistemas agrícolas, mas em Braço do Sul apenas 18,7\% responderam positivamente a essa questão.

Tabela 38

ALOCAÇÃO DAS RENDAS DOS INDIVÍDUOS PLURIATIVOS

NAAGRICULTURAOU DENTRODAPROPRIEDADE NAS COMUNIDADES SELECIONADAS

\begin{tabular}{|l|cc|cc|}
\hline Alocação das rendas & \multicolumn{2}{|c|}{ RS } & \multicolumn{2}{c|}{ SC } \\
\cline { 2 - 5 } na propriedade & $n$ & $\%$ & n & $\%$ \\
\hline Sim & 4 & 30,8 & 3 & 18,7 \\
Não & 9 & 69,2 & 13 & 81,3 \\
\hline Total & 13 & 100 & 16 & 100 \\
\hline
\end{tabular}

Fonte: Pesquisa de campo (1998).

A parcela das rendas não-agrícolas destinadas ao investimento na agricultura pelos indivíduos pluriativos são utilizadas para aquisição de implementos (especialmente no caso catarinense, na proporção de 66,7\%) ou, como ocorre em Padre Eterno Ilges, onde são usadas na aquisição de insumos (75\%) como adubos e defensivos. Apesar dessa pequena alocação de recursos financeiros, os pluriativos ajudam a organizar e auxiliam diretamente na agricultura. A participação dos indivíduos pluriativos nas tarefas realizadas no interior das propriedades varia de frequiência, ocorrendo diariamente em 25\% dos entrevistados (Santa Catarina) e "periodicamente" em 72,7\% dos entrevistados gaúchos e 43,8\% de catarinenses.A freqüência diária verificada em Braço do Sul provavelmente está relacionada ao fato de que no Vale do Itajaí as jornadas de trabalho dos pluriativos se alternam em diferentes turnos do dia, havendo um significativo número de trabalhadores que trabalham à noite, permitindo que utilizem pelo menos meio turno diário para dedicar-se às atividades agrícolas. Em Padre Eterno Ilges, essa situação é menos usual, pois a maioria das indústrias e mesmo as atividades de prestação de serviços funcionam somente durante o dia. O auxílio realizado de forma "periódica" é aquele que ocorre de forma esporádica ou em situações indefinidas. Nesse item, muitos entrevistados responderam que ajudavam nas tarefas agrícolas sempre que "sobrava algum tempo", condição que às vezes dependia do transporte do trabalho até o domicílio ou dos compromissos com outras atividades, geralmente as ocupações domésticas. Em geral, essa periodicidade era semanal, ou seja, pelo menos uma vez por semana os indivíduos pluriativos auxiliavam nas atividades agrícolas da propriedade. 
Tabela 39

FREQÜÊNCIACOMQUE OS INDIVÍDUOS PLURIATIVOS AUXILIAM

NAS ATIVIDADES AGRÍCOLAS DENTRODAPROPRIEDADE NAS COMUNIDADES SELECIONADAS

\begin{tabular}{|l|cc|cc|}
\hline Ajuda dos pluriativos & \multicolumn{2}{|c|}{ RS } & \multicolumn{2}{c|}{ SC } \\
\cline { 2 - 5 } na agricultura & $\mathrm{n}$ & $\%$ & $\mathrm{n}$ & $\%$ \\
\hline Diariamente & - & - & 4 & 25,0 \\
Periodicamente & 8 & 72,7 & 7 & 43,8 \\
Às vezes & 3 & - & 5 & 31,3 \\
\hline Total & 11 & 100,0 & 16 & 100,0 \\
\hline
\end{tabular}

Fonte: Pesquisa de campo (1998).

Além dessas características mais gerais sobre os indivíduos que exercem a pluriatividade, uma das dimensões ainda pouco estudadas refere-se às representações e às motivações pessoais dos indivíduos pluriativos, quando confrontados com a sua condição social e as características de seu trabalho. Trata-se, portanto, dos juízos valorativos que orientam as decisões subjetivas e as atitudes dos indivíduos pluriativos perante questões objetivas como, por exemplo, optar entre permanecer ou não na agricultura.

Segundo os indivíduos pluriativos entrevistados, a principal razão para o abandono da agricultura como atividade econômica são as motivações de ordem financeira, conforme opinaram 69,2\% dos entrevistados em Padre Eterno Ilges, e 93,8\% em Braço do Sul. Essa informação parece indicar que há uma relação estreita entre a baixa rentabilidade da agricultura e a decisão de recorrer a um novo tipo de inserção profissional através da pluriatividade.

Tabela 40

PRINCIPAIS MOTIVOS QUE LEVARAM OS INDIVÍDUOS PLURIATIVOS A BUSCAR UMA ATIVIDADE NÃO-AGRÍCOLA NAS COMUNIDADES SELECIONADAS

\begin{tabular}{|l|c|c|c|}
\hline \multirow{2}{*}{ Principais motivações } & \multicolumn{4}{|c|}{ \% indivíduos pluriativos } \\
\cline { 2 - 4 } & RS & SC & Total \\
\hline Buscar um trabalho mais & 7,7 & - & 3,4 \\
fácil que o agrícola & & & \\
Motivos financeiros & 69,2 & 93,8 & 82,8 \\
Motivos pessoais & 15,4 & 6,3 & 10,3 \\
Sem resposta & 7,7 & - & 3,4 \\
\hline Total & 100,0 & 100,0 & 100,0 \\
\hline
\end{tabular}

Fonte: Pesquisa de campo (1998). 
As motivações financeiras individuais, que fazem com que os pluriativos troquem a agricultura pelas atividades não-agrícolas, parecem estar em consonância com a queda geral da rentabilidade do setor agrícola do Brasil. Contudo, não foi somente devido à queda dos rendimentos agrícolas que os jovens se voltaram crescentemente para essas novas ocupações. Nos dados coletados junto às famílias de agricultores e famílias pluriativas, em que geralmente o entrevistado era o chefe da família, foram introduzidas questões opinativas acerca das motivações dos jovens em relação à atividade agrícola. Nas famílias de agricultores, conforme indica a Tabela 41, o entrevistado era perguntado sobre as expectativas quanto à permanência dos jovens na atividade agrícola. Conforme indicam os resultados, entre as famílias de agricultores gaúchos, $30 \%$ declararam que a permanência junto à família podia ser considerada como estímulo à permanência dos jovens. Outros $20 \%$ do total de respondentes acreditam que a residência na propriedade, as próprias dificuldades de viver na cidade ou porque consideraram "ser bom viver na agricultura" constituem-se em algumas das principais motivações que retêm os jovens na agricultura.

\section{Tabela 41 \\ MOTIVAÇÕES DOS JOVENS PLURIATIVOS PARA NÃO PERMANECER NA AGRICULTURA NAS COMUNIDADES SELECIONADAS}

\begin{tabular}{|l|cc|cc|}
\hline \multirow{2}{*}{\multicolumn{1}{|c|}{ Motivações dos jovens pluriativos }} & \multicolumn{2}{|c|}{ RS } & \multicolumn{2}{c|}{ SC } \\
\cline { 2 - 5 } & n & $\%$ & n & $\%$ \\
\hline Não pode desmatar para plantar & - & & 10 & 41,6 \\
Baixos preços dos produtos agrícolas & 3 & 23,0 & 3 & 12,5 \\
Renda baixa & 6 & 46,0 & 8 & 33,3 \\
Penosidade do trabalho agrícola & 1 & 7,7 & 1 & 4,2 \\
Falta de apoio do governo & 1 & 7,7 & 1 & 4,2 \\
Os empregos não-agrícolas são mais atraentes & 2 & 15,4 & 1 & 4,2 \\
\hline Total & 13 & 100 & 24 & 100 \\
\hline
\end{tabular}

Fonte: Pesquisa de campo (1998).

Entre as famílias de pluriativos que foram entrevistadas, conforme indicado no capítulo anterior, também se questionou sobre as motivações que conduziram o jovem a abandonar a agricultura, pois neste caso os membros da família já estavam inseridos em alguma atividade não-agrícola. Nesse caso, a hipótese mencionada anteriormente reaparece em sua plenitude. Para as famílias pluriativas gaúchas, em $46 \%$ do casos, os jovens afirmaram ter deixado a agricultura por motivos econômicos, pois as rendas eram muito baixas, se- 
guido de outros $23 \%$ que declararam que os jovens saem devido aos baixos preços dos produtos agrícolas, o que essencialmente é o mesmo motivo anterior. Em Braço do Sul, 33,3\% do total das famílias que são pluriativas disseram que as rendas baixas constituem-se na principal razão para o abandono da agricultura, proporção superada por apenas por 41,6\% do total de famílias que, inesperadamente, indicaram serem as restrições legais para o desmatamento o principal entrave que justifica o pouco interesse dos jovens na agricultura.

Tabela 42

MOTIVAÇÕES DOS JOVENS PARA CONTINUAR A TRABALHAR $N A$ A GRICULTURA NAS COMUNIDADES SELECIONADAS

\begin{tabular}{|l|cc|cc|}
\hline \multirow{2}{*}{ Motivações dos jovens agricultores } & \multicolumn{2}{|c|}{ RS } & \multicolumn{2}{c|}{ SC } \\
\cline { 2 - 5 } & $\mathrm{n}$ & $\%$ & $\mathrm{n}$ & $\%$ \\
\hline Não existem & - & - & 4 & 30,8 \\
Os filhos não moram na propriedade & 2 & 20,0 & 2 & 15,4 \\
Dificuldade em viver na cidade & 2 & 20,0 & 1 & 7,7 \\
Dificuldade em ir para a cidade & - & - & 1 & 7,7 \\
Não têm filhos & - & - & 1 & 7,7 \\
Ficar junto da família e ajudá-la & 3 & 30,0 & - & - \\
É bom / não têm interesse em outra atividade & 2 & 20,0 & - & - \\
Ganham o suficiente para o sustento & 1 & 10,0 & - & - \\
Sem resposta & - & - & 4 & 30,8 \\
\hline Total & 10 & 100,0 & 13 & 100,0 \\
\hline
\end{tabular}

Fonte: Pesquisa de campo (1998).

Outra hipótese que se buscou averiguar refere-se à relação da pluriatividade com a posse da terra. Os entrevistados foram interrogados acerca de sua atitude frente a uma situação em que fossem contemplados com o acesso a uma propriedade de terra. A ampla maioria dos indivíduos pluriativos gaúchos e catarinenses dificilmente teria motivação para abandonar a atividade não-agrícola em que se encontram empregados e voltar a se dedicar exclusivamente à agricultura e à atividade de administração da propriedade herdada, se uma situação de acesso à terra porventura ocorresse. Dos 29 pluriativos que foram entrevistados, somente um respondeu que voltaria a trabalhar na agricultura, no caso de herança de uma propriedade.

Os indivíduos pluriativos também foram interrogados acerca de sua atitude em caso de demissão ou perda do emprego que ocupavam no momento da entrevista. Também nesta situação, o retorno à atividade agrícola somente foi admitido como uma possibilidade de compensação meramente temporária, sendo esta a 
atitude que tomariam 46,2\% dos pluriativos entrevistados em Padre Eterno Ilges e $25 \%$ dos pluriativos de Braço do Sul, em Blumenau. Mesmo assim, em caso de demissão, a grande maioria dos indivíduos pluriativos (62,1\% em relação ao total de entrevistados) "procuraria imediatamente uma outra ocupação não-agrícola", desconsiderando (ou até mesmo ignorando) a possibilidade de vir a trabalhar na propriedade da família enquanto buscasse outra atividade. Em Blumenau, 68,8\% dos indivíduos pluriativos afirmaram que não voltariam a trabalhar na agricultura mesmo em caso de demissão, ao passo que em Santa Maria do Herval essa proporção diminui para 53,8\%.

Tabela 43

ATITUDEDOS INDIVÍDUOS PLURIATIVOS FRENTE À PERDA DO EMPREGO ATUAL EM ATIVIDADES NÃO-AGRÍCOLAS

\begin{tabular}{|c|c|c|c|}
\hline \multirow{2}{*}{ Atitudes dos pluriativos } & $\mathrm{RS}$ & SC & Total \\
\hline & $\mathrm{n} \%$ & $\mathrm{n} \%$ & $\mathrm{n} \%$ \\
\hline $\begin{array}{l}\text { Imediatamente, voltaria a } \\
\text { trabalhar na agricultura }\end{array}$ & $-\quad-$ & $\begin{array}{ll}1 & 6,3\end{array}$ & 13,4 \\
\hline $\begin{array}{l}\text { Procuraria imediatamente } \\
\text { outro emprego não-agrícola }\end{array}$ & 753,8 & 1168,8 & 1862,1 \\
\hline $\begin{array}{l}\text { Voltaria a trabalhar na agricultura e esperaria } \\
\text { uma oportunidade de trabalho não-agrícola }\end{array}$ & 646,2 & 425,0 & 1034,5 \\
\hline Total & 13100 & 16100 & 29100 \\
\hline
\end{tabular}

Fonte: Pesquisa de campo (1998).

Essa visível falta de atratividade do trabalho agrícola junto aos indivíduos que exercem a pluriatividade pode estar relacionada aos baixos níveis de renda que essa atividade proporciona. Contudo, podem ocorrer outras motivações a estimular a preferência pelas atividades não-agrícolas e a manutenção de condição de pluriativo, como a ampliação do círculo de amizades e o convívio social. Para averiguar a relação da pluriatividade com estes elementos essencialmente subjetivos, os indivíduos pluriativos foram indagados acerca de seus círculos de amizade e sobre o ambiente sociocultural em que exercem seus momentos de lazer e diversão.

Segundo os indivíduos pluriativos entrevistados, o trabalho em uma atividade não-agrícola contribui fortemente para ampliar as suas relações de sociabilidade, especialmente entre aqueles que trabalham em uma mesma indústria. Outro aspecto a ser observado em relação à sociabilidade dos indivíduos que exercem a pluriatividade refere-se às suas preferências matrimoniais. Nas duas comunidades estudadas, verificou-se uma inclinação por parte dos pluri- 
ativos a optar, preferencialmente, por candidatos(as) ao matrimônio que tenham uma profissão diferente da atividade agrícola. No caso dos catarinenses, a preferência por pretendentes cuja profissão fosse diferente da agricultura chegou a 44,4\% do total. Esta proporção, no entanto, ainda é igual à opção dos que afirmaram não levar em consideração a profissão do(a) pretendente como critério para selecionar candidatos ao matrimônio, que no caso dos pluriativos gaúchos foi a opção amplamente predominante $(77,8 \%$ dos respondentes). 


\section{Considerações finais}

A idéia transversal que orienta este livro pode ser descrita como uma tentativa de demonstrar que os processos de transformação das formas de ocupação da força de trabalho, atualmente em curso no meio rural, estão trazendo consigo uma complexidade de alterações sociais, culturais e identitárias que vão muito além das mudanças perceptíveis na performance dos mercados de trabalho. Procurou-se demonstrar que essas alterações vêm contribuindo para o fortalecimento da agricultura familiar, tanto como uma categoria sócio-política como econômico-produtiva. Mas, ao mesmo tempo, também se percebeu que tais transformações implicam em modificações nas formas de funcionamento das unidades familiares, levando ao aparecimento de novas estratégias individuais e coletivas que objetivam garantir a reprodução do grupo enquanto uma família.

Assim, este livro pretende contribuir com as reflexões sobre os temas agrários e a ruralidade brasileira sob o ângulo das formas de ocupação da força de trabalho familiar no meio rural. Procurou-se aportar uma contribuição às discussões recentes sobre as transformações no mercado de trabalho rural, especialmente no que se refere ao crescimento das ocupações não-agrícolas e à diminuição do número de ativos ocupados na atividade agrícolas, vis-à-vis a emergência da pluriatividade. No Brasil, a partir de meados da década de 1990, o estudo das atividades não-agrícolas passou a receber um grande estímulo através do Projeto Rurbano. Segundo dados apurados no âmbito deste projeto, no período de 1981 a 1999 a população rural brasileira de mais de 10 anos de idade não decresceu significativamente, sendo que no período 1992-1999 registrou-se inclusive um pequeno aumento de $0,9 \%$ a.a. Esse comportamento revela um fato novo, pois, desde a década de 1960, os indicadores da dinâmica demográfica da população rural brasileira apontavam, invariavelmente, para sua redução década após década. Os dados do IBGE (apurados pelas PNADs) mostram que desde a década de 1980 a PEA rural brasileira que estava ocupada era composta por cerca de 14 milhões de pessoas, sendo que entre 1992 e 1999 houve um pequeno aumento absoluto, passando de 14,6 para 14,8 milhões de pessoas. 
Por causa dessas alterações demográficas e ocupacionais, alguns estudiosos passaram a olhar com mais cuidado para o espaço rural. Logo perceberam que a relativa estabilização da população ocupada não significava que a agricultura estivesse revertendo uma tendência histórica e conseguindo reter as pessoas nos espaços rurais através da ampliação dos empregos diretos no setor agrícola. Ao contrário, quando os analistas começaram a estudar o perfil da PEA rural brasileira segundo os setores de atividades em que as pessoas estavam ocupadas (agrícola ou nãoagrícola), perceberam claramente que os ativos ocupados na produção agrícola strictu sensu continuavam se reduzindo expressivamente, sobretudo na década de 1990, que registrou uma diminuição de 1,7\% a.a. (passando de 11,1, em 1992, para 10,2 milhões, em 1999) de pessoas ocupadas nas atividades agrícolas. Mas os estudos recentes também demonstraram que a explicação para o fenômeno da estabilização da PEA rural ocupada, nas décadas recentes, está no comportamento das pessoas com domicílio rural ocupadas em atividades não-agrícolas, que aumentaram de 3,06 milhão de pessoas em 1981 para 3,49 em 1992, chegando a 4,62 milhões em 1999. O que representa um aumento de mais de 1,5 milhão de postos de trabalho nas duas décadas.

Em razão dessas transformações estruturais, é cada vez mais aceito entre os estudiosos do mundo rural brasileiro que está em marcha um processo de diferenciação entre a agricultura e o espaço rural. Isto se deve ao fato de que, especialmente a partir da década de 1990, vem-se assistindo no Brasil a um crescimento significativo de pessoas em idade ativa que residem nas áreas rurais mas estão ocupadas em atividades não-agrícolas. Esse fenômeno reforça um clássico argumento dos cientistas sociais que afirmam que além da função de produção de alimentos e matérias-primas o espaço rural também se constitui em um lugar de moradia, de lazer, de identidade cultural, de relação com a natureza, etc.; enfim, um espaço multifuncional.

Contudo, esse crescimento das atividades não-agrícolas não deve ser, imediatamente, associado ao aparecimento da pluriatividade nas famílias rurais. Nesse sentido, procurou-se demonstrar que o crescimento das atividades não-agrícolas no Brasil está relacionado com as alterações nos mercados de trabalho rurais, expressando os novos modos de ocupação da força de trabalho. A pluriatividade, por sua vez, refere-se a um fenômeno que se caracteriza pela combinação das múltiplas inserções ocupacionais das pessoas que pertencem a uma mesma família. Embora não exclusivamente, a pluriatividade é um fenômeno que pode ser observado com maior intensidade entre os agricultores familiares, especialmente naquelas regiões onde essa forma social possui uma história de ocupação do espaço e do território. Por isso, justifica-se e enfatiza-se a necessidade de se estu- 
dar a pluriatividade na perspectiva da agricultura familiar. Isso implica analisar sociologicamente como se dá a articulação entre o contexto social e econômico e as decisões dos indivíduos pertencentes a um grupo familiar. Implica descobrir por que razão algumas famílias que são proprietárias de um pequeno pedaço de terra e trabalham na produção agropecuária, ligadas entre si por laços de parentesco e de consangüinidade, passam a estimular os seus membros a buscar empregos e ocupações não-agrícolas, oferecidas por setores como a indústria da transformação, da construção e a prestação de serviços de toda ordem.

Assim, pode-se afirmar que a emergência da pluriativade ocorre em situações em que os membros que compõem as famílias domiciliadas nos espaços rurais combinam a atividade agrícola com outras formas de ocupação em atividades não-agrícolas. Ou seja, a pluriatividade resulta da interação entre as decisões individuais e familiares com o contexto social e econômico em que estas estão inseridas. Desse modo, a pluriatividade é, ao mesmo tempo, causa e efeito das atividades não-agrícolas. Por isso, insiste-se que não se deve confundir o estudo das atividades não-agrícolas com a análise da pluriatividade, pois esta decorre das decisões e das estratégias dos indivíduos e das famílias rurais que podem ou não optar pela combinação de mais de um tipo de trabalho.

É por essa razão que se acredita que os estudos recentes realizados no Brasil sobre as atividades não-agrícolas acabam associando equivocadamente as alterações que estão ocorrendo nos mercados de trabalho com os processos microssociais que transcorrem a partir das decisões e estratégias dos indivíduos e suas famílias. É preciso considerar que a ampliação das atividades não-agrícolas que está ocorrendo com virtuosidade nos espaços rurais brasileiros pode não implicar um aumento proporcional de famílias pluriativas. Mesmo que a pluriatividade seja dependente da possibilidade de combinação das atividades agrícolas com as não-agrícolas em um determinado contexto social e econômico, é preciso notar que a manutenção das múltiplas inserções ocupacionais depende de um conjunto de variáveis e fatores relacionados à dinâmica das famílias e dos indivíduos que as compõem. Ao não considerar esse aspecto fundamental, muitos analistas acabam afirmando que a pluriatividade é uma característica transitória e efêmera com tendência ao desaparecimento. Os resultados dos estudos de caso apresentados neste livro contradizem essa interpretação, pois demonstram que numa mesma comunidade rural podem ser encontradas famílias pluriativas e não-pluriativas e que tal situação se explica não apenas pelo acesso às ocupações não-agrícolas de uns em detrimento de outros, mas pelas iniciativas, necessidades e decisões que são tomadas pelos indivíduos que as compõem. 
Alguns trabalhos recentes procuraram demonstrar que as atividades nãoagrícolas estariam se desenvolvendo no Brasil como uma espécie de "empregos de refúgio", dada a situação de crise enfrentada pelo setor agrícola no período recente (sobretudo devido ao desemprego crescente e a queda nas rendas agrícolas). $\mathrm{O}$ argumento central que apresentam é o de que o incremento significativo das pessoas domiciliadas em áreas rurais e ocupadas em atividades não-agrícolas estaria relacionado à própria dinâmica da agricultura em uma economia capitalista. A busca de empregos não-agrícolas, sobretudo naquelas regiões onde há possibilidade de inserção em outros setores como os serviços, o comércio e a indústria da transformação, seria uma alternativa para as pessoas que residem no espaço rural e não puderam acompanhar o progresso técnico na agricultura, patrocinado pela modernização iniciada na década de 1970. Nesse sentido, a pluriatividade deveria ser entendida como uma estratégia de sobrevivência de famílias agrícolas mais pobres que têm perdas substanciais de sua renda em função da queda dos preços das principais commodities.

Um outro argumento, que chega as mesmas conclusões embora parta de uma premissa teórica distinta, apoia-se na idéia de que o recurso dos agricultores às atividades não-agrícolas, em geral, decorre da elevação do custo de oportunidade de trabalho e dos efeitos colaterais da própria modernização agrícola, que geraria serviços a montante e a jusante das atividades estritamente agrícolas. Segundo essa perspectiva, o crescimento recente das ocupações não-agrícolas e da pluriatividade das famílias rurais deve ser entendido como uma conseqüência desse processo, já que na década de 1970, devido às características excludentes da modernização técnico-produtiva da agricultura, isso não foi possível. Assim, o crescimento atual das atividades não-agrícolas representaria uma mera chance de sobrevivência, em geral, precária para produtores sem acesso à tecnologia, com terra insuficiente $\mathrm{e}$ crédito escasso. Uma vez reduzidos estes riscos e precariedades, os agricultores que conseguissem consolidar seus sistemas produtivos tenderiam a abandonar, progressivamente, as atividades rurais não-agrícolas e a pluriatividade e voltar-se apenas para a produção agropecuária.

No essencial, essas duas proposições diferem em relação aos aspectos normativos (notadamente, quais políticas públicas deveriam ser implementadas para estimular, para um, ou para reduzir, para outro, a presença das atividades não-agrícolas na estrutura agrária brasileira), derivados do diagnóstico acerca do significado e da natureza das atividades não-agrícolas no Brasil. Sem entrar na discussão dos encaminhamentos propostos por cada perspectiva cabe, contudo, ressaltar que o problema desse tipo de interpretação parece estar na própria compreensão da essência do fenômeno da pluriatividade das famílias rurais. O equívoco consiste em considerar que os agricultores, especialmente 
os familiares, somente recorrem às atividades não-agrícolas devido à precariedade de sua condição social e econômica ou como uma forma de garantir sua sobrevivência. Ou seja, a explicação para a existência da pluriatividade decorre, essencialmente, dos condicionantes macroeconômicos que influenciam e determinam o desenvolvimento capitalista na agricultura. Em nenhum momento confere-se importância, como fator causal, a outros aspectos como a descentralização industrial, a flexibilização dos mercados de trabalho e as novas formas de organização da produção e do consumo. Mais do que isso, não reconhecem a capacidade de interação das próprias famílias e dos indivíduos com as estruturas sociais e as instituições econômicas em que estão inseridos. Os agricultores familiares não são reconhecidos como agentes capazes de prover-se de estratégias e colocar em movimento mecanismos e ações que vão desde a opção por empregos que oferecem melhores rendimentos até ocupações que sejam menos penosas ou que indiquem a segurança de uma aposentadoria segura no futuro.

Em oposição a essas perspectivas, procurou-se demonstrar neste livro como a pluriatividade traduz-se em iniciativas diferenciadas as quais recorrem as famílias de agricultores em diferentes momentos do seu ciclo demográfico. Buscou-se mostrar que a emergência da pluriatividade está fortemente relacionada à dinâmica das economias locais, particularmente das características do mercado de trabalho de atividades não-agrícolas existente em determinado território. Insistiu-se no argumento de que o essencial a ser compreendido é modo como se dá o processo de articulação entre as distintas estratégias adotadas pelas famílias rurais e a dinâmica dos mercados e do contexto social e econômico em que esse processo transcorre. Assim, procurou-se apresentar uma interpretação da pluriatividade, situando-a como uma estratégia deliberada de indivíduos e famílias que buscam viabilizar formas de garantir sua reprodução social. Desse modo, espera-se ter contribuído para demonstrar que uma descrição das alterações recentes que ocorrem nos mercados de trabalho rurais, com destaque para o notável crescimento das atividades não-agrícolas, não é suficiente para se entender os complexos e diferenciados mecanismos que levam uma família a tornar-se pluriativa e como esta condição interfere e conduz à sua viabilidade econômica e produtiva e encaminha a sua reprodução social.

Para chegar a essa compreensão dos fenômenos e processos sociais analisados foi necesssário um lento e persistente amadureciemnto teórico e analítico. O itinerário percorrido lembra os desafios de alguém que, embora conheça o caminho de sua casa, saiba localizar sua residência e o portão de entrada, não consegue ingressar no interior de sua moradia porque lhe falta a chave da porta principal, que lhe facultaria acesso ao ambiente onde tudo é familiar e seguro. Durante o longo período procurou-se por esta "cha- 
ve", que permitisse a análise, sólida e fundamentada, da pluriatividade e suas relações com a agricultura familiar.

Talvez, possa-se considerar que a chave interpretativa esteja em compreender que a pluriatividade não se constitui em fenômeno que decorre, exclusivamente, dos efeitos macroeconômicos do processo de desenvolvimento do capitalismo na agricultura ou de alguma característica intrínseca das diferentes categorias sociais existentes no meio rural como, por exemplo, o tamanho de área de terra disponível ou o grau de absorção do progresso técnico. Pelo contrário, a pluriatividade constituí-se como uma característica social formativa e permanente da estrutura agrária de determinadas regiões agrárias, afetando os mais diversos tipos de unidades produtivas, sejam elas modernizadas ou não, grandes ou pequenas. Mas ela depende, fundamentalmente, do modo como cada família interage com o ambiente social e econômico em que se encontra inserida.

Essa percepção conduziu à idéia de que era necessário concentrar o foco de análise não mais na pluriatividade per se ou na emergência das ocupações e rendas não-agrícolas de modo genérico, mas estudar as relações da pluriatividade com a agricultura familiar. Nesse sentido, buscou-se indicar que as análises sobre a pluriatividade devem ser deslocadas do estudo da dinâmica das atividades agrícolas e não-agrícolas do mercado de trabalho rural para a reflexão sociológica sobre as formas familiares de organização social e econômica. Deve-se observar com particular atenção como as famílias operam e assimilam a combinação de múltiplas ocupações produtivas por parte dos membros que a integram e de que modo essas decisões e iniciativas individuais e coletivas afetam e/ou são influenciadas pelos ambientes rurais onde se verifica a emergência das atividades não-agrícolas.

A partir dessa perspectiva analítica, tornou-se possível retomar uma hipótese desenvolvida em trabalhos anteriores; qual seja, a de que os agricultores familiares podem estabelecer variadas estratégias para garantir sua reprodução social, econômica e cultural que não passam, necessariamente, pela modernização técnico-produtiva de seus sistemas agrícolas e estabelecimentos rurais. Isto é o que ocorre nas regiões da Colônia Velha alemã, no Rio Grande do Sul, e o Vale do Itajaí, em Santa Catarina, onde observou-se um processo de articulação da agricultura familiar com o processo de industrialização difusa, patrocinado pela indústria coureiro-calçadista e têxtil, respectivamente. Essa constatação conduziu a uma interpretação de maior alcance teórico, que indica que a integração dos indivíduos à divisão social do trabalho não caminha em sentido único e, tampouco, é resultante exclusiva das relações econômico-produtivas que se estabelecem em determinada situação. 
Essa verificação permitiu estudar e reavaliar o itinerário que o debate acadêmico brasileiro sobre a agricultura familiar seguiu nas décadas recentes. Percebeu-se que no Brasil as pesquisas sobre esse tema são ainda embrionárias, especialmente no que se refere ao arcabouço analítico preferencial utilizado pelos pesquisadores. No primeiro capítulo do livro analisou-se esse percurso a partir da ótica da sociologia dos estudos rurais e verificou-se que, até a primeira metade da década 1990, não só o debate acadêmico sobre a agricultura familiar estava ausente no caso brasileiro como o próprio reconhecimento social dessa categoria por parte das instituições, dos agentes sociais e das organizações políticas era virtualmente inexistente.

Do ponto de vista da instrumentalização teórica para estudar a pluriatividade e suas relações com as formas familiares faltava, portanto, localizar um enfoque capaz de resgatar os elementos relevantes do debate. $\mathrm{O}$ segundo capítulo, em seu conjunto, reflete essa tentativa, pois nele são resgatadas as contribuições de um inspirado conjunto de autores, que vem reconstruindo, de forma inovadora, a interpretação sobre o desenvolvimento agrário nas sociedades contemporâneas e, em especial, o lugar social da agricultura familiar e das novas formas de trabalho e ocupação. Esses autores propuseram que o estudo da pluriatividade deveria envolver, simultaneamente, uma análise do contexto social e econômico em que se situam os agricultores que as praticam e as motivações familiares e individuais que os inspiram. No geral, concordam que a pluriatividade pode se constituir, ao mesmo tempo, como uma estratégia de reprodução familiar e funcionar como um mecanismo de inserção dos indivíduos na divisão social do trabalho. Assim, ao admitir que a pluriatividade constitui-se em fenômeno que possibilita determinações múltiplas e variáveis, de acordo com as situações concretas e os contextos, as contribuições recolhidas desses autores forneceram importantes pistas de investigação e operacionalização de categorias analíticas.

Além do resgate dessas contribuições, no segundo capítulo também é sugerida a retomada de algumas idéias e noções do modelo proposto por Chayanov, mormente sua indicação de que, no interior das famílias rurais, ocorre um processo de diferenciação que se orienta pelo ciclo demográfico dos membros e, também, de que a família constitui-se em uma unidade que gerencia e conduz os interesses dos indivíduos que a ela pertencem. A partir desse resgate parcial das categorias chayanovianas, propôs-se que a família rural fosse utilizada como unidade de análise pertinente ao estudo da pluriatividade. A utilização da família rural como instrumento heurístico destinado à análise de situações concretas exigiu ainda que fosse estabelecida a separação entre unidade de produção e unidade doméstica, o que permitiu captar as diferenças entre as dinâmicas de funcionamento das unidades familiares pluriativas e de 
agricultores, especialmente no que se refere às formas de alocação de tempo de trabalho entre as atividades agrícolas e não-agrícolas e igualmente com relação à utilização das rendas. Assim, mesmo que apoiando, em um primeiro momento, a interpretação chayanoviana, espera-se ter demonstrado a necessidade de superar sua concepção original no que concerne à indivisibilidade entre trabalho e produção presente nas unidades familiares pois, de fato, esta é uma característica cada vez menos identificável entre os agricultores familiares largamente inseridos nos circuitos mercantilizados, quer seja através das formas de produção ou das formas de alocação da força de trabalho familiar.

Em uma apreciação geral, pode-se dizer que a discussão teórica apresentada nos dois capítulos iniciais não responde apenas às necessidades específicas para a interpretação do fenômeno da pluriatividade. Na verdade, devido às escassas análises e discussões sobre a pluriatividade, produzidas até o presente no Brasil, pretendeu-se com este esforço de análise da literatura internacional contribuir para legitimar academicamente esse objeto de estudo e, em sentido mais amplo, colaborar para que os temas rurais e agrários retomem seu espaço no âmbito das Ciências Sociais brasileiras, especialmente no que se refere à Sociologia.

Foi seguindo esse raciocínio que, nos capítulos três e quatro, pretendeu-se demonstrar, através de várias fontes de informação, que a queda do emprego agrícola no meio rural ocorre em quase todos os países, embora essa redução seja praticamente compensada pelo crescimento das ocupações em atividades não-agrícolas no meio rural, com destaque para as atividades de prestação de serviços. Ao contrário do que se poderia inicialmente supor, a ampliação das ocupações não-agrícolas no espaço rural não é um fenômeno exclusivo dos países ricos e desenvolvidos, pois a análise dos dados apresentados permitiu mostrar que esta é uma situação corrente em quase todos os países da América Latina, do Brasil e da região meridional de nosso País. Entre as razões apontadas para o crescimento das atividades não-agrícolas, no caso brasileiro, destacou-se o processo de diferenciação do mercado de trabalho rural, a queda das rendas das atividades agrícolas e os crescentes avanços tecnológicos, em geral poupadores de mão-de-obra.

A partir da construção desse quadro de referência e de evidências empíricas mais abrangentes, foram investigados dois casos de menor abrangência social, as comunidades de Padre Eterno Ilges, no Rio Grande do Sul, e Braço do Sul, em Santa Catarina. No capítulo quatro demonstrou-se que no Rio Grande do Sul a pluriatividade constitui-se em fenômeno mais recente, pois foi a partir do processo de descentralização da indústria coureiro-calçadista, iniciado na década de 1980, que as famílias dos colonos passaram a combinar as atividades agrícolas e não-agrícolas, incrementando a pluriatividade na região da Colônia Velha alemã. Atualmente, essas diferen- 
tes formas de inserção dos membros das famílias rurais ocorre em vários setores econômicos. No caso de Santa Catarina, a combinação das atividades agrícolas e não-agrícolas por parte das famílias rurais é fenômeno bem mais antigo, pois a indústria têxtil, que absorve a maior parte dessa mão-de-obra que mora nas propriedades rurais e trabalha nas fábricas de tecidos e roupas, surgiu na região do Vale do Itajaí ainda na primeira metade do século XX.

Finalmente, no último capítulo colocaram-se em evidência alguns resultados obtidos através de uma pesquisa de campo realizada em 1998 em duas pequenas comunidades rurais das regiões antes mencionadas. A partir do uso da técnica da análise comparada, pôde-se realizar o cotejo entre famílias de agricultores e famílias pluriativas, evidenciando aspectos que distinguem uma unidade da outra em cada uma das comunidades pesquisadas nos dois Estados. Os resultados dessa análise comparativa demonstram que as famílias pluriativas são, no geral, formadas por um número maior de membros com idades inferiores às famílias de agricultores. Em relação à forma de acesso à terra, ao tamanho de área de terra disponível e ao tipo de cultivos praticados, as famílias pluriativas e as famílias de agricultores não se diferenciam. O mesmo já não ocorre em relação à variável monetária, pois as entradas de dinheiro das famílias pluriativas chegam a ser o dobro das famílias de agricultores, cuja principal fonte de renda monetária (84\%) são as aposentadorias rurais. Contudo, $\mathrm{o}$ aspecto mais importante desses resultados a ser salientado e que subscreve a idéia central deste livro, é o fato de que as famílias que são pluriativas (que, portanto, combinam ocupações em atividades agrícolas e não-agrícolas) continuam a operar em sua lógica familiar de reprodução social, pois os membros que buscam trabalhos não-agrícolas continuam a residir no domicílio dos pais, contribuem nas tarefas da propriedade e, não raramente, aportam recursos financeiros para as despesas do estabelecimento agropecuário.

A análise da pluriatividade e da agricultura familiar aqui empreendida não pretende ser conclusiva. Ao contrário, acredita-se que a chave explicativa aqui proposta poderá colaborar para abrir caminhos e lançar novos desafios interpretativos. O estudo da pluriatividade na perspectiva da agricultura familiar é apenas uma das trilhas a serem seguidas pelos estudiosos da ruralidade contemporânea no Brasil, que ainda oferece ilimitados desafios e múltiplas dimensões a serem exploradas. 


\section{Referências bibliográficas}

ABRAMOVAY, R. Paradigmas do capitalismo agrário em questão. São Paulo: Anpocs; Unicamp: Hucitec, 1992.

. Dilemas da União Européia na reforma da Política Agrícola Comum (PAC). São Paulo: USP, Tese de Livre Docência em Economia, 1999.

. Uma nova extensão para a agricultura familiar. In: SEMINÁRIO NACIONAL DE ASSISTÊNCIA TÉCNICA E EXTENSÃO RURAL. Brasília, DF. Anais..., 1997.29p. (Texto para discussão.)

AGLIETTA, M. Regulación y Crisis del Capitalismo. Madrid: Siglo XXI, 1979.

AIDAR,A.C.K.; PEROSA JÚNIOR, R. M. Espaços e limites da empresa capitalista na agricultura. Revista de Economia Política, São Paulo,v.1,n.3, p.17-39, jul./set. 1981.

ALLAIRE, G.; BOYER, R. La Grand Transformation de L'Agriculture. Paris: INRA/ Economica, 1995.

ALMEIDA, M.W.B. Redescobrindo a família rural. Revista Brasileira de Ciências Sociais, São Paulo, n.1, v.1, p. 66-84, 1986.

ANJOS, F. S. Agricultura familiar em transformação: os colonos-operários de Massaranduba (SC). Pelotas: UFPEL, 1995.

_ _ _ . Agricultura familiar, pluriatividade y desarrollo rural en el Sur de Brasil. Revista Internacional de Sociologia (RIS), n.28, Enero-Aril, 2001a, p.173-205.

Pluriatividade e ruraldade: enigmas e falsos dilemas. Estudos Sociedade e Agricultura. Rio de Janeiro, n.17, outubro, 2001b, p. 54-81.

ARKLETON RESEARCH. Cambio Rural en Europa. Colóquio de Montpellier. Programa de Investigaciones sobre las Estruturas Agrarias y la Pluriatividade. Madrid, Ministerio de Agricultura, Pesca y Alimentacion, 1987.

. Adaptation des Ménages Agricoles en Europe Occidentale : Rapport final du Programme de Recherche sur les Structures et la Pluriactivité des Ménages Agricoles. Luxembuourg, Comission Européenne, 1992.

ASESP/CEBRAP. Revisão crítica da produção sociológica voltada para agricultura. São Paulo, 24 e 25 de março de 1983. p.13-82.

BAGNASCO, A.; TRIGLIA, C. La Construction Sociale du Marche: Le défi de la Troisième Italie. Paris, Juillet/Éditions de L'ENS-Cachan, 1993.

BAGNASCO, A. Le Developpement diffus: le modèle Italien. In: SACHS, I. (Dir.). Quelles Villes, Pour Quel Developpement? Paris: PUF, 1996. p.191-213. 
BARBETTA, P. A. Estatística aplicada às Ciências Sociais. Florianópolis: UFSC, 1994.

BARLETT, P. Part-time Farming: saving the farm or saving the life-style? Rural Sociology, Kansas, v.51, n.3, p.289-313, 1986.

BARTHEZ, A. Famille, Travail et Agriculture. Paris: Economica, 1982.

. Familia, Actividad y Pluriatividad en la Agricultura. In: ARKLETON RESEARCH. Cambio Rural en Europa. Colóquio de Montpellier. Madrid, Ministerio de Agricultura, Pesca y Alimentacion, 1987, p. 161-179.

BELL, C.; MACKINNON, N. Research Issues Relating to the Rise of Farm Household Pluriactivity in Western Europe. In: Rural Change in Europe. Arkleton Research, Second Review Meeting, Waldkirchen, 18-21 september, Germany, 1988, p. 119-129.

BERDEGUÉ, J. L.; REARDON, T; ESCOBAR, G. La cresciente importancia del empleo y el ingresso rurales noagricolas. In: ECHEVERRIA, R. G. (Ed.). Desarrollo de las economias rurales. Washington: Banco Interamericano de Desarrollo - BID, 2001.

BITTENCOURT, G.; BIANCHINI, W. A agricultura familiar na região sul do Brasil - Quilombo (SC): um estudo de caso. Curitiba: Consultoria UTF/036-FAO/INCRA, 1995.

BLAN, M. ; BRUN, A. ; DELORD, H. e LACOMBE, P. La Agriculture Française estelle Encore Familliale? In: COULOMB, P. et al. (Dir.). Les Agriculteurs et la Politique. Paris: Fundation National des Sciences Politiques, 1990. p. 310-331.

BONANO, A. et al. (Eds.). From Columbus to ConAgra: the globalization of agriculture and food. Lawrence: University of Kansas Press, 1994.

BOTELHO, F. Considerações sobre a PNAD. Campinas: UNICAMP, Instituto de Economia, 1999.

BOURDIEU, P. À Propos de la Famille Comme Catégorie Réalisée. Actes de la Recherche em Science Sociales, Paris, n.100, dec. 1993 . p.32-36

BRADLEY, T.; LOWE, P. (Eds.). Locality and Rurality: economy and society in rural regions. Norwich, Geo Books, 1984.

BRUN, A. La Famille Comme Unité d'Analyse du Secteur Agricole. Economie Rurale, Paris, n.194, p.3-8, 1989.

BRUN,A.; FULLER, A. Farm Family Pluriactivity in Western Europe. United Kingdow: The Arkleton Research , 1991.

BUTTEL, F. H.; LARSON, O. F.; GILLESPIE, G. W. The Rural Sociology of Agriculture (under the auspices of the Rural Sociological Society). New York: Greenwood Press, 1990.

BUTTEL, F. H.; LARSON, O. W. Political Implications of Multiple Jobholding in U.S. Agriculture: an exploratory analysis. Rural Sociology, Kansas , v.47, n.2, p.272-294, $1982 b$.

BUTTEL, F. H.; NEWBY, H. The Rural Sociology of Advanced Societies: critical perspectives. London: Croom Helm, 1980. 
CAMPANHOLA, C.; GRAZIANO DA SILVA, J. (Orgs.). O novo rural brasileiro. Jaguariúna/SP: Embrapa Meio Ambiente, 2000.4v.

CARNEIRO, M. J. Camponeses, agricultores e pluriatividade. Rio de Janeiro: Contracapa, 1998.

CARNEIRO, M. J. T. Les Paysans de Sept Laux. La Construction d'un Nouvele Ordre Social. Ecole des Hautes Etudes en Sciences Sociales. Paris, 1993. (Tese de doutorado em Antropologia.)

Pluriatividade no campo: o caso francês. Revista Brasileira de Ciências Sociais, São Paulo, v.11, n.32, p.89-105, out.1996a.

Pluriactivité Agricole: l'héterogénéité cachée. Cahiers d'Economie et Sociologie Rurales, Paris, n.38, p.7-36, $1996 \mathrm{~b}$.

Política de desenvolvimento e o "novo rural". In: SEMINÁRIO "O NOVO RURAL BRASILEIRO”. Campinas, 1999.25p. (Trabalho apresentado em evento.)

. Política pública e agricultura familiar: uma leitura do PRONAF. Revista Estudos Sociedade e Agricultura, Rio de Janeiro, n.8, p.70-83, abr.1997.

CAVAZZANI, A.; FULLER, A. International Perspectives on Part-Time Farming: a review. Geojournal, Grait Briatin, v.6, n.4, p.383-390, 1982.

CEPAL. Empleo rural noagricola y pobreza en America Latina: tendencias recientes. Documento de discusión. Santiago, Chile, 2000.

CHAYANOV, A. V. La Organización de la Unidad Economica Campesina. Buenos Aires: Nueva Vision, 1974.

Sobre a teoria dos sistemas econômicos não capitalistas. In: SILVA, J. G., STOLCKE, V. A questão agrária. São Paulo: Brasiliense, 1981.

CONTRERAS, A. J. Límites de la Production Capitalista en la Agricultura. Revista Mexicana de Sociologia, México, v.39, n.3, p.885-899, 1977.

COURLET, C.; SOLANGE, M. Industrie, Territoire et Politiques Publiques. Paris: L'Harmattan, 1994.

COURLET, C. Novas dinâmicas de desenvolvimento e sistemas industriais localizados. Ensaios FEE, Porto Alegre, v.14, n.1, p.9-26, 1993.

jan./fev. 1995.

CROW, G. The Use of the Concept of 'Strategy' in Recent Sociological Literature. Journal of British Sociological Association, London, v.23, n.1, p.1-25, 1989.

DAVIDSON, A. P. Rethinking Household Livelihood Strategies. Research in Rural Sociology and Development, v.5, p.11-28, 1991.

DEL GROSSI, M. E. Evolução das ocupações não agrícolas no meio rural brasileiro: 1981-1995. Campinas, UNICAMP, Instituto de Economia, 1999. 222p. (Tese de Doutorado em Economia) DELGADO, G. C. Agricultura familiar e política agrícola no Brasil: situação atual e perspectivas. In: REYDON, P. R. B. (Org.). Agropecuária e agroindústria no Brasil: ajuste, situação atual e perspectivas. Campinas: UNICAMP, 1995. p.199-235. 
DELGADO, G.C. Agricultura familiar e política agrícola no Brasil: situação atual e perspectivas. In: REYDON, P. R. B. (Org.). Agropecuária e agroindústria no Brasil: ajuste, situação atual e perspectivas. Campinas: Unicamp, 1995. p.199-235. camp, 1985.

Capital financeiro e agricultura no Brasil. São Paulo/Campinas: Ícone/Uni-

DELORD, B.; LACOMBE, P. Dynamique des Structures Agricoles: explotation ou famille? Économie Rurale, Paris, n.199, p.19-25, 1990.

DESER. Diagnóstico do Desenvolvimento Rural de Blumenau. Curitiba: Departamento de Estudos Sócio-Econômicos Rurais, dezembro de 1997. (Relatório técnico, 68p.)

DIRVEN, M. El Empleo Agrícola en America Latina y el Caribe: passado recente y perspectivas. Santiago de Chile: Desarrollo Productivo, CEPAL, 1997. (Documento de trabajo n.43)

. El empleo rural no agrícola. Santiago de Chile: Unidad de Desarrollo Agrícola da CEPAL, 1998. (Texto para discussão.)

D'JANVRY, A. The Agrarian Question and Reformism in Latin America. Baltimore: John Hopkins University Press, 1981.

D'JANVRY, A.; SADOULET, E. La inversión e desarrollo rural es buen negocio. In: ECHEVERRIA, R. G. (Ed.). Desarrollo de las economias rurales. Washington: Banco Interamericano de Desarrollo - BID, 2001.

DJURFELDT, G. Defining and operationaling family farming from a sociological perspective. Sociologia Ruralis, Netherlands, v.36, n.3, p.340-355, 1996.

ECHEVERRIA, R. G. (Ed.). Desarrollo de las economias rurales. Washington: Banco Interamericano de Desarrollo - BID, 2001.

EIZNER, N. Les Paradoxes de l'Agriculture Française. Introdução de Pierre Coulomb. Paris: L'Harmattan, 1985.

EIZNER, N. ; HERVIEU, B. (Dir.). Anciens Paysans, Nouveaux Ouvriers. Paris: Editions L'Harmattan, 1979.

ENNEW, J.; HIRST, P.; TRIBE, H. Peasantry as an Economic Category. Journal of Peasants Studies, London, v.4, n.4, p.295-322, 1977.

ERRINGTON, A.; GASSON, R. Labour Use in the Farm Family Business. Sociologia Ruralis, Netherlands, v.34, n.4, p.293-307, 1994.

FARFÁN, P. V. Distrito de Vila Itoupava: emancipação? Blumenau: Instituto de Pesquisas e Planejamento Urbano de Blumenau, 1991.20 p.

FERNANDES, F. Fundamentos empíricos da explicação sociológica. São Paulo: T.A. Queiroz, 1980.

FONSECA, R. B. A reforma das políticas agrícolas dos países desenvolvidos. Campinas: Unicamp, Instituto de Economia, 1994. (Tese de doutorado em Economia, 136 p.)

FRANKLIN, S. H. The Europen Pesantry: the final phase. London: Methuen, 1969.

FREITAS MARCONDES, J. V.A agricultura em tempo parcial no Estado de São Paulo e a industrialização. Sociologia, São Paulo, v.24, n.1, p.29-40, 1962. 
FRIEDMANN, H. Simple Commodity Production and Wage Labour in the American Plains. Journal of Peasant Studies, London, v.6, n.1, p.71-100, 1978a.

. World Market, State and Family Farm: social bases of household production in the era of wage labour. Comparative Studies in Society and History, Cambridge, v.20, n.4, p.545-586, 1978 b.

Family enterprises in Agriculture: structural limits and political possibilities. In: COX, G., LOWE, P., WINTER, M. Agriculture: people and policies. London: Allen, 1986a.

. The Family Farm and the International Food Regimes. In: SHANIN, T. Peasants and Peasants Societies: selected readings. London: Penguin Books, 1988. p.247258

FULLER, A. M. Part-time Farming and the Farm Family: a note for future research. Sociologia Ruralis, Netherlands, v.23, n.1, p.5-9, 1983.

. Part-Time Farming: the enigmas and the realities. In: SCHWARZWELLER, H. Research in Rural Sociology and Development. Connecticut, Jai Press, 1984.

Introducción. In: ARKLETON RESEARCH. Cambio Rural en Europa. Colóquio de Montpellier. Madrid: Ministerio de Agricultura, Pesca y Alimentacion, 1987.

FULLER, A.; BRUN, A. Social-Economic Aspects of Pluriactivity in Western Europe. In: Rural Change in Europe. Arkleton Research, Second Review Meeting, Waldkirchen, 18-21 september, Germany, p. 147-167, 1988.

FUNDAÇÃO INSTITUTO BRASILEIRO DE GEOGRAFIA E ESTATÍSTICA IBGE. Departamento de Emprego e Rendimento. Pesquisa Nacional por Amostra de Domicílio (PNAD). Rio de Janeiro, 1992 a 1997.

GARCIA JÚNIOR, A. Terra de trabalho. Rio de Janeiro: Paz e Terra, 1983.

. O sul: caminho do roçado. São Paulo: Marco Zero, 1989.

GAROFOLI, G. Industrialização difusa e pequena empresa: o modelo italiano dos anos 70 e 80. Ensaios FEE, Porto Alegre, v.14, n.1, p.49-75, 1993.

GASSON, R. Farm Women in Europe: their need for off farm employment. Sociologia Ruralis: Netherlands, v. 24, n. 3/4, 1984.

. The Economics of Part-time Farming. England: Longman, 1988.

GASSON, R.; ERRINGTON, A. The Farm Family Business. Wallingford: Cab International, 1993.

GERVAIS, M.; JOLLIVET, M. ; TAVERNEIER, Y. La fin de la France Paysan: 1914 à nos jours. In: DUBY. G., WALLON, A. Histoire de la France Rurale. Paris: PointsSeuil, 1977.

GIANNOTTI, J.A. Recepções de Marx. In: Novos Estudos CEBRAP, n.50, mar. 1998, p. 115-125.

GIULIANI, G. M. Neo ruralismo: o novo estilo dos velhos modelos. Revista Brasileira de Ciências Sociais, São Paulo,v.14, n.5, p.55-68, 1991.

GNACARINI, J. C.; MOURA, M. M. Estrutura agrária brasileira: permanência e diversificação de um debate. $B I B$, Rio de Janeiro, n.15, p.5-52, 1983. 
GOODMAN,D.; REDCLIFT,M.From Peasant to Proletarian. Oxford: Basil Blackwell, 1981.

La Agricultura de Europa Occidental en Transición: la produción simples y el desarrollo del capitalismo. Agricultura y Sociedad, Madrid, n.43, 1987.

. The International Farm Crises. London: Macmillan Press, 1989.

. Refashionig Nature. Food, Ecology and Culture. London: Routledge, 1991.

GOODMAN, D.; SORJ, B.; WILKINSON, J. Agroindústria, políticas e estruturas sociais rurais. Revista de Economia Política, São Paulo, v.5, n.4, p.31-55, out./dez. 1985.

___. Da lavoura as biotecnologias. Rio de Janeiro: Campus, 1990.

GOODMAN, D.; WATTS, M. Reconfiguring the rural or fording the divide?: capitalist restructuring and the global agro-food system. Journal of Peasants Studies, London, v.22, n.1, p.1-49, oct. 1994.

don: Routledge, 1997

GRANDO, M. Z. Agropecuária do Rio Grande do Sul - 1980-1995: a caminho da eficiência. Porto Alegre: Fundação de Economia e Estatística, Secretaria da Coordenação e Planejamento, 1996. 161p.

GRAZIANO DA SILVA, J. Estrutura agrária e produção de subsistência na agricultura brasileira. São Paulo: Hucitec, 1978. 1996. . A nova dinâmica da agricultura brasileira. Campinas: Editora da Unicamp,

GRAZIANO DA SILVA, J. et al. Meio rural paulista: muito além do agrícola e do agrário. São Paulo em Perspectiva, São Paulo, v.10, n.2, p.60-72, 1996.

GRAZIANO DA SILVA, J. O novo rural brasileiro. Nova Economia, Belo Horizonte, v.7, n.1, p.43-81, 1997.

. O novo rural brasileiro. Campinas: Unicamp, Instituto de Economia, 1999. (Coleção Pesquisas, 1)

. Quem precisa de uma estratégia de desenvolvimento. In: NEAD: José Graziano, Jean Marc e Bianchini debatem "O Brasil rural precisa de uma estratégia de desenvolvimento”. Brasília, MDA/CNDRS/NEAD, 2001.

GRAZIANO DA SILVA, J.; BALSADI., O. V.; DEL GROSSI, M.E.. O emprego rural e a mercantilização do espaço agrário. São Paulo em Perspectiva, São Paulo, v.11, n.2, p.50-64, 1997.

GRAZIANO DA SILVA, J.; DEL GROSSI, M. E. A evolução do emprego não agrícola no meio rural brasileiro. In: XXXV CONGRESSO BRASILEIRO DE ECONOMIA E SOCIOLOGIA RURAL, Anais... Natal, Sober, 1997, p.759-785.

. Evolução da renda nas famílias agrícolas e rurais: Brasil, 1992-1997. São Paulo, 1999. 20 p. (Trabalho apresentado na ANPEC.) 
GUANZIROLI, C.E. et al. Experiências recentes das políticas agrárias no Brasil. In: GUANZIROLI, C.E. et al. Agricultura familiar e reforma agrária no século XXI. Rio de Janeiro: Garamond, 2001.

HARVEY,D. Condição pós-moderna. São Paulo: Loyola, 1993.

HEREDIA, B. A morada da vida: trabalho familiar de pequenos produtores do nordeste do Brasil. Rio de Janeiro: Paz e Terra, 1979.

HERING, M. L. R. Colonização e indústria no Vale do Itajaí: o modelo catarinense de desenvolvimento. Blumenau: Ed. FURB, 1987.

HERVIEU, B. L'Agriculture en Ruptures. Alternatives Economiques, Paris, n.90, p.2830, dec. 1990.

___. Les Champs du Future. Paris: Julliard, 1994.

. Les agricultures. Paris: PUF, 1996a.

HERVIEU, B.; VIARD, J. Au Bonheur des Campagnes (et des provences). Paris: Éditions de l'Aube, 1996c.

HESPANHA, P. Com os pés na terra: práticas fundiárias da população rural portuguesa. Portugal: Afrontamento, 1994.

HOBSBAWM, E. A revolução social: 1945-1990. In: A Era dos extremos. O breve século XX: 1914-1991. São Paulo: Companhia das Letras, 1995.p.282-313

HUSSAIN, A.; TRIBE, K. Marxism and the agrarian question. 2.ed. London: Macmillan Publishing, 1983.2v.

ILGENFRITZ DA SILVA, R.; BRAATZ, R. K Reconversão e reestruturação produtiva na agricultura e na agroindústria para o Mercosul. Brasília: PNUD, 1993. (Projeto BRA/91/014.)

JOLLIVET, M. L'Analyse fonctionnelle-structurelle en question ou la théorie nécessaire. In: JOLLIVET, M.; MENDRAS, H. Les Collectivités Rurales Française. Sociétés Paysannes ou Lutte de Classes au Village? Paris: Librairie Armand Colin, 1974. p.155-230.

. La "Vocation Actuelle" de la Sociologie Rurale. Revue Ruralia, Paris, Association des Ruralistes Français, n.1, p.11-132, 1997.

KAGEYAMA, A. A questão agrária brasileira: interpretações clássicas. Revista Reforma Agrária, Campinas, v.23, n.3, p.5-17, 1993.

. O Sub-Emprego Agrícola nos Anos 90. Campinas: Instituto de Economia da Unicamp, 1997. (Texto para discussão.)

. Pluriatividade e ruralidade: aspectos metodológicos. Economia Aplicada, São Paulo, v.2, n.3, p.515-551, jul./set. 1998.

KAGEYAMA, A.; BERGAMASCO, S. M. P. P. A estrutura de produção no campo em 1980. Revista Perspectivas, São Paulo, v.12/13, p.55-72, 1989/1990.

KASIMIS, C.; PAPADOPOULOS, A. G. Family Farming and Capitalist Development in Greek Agriculture: a critical review or the literature. Sociologia Ruralis, Netherlands, v.37, n.2, p.209-227, 1997.

KAUTSKY, K. A questão agrária. Portugal: Proposta, 1980. 
KENNEY, M. et al. Midwestern Agriculture in U.S. Fordism: from the New Deal to economic reestructuring. Sociologia Ruralis, Netherlands, v.29, n.2, p.131-148, 1989.

KLEIN, E. El Empleo Rural no Agrícola en America Latina. Santiago de Chile: PREALC/CEPAL, 1992. (Documento de trabalho n.364.)

KONDER, L. A derrota da dialética: a recepção da idéias de Marx até o começo dos anos trinta. Rio de Janeiro: Campus, 1988.

LACOMBE, P. La pluriactivité et l'evolution des exploitations agricoles. In: Association des Ruralistes Français. La Pluriactivité dans les Familles Agricoles. Paris, 1984. p. 35-54.

LAMARCHE, H. La Pluriactivité Agricole: une solution pour les agriculteurs marginalisés? In: ASSOCIATION DES RURALISTES FRANÇAIS. La Pluriativité dans les Familles Agricoles. Paris, 1984. p. 195-203.

. Crises et Permanence de L'Exloitation Familiale em France. Sociologie $d u$ Travail, Paris, n.4, p.443-458, 1987.

. (Coord.). A agricultura familiar I: uma realidade multiforme. Campinas: Editora da Unicamp, 1993.

Análise da empresa familiar agrícola ou industrial. In: ASSOCIATION des Ruralistes Français. Le Monde Rural et les Sciences Sociales: omission ou fascination. Tradução de Auro Luís da Silva. Paris, 1994a. XIX Colóquio da Association des Ruralistes Françaises.

$\overline{1994 b}$.

. (Coord.). L'Agriculture Familiale II: du mythe à la realité. Paris: L'Harmattan,

Europe du Nord, Europe du Sud: le chaissé-croisé de la course à l'intensification, In: JOLLIVET, M., EIZNER, N. L'Europe et ses Campagnes. Paris: Fundation National de Sciences Politiques, 1996.

. (Coord.). A agricultura familiar II: do mito à realidade. Campinas: Editora da UNICAMP, 1999.

LEITE, S. A pequena produção e o quadro recente da agricultura brasileira. Revista Perspectivas, São Paulo, v.12/13, p.31-53, 1989/1990.

LÊNIN, I. U. O desenvolvimento do capitalismo na Rússia. São Paulo: Nova Cultural, 1988. (Coleção Os Economistas)

LIPIETZ, A. Miragens e milagres. Rio de Janeiro: Nobel, 1988.

LLAMBI, L. La Economia Politica del Campesinado: apuntes para una nueva agenda teorica de investigación. Estudios Rurales LatinoAmericanos, Bogotá, v.13, n.3, p.209241, mayo/ago. 1990a.

. Transitions to and Within Capitalism: agrarian transitions in Latin America, Sociologia Ruralis, Netherlands, v.30, n.2, p.350-72, 1990 b.

LONG, N.; VAN DER PLOEG, J. D.; CURTIN, C. et al. The Commoditization Debate: labor process, strategy and social network. Netherlands: Agricultural University of Wagening, 1986. 
LOPES, M. R. Os produtores conseguirão pagar as dívidas securitizadas? Agroanalysis, Rio de Janeiro, v.17, n.4, p.10-12, abr. 1996.

LOUREIRO, M. R. Terra, família e capital: formação e expansão da pequena burguesia rural em São Paulo, Petrópolis: Vozes, 1987.

LOVISOLO, H. R. Terra, trabalho e capital: produção familiar e acumulação. Campinas: Editora da Unicamp, 1989.

MANN, S. Agrarian Capitalism in Theory and Practice. Chapel Hill and London: The University of North Carolina Press, 1990.

MANN, S.; DICKINSON, J. Obstacles to the Development of a Capitalist Agriculture. Journal of Peasant Studies, London, v.5, n.4, p.466-481, 1978.

____. Collectivizing Our Thoughts: a reply to Patrick Mooney. Rural Sociology, Kansas, v.52, n.2, p.296-303, 1987a.

____. Obstáculos ao desenvolvimento da agricultura capitalista. Literatura Econômica, São Paulo, v.9, n.1, p.7-26, 1987b.

MARINI, M.; PIERONI, O. Relación entre la Familia y el Entorno Social. Tipología de las Familias Agrícolas en una Zona Marginal (Calabria). In: ARKLETON RESEARCH. Cambio Rural en Europa. Colóquio de Montpellier. Madrid: Ministerio de Agricultura, Pesca y Alimentacion, 1987. p.205-247.

MARSDEN, T. et al. The Reestructuring Process and Economic Centrality in Capitalist Agriculture. Journal of Rural Studies, London, v.2, n.4, p.271-280, 1986a.

MARSDEN, T. Reestructuting Rurality: from order to desorder in agrarian political economy. Sociologia Ruralis, Netherlands, v.29, n.3/4, p.312-317, 1989.

. Towards the Political Economy of Pluriactivity. Journal of Rural Studies, London, v.6, n.4, p.375-382, 1990a.

. Exploring a Rural Sociology for the Fordist Transition: incorporating social relations into economic restructuring. Sociologia Ruralis, Netherlands, v.32, n.2/3, p.209-230, 1992a.

MARSDEN, T. et al. Constructing the Countryside. Oxford: Westview Press, 1993b.

MARSDEN, T. Beyond Agriculture? Regulating the new rural spaces. Journal of Rural Studies, London, v.11, n.3, p.285-296, 1995.

MARSDEN, T.; FLYNN, A. Servicing the City: contested transitions in rural realm. Journal of Rural Studies, London, v.9, n.3, p.201-204, 1993a.

MARSDEN, T.; LOWE, P.; WHATMORE, S. (Eds.). Rural Reestructuring: global process and their responses. London: David Fulton Publishers, 1990b.

MARSDEN, T.; MUNTON, R.; WARD, N. Incorporating social trajectories into uneven agrarian development: farm businesses in upland and lowland Britain. Sociologia Ruralis, Netherlands, v.32, n.4, p.408-430, 1992b.

MARTINS, J. S. Capitalismo e tradicionalismo. São Paulo: Pioneira, 1975.

. (Org.). Introdução crítica à sociologia rural. São Paulo: Hucitec, 1986.

MARX, K. O Capital. O processo global de produção capitalista. Tradução Reginaldo Sant'Anna, São Paulo: Difel, 1890/1982. Livro 3, Cap.47. 
. Theories of Surplus Value. London: Lawrence and Wishart, 1976. v.l.

MATTEI, L. A dinâmica da pluriatividade e das ocupações rurais não agrícolas em Santa Catarina nas décadas de 80 e 90. In: SEMINÁRIO "O NOVO RURAL BRASILEIRO”. Campinas, 1999. (Trabalho apresentado em evento.)

MAZOYER, M.; ROUDART, L. Histoire des Agricultures du Monde. Paris: Seuil, 1997. MENDRAS, H. Sociedades camponesas. Rio de Janeiro: Zahar, 1978.

La Fin des Paysans (suivi d'une refletion sur la fin des paysans vingt ans aprés). Paris: Actes Sud-Babel, 1984a.

MOONEY, P. Toward a Class Analysis of Midwestern Agriculture. Rural Sociology, Kansas, v. 48, n.4, p.563-584, 1983.

. Tempo de trabalho, tempo de produção e desenvolvimento capitalista na agricultura: uma reconsideração da tese de Mann-Dickinson. Literatura Econômica, São Paulo, v.9, n.1, p.27-42, 1987.

. My Own Boss. Class, Rationality and the Family Farm. Boulder and London: Westview Press, 1988.

MORAN, W.; BLUNDEN, G.; GREENWOOD, J. The Role of Family Farming in Agrarian Change. Progress in Human Geography, London, v.17, n.1, p.22-42, 1993.

MORGAN, D. H. J. Strategies and Sociologists: a comment on Crow. Journal of British Sociological Association, London, v.23, n.1, p.25-31, 1989.

MOURA, M. Os herdeiros da terra: parentesco e herança numa área rural. São Paulo: Hucitec, 1978.

MUNTON, R.; MARSDEN, T. Dualism or Diversity in Family Farming? Patterns of occupancy changy in British agriculture. Geoforum, London , v.22, n.1, p.105-117, 1991.

MURDOCH, J.; MARSDEN, T. Reconstituting Rurality. Class, community and power in the development process. London: University College London Press, 1994.

NAKANO, Y.A destruição da renda da terra e da taxa de lucro na agricultura. Revista de Economia Política, São Paulo, v.1, n.3, p.3-15, jul./set. 1981.

NAVARRO, Z. Family-Based Farmers and Mercosur: the "other" integration process. Grassroots Development, Washington, v.20, n.2, p.34-43, 1996.

NEVES, D. Agricultura familiar: questões metodológicas. Revista Reforma Agrária, Campinas, v.25, p.21-37, maio/dez. 1995.

. Agricultura familiar e mercado de trabalho. Revista Estudos Sociedade e Agricultura, Rio de Janeiro, n.8, p.7-25, abr. 1997.

NEWBY, H. Rural Sociology: a trend report. Current Sociology, London v.28, n.1, p.1-141, 1980.

. Presentación: la família y la explotacion agraria. In: ARKLETON RESEARCH. Cambio Rural en Europa. Colóquio de Montpellier. Madrid: Ministerio de Agricultura, Pesca y Alimentacion, 1987. p.155-161.

OLIVEIRA, F. A economia brasileira: a crítica à razão dualista. 6.ed. Petrópolis: Vozes, 1988. 

- OCDE. Indicateurs Territoriaux de l'Emploi: le point sur le développement rural. Paris, 1996.

PFEFFER, M. The Feminization of Production on Part-time Farms in the Federal Republic of Germany. Rural Sociology, Kansas, v.54, n.1, p.60-73, 1989.

PIORE, M.; SABEL, C. The Second Industrial Divide: possibilities for prosperity. New York: Basic Books, 1984.

PORTO, M. S. G.; SIQUEIRA, D. E. A pequena produção no Brasil: entre os conceitos teóricos e as categorias empíricas. Cadernos de Sociologia, PPGS/UFRGS, Porto Alegre, v.6, p. 76-89, 1994.

RAGIN, C.; ZARET, D. Theory and Method in Comparative Research: two Strategies. Social Forces, v.3, n.61, p.731-754, 1983.

RAUD, C. Indústria, território e meio ambiente no Brasil: perspectivas da industrialização descentralizada a partir da análise da experiência catarinense. Florianópolis: Editora da FURB e Editora UFSC, 1999.

REARDON, T.; BERDEGUÉ, J. L.; ESCOBAR, G. Rural nonfarm employment and incomes in Latin America: overview and policy implications. In: World Development. New York: Pergmon, v. 29, n. 3, 2001.

REIS, J. Modos de industrialização, força de trabalho e pequena agricultura. Revista Crítica de Ciências Sociais, Coimbra, n.15/16/17, p.225-260, 1985.

REIS, J.; HESPANHA, P.; PIRES, A. R. et al. How 'Rural' is Agricultural Pluriactivity? Journal of Rural Studies, Great Britain, v.6, n.4, p.395-399, 1990.

ROBERT, M. Sociologie Rurale. Paris: PUF, 1986.

ROCHE, J. A colonização alemã e o Rio Grande do Sul. Porto Alegre: Globo, 1969. 2v.

SARRACENO, E. La Evolución de las Estruturas Agrarias y el Papel de la Pluriatividad en los Processos de Industrialización Antiguos y Actuales. In: ARKLETON RESEARCH. Cambio Rural en Europa. Colóquio de Montpellier. Madrid: Ministerio de Agricultura, Pesca y Alimentacion, 1987.

. Pluriactivite Farm Families in Italy: historical and territorial differences. In: Rural Change in Europe. Arkleton Research, Second Review Meeting, Waldkirchen, 18-21 September, Germany, p. 173-190, 1988.

Alternative Readings of Spatial Differentiation: the rural versus local economy approach in Italy. European Review of Agricultural Economics, v. 4, n.1, p.451-474, 1994a.

. Recent Trends in Rural Development and Their Conceptualization. Journal of Rural Studies, London v.10, n.4, p.321-330, 1994b.

. The Modern Functions of Small Farm Systems : an Italian experience. Sociologia Ruralis, Netherlands, v.34, n.4, p.308-328, 1994c.

SCHNEIDER, S. O desenvolvimento agrícola e as transformações da estrutura agrária nos países do capitalismo avançado: a pluriatividade. Revista Reforma Agrária, Campinas, v.24, n.3, p.106-132, set./dez. 1994a. 
. Os colonos da indústria calçadista: expansão industrial e as transformações da agricultura no Rio Grande do Sul. Campinas: Unicamp, Instituto de Filosofia e Ciências Humanas, Programa de Pós-Graduação em Sociologia, 1994b. (Dissertação de mestrado em Sociologia.).

. As transformações recentes da agricultura familiar no Rio Grande do Sul: o caso da agricultura em tempo-parcial. Ensaios FEE, Porto Alegre, v.16, n.1, p.105-119, 1995.

. Da crise da Sociologia Rural à emergência da Sociologia da Agricultura. Cadernos de Ciência e Tecnologia, Brasília, v.14, n.2, p.225-238, 1997 b.

SCHNEIDER, S.; SCHMITT, C. J. O uso do método comparativo em Ciências Sociais. Cadernos de Sociologia, PPGS/UFRGS, Porto Alegre, v.9 , p.49-87, 1998.

SCHNEIDER, S. Agricultura familiar e industrialização: pluriatividade e descentralização industrial no Rio Grande do Sul. Porto Alegre: Ed. UFRGS, 1999a.

SCHNEIDER, S.; NAVARRO, Z. Emprego agrícola e novas formas de ocupação no Rio Grande do Sul: uma análise a partir dos dados das PNADs de 1981 a 1997. In: CAMPANHOLA, C. e SILVA, J. G. (Orgs.). O Novo rural brasileiro. v.3. Embrapa/ Unicamp, 2000. p.15-48.

SCHNEIDER, S; RADOMSKY, G.W. Evolução demográfica e ocupacional da população rural do Rio Grande do Sul. Ensaios FEE, Porto Alegre, v.23, nº especial, p.669694, 2002.

SCHWARZ, R. Um Seminário de Marx, In: Novos Estudos CEBRAP, n.50, mar.1998, p.99-114.

SERVOLIN, C. L'Absostion de l'agriculture dans le mode de production capitaliste. In: TAVERNIER, Y.; GERVAIS, M.; SERVOLIN, C. L'Univers Politique des Paysans dans la France Contemporaine. Paris: Presses de la Foundation National des Sciences Politiques, 1972.p.41-77.

. L'Agriculture Moderne. Paris: Éditions du Seuil, 1989.

SEYFERTH, G. A colonização alemã no Vale do Itajaí-Mirim. Porto Alegre: Movimento, 1974.

. Camponeses ou operários? O significado da categoria colono numa situação de mudança. Revista do Museu Paulista, São Paulo, v.29, Nova Série, 1984.

.Etnicidade e cidadania: algumas considerações sobre as bases étnicas da mobilização política. Boletim do Museu Nacional, Rio de Janeiro, n.42, p.1-15, 1985a.

Janeiro, n.52, p.1-27, 1985b.

. Aspectos da proletarização do campesinato no Vale do Itajaí (SC): os colonos-operários. In: LOPES, J. S. L (Org.). Cultura e identidade operária: aspectos da cultura da classe trabalhadora. São Paulo: Marco Zero, 1987. p.103-123.

. As contradições da liberdade: análise das representações sobre identidade camponesa. Revista Brasileira de Ciências Sociais, São Paulo, v.18, n.7, p.78-96, 1992.

SMITH, A. La Europe Politique au Miroir Local. Paris: L'Harmattann, 1995. 
SOUZA, M. Atividades não-agrícolas e desenvolvimento rural no Estado do Paraná. Campinas: Unicamp, Faculdade de Engenharia Agrícola, Tese (Doutorado), 2000. 292 p.TAVARES DOS SANTOS, J. V. Os colonos do vinho. São Paulo: Hucitec, 1978.

_ _ _ . Crítica da Sociologia Rural e a construção de uma outra sociologia dos processos sociais agrários. In: XIV ENCONTRO ANUAL DA ANPOCS, Caxambu, 1990. 44p. (Trabalho apresentado em evento.)

TEIXEIRA, V. L. Pluriatividade e agricultura familiar na região serrana do Estado do Rio de Janeiro. Rio de Janeiro, Curso de Pós-Graduação em Desenvolvimento Agrícola, UFRRJ, 1998. (Dissertação de mestrado em Sociedade e Agricultura.)

VAN DER PLOEG, J. D. El Processo de trabajo agricola y la mercantilizacion. In: GUZMAN, E. S. (Ed.). Ecologia, Campesinado y Historia. España: Las Ediciones de la Piqueta, 1992.

. Rural Sociology and the New Agrarian Question: a perspective from the Netherlands. Sociologia Ruralis, Netherlands, v.33, n.2, p.240-260, 1993.

VEIGA, J. E. O desenvolvimento agrícola: uma visão histórica. São Paulo: Hucitec, 1991.

_ _ _. Delimitando a agricultura familiar. Revista Reforma Agrária, Campinas, v.25, p.128-142, maio/dez. 1995.

Agricultura familiar e sustentabilidade. In: XX ENCONTRO ANUAL DA ANPOCS, Caxambu, 1996. 21p. (Trabalho apresentado em evento.)

VERGOPOULOS, K. O capitalismo disforme: o caso da agricultura no capitalismo. In: AMIN, S.; VERGOPOULOS, K. A questão agrária e o capitalismo. Rio de Janeiro: Paz e Terra, 1977.

WAIBEL, L. Princípios da colonização européia no sul do Brasil. Revista Brasileira de Geografia, Rio de Janeiro, v.11, n.2, p.159-217, 1949.

As zonas pioneiras do Brasil. Revista Brasileira de Geografia, Rio de Janeiro, v.17, n.4, p.389-417, 1955.

WANDERLEY, M. N. B. O camponês: um trabalhador para o capital. Cadernos de Difusão de Tecnologia, Brasília, v.1, n.2, p.13-78, 1985.

. A produção familiar na agricultura brasileira: notas preliminares para um estudo comparativo. In: XIV ENCONTRO ANUAL DA ANPOCS, Caxambu, 1990. 15p. (Trabalho apresentado em evento.)

. Le Brésil: exploitation familiale ou latifundium? In: LAMARCHE, H. La Agriculture Familiale. Paris: L'Harmattan, 1994. v.2, p.20-27.

WATSON, W. Strategy, Rationally and Inference: the possibility of symbolic performances. Journal of British Sociological Association, London, v.24, n.3, p.485-498, 1990.

WEBER, F. Le Travail Hors de L'Usine: Bricolage et Double Activite. Cahiers d'Economia et Sociologie Rurales, Paris, n.3, dec. 1986.

Le Travail à-Côté. Etude d'etnographie ouvrière. Paris: INRA; EHESS, 1989.

WELLER, J. El Empleo Rural no Agropecuário en el Istmo Centroamericano. Revista de la Cepal, v.62, p.75-90, ago. 1997. 
WHATMORE, S.; MUNTON, R.; MARSDEN, T. The Rural Restructuring Process: emerging divisions of agriculture property rights. Regional Studies, Great Britain, v.24, n.3,p.235-245, 1990.

WOORTMANN, E. F. Herdeiros, parentes e compadres. São Paulo: Hucitec, 1995. 


\section{Lista de siglas e abreviaturas}

ANPOCS - Associação Nacional de Pós-Graduação e Pesquisa em Ciências Sociais

ARF - Association des Ruralistes Françaises

CAPES - Coordenadoria de Pessoal de Ensino Superior

CEE - Comunidade Econômica Européia

CNJA- Centro Nacional de Jovens Agricultores (França)

CNPq - Conselho Nacional de Desenvolvimento Científico e Tecnológico

CONTAG - Confederação Nacional dos Trabalhadores da Agricultura

CUT - Central Única dos Trabalhadores.

DESER - Departamento de Estudos Sócio-Econômicos Rurais

ECU - Unité Monétaire Européenne

EMATER - Empresa de Assistência Técnica e Extensão Rural

EUROSTAT - Office Statistique des Communautes Europeennes

FAO - Organização das Nações Unidas para Agricultura e Alimentação

FAPERGS - Fundação de Amparo à Pesquisa do Estado do Rio Grande do Sul

FEDER - Fonds Européen de Developpment Régional

FEE - Fundação de Economia e Estatística

FEOGA - Fundo Europeu de Orientação e Garantia Agrícola

FNSEA- Federação Nacional dos Produtores Agrícolas (França)

IBGE - Instituto Brasileiro de Geografia e Estatística

ICMs - Imposto sobre Circulação de Mercadorias

IDH - Índice de Desenvolvimento Humano (ONU)

INCRA - Instituto Nacional de Colonização e Reforma Agrária

INPC - Índice Nacional de Preços ao Consumidor (Brasil)

INRA - Institute Nacional de la Recherche Agronomique (França)

IPI - Imposto sobre Produtos Industrializados

JAC - Juventude Agrícola Cristã (França)

LEADER - Liasions entre Actions de Développement de l'Économie Rurale

MBS - Marge Brute Standard

MERCOSUL - Mercado Comum do Sul da América Latina

MJHFH - Multiple Job Holding Farm Household

MST - Movimento dos Trabalhadores Rurais Sem Terra

OCDE - Organização para Cooperação e Desenvolvimento Econômico

OIT - Organização Internacional do Trabalho

ONGs - Organizações Não-Governamentais

ONU - Organização das Nações Unidas 
PAC - Política Agrícola Comum

PEA - População Economicamente Ativa

PIA - População em Idade Ativa

PIB - Produto Interno Bruto

PNAD - Pesquisa Nacional por Amostra de Domicílios

PRONAF - Programa Nacional de Fortalecimento da Agricultura Familiar

RGA - Recensement Général de l'Agriculture

RS - Rio Grande do Sul

SAU - Superfície Agrícola Útil

SC - Santa Catarina

SPSS - Statistical Package for Social Sciences

UE - União Européia

UEC - Unidade Econômica Camponesa

UFRGS - Universidade Federal do Rio Grande do Sul

UNICAMP - Universidade Estadual de Campinas

USA - United States of America

UTA - Unidade de Trabalho Ano

UTH - Unidades de Trabalho Homem 
Ilustração da capa

Ateliê de Flávio Scholles

BR-116, km. 230 - Travessão, Dois Irmãos, RS

Fone (51) 514-2000

Fotolitos

Cathedral Digital

Rua Luzitana, 45A - Porto Alegre, RS

Fone/Fax (51) 3343-4141

Impressão

Editora Evangraf

Rua Waldomiro Schapke, 77 - Porto Alegre, RS

Fone (51) 3336-0422 e 3336-2466 